\title{
A TAXONOMIC REVISION OF CYRTANDRA (GESNERIACEAE) IN SULAWESI, INDONESIA
}

\section{H. J. Atkins ${ }^{1}$ \& A. Kartonegoro ${ }^{2}$}

Taxonomic evaluation of Cyrtandra (Gesneriaceae) from Sulawesi has resulted in the recognition of 39 species. Of these, four species are described as new here: Cyrtandra balgooyi H.J.Atkins \& Karton., C. flavomaculata H.J.Atkins \& Karton., C. longistamina H.J.Atkins \& Karton. and C. parvicalyx H.J.Atkins \& Karton. Eleven names are lectotypified and three names are placed in synonymy. Provisional conservation assessments suggest that seven of these species are Critically Endangered, six are Endangered, three are Vulnerable, two are Data Deficient and 21 are of Least Concern. Illustrations, distribution maps, and a key to the Cyrtandra species of Sulawesi are presented.

Keywords. Cyrtandra, Gesneriaceae, new species, Southeast Asia, Sulawesi, taxonomy.

Evaluasi taksonomi Cyrtandra (Gesneriaceae) dari Sulawesi menghasilkan pengenalan 39 jenis. Diantara jenis-jenis tersebut, empat jenis dideskripsikan sebagai jenis yang baru disini: Cyrtandra balgooyi H.J.Atkins \& Karton., C. flavomaculata H.J.Atkins \& Karton., C. longistamina H.J.Atkins \& Karton. and C. parvicalyx H.J.Atkins \& Karton. Sebelas nama telah dilektotipifikasikan dan tiga nama ditempatkan dalam sinonim. Penilaian konservasi sementara menyarankan bahwa tujuh dari jenisjenis ini dinyatakan Critically Endangered, enam dinyatakan Endangered, tiga dinyatakan Vulnerable, dua dinyatakan Data Deficient dan 21 sisanya dinyatakan Least Concern. Ilustrasi, peta distribusi dan kunci identifikasi untuk jenis-jenis Cyrtandra dari Sulawesi disajikan.

Kata kunci. Asia Tenggara, Cyrtandra, Gesneriaceae, jenis baru, Sulawesi, taksonomi.

Received 12 August 2020 Accepted 7 April 2021 Published 8 September 2021

\section{Introduction}

Cyrtandra J.R.Forst. \& G.Forst. (family Gesneriaceae, subfamily Didymocarpoideae, tribe Trichosporeae, subtribe Didymocarpinae) is a large genus of c.800 species of herbs, shrubs, climbers, and rarely, trees (Atkins et al., 2013). It is a predominantly Southeast Asian genus with a distribution corresponding to the 'Malesian type' sensu van Balgooy (1971); it is found from the Nicobar Islands in the Indian Ocean, throughout Malesia, in Taiwan and the southern Japanese islands, in northern Australia and east across Polynesia to Hawaii. It is recorded on the Asian continent only as far north as central Thailand, and its centres of diversity in Malesia are New Guinea and Borneo (each with more than 150 species) and the Philippines (with more than 80 species). Approximately 175 species of Cyrtandra are also distributed across the Pacific Basin, with every major archipelago hosting numerous

\footnotetext{
${ }^{1}$ Royal Botanic Garden Edinburgh, 20A Inverleith Row, Edinburgh EH3 5LR, Scotland, UK. E-mail: hatkins@rbge.org.uk.

${ }^{2}$ Research Center for Biology, Indonesian Institute of Sciences (LIPI), Jalan Jakarta-Bogor km 46, Cibinong, West Java 16911, Indonesia.
} 
endemic species (Atkins et al., 2013; Johnson et al., 2017). It is found in the forest understorey from sea level to over $3000 \mathrm{~m}$ in altitude.

Sulawesi is the largest island in the region of Wallacea, one of the most complex biogeographical regions in Southeast Asia (Cannon et al., 2007; Lohman et al., 2011; Gower et al., 2012). It lies at the centre of one of the most geologically complex areas in the world (Hall, 2002, 2012) and is itself of composite origin. Its position at the meeting point of floras of diverse origins, and its complex geology, including some of the largest mafic outcrops in the world (van der Ent et al., 2013), have resulted in a unique flora with high levels of endemism (Poulsen, 2012). However, the flora of Sulawesi remains poorly known. It was identified in 2001 (Frodin, 2001) as being one of the top ten places in the world most in need of floristic work, and plant specimen collection rates on the island are among the lowest in Indonesia (Kessler et al., 2002; Cannon et al., 2007; Middleton et al., 2019).

Of the 70 genera of Gesneriaceae found in Asia, only 11 are known to occur east of Wallace's line (Hilliard \& Burtt, 2002) and all these are present on Sulawesi (Mendum \& Atkins, 2004). The first Cyrtandra species to be published from Sulawesi was $C$. celebica Blume (Blume, 1826). Following an expedition to the island by Reinwardt in 1821, de Vriese described five species (de Vriese, 1856), and Koorders (1898) added another five following his extended trip to northern Sulawesi. Other than a recombination by Burtt (Burtt, 1990), no new names for Sulawesi Cyrtandra were then published for over 100 years (Mendum \& Atkins, 2004). Fieldwork in North Sulawesi, Gorontalo, Central Sulawesi and Southeast Sulawesi in the early 2000s led to publication of a further 23 species (Atkins, 2004; Bone \& Atkins, 2013; Kartonegoro \& Potter, 2014; Kartonegoro et al., 2018). Four new species are described here, bringing the total for the island to 39 .

Despite a significant increase in plant collecting across Sulawesi over the past 25 years, particularly from the under-collected West, South and Southeast Provinces, there remain relatively few collections, and seven species of Cyrtandra from the island have been described from a single collection. This situation is clearly not ideal, but with the real possibility that these taxa may not be collected again for many years or may be lost as a result of habitat destruction, an effort has been made to account for all the diversity present.

We present here the first taxonomic synthesis of collections from across the island and provide a key, descriptions, distribution maps and conservation assessments for all known species, including four new species.

\section{Materials and methods}

The study is based on examination of herbarium specimens, and most of the dimensions and descriptions for vegetative and fruit characters are based on dried material. Floral descriptions and measurements are taken either from flowers preserved in Copenhagen solution (70\% methylated spirit, $28 \%$ distilled water and $2 \%$ glycerol) or dried flowers rehydrated by boiling, following the method of Bridson \& Forman (1999). Specimens from the following herbaria 
were examined: $A, B M, B O, C A N B, E, K, K R B, L, N S W, S$ and WU (herbarium codes follow Thiers et al., continuously updated). All specimens cited have been seen, unless stated otherwise.

The species concept adopted here is a morphological one based on consistent differences between species (McDade, 1995; Middleton, 2009; Poulsen, 2012). As found in other similar studies, c. $80 \%$ of the taxa included here presented few problems in terms of species delimitation (McDade, 1995). However, for a small number of species, particularly the six species that comprise the Cyrtandra engleri group (see further discussion under the description of that species), the task was more challenging. Further information, including population-level data, are required to discern whether these difficulties are the result of incipient speciation, hybridisation or other biological processes. For now, an attempt has been made to recognise the variation present in as consistent a way as possible across the island, based on morphological discontinuities.

Proposals for IUCN conservation categories were made following the IUCN Red List Categories and Criteria and associated guidelines (IUCN, 2012). When more than two collection localities were known for a species, precise geographical coordinates known, or georeferenced place names available, these were used to estimate extent of occurrence (EOO) and area of occupancy (AOO; sensu IUCN criterion B1) in GeoCAT, using a 2 km by $2 \mathrm{~km}$ grid cell (Bachman et al., 2011). Because Sulawesi is underexplored (and Cyrtandra species under-sampled), these calculations are likely to underestimate true EOO and AOO values. However, we feel that their inclusion helps emphasise the urgent need for more extensive surveying across the island to assess threats to these species adequately.

In the lists of Additional specimens examined after the description of each species, the specimens are listed first by province, then by regency, and finally, alphabetically by collector (with the prefixes de and van not treated as part of the surname). The provinces are listed from north to south in the order North Sulawesi, Gorontalo, Central Sulawesi, West Sulawesi, South Sulawesi, Southeast Sulawesi. The regencies are listed alphabetically. In case of more than one collection by the same collector, the specimens are listed in order of collection date. Following Poulsen (2012), all uses of the Dutch 'oe' in place names on herbarium specimen labels have been replaced by ' $u$ ', and also 'dj' by 'j' and 'tj' by 'c'.

Forest types referred to in the Habitat and ecology sections after each species description, and in the conservation assessments, follow the categories identified by Cannon et al. (2007) in their study of forest types and conservation priorities in Sulawesi. These comprise 'Lowland', 0-400 m a.s.I.; 'Hill', 400-850 m a.s.l.; 'Upland', 850-1500 m a.s.l.; 'Montane', 1500-2500 m a.s.l.; and 'Tropalpine', > $2500 \mathrm{~m}$ a.s.l.

In the protologues of the four species described by de Vriese, which are based on the collections and manuscripts of Reinwardt, de Vriese refers to Reinwardt's collections using 'mss' or manuscript numbers. These numbers also appear on the specimens. They are included here in the specimen details and in the ex siccatae to help with the future identification of specimens but are possibly not collection numbers. There is one exception, Cyrtandra 
longirostris, for which the mss number and the number on the specimen do not match. In this case, both numbers are given. All other collection and locality details are the same.

Additional notes on diagnostic characters, taxonomic decision-making and nomenclatural issues are given, when appropriate, after each species description.

\section{Characters and terminology}

\section{Leaves}

The terminology used to describe leaf shape follows Hickey (1979).

There is a very strong tendency throughout the Gesneriaceae for the two leaves of a pair to be unequal in size to some degree (anisophylly). All the different states of anisophylly recognised by Hilliard \& Burtt (2002) in their monograph of Agalmyla Blume are recorded in Sulawesi Cyrtandra (Figure 1). At its most extreme, the reduced leaf is represented by a scale-like structure, only about 10-30 mm long, such as in Cyrtandra boliohutensis Karton. \& H.J.Atkins (Figure 1b). Elsewhere, anisophylly can occur as only a slight difference in the size of the two leaves or as a great reduction in one of them to a miniature condition, with an overall length sometimes as short as $10 \mathrm{~mm}$ but with a clear differentiation into petiole and lamina, such as in Cyrtandra widjajae Karton. Sometimes, one leaf of a pair is apparently completely absent and the leaves 'appear alternate', such as in Cyrtandra bruteliana Koord. and C. gorontaloensis H.J.Atkins, although there is usually some indication of a vestigial structure (Figure 1c).

For leaf venation, two main characters are described: 1 ) the number of lateral or secondary vein pairs, and 2) the visibility of the tertiary venation on herbarium specimens. The number of lateral vein pairs varies in Sulawesi Cyrtandra from three to four pairs in small-leaved species such as $C$. serratifolia H.J.Atkins to up to 25 pairs in $C$. celebica. It

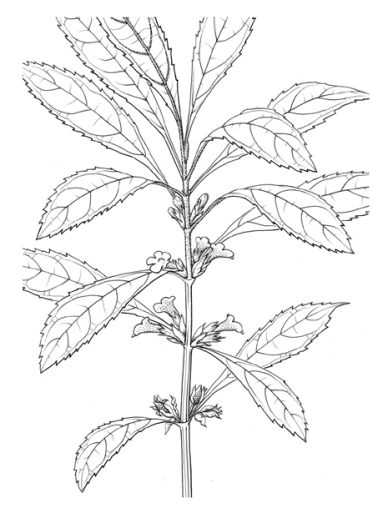

a

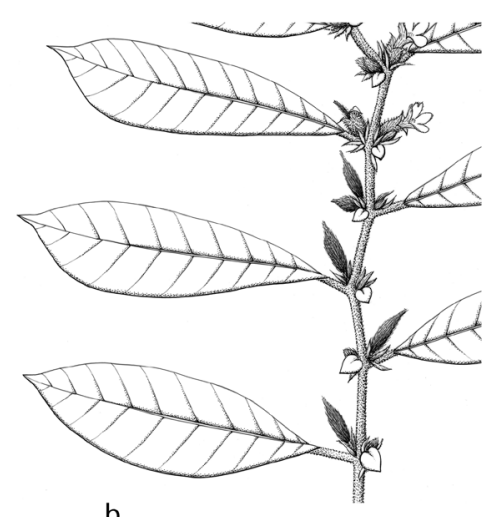

b

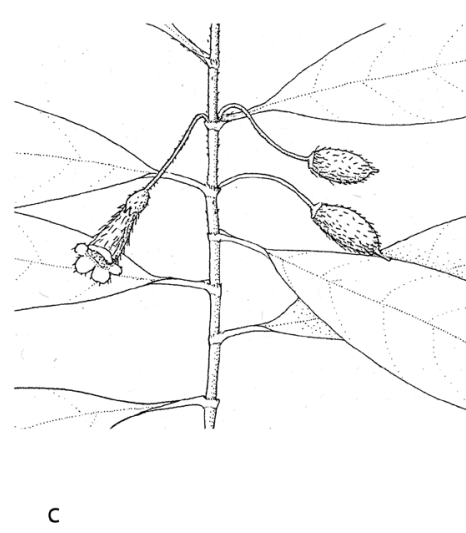

Figure 1. Leaf arrangements in Sulawesi Cyrtandra: $a$, subequal; $b$, anisophyllous with smaller leaf highly reduced but with clear differentiation into petiole and lamina; $c$, leaves 'apparently alternate'. Drawn by Claire Banks ( $a$ and b, modified from Figures 22 and 26) and Christina Oliver (c, modified from Figure 25). 


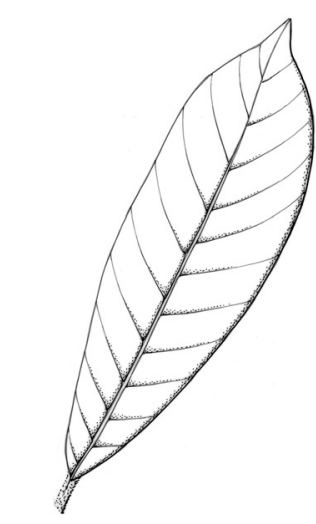

a

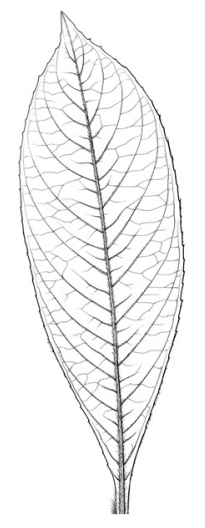

b

Figure 2. Leaf venation in Sulawesi Cyrtandra: a, obscure tertiary venation; $b$, visible tertiary venation. Drawn by Claire Banks, modified from Figures 11 and 22.

usually does not vary significantly within a species, although the widespread Cyrtandra celebica can have between 9 and 25 pairs. For most species in Sulawesi the tertiary venation is easily visible and usually reticulate (Figure $2 b$ ), but there are a few species, including Cyrtandra gambutensis Karton. \& H.J.Atkins and C. purpurea H.J.Atkins, in which it is very faint (Figure 2a). In the majority of specimens, the lateral veins curve upwards before terminating at the margin or looping up to join the vein above. There is a single species, Cyrtandra gorontaloensis, in which the lateral veins run straight out from the midrib and terminate at the margin without looping upwards.

\section{Inflorescence position}

The majority of Cyrtandra species in Sulawesi have axillary inflorescences (Figure 3a), either in the axils of current leaves or at the base of the stem below the leaves, such as in $C$. hendrianii Karton. \& H.J.Atkins and C. polyneura (C.B.Clarke) B.L.Burtt. There are three species, most notably Cyrtandra celebica, with cauliflorous inflorescences (Figure 3c). Four species have trailing inflorescences originating from the base of the plant (Figure 3b): Cyrtandra geocarpa Koord., C. hypogaea Koord., C. Iuteiflora H.J.Atkins and C. rantemarioensis Karton. \& R.E.Bone. The term inflorescence axis is used to describe this trailing structure, because it is not known whether it is an extended peduncle or a modified stem. All four of these trailing species were included in a molecular phylogenetic analysis of Southeast Asian Cyrtandra (Atkins et al., 2020), and it is clear that this phenomenon has evolved more than once in Sulawesi.

\section{Flowers}

Cyrtandra flowers are protandrous; once the anthers have dehisced and the flower moves into the female phase, the stamens recoil back into the corolla tube, pulling the anthers 

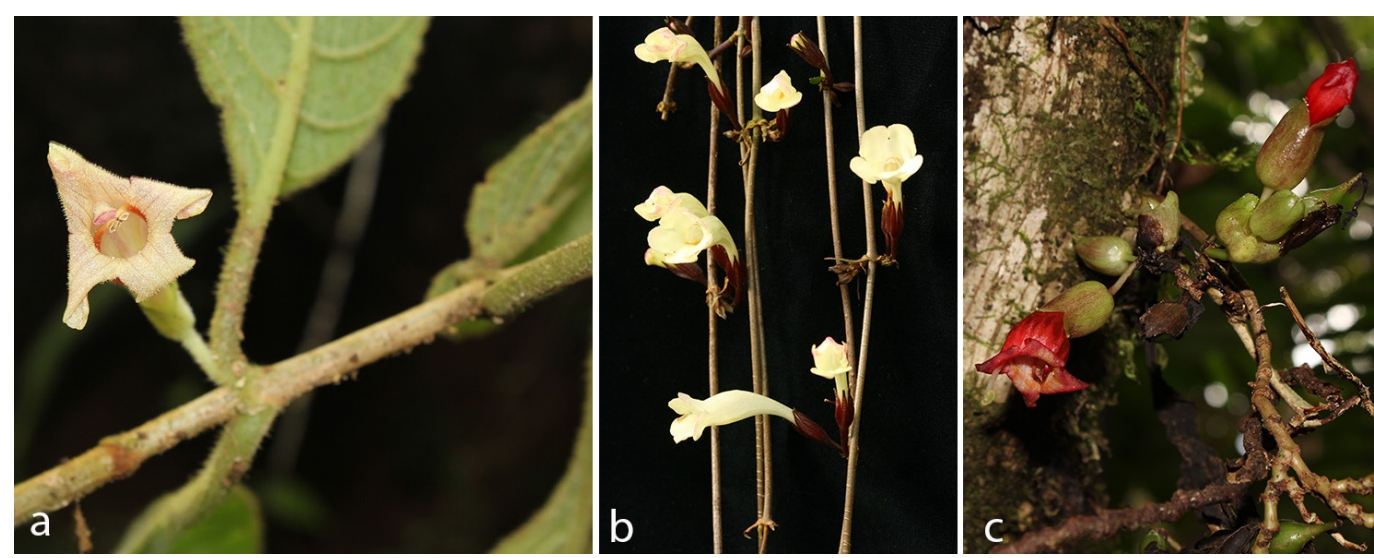

Figure 3. Inflorescence position in Sulawesi Cyrtandra: a, axillary (C. mollis); b, on long trailing stems from the base of the plant (C. Iuteiflora); c, cauliflorous (C. celebica). Photographs: a and c, Sadie Barber; b, Steve Scott.

apart, and the gynoecium extends (visible in Figure 32g,h). Following Bramley et al. (2003), the descriptions and measurements presented here relate to the mature male and female organs and have been taken from a range of flowers whenever possible.

All corollas are bilabiate to a greater or lesser degree, but the corolla limb has two main types: 1) two upper lobes and three lower lobes; and 2) two upper, two lateral and one lower lobe. In the group of species with the first (and most common) type, all lobes are usually 'spreading', that is, not strongly recurved or extending forwards. This morphology is found in many of the Sulawesi species, including Cyrtandra engleri Koord. and C. serratifolia, and is common in the genus as a whole (Figure 4a). In the group of species with the second type, the lower lobe is strongly recurved and the upper and lateral ones either erect and extending forwards or also recurved. There is clearly some variation within this second group in the position of the upper lobes, but it is unclear to what extent the recurvation of these lobes varies with age. All members of this group have, however, the strongly recurved lower lobe. In some, the lower lobe is much longer than the other lobes and resembles a tongue, which is typical of section Glossophorae Schltr. from New Guinea (Schlechter, 1923). In Sulawesi this group includes Cyrtandra longistamina H.J.Atkins \& Karton. and C. purpurea (Figure 4b).

In the descriptions below, dimensions are given for all the lobes and for the corolla. The length of the corolla is measured from the base of the tube to the tip of the upper lobes.

In this taxonomic account, the nectary disc is described as being cupular when it encloses the base of the ovary completely (Figure 5a), and unilateral when the disc is present on only one side of the ovary (Figure $5 b$ ). The distinction is usually very clear, but in a few species, such as Cyrtandra celebica and C. kinhoi Karton. \& H.J.Atkins, the disc encloses the ovary but is much lower on one side than on the other. In these cases it is described as cupular, lower on one side. This is consistent with the terminology used by 


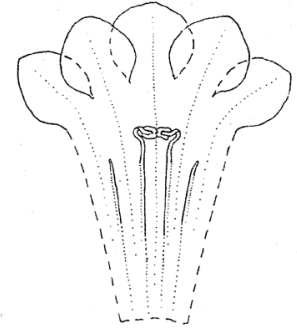

a
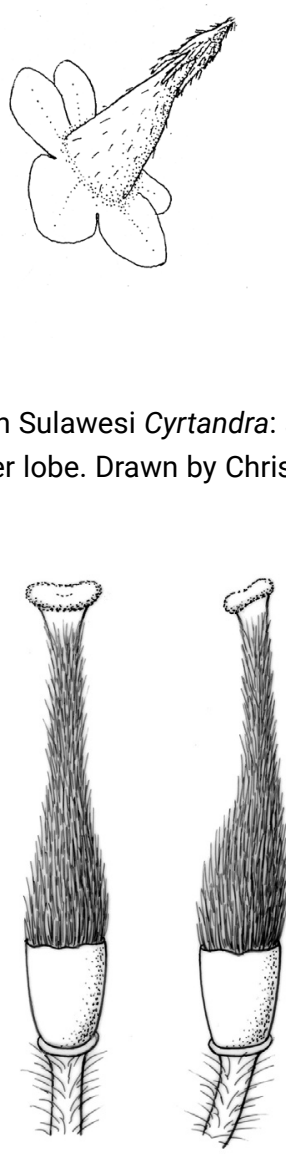

a
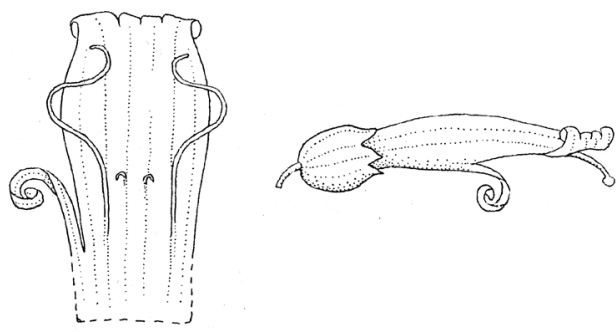

b

Figure 4. Corolla types in Sulawesi Cyrtandra: a, two upper lobes and three lower lobes; b, two upper, two lateral and one lower lobe. Drawn by Christina Oliver, modified from Figures 44 and 52.

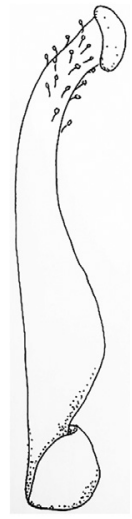

b

Figure 5. Disc types in Sulawesi Cyrtandra: a, cupular; b, unilateral. Drawn by Claire Banks (a, modified from Figure 22) and Hannah Atkins (b).

Burtt (1990). The upper margin of the disc is usually glabrous but can sometimes be fringed with eglandular hairs, as in Cyrtandra gambutensis.

\section{Stigma types}

Three stigma types are seen: bilobed, peltate and capitate (Figure 6). In the species with bilobed stigmas, the lobes are sometimes held upright (Figure 6a) and sometimes horizontal and spreading (Figure 6b). This is recorded in the descriptions, although it probably varies as the flower matures, because both states are observed in some species, such as Cyrtandra kinhoi and C. rubribracteata Karton. \& H.J.Atkins. For the species with horizontally bilobed, 


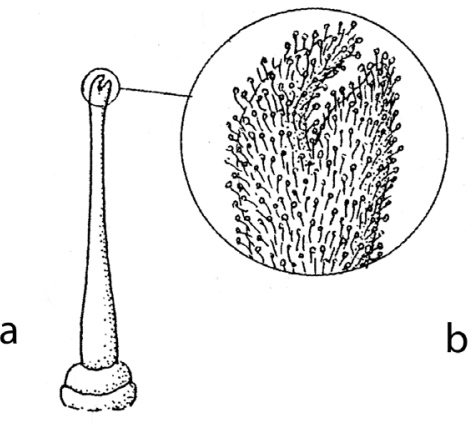

b
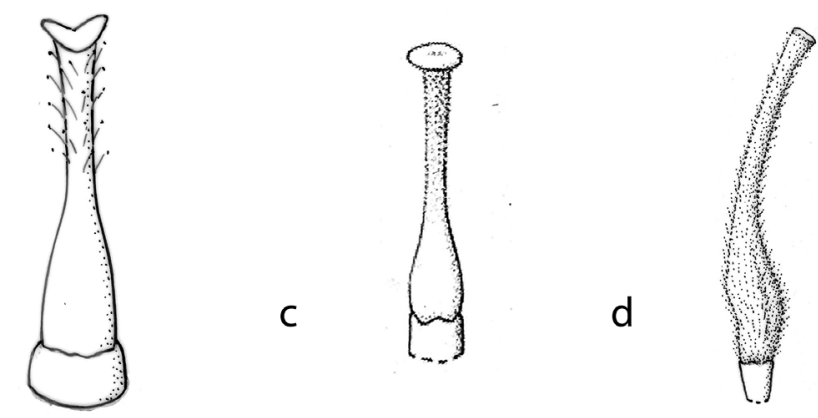

Figure 6. Stigma types in Sulawesi Cyrtandra: a, bilobed, lobes upright; $b$, bilobed, lobes spreading; c, peltate; $d$, capitate. Drawn by Christina Oliver (a, modified from Figure 18) and Claire Banks (b, c and d, modified from Figures 21, 28 and 45).

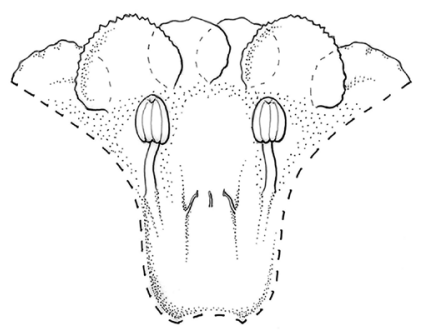

a

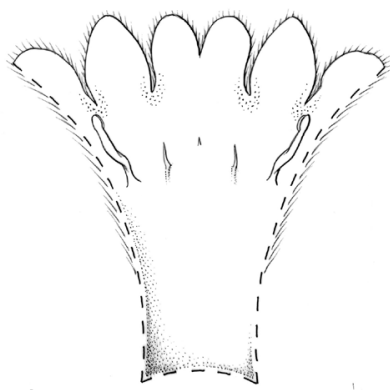

D

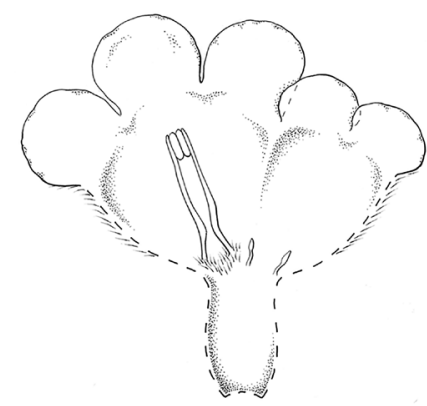

C

Figure 7. Staminodes in Sulawesi Cyrtandra: a, all staminodes approximately the same length; $b$, central staminode much shorter than the laterals; c, two staminodes only. Drawn by Claire Banks, modified from Figures 22, 26 and 28.

capitate or peltate stigmas, a measurement across the diameter of the exposed stigmatic surface is given. For the species with bilobed stigmas in which the lobes are held vertically, often pressed together, a measurement for the length of a single lobe is given.

There are two fertile stamens and usually three staminodes in Cyrtandra flowers (Figure 7). For the stamens, details of filament length and the distance between the point at which the filaments are attached and the base of the corolla are given. The staminodes can be in one of the following forms: 1) staminodes all approximately the same length (Figure 7a); 2) two lateral staminodes, which are longer, and a third, much-reduced central staminode (Figure 7b); or, more rarely, 3) two lateral staminodes, lacking the third staminode altogether (Figure 7c).

\section{Fruits}

Four main fruit shapes are seen in Sulawesi Cyrtandra (Figure 8). The most common fruit shapes are ovoid (Figure $8 \mathrm{~b}$ ) and oblong (Figure $8 \mathrm{~d}$ ), found in 35 of the species. Two 


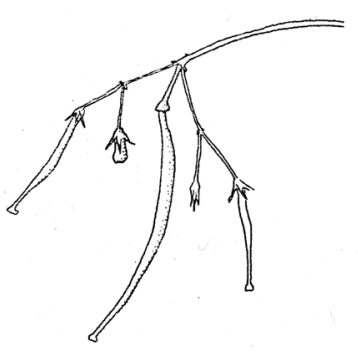

a

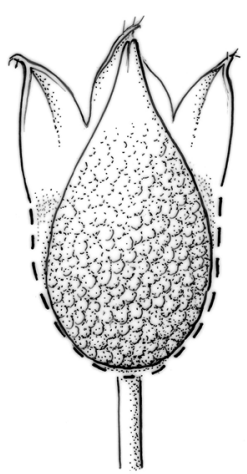

b

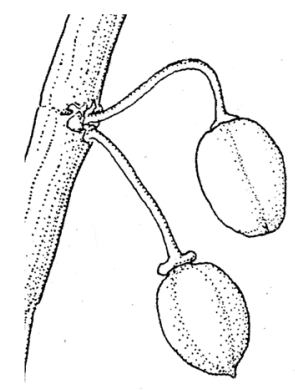

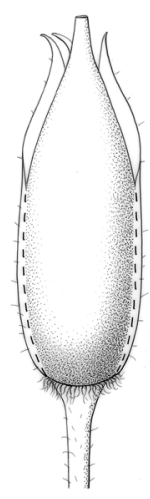

d

Figure 8. Fruit types in Sulawesi Cyrtandra: a, narrowly cylindrical; b, ovoid; c, subglobose; d, oblong. Drawn by Christina Oliver (a and c, modified from Figures 44 and 56) and Claire Banks (b and d, modified from Figures 26 and 28).

species, Cyrtandra multinervis Karton. \& R.Bone and C. tenuicarpa H.J.Atkins, have fruits that are narrowly cylindrical (Figure 8a), a shape much more commonly seen in Borneo (Burtt, 1990). Two other species, Cyrtandra longistamina and C. purpurea, have fruits that are subglobose (Figure $8 \mathrm{c}$ ), a shape more often seen in Pacific and New Guinea species (Schlechter, 1923; Burtt, 2001). Narrowly cylindrical fruits are distinguished from oblong by a ratio of length to width greater than $8: 1$. The persistence of the calyx and base of the style on the mature fruits is also recorded.

\section{Indumentum}

Indumentum on the vegetative parts of the plants, where present, is uniformly eglandular, although it varies in density (Figure 9). On the reproductive structures, however, most notably the ovary, style, and the inside of the corolla lobes, there is variation in the type of indumentum present. The hairs are either eglandular or glandular (Figure 10). The distinction between the two types is usually visible with $a \times 10$ hand lens.

\section{Taxonomic arrangement}

The taxa in this account are listed alphabetically and have not been assigned to the sections used by C. B. Clarke (Clarke, 1883). His sections were established in the nineteenth century and based on a fraction of the diversity of which we are now aware, and furthermore they are not widely used (Burtt, 2001; Bramley, 2003; Clark et al., 2013).

\section{Geography}

Where possible, specimens have been georeferenced and the collection localities mapped. All collections are referred, according to the current provincial boundaries, to North 


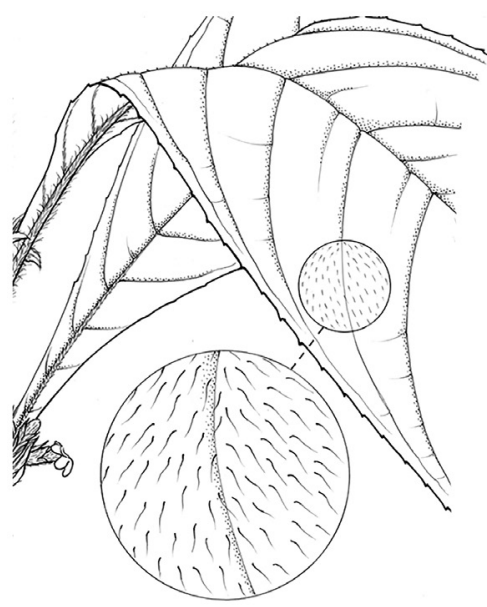

a

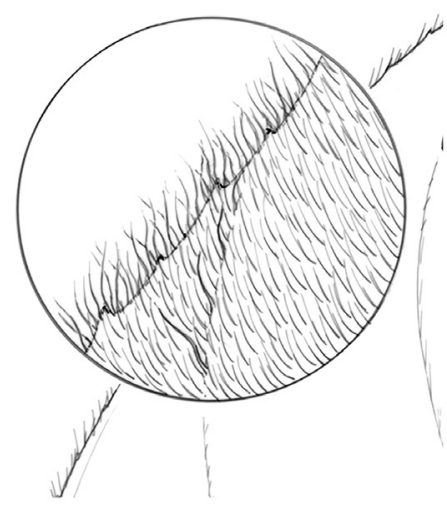

b

Figure 9. Eglandular indumentum on Sulawesi Cyrtandra leaves. Drawn by Claire Banks, modified from Figure 11, this paper, and Figure 2, Olivar et al. (2020).

a

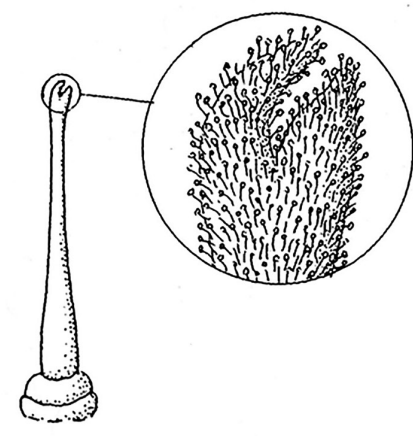

b

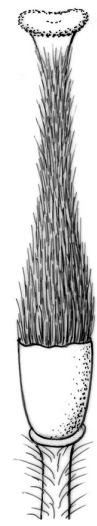

Figure 10. Indumentum types on reproductive structures in Sulawesi Cyrtandra: a, glandular hairs; b, eglandular hairs. Drawn by Christina Oliver (a, modified from Figure 18) and Claire Banks (b, modified from Figure 22).

Sulawesi, Gorontalo, Central Sulawesi, West Sulawesi, South Sulawesi and Southeast Sulawesi.

It is notable that although a few species are widespread in Sulawesi, such as Cyrtandra celebica, $C$. hypogaea and $C$. polyneura, many of the taxa are currently known from only a single province. This is particularly marked in the southern part of South Sulawesi, where from the Latimojong Mountains south, the area appears to have its own distinct Cyrtandra flora. Seven species found here, including Cyrtandra floccosa R.Bone \& H.J.Atkins, $C$. hispidula Karton. \& H.J.Atkins, C. purpureofucata R.Bone \& H.J.Atkins, C. rantemarioensis 
and $C$. sulcata Blume, are recorded only from this province, and many of the widespread species, such as $C$. hypoagaea and $C$. polyneura, are missing.

Increased collecting and analysis of intra-Sulawesi biogeographical patterns in Cyrtandra would allow these patterns to be compared with areas of endemism previously identified in other groups (Evans et al., 2003; Trethowan et al., 2020) to better understand the relationship between species distributions, soils, and the palaeogeographic history of the island (Nugraha \& Hall, 2018; Trethowan et al., 2020). Twenty-six of the Sulawesi taxa have been included in a recent biogeographical study of the genus across Malesia (Atkins et al., 2020), the results of which show that although two species, Cyrtandra boliohutensis and C. polyneura, fall in a predominantly Sunda Shelf clade with species from Borneo and Sumatra, by far the majority of species fall in a clade that contains species from the Philippines, New Guinea and the Pacific, thus suggesting a more Wallacean or eastern affinity to the Sulawesi taxa.

\section{Genus description}

Cyrtandra J.R.Forst. \& G.Forst., Char. Gen. PI. 5 (1776). - Type species: Cyrtandra biflora J.R.Forst. \& G.Forst., designated by St John, 1966.

Whitia Blume, Catalogus 86 (1823). - Type species: Whitia oblongifolia Blume (= C. oblongifolia (Blume) Benth. \& Hook.f. ex C.B.Clarke).

Cyrtandroidea F.Br., Bull. Bernice P. Bishop Mus. 180: 323 (1935). - Type species:

Cyrtandroidea jonesii F.Br. (= Cyrtandra jonesii (F.Br.) G.W.Gillett).

Protocyrtandra Hosok., Trans. Nat. Hist. Soc. Formosa 24: 202 (1934). - Type species:

Protocyrtandra todaiensis (Kaneh.) Hosok. (= C. todaiensis Kaneh.).

The following generic description covers species known from Sulawesi.

Herbs, shrubs, rarely small trees or epiphytic climbers. Stems rounded to angular, hairy (with uniseriate, eglandular hairs) or glabrescent, sometimes woody. Leaves simple; opposite or in threes, sometimes appearing alternate; those of a pair or group subequal, or well developed but somewhat unequal in size, or with one leaf of a pair markedly reduced; petiolate or sessile; glabrous to densely hairy above, often more densely hairy below especially on midrib and veins; leaf bases occasionally markedly oblique, sometimes decurrent or auriculate; margins entire to serrate. Inflorescence axillary, geoflorous or cauliflorous; pedunculate or subsessile; flowers one to numerous. Peduncle with minute to large, sometimes connate, sometimes caducous bracts. Calyx 5-lobed, tube long or short, deciduous or persistent in fruit. Corolla 5-lobed, limb weakly to strongly bilabiate, lobes recurved, spreading, erect or extending forwards, mouth open to strongly compressed laterally, usually white, sometimes yellow, purple, pink or red, sometimes with distinctive markings on lobes and throat. Stamens 2 , filaments borne roughly midway in tube. Staminodes 2 or 3 , borne roughly midway in tube. Disc cupular or unilateral, often persistent around ovary in fruit. Ovary superior, glabrous or 
hairy, unilocular, placentation parietal, placentae recurved, ovules numerous. Style glabrous or hairy. Stigma bilobed, peltate or capitate. Fruit indehiscent, ovoid, subglobose, oblong or narrowly cylindrical, hairy or glabrous, hard-walled or fleshy, often tipped by a persistent style and sometimes with a persistent calyx in fruit. Seeds numerous, ellipsoid.

Distribution. From the Nicobar Islands in the Indian Ocean, throughout Malesia, in Taiwan and the southern Japanese islands, in northern Australia and east across Polynesia to Hawaii.

\section{Key to the Cyrtandra species of Sulawesi}

This key uses both vegetative and floral and fruit characters, although emphasis has been given to vegetative characters wherever possible. A number of species with characters that are variable or difficult to interpret key out in more than one position.

1a. Some or all of the inflorescences trailing from the base of the plant and running along the ground

1b. Inflorescences not trailing from the base of the plant but in the axils of current leaves, at the base of the stem below the leaves, cauliflorous or pendulous from the branches

2a. Leaves narrow ovate to narrow oblong and with 9-25 pairs of lateral veins; corolla glabrous externally 5. C. celebica

2b. Leaves narrow oblong, oblanceolate or narrow obovate and with 4-8 pairs of lateral veins; corolla sparsely hairy to hairy externally 3

3a. Corolla pale yellow; leaves opposite, one of each pair markedly reduced or both well developed but somewhat unequal in size 22. C. luteiflora

3b. Corolla white or red; leaves opposite (or occasionally in threes), those of a pair or group well developed although they may be somewhat unequal in size 4

4a. Trailing inflorescence axis thick (up to $3 \mathrm{~mm}$ in diameter), often branching and appearing 'notched' at the site of old inflorescence bracts; corolla 8-15 mm long; fruits tessellate when dry 16. C. hypogaea

4b. Trailing inflorescence axis slender (1 $\mathrm{mm}$ or less in diameter), usually unbranched, appearing to be smooth; corolla more than $15 \mathrm{~mm}$ long; fruits smooth when dry 5

5a. Corolla red, $15-20 \mathrm{~mm}$ long; inflorescence bracts up to $25 \mathrm{~mm}$ long

30. C. rantemarioensis

5b. Corolla white with yellow and purple markings in throat, over $25 \mathrm{~mm}$ long; inflorescence bracts 1-2 mm long 11. C. geocarpa

6a. Inflorescences pendulous from the branches or cauliflorous 7

6b. Inflorescences in the axils of current leaves or at the base of the stem 
7a. Leaves anisophyllous or appearing alternate; corolla yellow 35. C. spectabilis

7b. Leaves of a pair or group of three well developed if somewhat unequal in size; corolla pale pink or red 8

8a. Leaves oblanceolate to narrow obovate, bases decurrent and with 7-10 pairs of lateral veins 36. C. spicata

8b. Leaves narrow ovate to narrow oblong, bases not decurrent and with 9-25 pairs of lateral veins 5. C. celebica

9a. Most or all of the inflorescences at the base of the stem significantly below the current leaves 10

9b. Inflorescences usually opposite or in the axils of current leaves (fruits may be at the base of the stem below the leaves) 15

10a. Climber or epiphytic shrub; leaf margins entire; fruits subglobose; corolla purple to brown 28. C. purpurea

10b. Non-epiphytic or climbing herb, shrub or small tree; leaf margins not entire; fruits ovoid or oblong; corolla white, yellow, green-yellow, pink or red 11

11a. Leaves with 9 or more lateral vein pairs 12

11b. Leaves with 7 or fewer lateral vein pairs 13

12a. Leaves narrow ovate or narrow oblong, bases not decurrent; corolla red, more or less glabrous externally 5. C. celebica

12b. Leaves narrow obovate, bases decurrent; corolla green-yellow, densely hairy externally

33. C. sandei

13a. Corolla white, tube somewhat flushed pinkish externally, with yellow and purple markings in throat; inflorescence bracts 11-22 mm long; calyx ridged

3. C. boliohutensis

13b. Corolla pale red or yellow; inflorescence bracts 2-4 $\mathrm{mm}$ long; calyx not strongly ridged

14a. Corolla pale red, paler internally; calyx light green; pedicels 5-7 mm long; stigma bilobed 31. C. roseiflora

14b. Corolla yellow; calyx maroon; pedicels $30-40 \mathrm{~mm}$ long; stigma peltate

35. C. spectabilis

15a. Climber or epiphytic shrub 28. C. purpurea

15b. Herb, shrub or small tree 16

16a. Creeping shrub with most leaves less than $3 \mathrm{~cm}$ long 34. C. serratifolia

16b. Herb, shrub or small tree, not creeping, with leaves more than $3 \mathrm{~cm}$ long 17

17a. Corolla bright red 5. C. celebica 
17b. Corolla not bright red; could be white, creamy white, yellow, green-yellow, pink, pale red or purple with or without markings 18

18a. Peduncles long ( $15 \mathrm{~mm}$ or more long) 19

18b. Peduncles short (less than $15 \mathrm{~mm}$ long) or inflorescences sessile (not including pedicels on a 1-flowered specimen; treat as a short peduncle) 22

19a. Inflorescences with large bracts (up to $25 \mathrm{~mm}$ long) 20

19b. Inflorescences with small bracts (less than $5 \mathrm{~mm}$ long) 21

20a. Branching shrub to $4 \mathrm{~m}$; leaves with 17-19 pairs of lateral veins and subentire to minutely and distantly crenulate leaf margin; fruits oblong or narrowly cylindrical, sometimes curved, up to $25 \mathrm{~mm}$ long 24. C. multinervis

20b. Herb or shrub to $1 \mathrm{~m}$; leaves with 7-15 pairs of lateral veins and serrate leaf margin; fruits narrow ovoid to oblong up to $10 \mathrm{~mm}$ long 27. C. polyneura

21a. Peduncles $35-80 \mathrm{~mm}$ long; fruits narrowly cylindrical $(25-35 \times 1.5-2 \mathrm{~mm})$

38. C. tenuicarpa

21b. Peduncles $15-40 \mathrm{~mm}$ long; fruits ovoid $(5 \times 3 \mathrm{~mm})$ 20. C. longirostris

22a. Upper surface of mature leaves with a significant covering of hairs 23

22b. Upper surface of mature leaves glabrous, subglabrous or sparsely hairy 26

23a. Leaves wide elliptic to ovate; inflorescence bracts over $20 \mathrm{~mm}$ long -15 . C. hispidula

23b. Leaves elliptic, narrow elliptic, ovate or narrow oblong; inflorescence bracts $15 \mathrm{~mm}$ or less long 24

24a. Leaves narrow oblong; inflorescence 8- to 10-flowered; corolla 10-12 mm long, white 1. C. albiflora

24b. Leaves narrow elliptic, elliptic or ovate; inflorescence 1- or 2-flowered; corolla 25-40 mm long, not white; can be yellow or reddish 25

25a. Leaves densely hairy above; leaves not drying dark brown or black 23. C. mollis

25 b. Leaves sparsely hairy above; leaves drying dark brown or black 9. C. floccosa

26a. Leaf lamina decurrent (may be only narrowly winged towards base of petiole) or auriculate 27

26b. Leaf lamina not decurrent or auriculate at base 37

27a. Leaf base auriculate 25. C. nitida

27b. Leaf base decurrent (may be only narrowly winged towards base of petiole) 28

28a. Inflorescence bracts linear or narrow ovate (1-3 mm wide) 29

28b. Inflorescence bracts ovate, narrow obovate or oblong-lanceolate, some species with bracts united forming an involucre (5-40 mm wide) 
29a. Corolla less than $20 \mathrm{~mm}$ long; leaves with 17-20 pairs of lateral veins 33. C. sandei

29b. Corolla more than $30 \mathrm{~mm}$ long; leaves with 12 or fewer pairs of lateral veins 30

30a. Corolla white; leaves with 3-5 pairs of lateral veins; stems striate, not scaly

17. C. jellesmanii

30b. Corolla yellow with red stripes on the lobes; leaves with 9-12 pairs of lateral veins; stems tessellate, scaly 7. C. fasciata

31a. Mature leaves less than $5 \mathrm{~cm}$ wide at widest point 32

31b. Mature leaves $5 \mathrm{~cm}$ or wider at widest point 33

32a. Shrub or small tree; leaves over $14 \mathrm{~cm}$ long; inflorescence bracts dull red, c.30 mm long; corolla c.42-45 mm long 32. C. rubribracteata

32b. Herb; leaves less than $8 \mathrm{~cm}$ long; inflorescence bracts green, less than $10 \mathrm{~mm}$ long; corolla c. $15 \mathrm{~mm}$ long 13. C. hekensis

33a. Corolla with lower lip strongly elongated and recurved; calyx white or pinkish; fruits broad-ovoid, almost subglobose 21. C. longistamina

33b. Corolla with lower lip not strongly elongated and recurved; calyx usually green, greenish brown or reddish, sometimes white; fruits narrow ovoid to oblong 34

34a. Inflorescence bracts less than $10 \mathrm{~mm}$ wide 35

34b. Inflorescence bracts $20-25 \mathrm{~mm}$ wide 36

35a. Stems striate; corolla pink, 15-18 mm long 14. C. hendrianii

35b. Stems slightly tessellate; corolla white with yellow markings, over $40 \mathrm{~mm}$ long

8. C. flavomaculata

36a. Herb or shrub to $1 \mathrm{~m}$; calyx less than $10 \mathrm{~mm}$ long, corolla less than $15 \mathrm{~mm}$ long

27. C. polyneura

36b. Shrub or small tree to $7 \mathrm{~m}$; calyx more than $15 \mathrm{~mm}$ long, corolla more than $30 \mathrm{~mm}$ long 18. C. kinhoi

37a. Leaf margins distinctly serrate 38

37b. Leaf margins not distinctly serrate (can be subentire, crenate or serrulate) 48

38a. Mature leaves up to $3 \mathrm{~cm}$ long with 3 or 4 pairs of lateral veins 34. C. serratifolia

$38 \mathrm{~b}$. Mature leaves $4-30 \mathrm{~cm}$ long with 4-14 pairs of lateral veins 39

39a. Inflorescence bracts over $20 \mathrm{~mm}$ long 40

39b. Inflorescence bracts less than $7 \mathrm{~mm}$ long 41

40a. Mature leaves oblong to narrow oblong, $3-5 \mathrm{~cm}$ wide; calyx distinctively ridged

3. C. boliohutensis

40b. Mature leaves wide elliptic to ovate, $9-10 \mathrm{~cm}$ wide; calyx not distinctively ridged 
41a. Corolla pale red or deep pink 42

41b. Corolla white or yellow 43

42a. Corolla narrowly funnel-shaped, lobes not recurved 31. C. roseiflora

42b. Corolla with narrow tube in basal half becoming wider and pouched in apical half, narrowing again at mouth; lobes strongly recurved 29. C. purpureofucata

43a. Leaves opposite, with one of a pair highly reduced or occasionally appearing alternate

43b. Leaves opposite, with both members of a pair well developed but can be slightly unequal in size 46

44a. Pedicels $30-40 \mathrm{~mm}$ long; calyx $20-25 \mathrm{~mm}$ long 35. C. spectabilis 44b. Pedicels up to $10 \mathrm{~mm}$ long; calyx 6-12 $\mathrm{mm}$ long 45

45a. Leaves with more than 7 serrations along each leaf margin 2. C. balgooyi 45b. Leaves with only 4-7 deep serrations along each leaf margin 19. C. kjellbergii

46a. Leaves with 4 or 5 pairs of lateral veins and only 4-7 deep serrations along each leaf margin; some leaf pairs strongly anisophyllous 19. C. kjellbergii

46b. Leaves with 7-14 pairs of lateral veins and with more than 7 serrations along each leaf margin; all leaf pairs subequal 47

47a. Leaves elliptic to ovate, drying dark brown or black; corolla yellow, more than $25 \mathrm{~mm}$ long

9. C. floccosa

47b. Leaves narrow oblong to oblanceolate, not drying dark brown or black; corolla white, less than $20 \mathrm{~mm}$ long 37. C. sulcata

48a. Leaves with 17-19 pairs of lateral veins 24. C. multinervis

48b. Leaves with 4-14 pairs of lateral veins 49

49a. Both leaves of a pair well developed if somewhat unequal in size 50

49b. Leaves usually appearing alternate or with one leaf of a pair highly reduced (very occasionally both leaves of a pair on a predominantly anisophyllous plant may be well developed)

50a. Corolla over $25 \mathrm{~mm}$ long; leaves drying dark brown or black 9. C. floccosa

50b. Corolla less than $20 \mathrm{~mm}$ long; leaves not drying dark brown or black 51

51a. Inflorescences not subsessile; peduncles $15-40 \mathrm{~mm}$ long 20. C. longirostris 51b. Inflorescence subsessile; peduncles 3-4 $\mathrm{mm}$ long 37. C. sulcata

52a. Most leaves over $4 \mathrm{~cm}$ wide at the widest point (up to $6.5 \mathrm{~cm}$ wide); peduncle 5-15 mm long 4. C. bruteliana

52b. Most leaves $4 \mathrm{~cm}$ wide or less at the widest point (1-4 cm wide); inflorescence 
sessile or with peduncle less than $5 \mathrm{~mm}$ long (not including pedicels on a 1-flowered specimen; treat as a short peduncle) 53

53a. Leaves with more than 6 pairs of lateral veins 54

53b. Leaves with 6 or fewer pairs of lateral veins 55

54a. Tertiary venation obscure (on herbarium specimen); corolla white with purple markings, 19-20 mm long 10. C. gambutensis

54b. Tertiary venation easily visible (on herbarium specimen); corolla white, less than $15 \mathrm{~mm}$ long 39. C. widjajae

55a. Calyx short relative to corolla ( $1 / 4$ to $1 / 3$ corolla length), less than $5 \mathrm{~mm}$ long

26. C. parvicalyx

55b. Calyx at least $1 / 2$ corolla length, $7-13 \mathrm{~mm}$ long 56

56a. Pedicels up to $5 \mathrm{~mm}$ long; calyx evenly 5-lobed, $10-13 \mathrm{~mm}$ long; corolla white with purple markings 6. C. engleri

56b. Pedicels (5-)15-30 mm long; calyx with three upper lobes united into a shallowly notched limb, and two lower lobes similarly united, 7-10 mm long; corolla creamy white to pale yellow without markings 12. C. gorontaloensis

\section{Species descriptions}

1. Cyrtandra albiflora Karton. \& H.J.Atkins, Edinburgh J. Bot. 75(2): 174 (2018). - Type: Indonesia, Sulawesi, Central Sulawesi, Sumber Agung, Sungai Spa, 92 m, 24 ii 2004, Hendrian, Newman, Scott, Saleh, \& Supriadi 848 (holotype E, isotype BO). Figure 11.

Shrub to $60 \mathrm{~cm}$ in height. Stems striate, densely villose hairy on young growth, hairs up to $3 \mathrm{~mm}$ long, indumentum less dense on older growth. Leaves opposite, subequal (with occasional whorl of smaller leaves on cultivated plants); petiole c. $2 \mathrm{~cm}$ long, hairy; blades 17-22.5 × 5.1-7.7 cm, narrow oblong, base decurrent, only very narrowly winged near base, margin serrulate, apex acuminate; 9-11 pairs of lateral veins and reticulate tertiary venation, light green and hairy above, appearing whitish and hairy below, most densely so on midrib and veins. Inflorescences axillary, sessile, with c.8-10 flowers at various stages of development; bracts green, caducous, 10-11 $\times 5 \mathrm{~mm}$, linear-lanceolate, hairy on both surfaces, most densely so along margins; bracteoles 6-8 mm long, linear, hairy internally and along margins; pedicels 2-3 mm long, densely hairy. Calyx tubular, green, 5-6 mm long, lower lip 2-lobed, lobes short-acuminate, c. $3 \mathrm{~mm}$ long, upper lip divided very briefly at apex, densely hairy externally. Corolla white, 10-12 mm long, widening gradually to mouth, mouth oblique, upper lobes rounded erect to slightly recurved, $1.5 \times 2 \mathrm{~mm}$, lower and lateral lobes more elongate, spreading to slightly recurved, $3 \times 2.5 \mathrm{~mm}$, hairy externally and with glandular hairs internally, on lobes and in mouth. Stamens with filaments c. $1 \mathrm{~mm}$ long, attached 


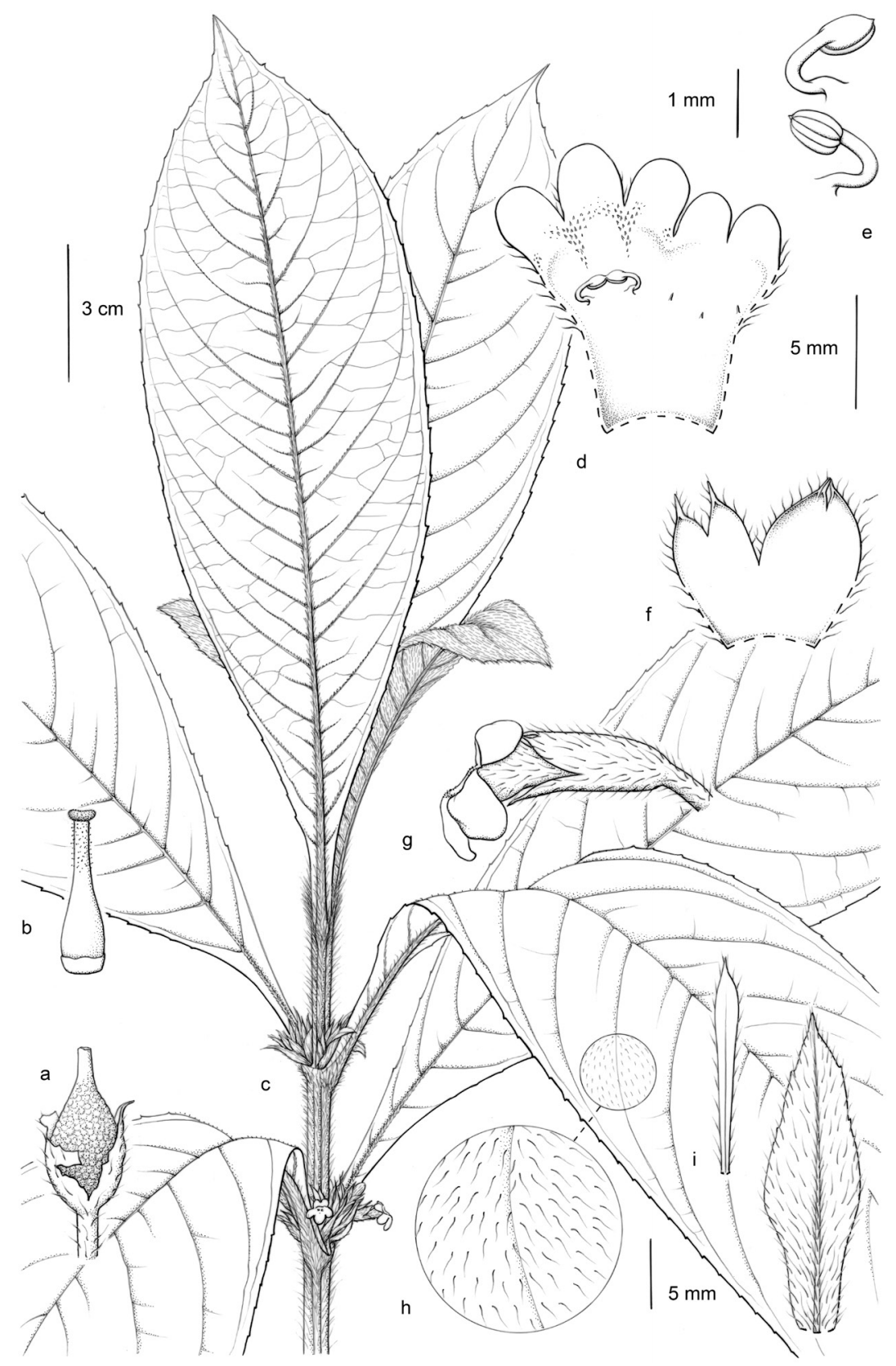

Figure 11. Cyrtandra albiflora. a, Fruit and calyx; b, gynoecium including disc; $c$, habit; $d$, opened corolla, showing position of stamens and staminodes; e, anthers; $f$, opened calyx, showing inner surface; $g$, side view of corolla; $h$, detail of upper leaf surface; i, bracts and bracteoles. Drawn by Claire Banks from Hendrian et al. 848. Reproduced from Kartonegoro et al. (2018) with the permission of the Trustees of the Royal Botanic Garden Edinburgh. 
5-6 mm from base of corolla, glabrous; anthers c. $1 \mathrm{~mm}$ long, glabrous, cohering at apices; staminodes 3 , all less than $0.2 \mathrm{~mm}$ long. Gynoecium 5.5-6 mm long; disc cupular with undulate margin, $1 \mathrm{~mm}$ long, glabrous; ovary glabrous; style glandular hairy; stigma slightly bilobed, lobes small and held upright. Fruits ovoid, drying dark brown, glabrous, verrucose, 5-6 $\times 2-3 \mathrm{~mm}$, base of style and calyx persistent.

Distribution. Central Sulawesi (see Figure 14).

Habitat and ecology. Disturbed lowland forest in a limestone area at an altitude of 92-220 m. Etymology. This species is named for its white flowers (Kartonegoro et al., 2018).

Proposed IUCN conservation category. Cyrtandra albiflora is known from a single mountain from which two collections were made on the same trip in 2004 at altitudes of 92 and $220 \mathrm{~m}$. The lack of specimens precludes estimations of EOO, but the species has an AOO of $8 \mathrm{~km}^{2}$ (Bachman et al., 2011).

According to Cannon et al. (2007), lowland forest is one of the most threatened habitats on the island, and there are no protected areas in this part of Sulawesi (UNEPWCMC \& IUCN, 2019). Until more intensive botanical exploration can be carried out in this area, it is assumed that this species is restricted to the type locality. There is some intact forest on the mountain at higher altitudes, but signs of habitat degradation are present at lower altitudes (UNEP-WCMC \& IUCN, 2019). Because Cyrtandra albiflora is known only from a population on a single mountain in an area without protection and in a habitat that is known to be threatened (Cannon et al., 2007), it is assessed as Critically Endangered (CR), B2ab(iii).

Additional specimen examined. INDONESIA. Central Sulawesi. Banggai: Mt Hek, Sungai Spa, 24 ii 2004, Scott, S. 04-307, grown on at the Royal Botanic Garden Edinburgh (RBGE) as accession 20040645A, vouchered as Scott $509(\mathrm{E})$.

Cyrtandra albiflora is similar to $C$. hendrianii, also from Mount Hek, in being a shrub with subequal, decurrent leaves and many-flowered axillary inflorescences. It can be distinguished, however, by its white corolla (versus pink corolla), green calyx (versus red calyx), densely hairy stems and leaves (versus more or less glabrous stems and leaves), and linear-lanceolate bracts 10-11 mm long (versus oblong-lanceolate bracts 25-35 mm long).

2. Cyrtandra balgooyi H.J.Atkins \& Karton., sp. nov.

Similar to Cyrtandra widjajae Karton. in having strongly anisophyllous leaves and densely hairy calyces, corollas and fruits but differing in leaf margin (serrate in $C$. balgooyi versus subentire in $C$. widjajae), number of lateral vein pairs ( 4 or 5 pairs in $C$. balgooyi versus 8-14 pairs in $C$. widjajae), and corolla length (corolla $20 \mathrm{~mm}$ long in $C$. balgooyi versus corolla 12-15 mm long in C. widjajae). - Type: Indonesia, Central Sulawesi, Danau Tambing, 23 v 1979, van Balgooy 3469 (holotype L; isotypes BO, E). Figure 12. 


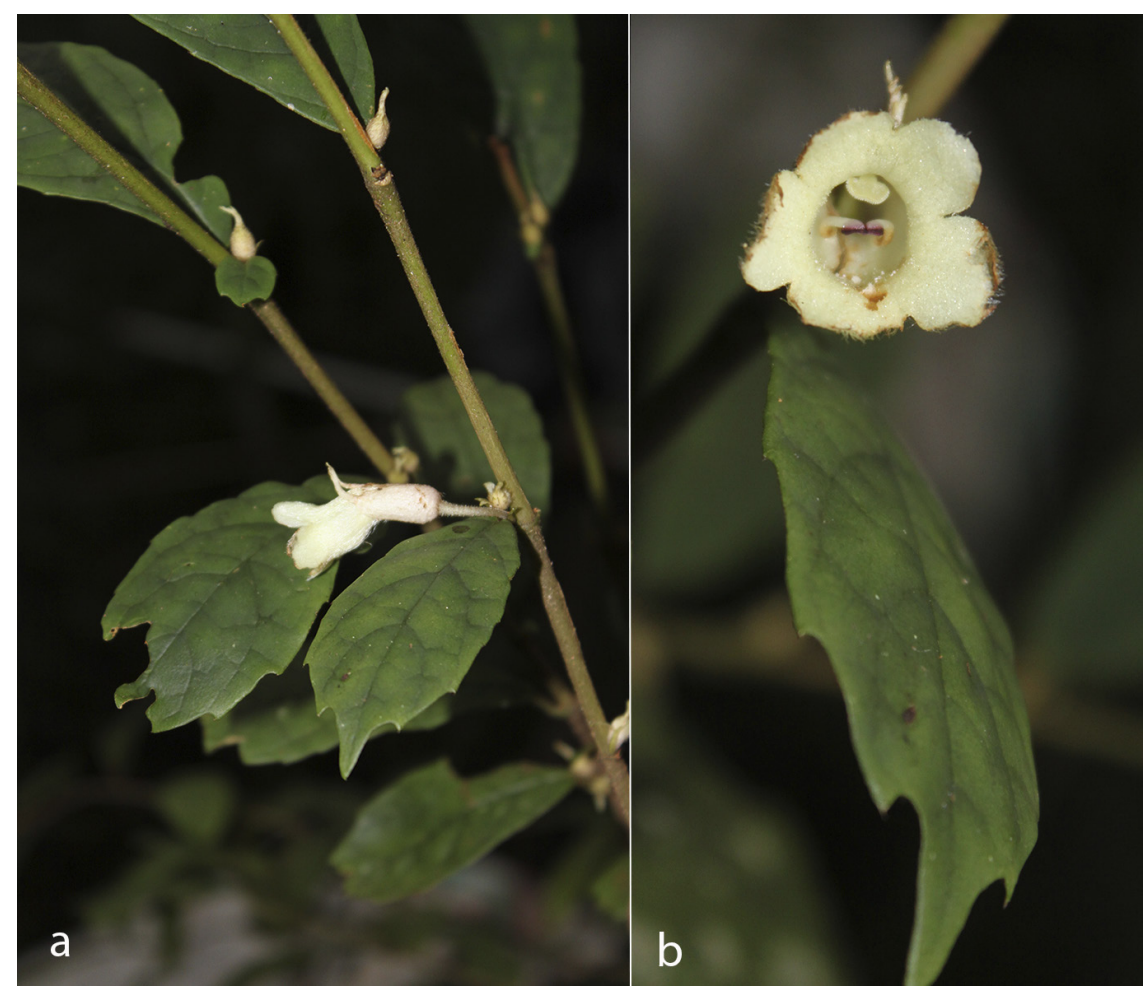

Figure 12. Cyrtandra balgooyi H.J.Atkins \& Karton., sp. nov. a, Stem and side view of flower; b, front view of flower. Photographs: Fabian Brambach. This plant was pressed as Culmsee y2077 (BO, E).

Shrub or small tree to $2.5 \mathrm{~m}$ in height. Stems striate, sparsely hairy, densely coarse-hairy on young growth. Leaves opposite; one leaf of a pair markedly reduced or appearing alternate; petiole 5-6 mm long, hairy; blades of larger leaves $4-7(-8) \times 1.5-2.5(-3) \mathrm{cm}$, elliptic to narrow obovate, base acute, not decurrent, more or less symmetrical, margin coarsely serrate, apex acuminate; 4-5(-6) pairs of lateral veins that loop upwards and join eventually with the vein above with short veins running out to adjacent teeth, tertiary venation reticulate, subglabrous to sparsely hairy above, sparsely hairy below, more densely so on midrib and veins. Reduced leaves 1-5 mm long, cordate or with the blade barely developed. Inflorescences axillary, subsessile, 1- or 2-flowered; peduncle up to $1 \mathrm{~mm}$ long, densely hairy; bracts 1-2 × $1 \mathrm{~mm}$, linear, hairy; pedicels up to $6 \mathrm{~mm}$ long, densely hairy. Calyx very pale green to white, campanulate, 10-12 mm long, more or less evenly 5-lobed or with two sets of lobes tightly adpressed at apices appearing almost 3-lobed, initally enclosing the corolla, lobes subulate, c. $5 \mathrm{~mm}$ long, densely coarse-hairy externally. Corolla creamy white to pale yellow, $20 \mathrm{~mm}$ long, more or less parallel-sided, widening gradually to mouth, lobes spreading not strongly recurved, lobes 3-4 × 3-4 mm, glandular hairy internally at base of lobes, densely eglandular hairy throughout externally. Stamens with filaments $2.5-3 \mathrm{~mm}$ 
long, attached 7-9 $\mathrm{mm}$ from base of corolla; anthers c. $1 \mathrm{~mm}$ long, cohering at apices before dehiscence; staminodes 1-2 mm long. Gynoecium 12-13 mm long; disc cupular with lobed margin, $1 \mathrm{~mm}$ long, glabrous; ovary and style densely eglandular hairy; stigma peltate, slightly bilobed, c. $2 \mathrm{~mm}$ across. Fruits ovoid, densely hairy, $6 \times 4 \mathrm{~mm}$ (immature?), calyx not or partially persistent, base of style persistent.

Distribution. Central Sulawesi (see Figure 14).

Habitat and ecology. Upland and montane forest at an altitude of 1333-2355 m.

Etymology. This species is named after Dr M. M. J. van Balgooy of the Naturalis Biodiversity Center, the Netherlands (L), who has contributed so much to our knowledge of the flora of Southeast Asia and was the collector of the type specimen.

Proposed IUCN conservation category. The EOO of Cyrtandra balgooyi is $444 \mathrm{~km}^{2}$ and the AOO is $20 \mathrm{~km}^{2}$, based on a $2 \times 2 \mathrm{~km}$ grid cell size, under the B criteria (Bachman et al., 2011). Most of the collection localities fall within the boundaries of Lore Lindu National Park (UNEP-WCMC \& IUCN, 2019), which should provide some protection. They are also at relatively high altitude in the slightly less threatened upland and montane forest types (Cannon et al., 2007). This species is assessed as Least Concern (LC).

Additional specimens examined. INDONESIA. Central Sulawesi. Sigi: Mt Nokilalaki, track to shelter 2, 24 vii 2018, Ardi WI225 (KRB); Lore Lindu National Park, Tambing lake, 4 viii 2018, Ardi WI296 (KRB); Summit of Mt Ngilalaki, 9 vii 1939, Bloembergen 3986 (A, BO); Mt Nokilalaki, 6 iii 2008, Cicuzza 787 (E); ibid., 18 iii 2008, Cicuzza 936 (E); Lore Lindu National Park, Uwei Balamba, 21 ii 2011, Culmsee y2077 (BO, E); Sopu Valley, c.80 km from Palu, 29 iv 1979, Hennipman 5110 (A, E, L).

Cyrtandra balgooyi is one of a group of six species that share the characters of strongly anisophyllous leaves, white or light-yellow corollas, and densely hairy calyces, corollas and fruits. The others in the group are Cyrtandra gambutensis, C. gorontaloensis, C. parvicalyx H.J.Atkins \& Karton. and C. widjajae. Cyrtandra balgooyi is currently known only from a small area of Central Sulawesi. The other species in the group from this area is Cyrtandra widjajae, from which this new species can be distinguished most easily by its serrate (as opposed to subentire) leaf margin, smaller number of lateral vein pairs (4 or 5 pairs versus 8-14 pairs) and larger flowers (c.20 mm long versus 12-15 mm long).

Hennipman 5110 has been placed here tentatively, because it has some leaf pairs with subequal leaves and a slightly less serrate margin than that of the other specimens.

3. Cyrtandra boliohutensis Karton. \& H.J.Atkins, Edinburgh J. Bot. 75(2): 178 (2018). Type: Indonesia, Gorontalo Province, Mt Boliohutu, 24 iv 2002, Atkins, Mendum, Newman, Hendrian \& Sofyan 188 (holotype BO; isotypes E, L). Figure 13.

Branching herb to $1 \mathrm{~m}$ in height. Stems slender, striate, sparsely hairy. Leaves opposite, both members of a pair well developed but somewhat unequal in size or with one leaf of a pair 

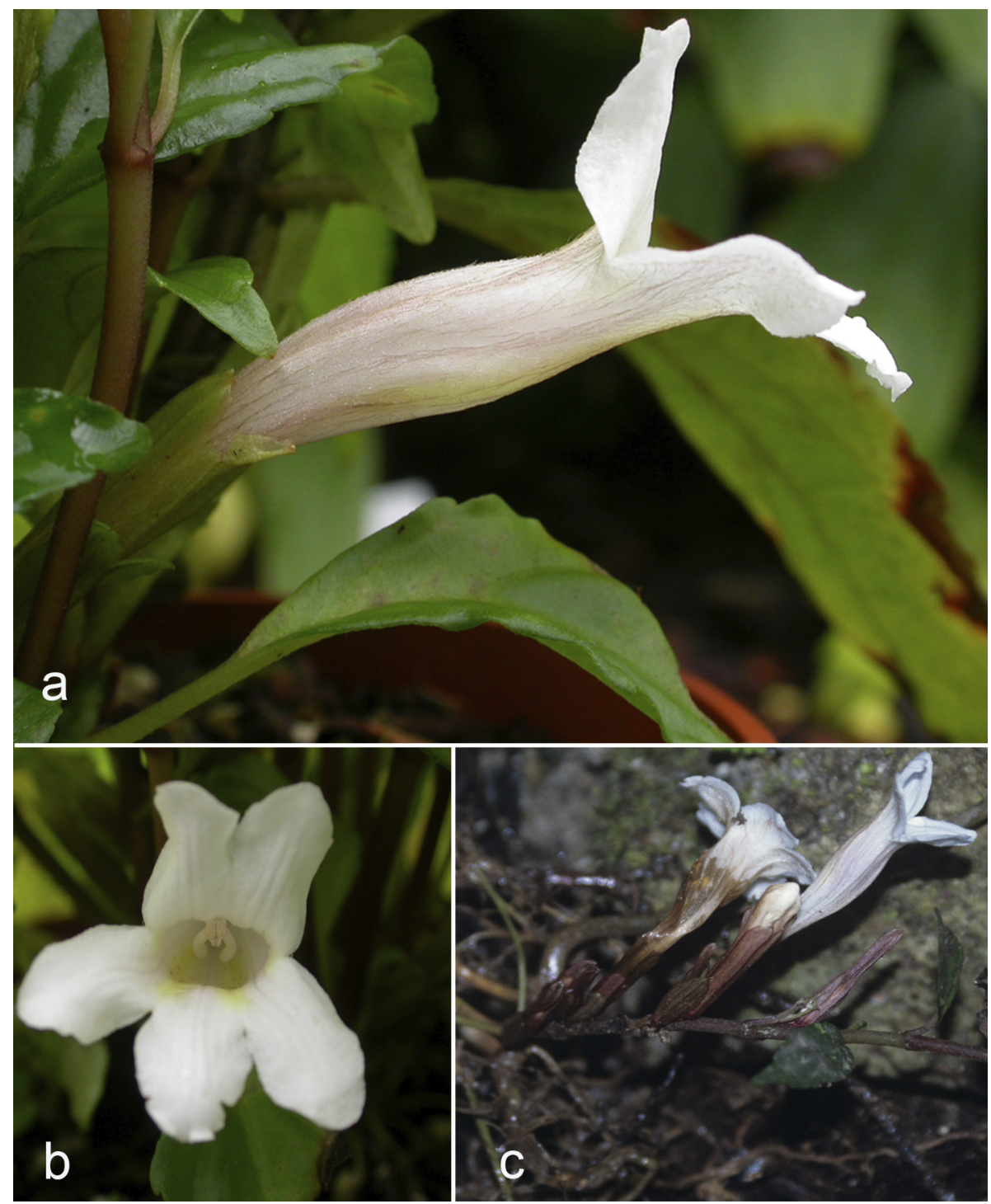

Figure 13. Cyrtandra boliohutensis. a, Side view of flower; $b$, front view of flower; $c$, inflorescence. Photographs: a and b, Steve Scott; c, Hannah Atkins. Reproduced from Kartonegoro et al. (2018) with the permission of the Trustees of the Royal Botanic Garden Edinburgh.

markedly reduced, sometimes appearing alternate; petioles $1.2-2.5 \mathrm{~cm}$ long, hairy; blades 7-14 × 3-5 cm, oblong to narrow oblong, occasionally somewhat rhomboid, base acute, slightly asymmetrical, margin serrate, apex acuminate; 4-6 pairs of lateral veins, curving and running out to margin, subglabrous above, sparsely hairy below, more densely so on midrib and veins. Reduced leaves (where present) 4-5 mm long, scale-like, occasionally 
cordate. Inflorescences subsessile to shortly pedunculate in leaf axils or at base of stems in the axils of fallen leaves, 1- or 2-flowered; peduncle 1-2 mm long, hairy; bracts elliptic or oblong, glabrous, greenish brown, 11-22 ×8-10 mm, partly enclosing calyx at the base, 2-lobed at apex or divided almost to base, sparsely hairy; bracteoles single, oblong, glabrous, green-brown, 10-16 × 5-6 mm; pedicels 2-5 mm long, sparsely hairy. Calyx tubular, ridged, green becoming dark red along ridges, $17-25 \mathrm{~mm}$ long, evenly 5-lobed, lobes c. $2 \mathrm{~mm}$ long, triangular, acuminate at apex, sparsely hairy externally. Corolla white, tube somewhat flushed pinkish externally, yellow in throat with fine, purple spots on the inside of lobes, 35-65 mm long, narrowly funnel-shaped, flattened laterally, brown eglandular hairy externally, lobes spreading not recurved, 9-10 × 5-8 $\mathrm{mm}$. Stamens with filaments 8-12 mm long, attached 20-30 mm above base of corolla; anthers 1.5-3 mm long, coherent at apices, with a fringe of hairs at the base of each anther; staminodes 3, 4-7 mm long. Gynoecium 23-35 mm long; disc cupular with lobed margin, $2 \mathrm{~mm}$ long, glabrous; ovary glabrous; style glabrous at base, eglandular hairy towards stigma; stigma peltate, slightly bilobed, c. $2 \mathrm{~mm}$ across. Fruits oblong to narrow ovoid, green or brown-green, glabrous, verrucose, 10-25 × 2-4 mm; calyx not or only partially persistent, base of style persistent.

Distribution. Gorontalo and Central Sulawesi (Figure 14).

Habitat and ecology. Lowland to upland forest at an altitude of 50-1400 m.

Etymology. This species is named after one of the mountains on which it was first collected (Kartonegoro et al., 2018).

Proposed IUCN conservation category. The EOO of this species is $28,566 \mathrm{~km}^{2}$ and the AOO is $16 \mathrm{~km}^{2}$, based on a $2 \times 2 \mathrm{~km}$ grid cell size, under the B criteria (Bachman et al., 2011). Many of the collection localities are at relatively low altitudes, where the general threat to this habitat type on the island is known to be high (Cannon et al., 2007; Thomas et al., 2011). However, they are all within protected areas: the Nantu Sanctuary Forest, the Mount Sojol Nature Reserve and the Lore Lindu National Park (UNEP-WCMC \& IUCN, 2019). Because all the collection localities fall within protected areas, this species is assessed as Least Concern (LC).

Additional specimens examined. INDONESIA. Gorontalo. Gorontalo: Mt Boliohutu, 320 m, 24 iv 2002, Atkins et al. 190 (BO, E, K, L); ibid., 320 m, 24 iv 2002, Scott, S. 02-126, grown at RBGE as accession 20021906A, vouchered as Scott 505 (E).

Central Sulawesi. Donggala: Mt Sojol, 1400 m, 27 ii 2000, Mendum et al. 00196 (BO, E, L); Parigi Moutong: Pangi Binangga, Uwe lutu, 20 vii 2018, Ardi WI212 (KRB); Sigi: Lore Lindu National Park, Mt Nokilalaki, 24 vii 2018, Ardi WI224 (KRB); Ponoh, 3 km NE of Toro village, 12 xii 2007, Cicuzza 549 (E).

Cyrtandra boliohutensis is morphologically similar to a group of Bornean species, including C. basiflora C.B.Clarke and C. mendumiae Hilliard \& B.L.Burtt, that all have large flowers at the base of the stem, slightly rhomboid leaves and a strongly ridged calyx. It is most easily 


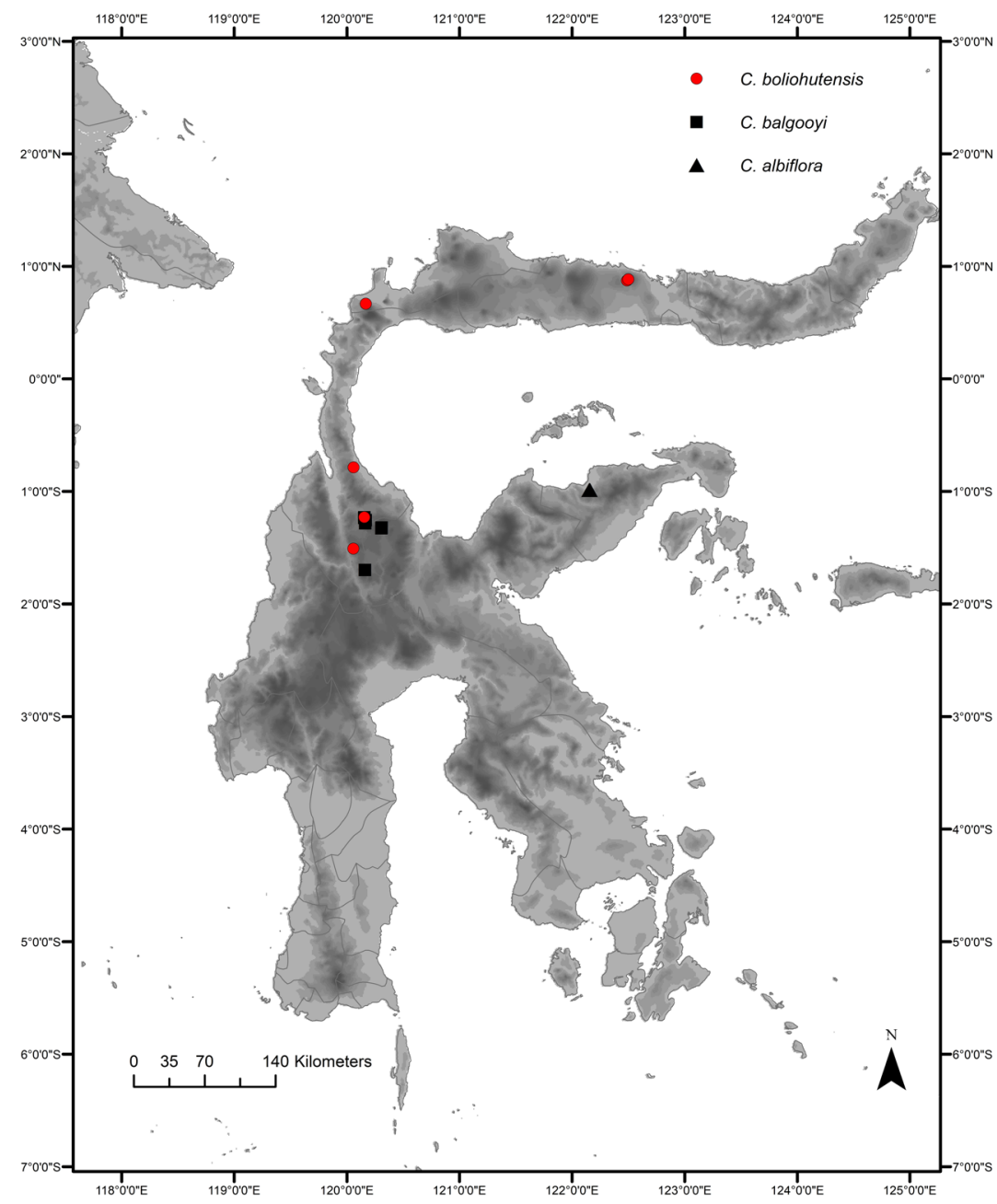

Figure 14. Distribution of Cyrtandra albiflora (black triangle), C. balgooyi (black squares) and C. boliohutensis (red circles).

distinguished from these by the distinctive tuft of hairs on the base of the anthers and the short peduncles, only 1-2 mm long in Cyrtandra boliohutensis and 5-20 mm long in the Bornean species.

4. Cyrtandra bruteliana Koord., Meded. Lands Plantentuin 19: 550, 627 (1898). - Type: Indonesia, Celebes [Sulawesi], Minahassa, Mt Lolombulan, 6 iv 1895, Koorders $17183 \beta$ (lectotype BO, designated here; isolectotype L). Figure 15.

Branching shrub to $2(-3) \mathrm{m}$ in height. Stems striate, sparsely hairy, more densely so on young growth. Leaves appearing alternate, occasionally opposite with one of each pair highly 

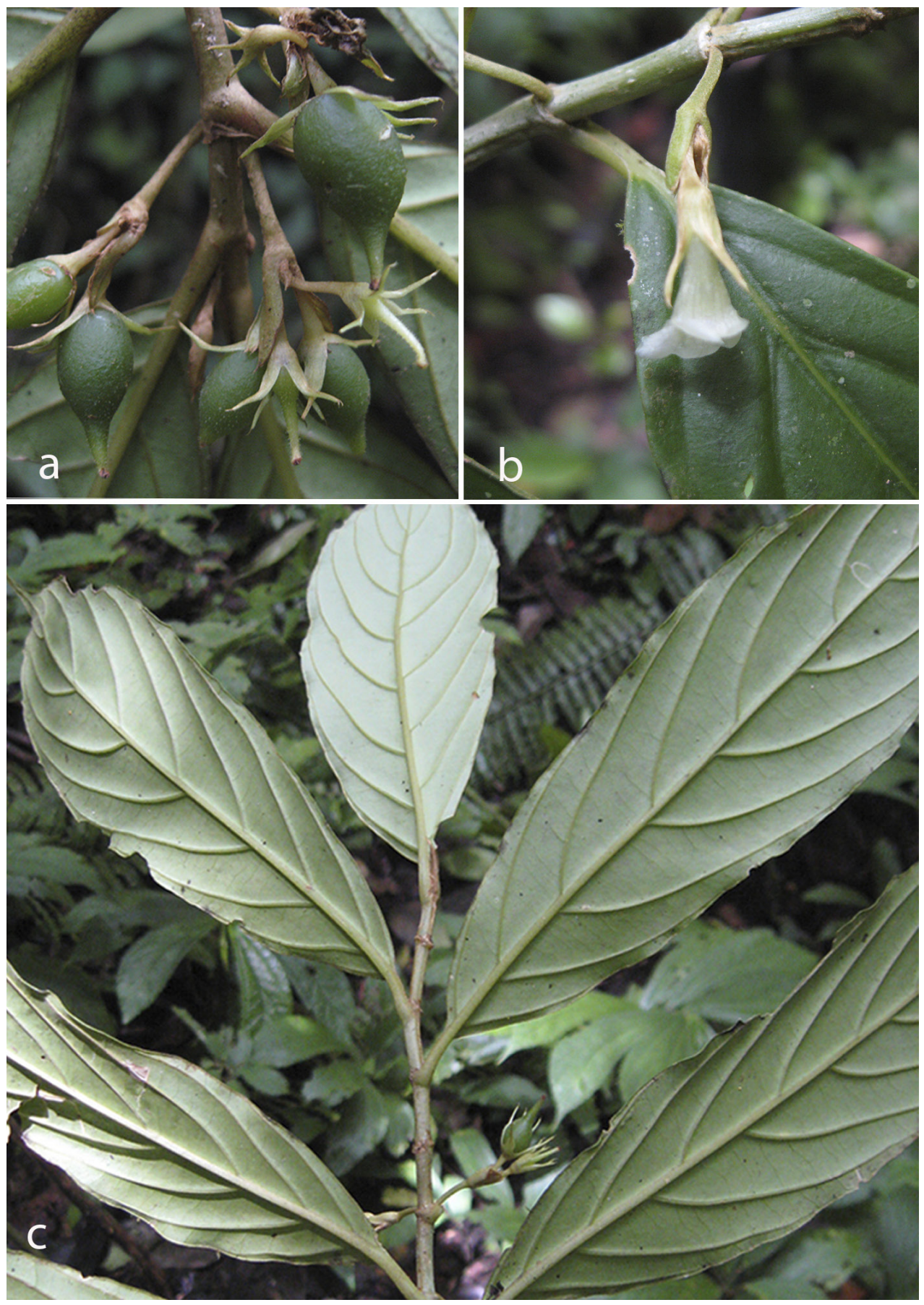

Figure 15. Cyrtandra bruteliana. a, Infructescence; $b$, side view of flower; $c$, stem and leaves. Photographs: Deden Girmansyah. Specimen: Girmansyah 1127. 
reduced; petiole 10-15 mm long, sparsely hairy to hairy; blades of larger leaf (6-)12-18 $\times(2-) 4-6.5 \mathrm{~cm}$, narrow elliptic to narrow oblong, acute and slightly asymmetrical at base, margins subentire to serrulate, apex long-acuminate to $15 \mathrm{~mm}$; $7-10$ pairs of lateral veins, veins prominent, curving upwards and running out to margin, tertiary venation faint, subglabrous above, sparsely hairy below, more densely so on midrib and veins. Inflorescences axillary, pedunculate in leaf axils or opposite leaves, 3-6(-8)-flowered; bracts green, lanceolate, not connate, $10-15 \times 5 \mathrm{~mm}$, sparsely hairy to hairy; bracteoles green, lanceolate, hairy, up to $7 \times 3 \mathrm{~mm}$; peduncles $5-15 \mathrm{~mm}$ long, densely hairy; pedicels 3-5 mm long, hairy. Calyx light green, evenly 5-lobed, 7-8 $\mathrm{mm}$ long, sparsely to densely hairy, lobes acuminate at apex, c. $5 \mathrm{~mm}$ long. Corolla white or yellow, sometimes with a greenish centre, more or less parallel-sided, widening only slightly to mouth, 12-13 mm long, lobes spreading, not strongly recurved, upper lobes c. $2 \times 3 \mathrm{~mm}$, lower lobes c. $3 \times 3 \mathrm{~mm}$, sparsely eglandular hairy externally. Stamens with filaments $3 \mathrm{~mm}$ long, attached $5 \mathrm{~mm}$ above base of corolla, glandular hairy; anthers less than $1 \mathrm{~mm}$ long, connected at tips before dehiscence; staminodes less than $1 \mathrm{~mm}$ long. Gynoecium $8 \mathrm{~mm}$ long; disc $1 \mathrm{~mm}$ long, cupular with undulate margin, glabrous; ovary subglabrous to sparsely glandular hairy; style glandular hairy for whole length; stigma capitate with two short, blunt lobes, c. $0.5 \mathrm{~mm}$ across. Fruits $5-10 \times$ 3-5 mm, broad-ovoid to subglobose, sparsely hairy, green, remnants of calyx persistent, style and stigmas also often persistent, bracts and bracteoles sometimes persistent.

Distribution. North Sulawesi, Central Sulawesi, Southeast Sulawesi (see Figure 17).

Habitat and ecology. Cyrtandra bruteliana has been collected in forest over a wide altitudinal range, from 500 to $1400 \mathrm{~m}$, but with most of the collections from altitudes over $1000 \mathrm{~m}$ in hill and upland forest.

Etymology. This species was named by Koorders after Dr Brutel de la Rivière, who assisted him with the publication of his comprehensive paper on fieldwork and botany in Minahasa (Koorders, 1898).

Proposed IUCN conservation category. Cyrtandra bruteliana has an EOO of $162,078 \mathrm{~km}^{2}$ and an AOO of $56 \mathrm{~km}^{2}$, based on a $2 \times 2 \mathrm{~km}$ grid cell size, under the B criteria (Bachman et al., 2011). Given the relatively high numbers of recent collections from both the north and southeast of the island, and the fact that at least some of the collections are from the protected areas of Mount Ambang and Mount Sojol Nature Reserves and Bogani Nani Wartabone (formerly Dumoga Bone) National Park (UNEP-WCMC \& IUCN, 2019), a provisional assessment of Least Concern (LC) is given for this species.

Additional specimens examined. INDONESIA. North Sulawesi. Bolaang Mongondow: Dumoga Bone National Park, vicinity of G. Sinombayuga, 30 ix 1991, Milliken 1132 (L); East Bolaang Mongondow: Mt Ambang Nature Reserve, 2 xi 2016, Barber, Atkins, Kartonegoro \& Kinho BAKK39 (BO, E); Minahasa: Mt Tangkoko, 28 vi 1954, Alston 16129 (A, BM, BO); Mt Manimporok, 8 ii 2009, Girmansyah 1127 (BO); 
Gurupahi, Urskogen, 14 iv 1917, Kaudern 59 (L, S); Minahasa, Koorders $17199 \beta$ (BO); South Minahasa: Leleasan, Wiau complex, 30 vi 1956, Forman 342 (BO, K, L).

Central Sulawesi. Donggala: Balukang, Siboang Desa, Dusun Maros, Camp 1, Puncak Pinimoang, east of Kampung Sipaton on the way to Mt Sojol, 20 vii 2002, Brown, Craven, Juswara \& Ramadhanil 82 (BO, CEB n.v., E, L); Parigi Moutong: Pangi Binangga, Uwe lutu, CA, 20 vii 2018, Ardi WI211 (KRB).

Southeast Sulawesi. Kolaka: Mount Watuwila, 24 iii 1929, Kjellberg 1020 (BO, S); Hutan Silui, Kecamatan Uluiwoi, 15 v 2008, Santika YS343 (BO, E, L); North Kolaka: Mt Mekongga, 19 iii, 2006, Girmansyah 584 (BO); Rante Angin subdistrict, Tinukari village, Mekongga mountain range, 7 viii 2009, Hidayat, Santika \& Hapid AH 4217 (BO, E).

Cyrtandra bruteliana is distinctive in Sulawesi due to its combination of apparently alternate leaves with faint tertiary venation and broad ovoid to subglobose fruits with persistent calyces. It is similar morphologically to Cyrtandra callicarpifolia Elmer from the Philippines (Elmer, 1910), particularly in the form of the inflorescence, although the leaves are smaller and narrower with serrate margins in the Philippine species.

Koorders did not specify a type for this species, so Koorders' own collection, Koorders $17183 \beta$, is designated here as the lectotype. The sheet from Bogor contains the most detailed collection information, so that sheet is selected.

5. Cyrtandra celebica Blume, Bijdr. Fl. Ned. Ind. 14: 772 (1826). - Rhynchocarpus coccineus Reinwardt ex de Vriese, PI. Ind. Bat. Orient. 11 (1856), nom. inval. - Cyrtandra coccinea var. celebica (Blume) C.B.Clarke in A.DC. \& C.DC., Monogr. Phan. 5: 256 (1883). - Type: Indonesia, Celebes [Sulawesi], in monte Lokkon, x 1821, Reinwardt mss no. 1541 (lectotype L, designated here).

Cyrtandra rhizantha Kraenzlin, J. Linn. Soc., Bot. 37: 277 (1906). - Type: Indonesia, Celebes

[Sulawesi], Forêt a l'entrée de la vallée du Tiram, 23-25 viii 1876, de la Savinierre 138 (holotype K). Figure 16.

Shrub or small tree to $10 \mathrm{~m}$ in height, usually much less. Stems subglabrous, woody, occasionally with prop roots. Leaves opposite or sometimes in threes; those of a pair or group well developed but somewhat unequal in size; petioles $2.5-6(-11) \mathrm{cm}$, glabrous, often warty at base; blades $8-40 \times 6-18.5 \mathrm{~cm}$, narrow ovate to narrow oblong, acute to obtuse and markedly oblique at base, margin subentire to crenate-serrate, acuminate at apex; 9-25 pairs of lateral veins, curving upwards and running out to margin, tertiary venation reticulate, sometimes quite obscure; sparsely hairy above, glabrous to sparsely hairy below, including midrib and veins. Inflorescences cauliflorous, often near base of stem, or occasionally in leaf axils, many-flowered; inflorescence axis pendulous or trailing often from a single point and then branching, appearing slightly notched from the remains of old bracts and bracteoles; bracts and bracteoles $10-15 \times 5-10 \mathrm{~mm}$, ovate, glabrous to sparsely hairy, connate sometimes only at base, sometimes to $3 / 4$ the length, soon caducous. Calyx tubular, slightly bilabiate, dark red or green, 12-20 mm long, lobes triangular, shortly acuminate at apex, three upper 


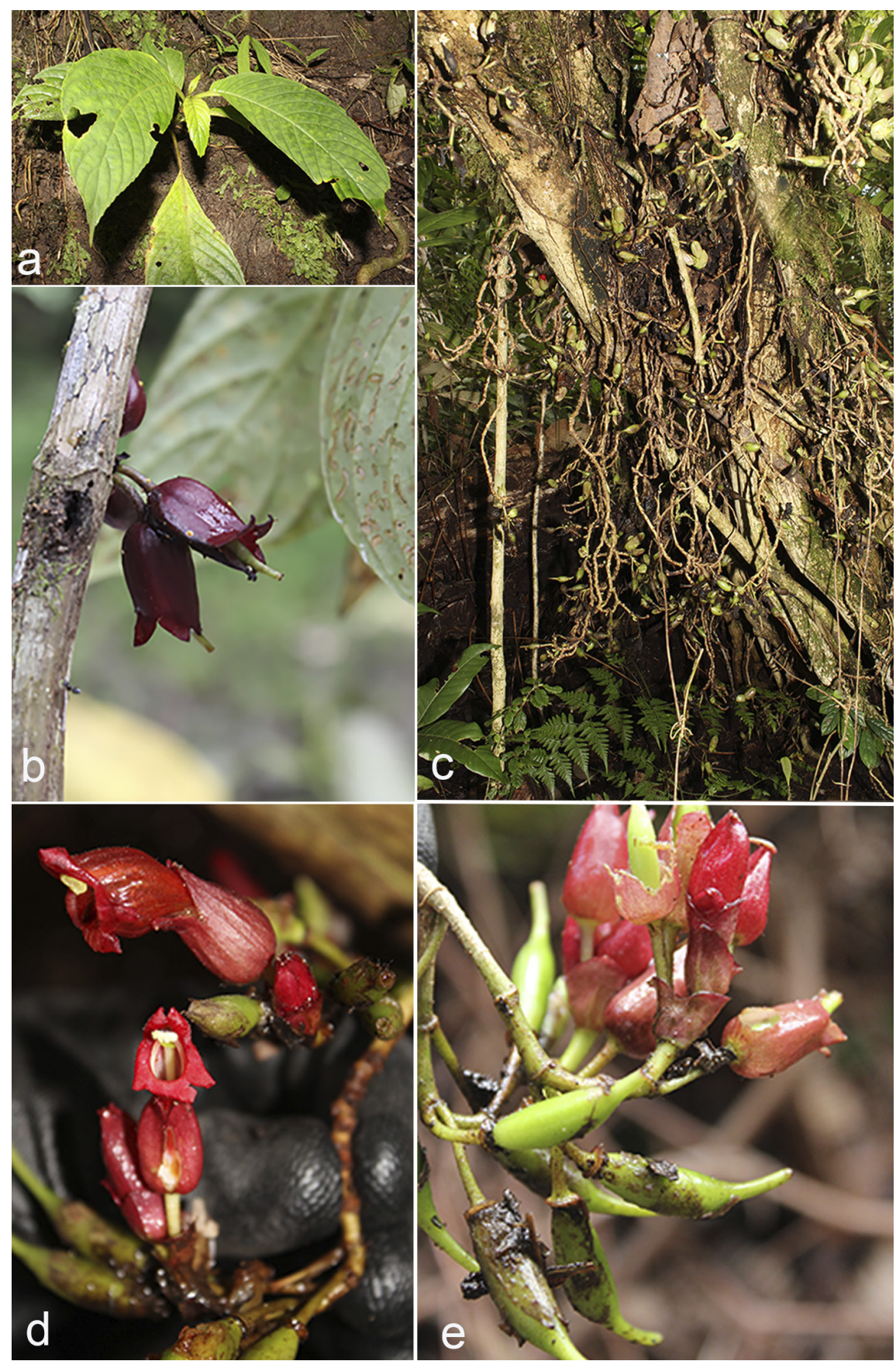

Figure 16. Cyrtandra celebica. a, Leaves; b, cauliflorous inflorescence; c, habit (small tree); d, front and side views of flowers; e, infructescence. Photographs: Sadie Barber. Specimens: Barber et al. BAKK8, BAKK12 and BAKK15. 
lobes very briefly divided, c. $3 \times 2 \mathrm{~mm}$, two lower lobes slightly longer, c. $5 \times 4 \mathrm{~mm}$, glabrous externally. Corolla red, 20-25(-35) mm long, tubular, very narrow towards base, mouth oblique with lower and lateral lobes recurved and folded under themselves thus appearing very small, c. $1 \times 4 \mathrm{~mm}$, upper lobes extending forwards, c. $2 \times 4 \mathrm{~mm}$, more or less glabrous externally with a scattering of short glandular hairs towards the lobes; lobes glandular hairy internally. Stamens with filaments 8-12 mm long, attached 11-18 mm from base of corolla, cream or pinkish, glabrous; anthers brown or cream, 2-3 mm long, connected at tips before dehiscence; staminodes 1-1.5 mm long. Gynoecium 20-30 mm long; disc cupular, slightly wider at base, sometimes with one side slightly lower than the other and slightly undulate margin, glabrous, $2 \mathrm{~mm}$ long; ovary glabrous; style glandular at the top of the style near the stigma, glabrous towards the ovary; stigma peltate, slightly bilobed, c. $2.5 \mathrm{~mm}$ across, green, exserted beyond the mouth of the corolla at maturity. Fruits narrow ovoid to oblong, $10-15 \times 3-5 \mathrm{~mm}$, glabrous, green when unripe, calyx not persistent, base of style persistent.

Distribution. North, Central, West and Southeast Sulawesi (Figure 17).

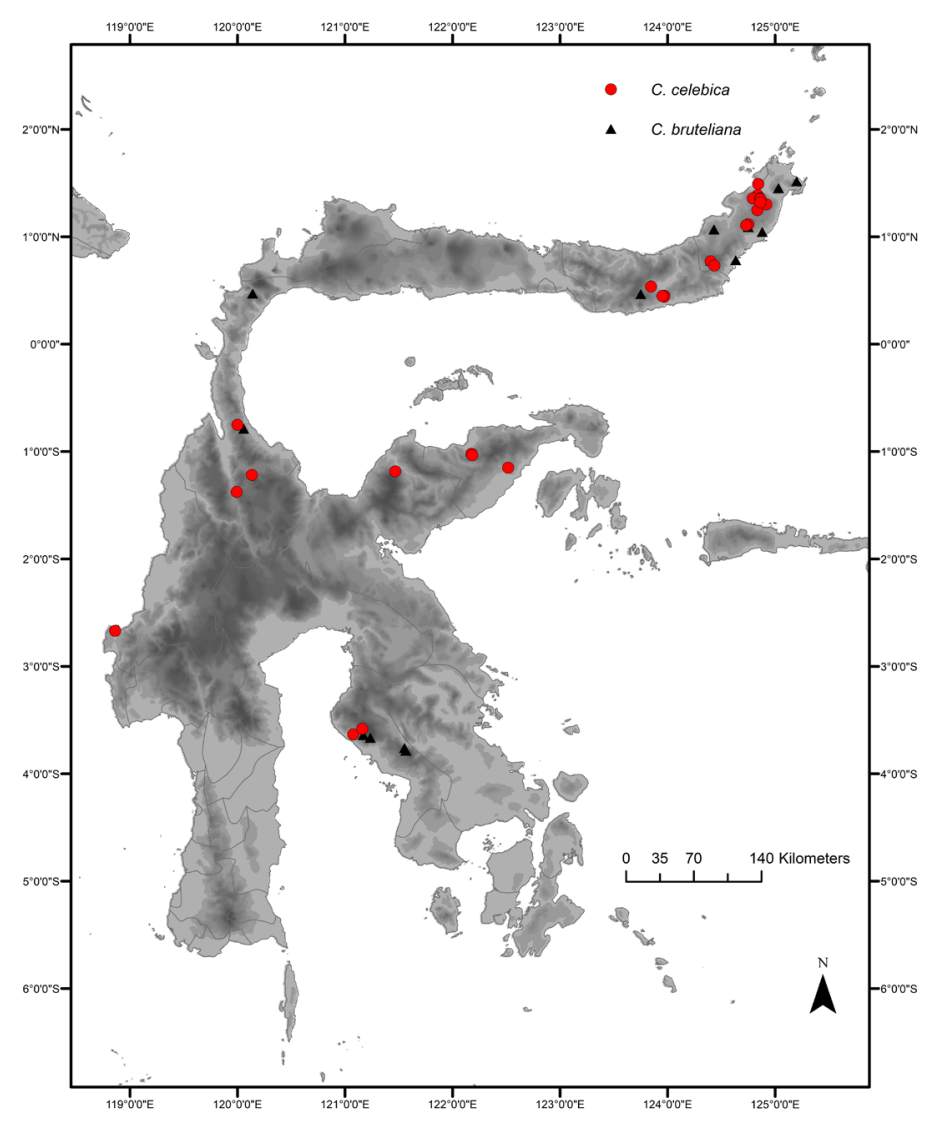

Figure 17. Distribution of Cyrtandra bruteliana (black triangles) and C. celebica (red circles). 
Habitat and ecology. Lowland to montane forest, often on vertical banks at an altitude of 50-1600 m.

Etymology. This species is named after the island of Sulawesi, using its former name Celebes (Blume, 1826).

Proposed IUCN conservation category. The EOO of this species is $210,408 \mathrm{~km}^{2}$ and the AOO is $116 \mathrm{~km}^{2}$, based on a $2 \times 2 \mathrm{~km}$ grid cell size, under the B criteria (Bachman et al., 2011). Cyrtandra celebica is one of the most widespread species on the island, with a very wide altitudinal range, from 50 to $1600 \mathrm{~m}$, and has been collected on a number of recent expeditions (in 2003, 2008, 2009, 2011 and 2016). For these reasons, it is given a category of Least Concern (LC).

Additional specimens examined. INDONESIA. North Sulawesi. Bolaang Mongondow: Tapakolintang area, 29 x 2016, Barber, Atkins, Kartonegoro \& Kinho BAKK12 (BO, E); Kasingolan River, 30 × 2016, Barber, Atkins, Kartonegoro \& Kinho BAKK15 (BO, E); Dumoga Bone National Park, Mt Mogogonipa, 12 iv 1985, de Vogel \& Vermeulen 7114 (K, L); East Bolaang Mongondow: Mt Ambang Nature Reserve, 2 xi 2016, Barber, Atkins, Kartonegoro \& Kinho BAKK49 (BO, E); Mt Ambang Nature Reserve, Bolrang Solfatara area, 19 iv 1985, de Vogel \& Vermeulen 7300 (K, L); Manado: Malalayang waterfall, 31 i 2019, Ardi WI393 (KRB); Manado, 28 xii 1894, Koorders 17198ß (BO, L); ibid., ii 1923, Wisse 101(BO); Minahasa: Mt Masarang, 4 xii 2003, Ambriansyah AA2656 (BO); Tondano, 1923, Boesveld s.n. (BO); 1894-5, Hose 799 (BM, K); Tondano, 1923, Kruyff 18 (BO); Sangihe Islands: Tabukan Selatan, 27 ix 1998, Hicks 87 (K); between Ganding peak and Batungbakara peak, 12 iv 1999, Hicks 225 (E, K); South Minahasa: Above Kelelonde, Soputan Mountains, 16 v 1954, Alston 15859 (A, BM, BO); Winowangan, 4 km E of Menado, 3 vii 1954, Alston 16189 (A, BM, BO, L, S); Mt Soputan, 11 x 1973, de Vogel 2497 (A); Talaud Islands: Karakelang, slope of G. Datua, 2 v 1926, Lam 2744 (BO, L); Tomohon: Tomohon, 5 vi 1954, Alston 15665 (A, BM, BO); Mt Mahawu, 23 v 1956, Forman 225 (BO, L); ibid., Wagio Crater, 4 vii 1956, Forman 385 (BO,

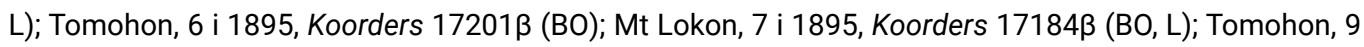
i 1895 Koorders $17179 \beta$ (BO, L).

Central Sulawesi. Banggai: inland from Batui, 15 x 1989, Coode 5944 (BO, K, L, SING); Bunta subdistrict, Sumber Agung, Mt Hek, Sungai Hek, 25 ii 2004, Hendrian, Newman, Scott, Saleh \& Supriadi 896 (E); Mt Hek, 14 iv 2008, Thomas \& Ardi 08-50 (BO, CEB n.v., E); Mt Katopas, 7 v 2008, Thomas \& Ardi 08-68 (BO, CEB n.v., E); Palu: Top of pass from Palu to east coast, 23 ii 2000, Mendum, Argent \& Hendrian 00129 (E); Sigi: Lore Lindu National Park, 29 vii 2018, Ardi WI248 (KRB); Area of Mt Nokilalaki, SE of Lake Lindu, 3 v 1975, Meijer 9981 (L).

West Sulawesi. Mamuju: Kona-kona River, Ds. Sondang, Kec. Kaluku Kab, 6 ii 1993, Afriastini 2053 $(\mathrm{BO}, \mathrm{K}, \mathrm{L})$.

Southeast Sulawesi. North Kolaka: Rante Angin subdistrict, Tinukari village, 2 viii 2009, Hidayat, Santika \& Hapid AH4095 (BO, E); ibid., 4 viii 2009, Potter, Sujadi, Shaputri, Asuar \& Sarpin 090804-01 (BO, E); ibid., 29 vi 2011, Widjaja, Sujadi, Santoso \& Hapid EAW9694 (BO, E).

Sulawesi: de Vriese 2 (L0277486 and L0277488) (L); de Vriese \& Teijsmann 2 (L0277487) (L); Unknown collector 202 (L0277489) (L).

Cyrtandra celebica is one of the most common and widespread species on Sulawesi. It is 
also one of the most striking, and although it is variable in terms of leaf shape and venation, it is easily recognised by its cauliflorous inflorescences and bright red corolla.

Blume (1826) originally described two species: Cyrtandra celebica from Sulawesi and C. coccinea Blume from Java. Clarke later reduced Cyrtandra celebica to a variety of $C$. coccinea and listed two de Vriese collections from Sulawesi as examplar specimens (Clarke, 1883). Although the morphological similarities between the Javan and Sulawesi taxa are striking, there are differences between them. The difference originally described by Blume is in the structure of the inflorescences, with those of the Javan species being subumbellate and those of Sulawesi being branched panicles (Blume, 1826). Clarke, when reducing the species to varietal level, also highlighted differences in the indumentum of the young growth, the Sulawesi specimens being more densely hairy when young (Clarke, 1883). In addition to these differences, the corollas of the Javan taxa, although usually red, can be quite pale and even yellowish white, and the corolla lobes are larger and not as strongly recurved as in the Sulawesi species.

Molecular phylogenetic research on the genus has confirmed that Cyrtandra coccinea from Java and Sulawesi are not conspecific, and in fact the Javan material is more closely related to $C$. floccosa and $C$. hispidula than to $C$. celebica (Atkins et al., 2020). Here, the Sulawesi material is treated as a distinct species, Cyrtandra celebica, as Blume originally proposed. Cyrtandra rhizantha was described in 1906 (Kraenzlin, 1906) from a collection from Minahasa in Sulawesi, and is treated as a synonym of $C$. celebica. The name Cyrtandra rhizantha was subsequently also used illegitimately by Schlechter for a completely unrelated white-flowered species from New Guinea (Schlechter, 1923).

Blume did not list any specimens when he described Cyrtandra celebica. The only specimen that was collected early enough to have been seen by him is Reinwardt 1541, which is designated here as the lectotype.

6. Cyrtandra engleri Koord., Meded. Lands Plantentuin 19: 628 (1898). - Type: Indonesia, Celebes [Sulawesi], Minahassa, Mt Lokon, 7 i 1895, Koorders $17204 \beta$ (lectotype BO, designated here).

Shrub or small tree to $4 \mathrm{~m}$ in height. Stems striate, hairy, densely so on young growth. Leaves opposite; one leaf of a pair markedly reduced or appearing alternate; petioles 6-10 mm long, densely hairy; blades of larger leaves $4.5-11 \times 1.5-3 \mathrm{~cm}$, oblanceolate to narrow oblong, acute at base, slightly asymmetrical, margins subentire to minutely serrulate, apex acuminate, acumen 2-5 mm long; 4 or 5 pairs of lateral veins, curving upwards and eventually running out to margin, tertiary venation reticulate, subglabrous above, sparsely hairy below, more densely so on midrib, veins and margin. Reduced leaves (where present) sessile, 2-3 mm long, cordate. Inflorescences axillary, sessile, 1- or 2-flowered; bracts 2-3 $\times 1 \mathrm{~mm}$, linear to narrow ovate, hairy; pedicels up to $5 \mathrm{~mm}$ long, densely hairy. Calyx evenly 5-lobed or occasionally appearing 4-lobed where two lobes are adpressed, whitish, flushed 
purple below, 10-13 $\mathrm{mm}$ long, lobes narrow, acuminate, 5-7 mm long, densely brown-hairy. Corolla white, sometimes with purple markings in throat, $15-20 \mathrm{~mm}$ long, narrow in basal half, widening gradually to mouth in apical half, upper lobes rounded $3 \times 2 \mathrm{~mm}$, lower and lateral lobes $4 \times 3 \mathrm{~mm}$, densely hairy externally. Stamens with filaments $3-4 \mathrm{~mm}$ long, attached 7-8 $\mathrm{mm}$ from base of corolla, filaments glabrous; anthers c. $1 \mathrm{~mm}$ long, connected at tips before dehiscence, some glandular hairs on back of anthers; staminodes $3,1 \mathrm{~mm}$ long, occasionally with a distinctive tuft of hairs at apex. Gynoecium 9-11 mm long; disc cupular with lobed, sparsely fringed margin, $1.5-2 \mathrm{~mm}$ long, glabrous; ovary and style densely eglandular hairy; stigma capitate, slightly bilobed, c. $1 \mathrm{~mm}$ across. Fruits oblong to narrow ovoid, 10-11 $\times 4 \mathrm{~mm}$, densely hairy, base of style persistent, calyx not persistent.

Distribution. North Sulawesi and Gorontalo (see Figure 20).

Habitat and ecology. Hill and upland forest at an altitude of 600-1400 m.

Etymology. This species is presumed to be named after H. G. A. Engler, a German botanist and contemporary of Koorders.

Proposed IUCN conservation category. This species occurs in North Sulawesi and Gorontalo and has an EOO of $6412 \mathrm{~km}^{2}$ and an $\mathrm{AOO}$ of $20 \mathrm{~km}^{2}$, based on a $2 \times 2 \mathrm{~km}$ grid cell size (Bachman et al., 2011). All the collections are from localities between 600 and $1400 \mathrm{~m}$, which includes some of the most threatened forest types on the island, due to population pressure and land conversion (Cannon et al., 2007), and only one collection locality falls within a protected area (Mount Lokon Nature Reserve) (UNEP-WCMC \& IUCN, 2019). The species has not been re-collected since 1956, despite this being one of the better-collected areas in Sulawesi. It is therefore probable that it occurs at five or fewer locations. Because of its restricted distribution, the known threat to its habitat type and the lack of protection, Cyrtandra engleri is considered to be Endangered (EN), B2ab(iii).

Additional specimens examined. INDONESIA. North Sulawesi. Bolaang Mongondow: viii 1917, Kaudern 186 (L, S); South Minahasa: Mt Mahawu, 21 vi 1956, Forman 185 (BO, K, L, SING); ibid., 23 vi 1956, Forman 224 (BO, K, L, SING); Tetepangan, Mt Lokon, 3 vii 1956, Forman 366 (BO, K, L).

Gorontalo. Gorontalo: Mt Boliohutu, 24 iv 2002, Atkins et al. 209 (BO, E, L).

Cyrtandra engleri is part of a group of six species on the island that share the characteristics of strongly anisophyllous leaves, where the smaller leaf is highly reduced; white or yellow corollas; and densely hairy calyces, corollas and fruits. The others in the group are Cyrtandra balgooyi, C. gambutensis, C. gorontaloensis, C. parvicalyx and C. widjajae.

Cyrtandra engleri is most similar to $C$. widjajae, a species originally described from Southeast Sulawesi (Kartonegoro \& Potter, 2014) but that also extends into North Sulawesi. It can be distinguished from Cyrtandra widjajae most easily by the smaller number of lateral vein pairs (4 or 5 in $C$. engleri versus 8-10 in $C$. widjajae) and the short-acuminate leaf apices (2-5 mm long in $C$. engleri versus up to $20 \mathrm{~mm}$ long in $C$. widjajae). Cyrtandra engleri 
also has a much denser, coarse indumentum and larger corollas (15-20 mm long versus 11-15 mm long), often with tufted staminodes and with dense eglandular hairs throughout the length of the style (as opposed to a transition to glandular hairs at the top of the style near the stigma in C. widjajae). Corollas are noted, in Cyrtandra engleri, as having purple markings in the throat, but the flowers of $C$. widjajae are completely white.

Two collections from Mount Boliohutu in Gorontalo Province, some distance from the localities of other collections in North Sulawesi, are included here, although the leaf shape is somewhat different and the corollas lack the purple markings. Further collections are required to clarify the status of these specimens.

Koorders $17204 \beta$ is selected here as the lectotype, because it was originally annotated with the name Cyrtandra engleri by Koorders.

7. Cyrtandra fasciata H.J.Atkins, Edinburgh J. Bot. 60(3): 309 (2004). - Type: Indonesia, Sulawesi, Gorontalo, Mt Gambuta, 10 iv 2002, Atkins et al. 54 (holotype BO; isotypes E, K, L). Figure 18.

Herb to $80 \mathrm{~cm}$ in height. Stems woody at base, bark tessellate, scaly, glabrous. Leaves opposite; both in each pair well developed but somewhat unequal in size; petioles $1-1.5 \mathrm{~cm}$ long, glabrous to sparsely hairy; blades $14-22 \times 3.5-4.5 \mathrm{~cm}$, narrow elliptic to narrow oblong, base decurrent, margin serrulate, short acuminate at apex; 9-12 pairs of lateral veins and some short side veins running to adjacent teeth, subglabrous above and below with some hairs on midrib and veins below. Inflorescences axillary, sessile, 1- to 3-flowered; bracts brown or light green, c. $20 \times 2 \mathrm{~mm}$, linear, apex acuminate, sparsely felted-hairy, not connate; pedicels 4-5 mm long, sparsely hairy. Calyx tubular, longitudinally ridged, flushed reddish pink at base, yellow above or pale yellow throughout, $28 \mathrm{~mm}$ long, three upper lobes c.7 mm, acuminate, two lower lobes united in a shallowly notched limb c.14 $\mathrm{mm}$ long, sparsely hairy. Corolla yellow with red stripes on lobes or pale yellow throughout, 32-40 mm long, erect, arcuate, narrow below, widening towards mouth, lobes strongly recurved, constricted just below rounded apex, all lobes $10 \times 5-6 \mathrm{~mm}$, sparsely hairy externally, densely glandular hairy internally, on lobes. Stamens with filaments c. $10 \mathrm{~mm}$ long, attached c. $18 \mathrm{~mm}$ above base of corolla, yellow; anthers c. $4 \mathrm{~mm}$ long, not cohering at tips before anthesis on specimens seen, back of anthers glandular hairy; staminodes c. $3 \mathrm{~mm}$ long. Gynoecium 20-25 mm long; disc cupular, margin even, glabrous, c. $1 \mathrm{~mm}$ long; ovary glabrous; style glandular hairy for whole length; stigma bilobed, lobes vertical, c. $1 \mathrm{~mm}$ long, densely glandular hairy on outer surface of lobes. Fruits ovoid, glabrous, green when unripe, $20 \times 10 \mathrm{~mm}$, calyx and base of style persistent.

Distribution. Gorontalo and Central Sulawesi (see Figure 20).

Habitat and ecology. Upland and montane forest at an altitude of 1000-1800 m.

Etymology. This species is named for its distinctive striped corolla (Atkins, 2004). 


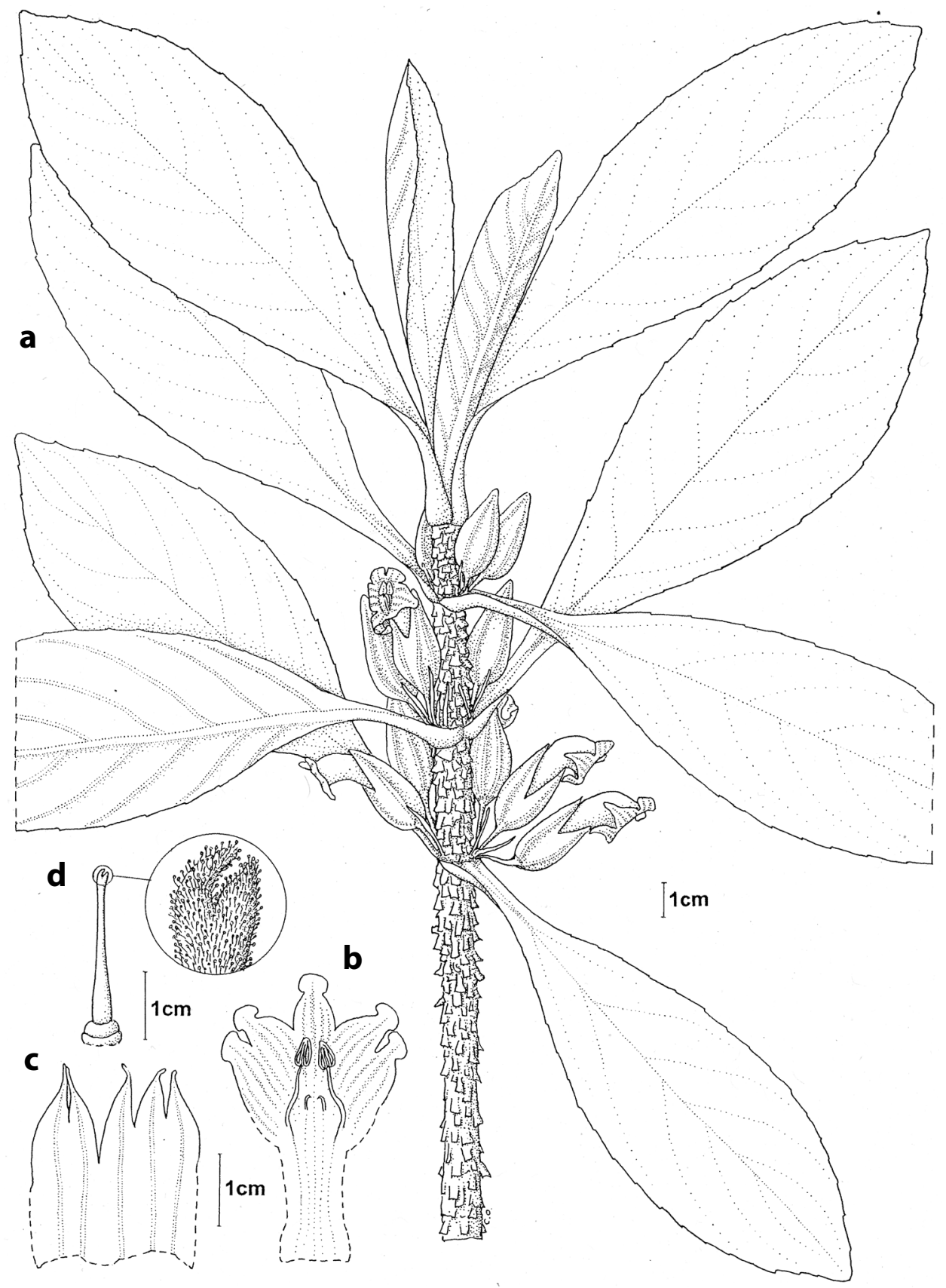

Figure 18. Cyrtandra fasciata. a, Habit; b, opened corolla, showing position of stamens and staminodes; c, opened calyx, showing inner surface; d, gynoecium, including detail of stigma. Drawn by Christina Oliver from Atkins et al. 54. Reproduced from Atkins (2004) with the permission of the Trustees of the Royal Botanic Garden Edinburgh. 
Proposed IUCN conservation category. Based on the collections of fertile material of Cyrtandra fasciata that can be identified with confidence, the EOO of this species is $8792 \mathrm{~km}^{2}$ and the $A O O$ is $12 \mathrm{~km}^{2}$, based on a $2 \times 2 \mathrm{~km}$ grid cell size, under the B criteria (Bachman et al., 2011). The type collection is from Mount Gambuta in the Bogani Nani Wartabone National Park, and the others are from the Mount Sojol and Mount Dako Nature Reserves (UNEP-WCMC \& IUCN, 2019). They are from relatively high altitudes in upland and montane forest, which are the least threatened forest types in Sulawesi (Cannon et al., 2007). Because of the relative lack of threat and the protected areas in which the species grows, a category of Least Concern (LC) is given for this species.

Additional specimens examined. INDONESIA. Central Sulawesi. Donggala: Mt Sojol, 26 ii 2000, Mendum, Argent \& Hendrian 00160 (BO, E); ibid., 27 ii 2000, Mendum, Argent \& Hendrian 00198 (BO, CEB, E, L); Sigi: Danau Kalimpa'a (Danau Tambing), 21 iii 2001, Kessler PK3060 (K, L); Tolitoli: Mt Galang-Dako, 13 vii 2018, Santoso \& Rusdi WS324 (BO).

cf. Cyrtandra fasciata

Central Sulawesi. Sigi: Lore Lindu National Park, Danau Tambing, 1700 m, 23 v 1979, van Balgooy 3442 (BO, E, L).

West Sulawesi. Polewali Mandar: Mamasa-Tabang Road, 21 vi 1974, Yoshida 1234 (BO).

Southeast Sulawesi. North Kolaka: Mt Mekongga, Tinukari, on the way to camp 3, 30 vi 2011, Widjaja et al. 9711 (BO, E).

Cyrtandra fasciata is similar vegetatively to C. flavomaculata H.J.Atkins \& Karton., C. kinhoi and $C$. longistamina in having decurrent leaves and tessellate stems. It can be distinguished from these, however, by its erect flowers with striped corolla lobes constricted below the tips. It also has smaller leaves and much narrower inflorescence bracts than those of Cyrtandra kinhoi, and shorter pedicels and much more tubular, ridged calyces than those of C. longistamina.

Two collections from West and Southeast Sulawesi (Yoshida 1234 and Widjaja et al. 9711) and one from Lore Lindu National Park in Central Sulawesi (van Balgooy 3442) have been placed here because they look most similar vegetatively to Cyrtandra fasciata. However, there is insufficient material to allow them to be identified with certainty.

8. Cyrtandra flavomaculata H.J.Atkins \& Karton., sp. nov.

Similar to Cyrtandra kinhoi Karton. \& H.J.Atkins in its tessellate stems and decurrent leaves but differing in its corolla colour and indumentum (corolla white with distinctive yellow markings on lobes and glabrous externally in $C$. flavomaculata versus corolla white or flushed pink without markings and glandular hairy externally in $C$. kinhoi), and its style indumentum (style densely glandular hairy in $C$. flavomaculata versus style glabrous, slightly eglandular hairy towards apex in C. kinhoi). - Type: Indonesia, Sulawesi, Central Sulawesi, Lore Lindu National Park, Mt Nokilalaki, Track to shelter 2, 24 vii 18, Ardi WI229 (holotype KRB). Figure 19. 


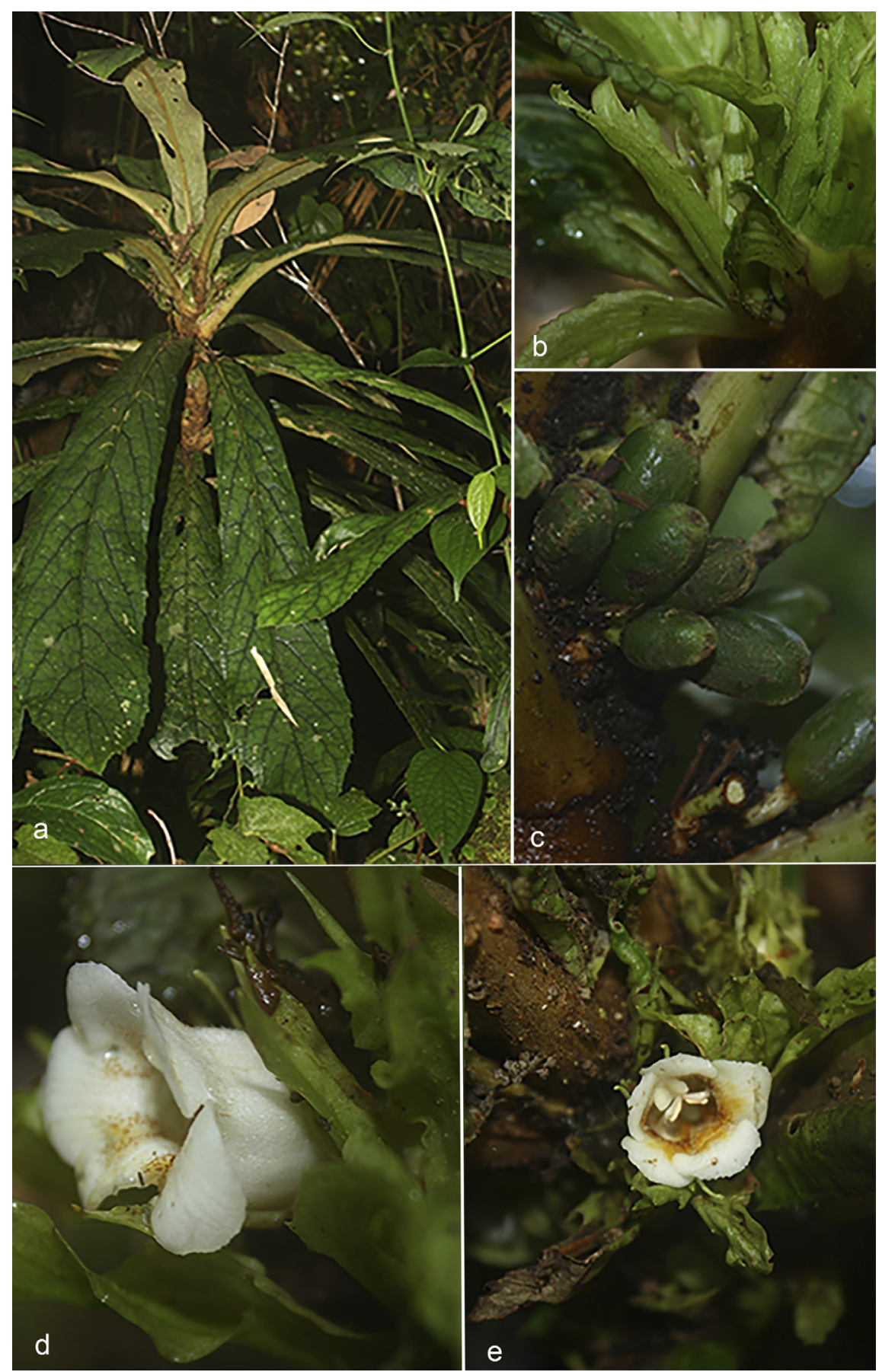

Figure 19. Cyrtandra flavomaculata H.J.Atkins \& Karton., sp. nov. a, Habit; b, bracts; c, fruits; d, side view of corolla; e, front view of corolla. Photographs: Wisnu Ardi. Specimen: Ardi WI299. 
Herb or soft wooded shrub to $2 \mathrm{~m}$ in height. Stems slightly tessellate and somewhat ridged. Leaves opposite, those of a pair subequal; petioles 1-2 cm long, sparsely hairy, winged and flushed white or pink; blades 21-25 ×5-6 cm, narrow oblong to narrow elliptic; base decurrent (appearing less so on older leaves as decurrent wing falls away), margin subentire towards the base, becoming serrate towards the apex, apex short acuminate; 11-18 pairs of lateral veins, looping up and running out to margin, tertiary venation reticulate, somewhat obscure; sparsely hairy above, more or less glabrous below with some hairs on the midrib and veins (more dense on young growth). Inflorescences axillary, subsessile, 4- to many-flowered, flowers at various stages of development; peduncle c. $5 \mathrm{~mm}$ long, glabrous; bracts narrow obovate, with a slightly serrate margin towards the apex, off-white to light green, 25-40 × 7-9 mm, glabrous, quite leathery; apex long-acuminate; pedicels c. $5 \mathrm{~mm}$ long, glabrous. Calyx tubular, $23 \mathrm{~mm}$ long, white, light green or reddish, somewhat warty on some specimens, more or less glabrous, appearing 4-lobed because two of the lobes are divided only very briefly at the apex, lobes triangular, long-acuminate, $15 \mathrm{~mm}$ long. Corolla white with distinctive yellow marks on lower, and occasionally also upper lobes, $42 \mathrm{~mm}$ long, funnel-shaped, narrow in basal half, then widening abruptly to mouth, more or less glabrous externally, lobes rounded, upper lobes $5 \times 8 \mathrm{~mm}$; lower and lateral lobes 8-10 × 8-10 mm; glandular hairy internally on lobes and in the tube below the anthers. Stamens with filaments c. $9 \mathrm{~mm}$ long, attached c. $20 \mathrm{~mm}$ from base of corolla, glabrous except for a few glandular hairs near the anthers; anthers c. $3.5 \mathrm{~mm}$ long, with a few glandular hairs, cohering at tips but not face to face before dehiscence; staminodes 3 , laterals $4 \mathrm{~mm}$ long, central one highly reduced, less than $1 \mathrm{~mm}$ long. Gynoecium 30-35 mm long; disc cupular with a slightly undulate margin, glabrous, $3 \mathrm{~mm}$ long; ovary glabrous, style densely glandular hairy; stigma bilobed, lobes $2.5-3 \mathrm{~mm}$ long. Fruits oblong, glabrous, c. $20 \times 6 \mathrm{~mm}$, green, base of style and calyx not persistent.

Distribution. Central, South and Southeast Sulawesi (Figure 20).

Habitat and ecology. Hill, upland and montane forest, sometimes in disturbed areas at an altitude of $500-1750 \mathrm{~m}$. One specimen (Hennipman 5939) is recorded as having been collected from a limestone area.

Etymology. This species is named for its distinctive yellow markings on the lower, and occasionally also upper, corolla lobes.

Proposed IUCN conservation category. The EOO of this species is $17,578 \mathrm{~km}^{2}$ and the AOO is $28 \mathrm{~km}^{2}$, based on a $2 \times 2 \mathrm{~km}$ grid cell size, under the B criteria (Bachman et al., 2011). Some of the collection localities fall within the protected area of the Lore Lindu National Park (UNEP-WCMC \& IUCN, 2019), but most are in areas without any formal protection. Cyrtandra flavomaculata has quite a wide altitudinal range, but many of the collections are from the more threatened hill forest zone (Cannon et al., 2007). Because of the low number 


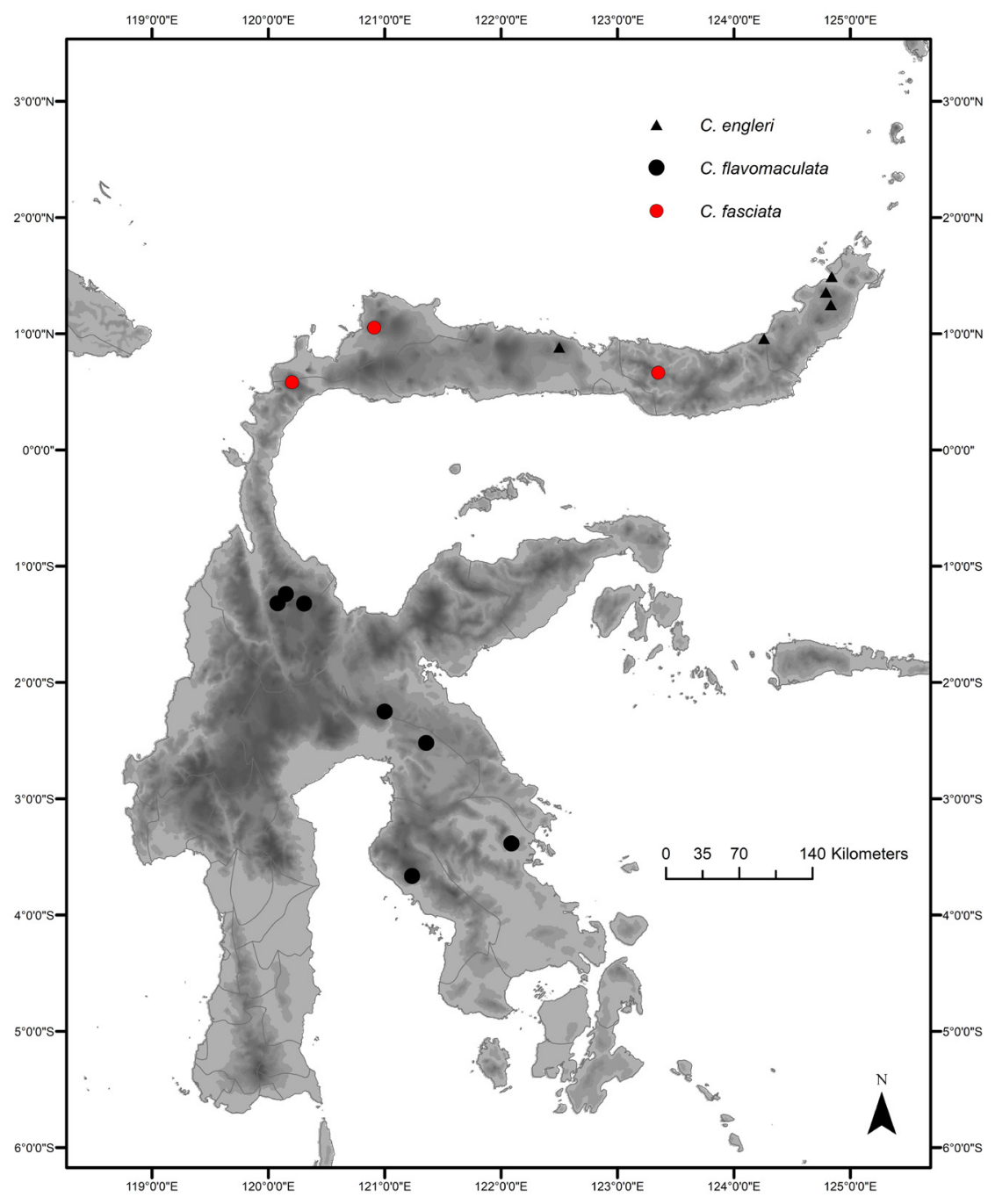

Figure 20. Distribution of Cyrtandra engleri (black triangles), C. fasciata (red circles) and C. flavomaculata (black circles).

of collections, relative lack of protection, and known threat to this habitat, it is considered to be Vulnerable (VU), B1ab(iii) + 2ab(iii).

Additional specimens examined. INDONESIA. Central Sulawesi. Sigi: Lore Lindu National Park, Tambing Lake vicinity, 4 viii 2018, Ardi WI299 (KRB); Road to Lake Lindu, c.60 km SSE of Palu, 30 v 1979, van Balgooy 3565 (A, BO, E, L); ibid., 30 v 1979, van Balgooy 3571 (A, BO, E, L).

South Sulawesi. East Luwu: Mt Pere, south of Soroako, 20 vi 1979, Hennipman 5939 (A, BO, E, L).

Southeast Sulawesi. North Kolaka: along the trail to Mt Mekkongga, 18 iii 2006, Girmansyah 580 (BO); North Konawe: Linomoyo Transmigration Village, 16 ii 2017, Ardi WI164 (KRB). 
Cyrtandra flavomaculata is most similar vegetatively to $C$. fasciata, $C$. kinhoi and $C$. longistamina in having decurrent leaves and tessellate stems. It can be distinguished from Cyrtandra fasciata most easily by its obovate inflorescence bracts 7-9 mm wide (as opposed to linear bracts that are c. $2 \mathrm{~mm}$ wide), and from C. longistamina by its oblong fruits on short pedicels up to $5 \mathrm{~mm}$ long (as opposed to subglobose fruits on long pedicels up to $30 \mathrm{~mm}$ long).

Some of the collections now included in this species were originally cited under Cyrtandra kinhoi (Kartonegoro et al., 2018). With better material of Cyrtandra flavomaculata, however, it is clear to see that there are differences in the corolla and style in terms of colouring and indumentum, as detailed in the diagnosis. Additionally, the base of the leaf has a distinctive white or purplish tinge and a papery texture that differs somewhat from the texture of the rest of the leaf; these characters are not seen in Cyrtandra kinhoi. The papery bases are sometimes lost as the leaves get older, so that they appear less decurrent.

The two species are also geographically separated, with Cyrtandra kinhoi restricted to North Sulawesi and C. flavomaculata distributed in Central, South and Southeast Sulawesi. According to notes on Hennipman 5939, the young leaves are used for the preparation of fish soup (sajor ikan).

9. Cyrtandra floccosa R.Bone \& H.J.Atkins, Edinburgh J. Bot. 70(3): 457 (2013). - Type: Indonesia, Sulawesi, South Sulawesi, Mt Rantemario, 26 iv 2009, Thomas \& Ardi 09-90 (holotype E; isotypes BO, L). Figure 21.

Shrub or tree 2-4 $\mathrm{m}$ in height. Stems strongly fenestrated, often with conspicuous swollen nodes, glabrescent, densely hairy when young. Leaves opposite, those of a pair more or less equal, often clustered at tips of branches; petioles 12-25 mm long, hairy; blades $6.5-13 \times$ 3-6 cm, elliptic to ovate, base acute or rounded, somewhat coriaceous, drying dark brown or black, margin crenate to serrate, apex acute; 7-9 pairs of lateral veins, looping upwards and running out to margin, tertiary venation reticulate; sparsely hairy above, hairy below densely so on midrib and veins. Inflorescences axillary, pedunculate, 1- or 2-flowered; peduncles c.6-11 mm long; bracts 3-5(-7) mm long, triangular to ligulate, leafy (with midrib); pedicels 7-20 mm long, densely hairy. Calyx tubular, green-brown, coriaceous, 19-34 mm long, two lower lobes 8-16 mm long, acuminate at apex, three upper lobes divided briefly at apex, densely hairy externally. Corolla light yellow, 26-45 mm long, tube narrow at base, widening and becoming slightly pouched at c. $1 / 3$ of length; lobes reflexed, two small dorsal lobes c. $5 \mathrm{~mm}$ long, two large lateral lobes c. $12 \mathrm{~mm}$ long, one ventral lobe c. $7 \mathrm{~mm}$ long, hairy to glabrescent externally, becoming sparsely hairy distally at ends of lobes, glabrous internally at base becoming glandular hairy distally. Stamens with filaments $9-10 \mathrm{~mm}$ long, attached c. $20 \mathrm{~mm}$ from base of corolla tube; anthers $3-4 \mathrm{~mm}$ long, cohering at tips before and during dehiscence; staminodes 3 , lateral staminodes c. $3 \mathrm{~mm}$ long, central staminode highly reduced, less than $1 \mathrm{~mm}$ long. Gynoecium c. $29 \mathrm{~mm}$ long; disc cupular with shallowly 


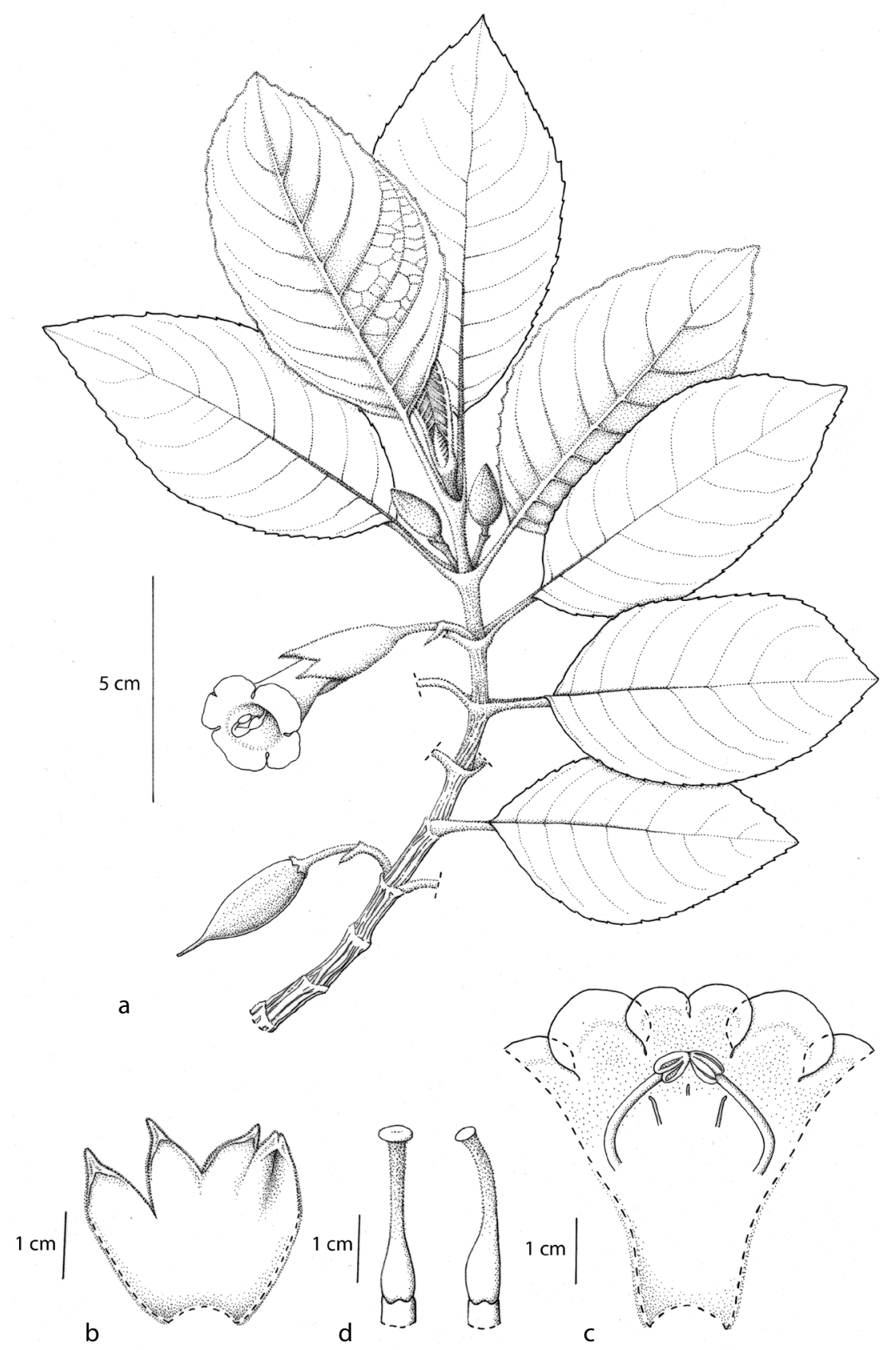

Figure 21. Cyrtandra floccosa. a, Habit; b, opened calyx, showing inner surface; c, opened corolla, showing position of stamens and staminodes; $d$, gynoecium and disc. Drawn by Claire Banks from Thomas \& Ardi 09-90. Reproduced from Bone \& Atkins (2013) with the permission of the Trustees of the Royal Botanic Garden Edinburgh. 
lobed margin, c. $4 \mathrm{~mm}$ long; ovary glabrous; style sparsely glandular hairy at base, becoming dense towards the apex; stigma peltate, c. $3 \mathrm{~mm}$ wide, surface densely papillose; stigma and stamens visible beyond corolla mouth. Fruits ovoid, green, drying black, 15-25 $\times 6-8 \mathrm{~mm}$, glabrous; calyx usually not persistent in fruit, base of style persistent.

Distribution. South Sulawesi: Latimojong Range (see Figure 24).

Habitat and ecology. Tropalpine forest at an altitude of 2800-3000 m.

Etymology. The specific epithet refers to the floccose indumentum, which is particularly dense on juvenile leaves and shoots (Bone \& Atkins, 2013).

Proposed IUCN conservation category. The EOO and the AOO are both $12 \mathrm{~km}^{2}$, based on a $2 \times 2 \mathrm{~km}$ grid cell size, under the B criteria (Bachman et al., 2011). Cyrtandra floccosa occurs in tropalpine vegetation over $2800 \mathrm{~m}$ in altitude in and around the western boundary of the Pegunungan Latimojong Protection Forest. Because this habitat type is in good condition and not considered at risk (Cannon et al., 2007), it is considered unlikely that the species is in decline. It has been collected on three different botanical expeditions in the Latimojong Mountains, most recently in 2009. Following Bone \& Atkins (2013), this species is considered to be of Least Concern (LC).

Additional specimens examined. INDONESIA. South Sulawesi. Enrekang: Rante Mario, 3000 m, 1929, Kjellberg 4046 (BO, S); Latimojong Mts south of Ninimori, 2950 m, 23 x 1969, Sands 296 (BO, E, K); ibid., Sands 344 (E, K); Mt Rantemario, 2788 m, 26 iv 2009, Thomas \& Ardi 09-89 (BO, E, L).

Cyrtandra floccosa is very distinctive in Sulawesi. It is characterised by its rusty, floccose indumentum throughout and large, pale-yellow flowers.

10. Cyrtandra gambutensis Karton. \& H.J.Atkins, Edinburgh J. Bot. 75(2): 180 (2018). Type: Indonesia, Sulawesi, Gorontalo Province, Mt Gambuta, 8 iv 2002, Atkins, Mendum, Newman, Hendrian \& Sofyan 38 (holotype E, isotype BO). Figure 22.

Shrub $0.7-2.5 \mathrm{~m}$ in height. Stems striate, short hairy, appearing pubescent. Leaves opposite, unequal; one leaf of a pair markedly reduced; petioles $0.8-1.3 \mathrm{~cm}$ long, hairy; blades 6-9.5 $\times 1-2.5 \mathrm{~cm}$, oblanceolate to narrow oblanceolate, base acute, slightly asymmetrical, margins subentire, apex short-acuminate, acumen 4-5 mm long; 8-11 pairs of lateral veins running straight out to margin without looping upwards, tertiary venation faint on herbarium specimens, glabrous above, hairy below, most densely so on midrib, veins and margin. Reduced leaves cordate, c. $5 \times 4 \mathrm{~mm}$, resembling the larger leaves in other respects. Inflorescences axillary, sessile, 2- or 3-flowered; bracts oblong-lanceolate, $5 \times 1 \mathrm{~mm}$, hairy on both sides; bracteoles lanceolate, hairy, 3-4 $\times 0.5 \mathrm{~mm}$; pedicels $3-5 \mathrm{~mm}$ long, densely hairy. Calyx tubular, white, green in bud, c. $15 \mathrm{~mm}$ long, densely hairy externally, three upper lobes c. $7 \mathrm{~mm}$ long, acuminate, two lower lobes c. $8 \mathrm{~mm}$ long, triangular, acuminate at apex. Corolla white with purple markings on lobes, tube narrow in basal $1 / 3$, widening to mouth 

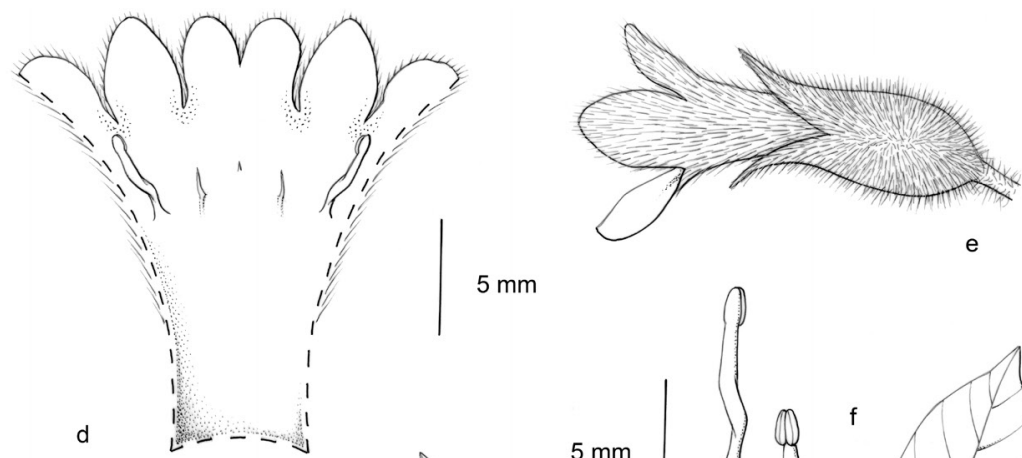

$5 \mathrm{~mm}$
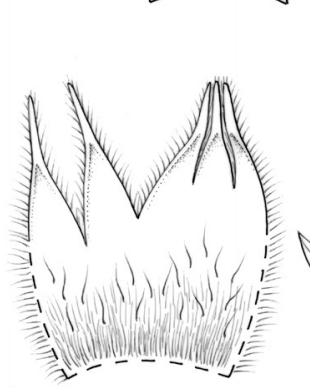

c
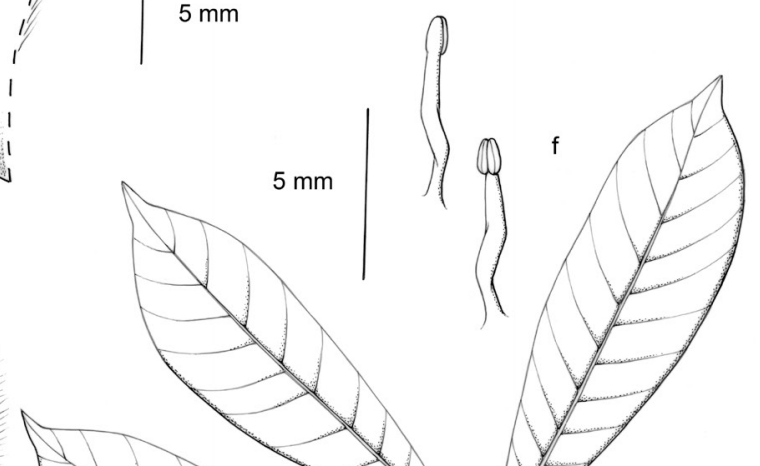

b
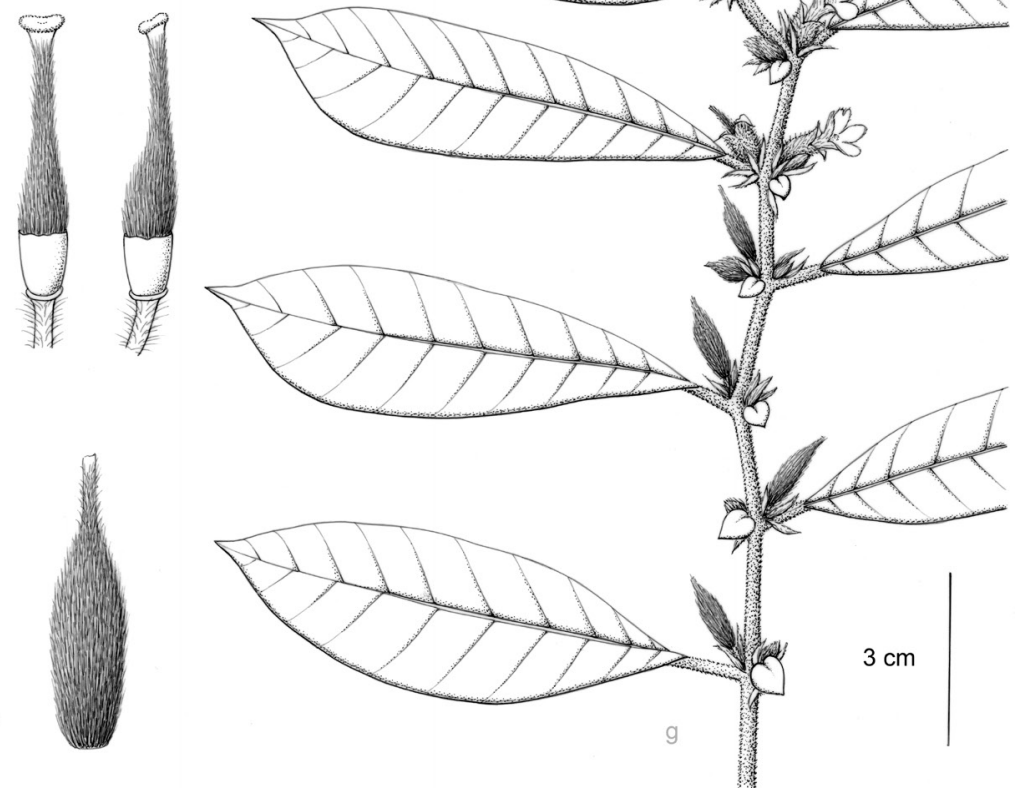

Figure 22. Cyrtandra gambutensis. a, Fruit; b, gynoecium, showing disc and pedicel; c, opened calyx, showing inner surface; $d$, opened corolla, showing position of stamens and staminodes; e, side view of corolla; f, stamens and anthers; g, habit. Drawn by Claire Banks from Atkins et al. 38. Reproduced from Kartonegoro et al. (2018) with the permission of the Trustees of the Royal Botanic Garden Edinburgh. 
in apical 2/3, 19-20 mm long, densely hairy externally, upper lobes rounded, c. $4 \times 2 \mathrm{~mm}$, lower and lateral lobes ovate, c. $5 \times 3 \mathrm{~mm}$. Stamens with filaments c. $5 \mathrm{~mm}$ long, attached c. $8 \mathrm{~mm}$ above base of corolla, white; anthers c. $1 \mathrm{~mm}$ long, not coherent at apices, purple; staminodes 3 , lateral staminodes c. $2 \mathrm{~mm}$ long, central staminode highly reduced, less than $1 \mathrm{~mm}$ long. Gynoecium c.11 mm long; disc cupular with undulate, fringed margin, glabrous externally, $2 \mathrm{~mm}$ long; ovary and style densely eglandular hairy; stigma bilobed, c. $2 \mathrm{~mm}$ across. Fruits oblong, dark green, cylindrical, densely hairy, c. $9 \times 3 \mathrm{~mm}$; calyx not persistent, base of style persistent.

Distribution. North Sulawesi and Gorontalo (see Figure 24).

Habitat and ecology. Hill and upland forest at an altitude of 520-950 m.

Etymology. Named after the mountain on which the type specimen was collected (Kartonegoro et al., 2018).

Proposed IUCN conservation category. The low number of collections means that it has not been possible to calculate an EOO for this species, but it has an AOO of $8 \mathrm{~km}^{2}$, based on a 2 $\times 2 \mathrm{~km}$ grid cell size, under the B criteria (Bachman et al., 2011). The collections are from hill and upland forest, which are threatened in Sulawesi (Cannon et al., 2007), but from within the boundaries of the Bogani Nani Wartabone National Park (UNEP-WCMC \& IUCN, 2019). We conclude that as long as the protection of the national park remains, the species should remain safe, and therefore Cyrtandra gambutensis is assessed as Least Concern (LC).

Additional specimen examined. INDONESIA. North Sulawesi. Bolaang Mongondow: Dumoga Bone National Park [Bogani Nani Wartabone], Mt Mogogonipa, 10 iv 1985, de Vogel \& Vermeulen 7081 (L).

This species is part of a group in Sulawesi that share the characteristics of strongly anisophyllous leaves (wherein the smaller leaf is highly reduced); white or yellow corollas; and densely hairy calyces, corollas and fruits. The other species in the group are Cyrtandra balgooyi, C. engleri, C. gorontaloensis, C. parvicalyx and C. widjajae. Cyrtandra gambutensis can be distinguished from these other species by its narrow leaves, sparse tertiary venation and secondary veins that run straight out to the margin without looping upwards.

11. Cyrtandra geocarpa Koord., Meded. Lands Plantentuin 19: 627 (1898). - Type: Indonesia, Celebes [Sulawesi], Minahassa, Mt Lolombulan, 15 iv 1895, Koorders 19377 (lectotype BO, designated here). Figure 23.

Branching herb or shrub to $1 \mathrm{~m}$ in height. Stems striate, glabrous, hairy on young growth. Leaves opposite; those of a pair well developed but somewhat unequal in size; petiole $10-15 \mathrm{~mm}$ long, sparsely hairy to hairy; blades $8-16(-24) \times 2-8(-10) \mathrm{cm}$, narrow oblong to oblanceolate, base acute, not decurrent, more or less symmetrical, apex acuminate; margin serrulate to lobed; 5-7 pairs of lateral veins, curving upwards and running out to margin, subglabrous above, sparsely hairy below, more densely so on midrib and veins. 


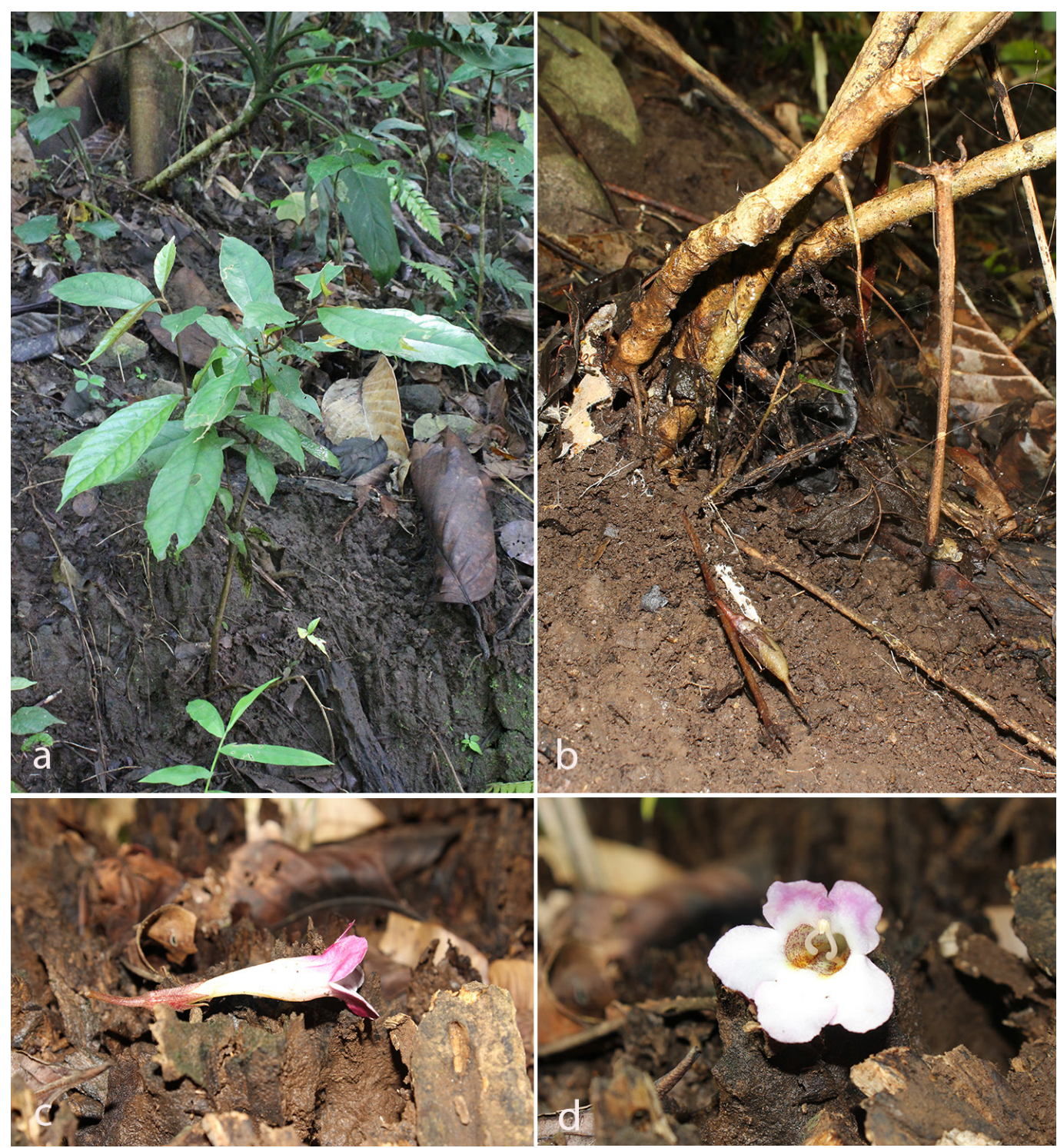

Figure 23. Cyrtandra geocarpa. a, Habit; $b$, fruit at base of plant; c, side view of flower; $d$, front view of flower. Photographs: Sadie Barber. Specimen: Barber et al. BAKK25.

Inflorescences trailing from base of main plant; trailing axis c. $1 \mathrm{~mm}$ in diameter, up to $50 \mathrm{~cm}$ long, glabrous; bracts 1-2 $\times 1 \mathrm{~mm}$, linear to linear-lanceolate, hairy, not connate. Calyx green to reddish brown, 9-12 mm long, 5-lobed, lobes subulate to linear, acuminate at apex, 3-8 mm long, hairy externally. Corolla white, sometimes with pale purple internally on lobes and yellow guidemarks in throat, $25-40 \mathrm{~mm}$ long, very narrow in basal half then widening to mouth, lobes spreading not strongly recurved, upper lobes c.7 $\times 6 \mathrm{~mm}$, lower and lateral 
lobes c. $9 \times 8 \mathrm{~mm}$, sparsely hairy externally, glandular hairs at base of lobes and on base of tube below filaments. Stamens with filaments 8-15 mm long, attached 12-20 mm from base of corolla, glabrous; anthers 1-2 mm long, cohering at apices and face to face before dehiscence; staminodes 3, 1.5-3 mm long. Gynoecium 15-20 mm long; disc cupular, $1.5-2 \mathrm{~mm}$ long, glabrous; ovary subglabrous; style sparsely eglandular and glandular hairy, more densely so towards apex; stigma appearing peltate or slightly bilobed, up to $2 \mathrm{~mm}$ across. Fruits oblong, brown-green, subglabrous, smooth when dry, $15 \times 5 \mathrm{~mm}$, calyx and style persistent.

Distribution. North Sulawesi, Gorontalo, Central Sulawesi (Figure 24).

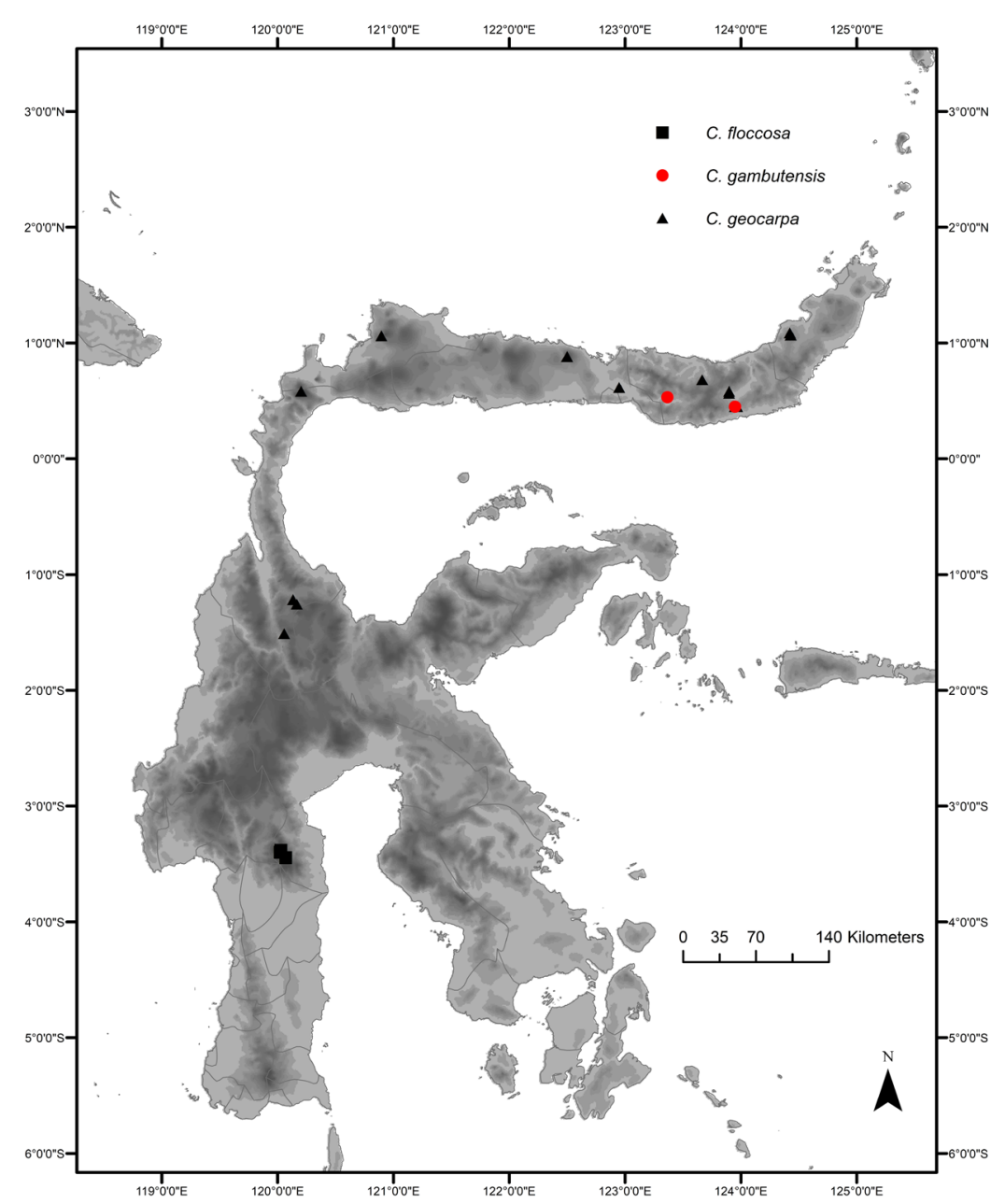

Figure 24. Distribution of Cyrtandra floccosa (black squares), C. gambutensis (red circles) and C. geocarpa (black triangles). 
Habitat and ecology. Lowland to upland forest at an altitude of 150-1500 m.

Etymology. The name of this species reflects the position of the flowers and fruits trailing from the base of the plant.

Proposed IUCN conservation category. The EOO of this species is $74,685 \mathrm{~km}^{2}$ and the AOO is $56 \mathrm{~km}^{2}$, based on a $2 \times 2 \mathrm{~km}$ grid cell size, under the B criteria (Bachman et al., 2011). It is found over a wide altitudinal range and from three of the island's provinces, and has been collected on a number of recent expeditions (in 2000, 2002, 2008 and 2016). Some of the collection localities fall within the boundaries of the Lore Lindu National Park, Mount Sojol Nature Reserve or Bogani Nani Wartabone National Park (UNEP-WCMC \& IUCN, 2019). Because of its wider distribution and higher level of protection in a number of areas, Cyrtandra geocarpa is considered to be of Least Concern (LC).

Additional specimens examined. INDONESIA. North Sulawesi. Bolaang Mongondow: Tapakolintang area, 29 xi 2016, Barber, Atkins, Kartonegoro \& Kinho BAKK7 (BO, E); Mt London, 30 xi 2016, Barber, Atkins, Kartonegoro \& Kinho BAKK25 (BO, E); Dumoga Bone National Park, 14 iii 1985, de Vogel \& Vermeulen 6527 (BO, L); ibid., 3 iv 1985, de Vogel \& Vermeulen 6971 (BO L); Minahasa: 220 km W of Menado, $50 \mathrm{~km}$ inland from Pangi, 7 iii 1990, Burley, Tukirin et al. 3701 (A, K, L); Minahassa, 1895, Koorders $17180 \beta$ (BO); South Minahasa: Mt Lolombulan, 4 ii 2019, Ardi WI406 (KRB).

Gorontalo. Bone Bolango: Lombongo, 30 iv 2002, Atkins et al. 252 (BO, E); Gorontalo: Path from Bululi to Mt Boliohutu, 22 iv 2002, Atkins et al. 139 (BO, CEB, E); ibid., 22 iv 2002, Scott 02-99, grown at RBGE as accession 20021222A, vouchered as Atkins 12 (E).

Central Sulawesi. Donggala: Mt Sojol, 5 ii 2000, Mendum et al. 00149 (BO, E); Sigi: Area of Mt Nokilalaki, 2 iv 1975, Meijer 9451 (BO, L); Area of Mt Nokilalaki, along Sungai Pehuia, 5 iv 1975, Meijer 9601 (BO, L); Area of Mt Nokilalaki, SE of Lake Lindu, 3 v 1975, Meijer 9971 (BO, L); Tolitoli: Mt Galang-Dako, 5 vii 2018, Santoso \& Rusdi WS186 (BO).

There are four Cyrtandra species in Sulawesi with trailing inflorescences that originate at the base of the stem: $C$. geocarpa, $C$. hypogaea, $C$. luteiflora and $C$. rantemarioensis. Cyrtandra geocarpa can be distinguished from the other geoflorous taxa by a combination of its slender (less than $1 \mathrm{~mm}$ in diameter), unbranched inflorescence axis, cupular disc and large white flowers.

One of the two specimens collected by Koorders and annotated with the name Cyrtandra geocarpa, Koorders $19377 \beta$, is designated here as the lectotype.

12. Cyrtandra gorontaloensis H.J.Atkins, Edinburgh J. Bot. 60(3): 307 (2004). - Type:

Indonesia, Sulawesi, Gorontalo, Mt Gambuta, 12 iv 2002, Atkins et al. 91 (holotype BO; isotypes E, L). Figure 25.

Branching shrub to $2 \mathrm{~m}$ in height. Stems striate, sparsely hairy, more densely so when young. Leaves appearing alternate, occasionally opposite with one of each pair vestigial and scale-like; petiole (5-)10-15 mm long, hairy; blade of developed leaf (4-)7-11.5 $\times 1.5-3.5 \mathrm{~cm}$, narrow oblong to oblanceolate, base acute and slightly asymmetrical, 


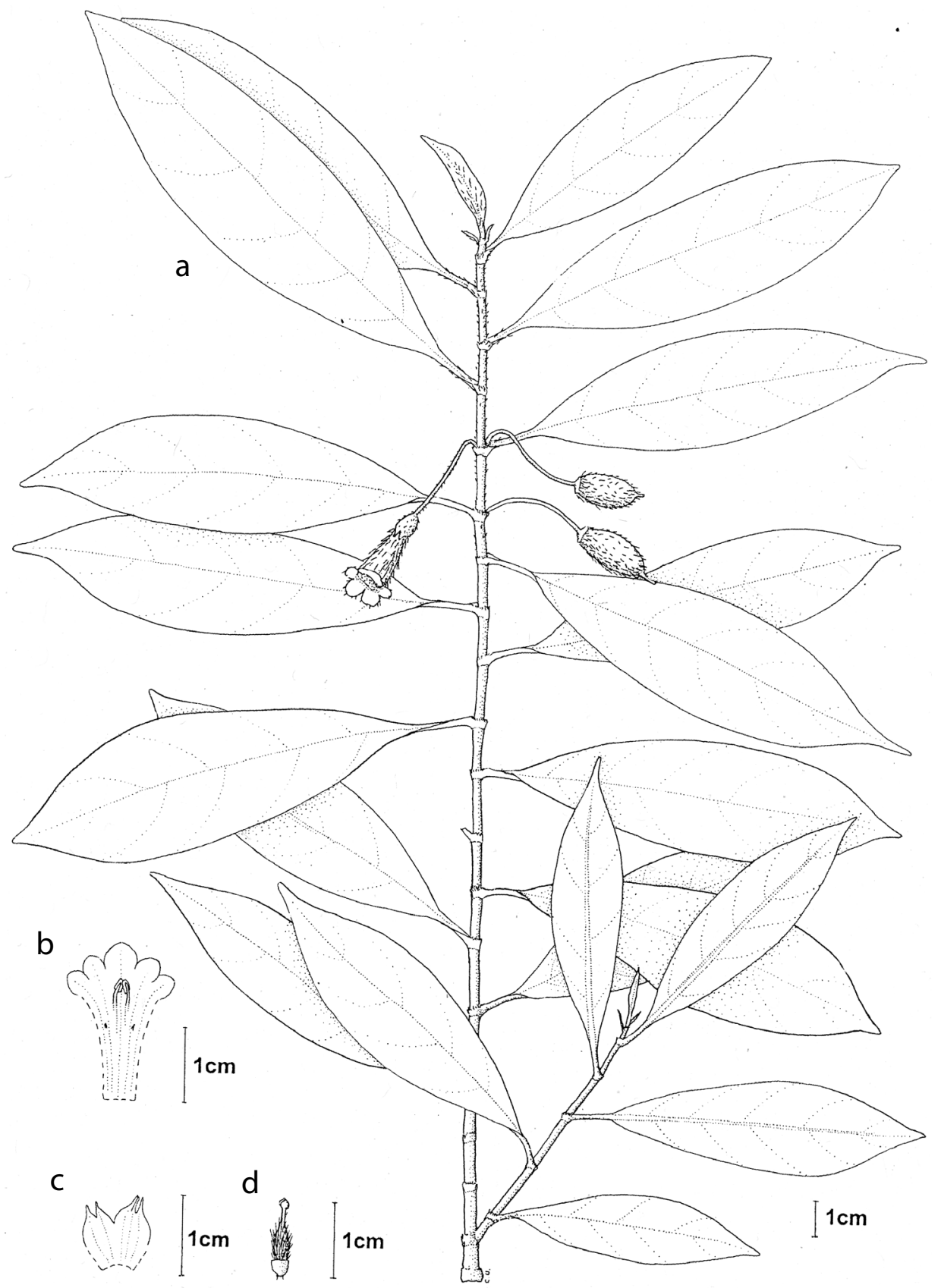

Figure 25. Cyrtandra gorontaloensis. a, Habit; b, opened corolla, showing position of stamens and staminodes; c, opened calyx, showing inner surface; d, gynoecium. Drawn by Christina Oliver from Atkins et al. 91 and Milliken 1131. Reproduced from Atkins (2004) with the permission of the Trustees of the Royal Botanic Garden Edinburgh. 
margin subentire, apex acuminate; 4 or 5 pairs of lateral veins curving towards margin, occasionally branching, tertiary venation sparse, subglabrous above and below, sparsely hairy on midrib and veins and along margin. Reduced leaves (where present) c. $5 \times 1 \mathrm{~mm}$, scale-like. Inflorescences axillary, 1- or 2-flowered, subsessile; peduncles up to $3 \mathrm{~mm}$ long, hairy; bracts 1-1.5 mm long, narrow ovate to linear; pedicels (5-)15-30 mm long, hairy. Calyx 7-10 mm long, pale green, three upper lobes united into a shallowly notched limb, two lower lobes similarly united, hairy externally. Corolla creamy white to pale yellow, 14-20 mm long, tube narrow below, gradually widening to mouth, lobes rounded, not recurved, upper lobes c. $4 \times 4 \mathrm{~mm}$, lower and lateral lobes slightly larger c. $5 \times 5 \mathrm{~mm}$, whitehairy externally. Stamens with filaments $3-4 \mathrm{~mm}$ long, attached c. $12 \mathrm{~mm}$ from base of corolla, glabrous, white; anthers c. $1.5 \mathrm{~mm}$ long, cohering at apices before dehiscence, brown; staminodes 3, $1 \mathrm{~mm}$ long. Gynoecium 8-16 mm long; disc unilateral, with a slightly lobed margin, 1-1.5 mm long, glabrous externally, hairy internally and with a fringe of hairs; ovary densely hairy; style densely hairy, glandular towards apex; stigma bilobed, c. $1 \mathrm{~mm}$ across. Fruits ovoid to oblong, green, $12-18 \times 5-6 \mathrm{~mm}$, hairy, calyx not persistent, base of style persistent.

Distribution. North Sulawesi and Gorontalo (see Figure 29).

Habitat and ecology. Upland forest at an altitude of 1300-1500 m.

Etymology. This species is named after the northern Sulawesi province of Gorontalo, from where the type specimen was collected (Atkins, 2004).

Proposed IUCN conservation category. The EOO of this species is $1613 \mathrm{~km}^{2}$ and the EOO is $16 \mathrm{~km}^{2}$, based on a $2 \times 2 \mathrm{~km}$ grid cell size, under the B criteria (Bachman et al., 2011). One of the collection localities falls within the boundaries of the Bogani Nani Wartabone National Park and one just outside, and two others are in the Mount Ambang Nature Reserve (UNEPWCMC \& IUCN, 2019), therefore their populations should be provided with some level of protection. All the collections are from upland forest between 1300 and $1500 \mathrm{~m}$, which in Sulawesi is a less threatened habitat than lowland areas (Cannon et al., 2007). Cyrtandra gorontaloensis is therefore considered to be of Least Concern (LC) due to the higher level of protection and low perceived threat (Cannon et al., 2007).

Additional specimens examined. INDONESIA. North Sulawesi. Bolaang Mongondow: Dumoga Bone National Park [Bogani Nani Wartabone National Park], vicinity of Mt Sinombayuga, 1400 m, 30 ix 1991, Milliken 1131 (L); East Bolaang Mongondow: Mt Ambang Nature Reserve, 1337 m, 2 xi 2016, Barber, Atkins, Kartonegoro \& Kinho BAKK43 (BO, E); Paya-paya area of Mt Ambang range, 4 xi 2016, Barber, Atkins, Kartonegoro \& Kinho BAKK68 (BO, E).

Cyrtandra gorontaloensis is part of a group in Sulawesi that share the characteristics of strongly anisophyllous leaves; white or yellow corollas; and densely hairy calyces, corollas and fruits. This species is distinctive within this group by its combination of seemingly 
alternate leaves (and reduced scale-like rather than cordate leaves, where present), sparse tertiary venation, unilateral disc, and style with glandular hairs towards the apex.

The species was first described from two collections from the Bogani Nani Wartabone National Park. Two recent collections from Mount Ambang (Barber et al. BAKK43 and BAKK68) with slightly shorter pedicels than the type and occasionally two flowers per inflorescence have allowed the original description, and its distribution, to be updated.

13. Cyrtandra hekensis Karton. \& H.J.Atkins, Edinburgh J. Bot. 75(2): 182 (2018). - Type:

Indonesia, Sulawesi, Central Sulawesi, Mt Hek, 9 iv 2008, Thomas \& Ardi 08-26 (holotype BO, isotype E). Figure 26.

Herb to $25 \mathrm{~cm}$ in height. Stems ridged, striate, upper stem appearing reddish, from dense, coarse indumentum on young growth, older stems glabrous. Leaves opposite, slightly unequal; those of a pair well developed but one slightly smaller; petioles $0.8-2 \mathrm{~cm}$ long, densely, coarse-hairy on young growth becoming glabrous on older growth; blades 7-7.5 $\times 1.6-3 \mathrm{~cm}$ (larger leaves), 3.5-5 × 1.3-1.7 cm (smaller leaves), narrow elliptic or oblong to somewhat oblanceolate, base decurrent, only narrowly winged at base, margin serrate, apex acuminate; 4-6 pairs of lateral veins and reticulate tertiary venation; dark green and mostly glabrous above with some hairs towards the base, paler green and with scattered hairs below with coarse hairs on the midrib and veins. Inflorescences axillary, subsessile to shortly pedunculate, 1- or 2-flowered; peduncles red, 2-3 mm long, hairy; bracts green, $9 \times 5-6 \mathrm{~mm}$, ovate, connate c. $4 \mathrm{~mm}$ from base, with some coarse hairs on midrib and margins, margin slightly serrate; bracteoles paired, green, 6-8 $\times 3 \mathrm{~mm}$, oblong, with coarse hairs on midrib and margins; pedicels 2-3 mm long, glabrous. Calyx tubular, pale green, 10-11 mm long, upper lobes c. $2 \mathrm{~mm}$ long, lower lobes c. $3 \mathrm{~mm}$ long, acuminate, glabrous except for a few tufts of hair at apex. Corolla white with greenish yellow markings in throat, c. $15 \mathrm{~mm}$ long, tube narrow in lower $1 / 3$, widening to mouth in apical $2 / 3$, hairy externally in the apical $1 / 3$, particularly densely so towards the mouth, upper lobes rounded, $3-4 \times$ $3 \mathrm{~mm}$, lower and lateral lobes rounded, c. $3 \times 3 \mathrm{~mm}$. Stamens with filaments c. $5 \mathrm{~mm}$ long, attached c. $6 \mathrm{~mm}$ from base of corolla, glabrous; anthers c. $1 \mathrm{~mm}$ long, coherent at apices; staminodes 2, c. $0.5 \mathrm{~mm}$ long. Gynoecium c. $10 \mathrm{~mm}$ long; disc cupular with lobed margin, glabrous externally, c. $1.5 \mathrm{~mm}$ long; ovary glabrous, style eglandular hairy towards apex; stigma slightly bilobed, lobes small, c. $1 \mathrm{~mm}$ across. Fruits ovoid, glabrous, verrucose, drying light brown, $6 \times 4 \mathrm{~mm}$; base of style and calyx persistent, bracts sometimes persistent.

Distribution. Central Sulawesi (see Figure 29).

Habitat and ecology. Hill forest at an altitude of 420-660 m.

Etymology. This species is named after the mountain on which it was collected (Kartonegoro et al., 2018). 


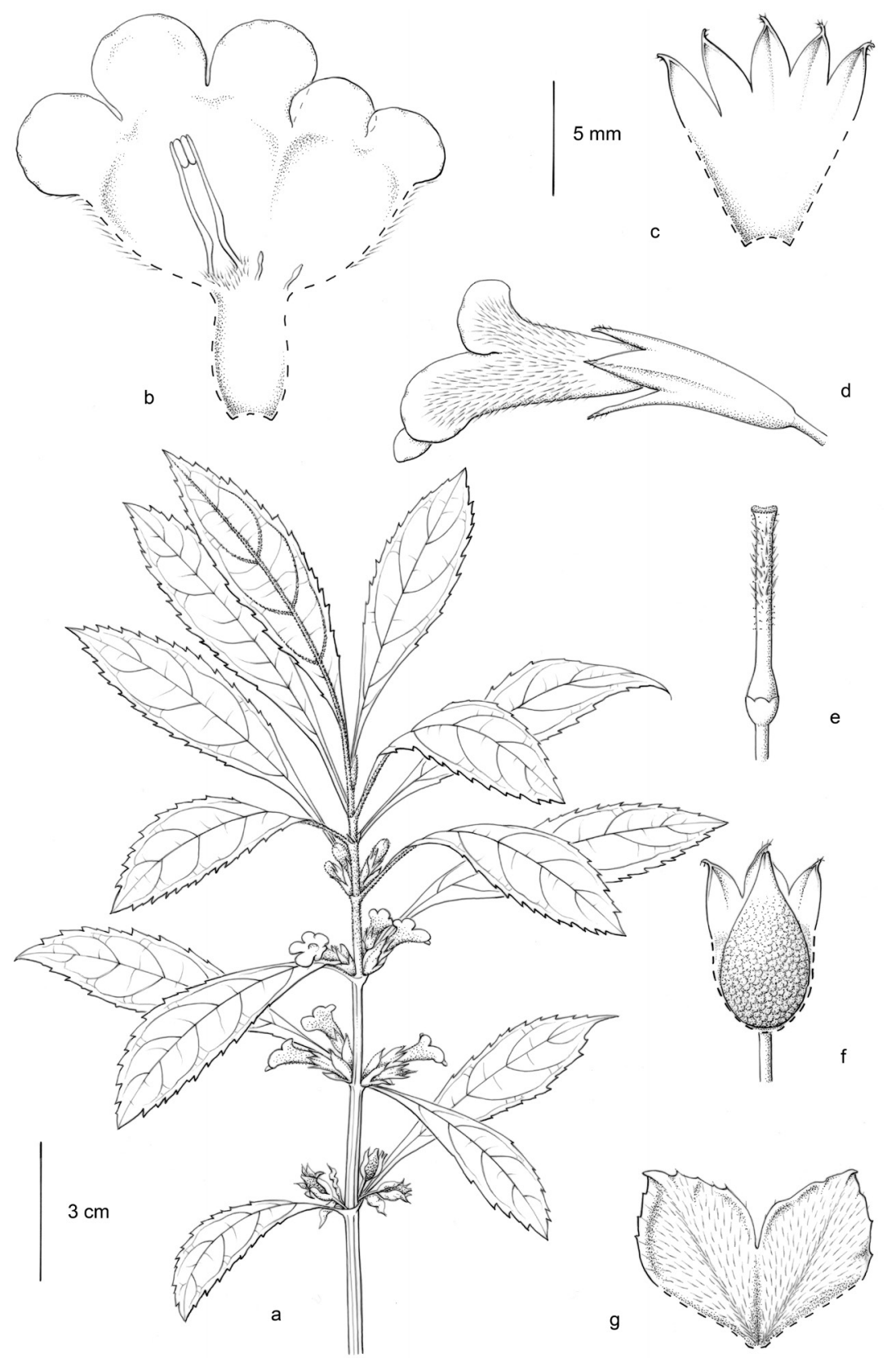

Figure 26. Cyrtandra hekensis. a, Habit; b, opened corolla, showing position of stamens and staminodes; c, opened calyx, showing inner surface; $d$, side view of corolla; e, gynoecium, showing disc and top of pedicel; $f$, fruit with persistent calyx partially removed; $g$, bracts. Drawn by Claire Banks from Hendrian et al. 901. Reproduced from Kartonegoro et al. (2018) with the permission of the Trustees of the Royal Botanic Garden Edinburgh. 
Proposed IUCN conservation category. The low number of collections for Cyrtandra hekensis means that it is not possible to calculate an EOO, but it has an AOO of $4 \mathrm{~km}^{2}$, based on a $2 \times 2 \mathrm{~km}$ grid cell size, under the B criteria (Bachman et al., 2011). The species is known only from Mount Hek, Banggai Regency, where it was collected at relatively low altitude during expeditions in 2004 and 2008. This forest type is one of the most threatened in Sulawesi (Cannon et al., 2007) and Mount Hek is in an area with no formal protection (UNEP-WCMC \& IUCN, 2019). It is, however, in one of the most under-collected areas of Sulawesi (Kessler et al., 2002; Cannon et al., 2007), and it is possible that there are more populations of this species. To reflect its narrow distribution in a single location in a threatened forest type and lack of formal protection (Cannon et al., 2007), Cyrtandra hekensis is assessed as Critically Endangered (CR), B2ab(iii). Habitat protection and ex situ conservation are recommended.

Additional specimen examined. INDONESIA. Central Sulawesi. Banggai: Mt Hek, 26 ii 2004, Hendrian, Newman, Scott, Saleh \& Supriadi 901 (E).

Cyrtandra hekensis is most similar to the widespread C. polyneura in its subequal, decurrent leaves, bracteate inflorescence, and white flowers with greenish yellow markings in the throat but can be distinguished by its much smaller, narrower leaves, fewer flowers per inflorescence, and coarser indumentum on young growth.

14. Cyrtandra hendrianii Karton. \& H.J.Atkins, Edinburgh J. Bot. 75(2): 185 (2018). - Type: Indonesia, Sulawesi, Central Sulawesi, Mt Hek, 660 m, 25 ii 2004, Hendrian, Newman, Scott, Nazre Saleh \& Supriadi 883 (holotype BO, isotype E). Figure 27.

Shrub to $2 \mathrm{~m}$ in height. Stems striate, reddish, more or less glabrous, slightly hairy in axils. Leaves opposite, subequal; petioles red, $2-4 \mathrm{~cm}$ long, densely hairy when young, becoming more glabrous with age; blades, $16.5-29.5 \times 5.5-9.5 \mathrm{~cm}$, narrow oblong, narrow elliptic or oblanceolate, base decurrent, only narrowly winged at base, margin serrate, apex acute to short acuminate; 8-11 pairs of lateral veins and with reticulate tertiary venation; dark green and mostly glabrous above with a few scattered hairs and on the tips of the marginal teeth, paler green below, with red to pink venation, densely fine hairy on midrib and veins with some scattered hairs on the blade. Inflorescences axillary, subsessile, with c.8-10 flowers at various stages of development; peduncle 1-2 mm long, sparsely hairy; bracts greenish, 25-35 × 5-6 mm, oblong to lanceolate, acuminate, with shallowly serrate margins and a few scattered hairs externally, more densely hairy along the margins and at the apex; bracteoles 15-20 mm long, lanceolate to linear, long-acuminate, sparsely hairy, more densely hairy along margins and particularly at the apex; pedicels 5-7 $\mathrm{mm}$ long sparsely hairy, extending slightly in fruit. Calyx tubular, red, 7-8.5(-10) mm long, appearing 2-lobed, lobes triangular, $3-3.5(-5) \mathrm{mm}$ long, acuminate, divided very briefly at the apex into three in the upper lobe and two in the lower, sparsely hairy at the base, more densely so at apex. Corolla pink, 


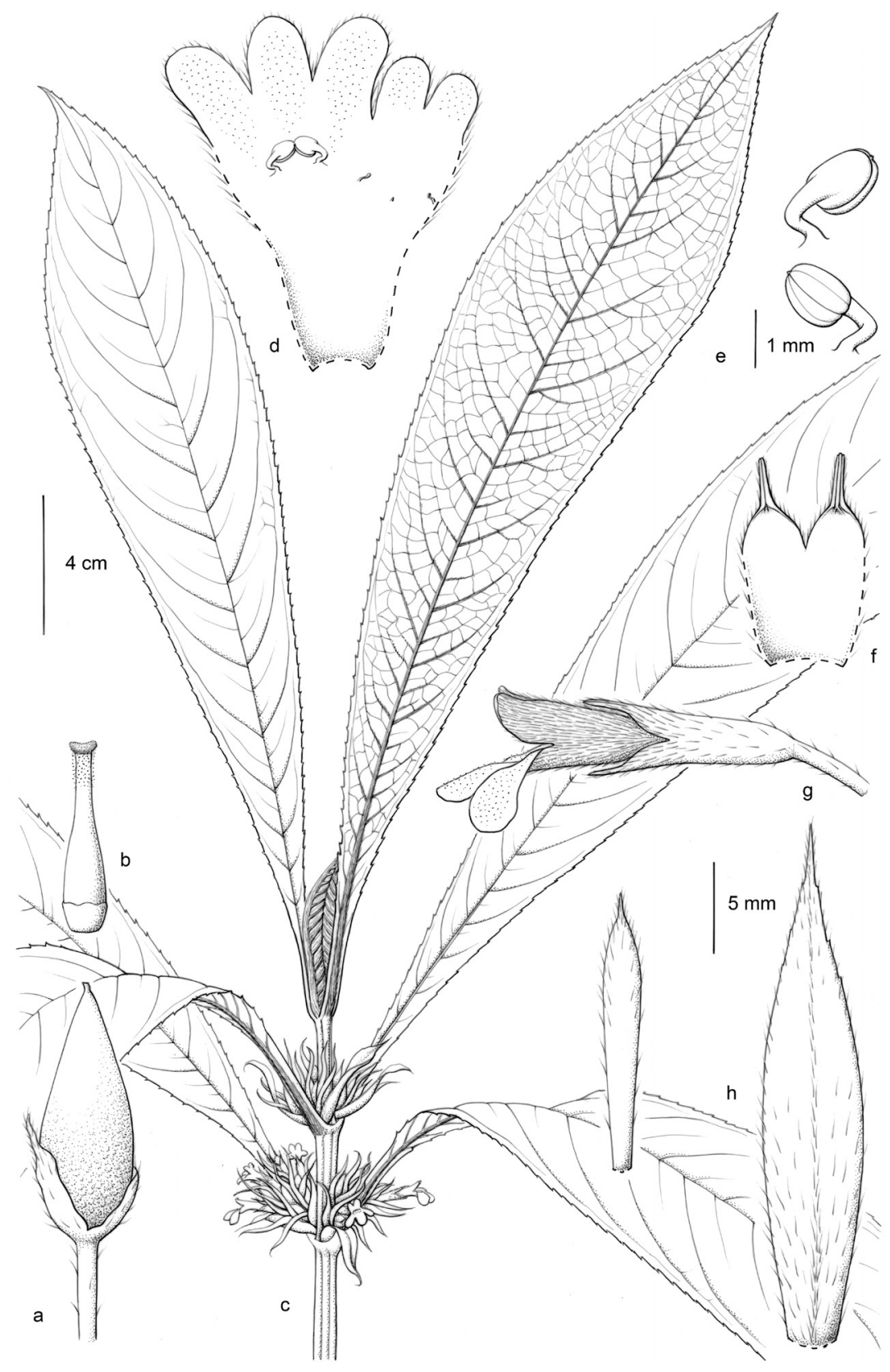

Figure 27. Cyrtandra hendrianii. a, Fruit; b, gynoecium including disc; c, habit; $d$, opened corolla, showing position of stamens and staminodes; e, anthers; $f$, opened calyx, showing inner surface; $g$, side view of corolla; h, bract and bracteole. Drawn by Claire Banks from Hendrian et al. 883. All other parts drawn from Scott 503 (accession 20040646A). Reproduced from Kartonegoro et al. (2018) with the permission of the Trustees of the Royal Botanic Garden Edinburgh. 
15-18 mm long, narrow funnelform, lobes rounded, lower lobes slightly more elongate, spreading to somewhat recurved, c. $4 \times 3 \mathrm{~mm}$, hairy externally with a dense covering of short glandular hairs internally on the lobes and in the mouth of the corolla. Stamens with filaments 1.5-2 mm long, attached c. $8 \mathrm{~mm}$ from base of corolla, glabrous; anthers c. $1 \mathrm{~mm}$ long, glabrous, cohering at apices; staminodes 3, c. $1 \mathrm{~mm}$ long, central one slightly shorter. Gynoecium c. $10 \mathrm{~mm}$ long; disc cupular, $2 \mathrm{~mm}$ long, glabrous with undulate margin; ovary glabrous; style with short, glandular hairs particularly towards the apex; stigma bilobed, c. $1 \mathrm{~mm}$ across. Fruits ovoid or rather elongate, glabrous, somewhat verrucose, drying dark brown, 11-15 × 4-7 mm; base of style and calyx persistent.

Distribution. Central Sulawesi (see Figure 29).

Habitat and ecology. Hill forest at an altitude of 660-680 m.

Etymology. Named after Hendrian, Director of Bogor Botanic Garden and also one of the collectors of this species (Kartonegoro et al., 2018).

Proposed IUCN conservation category. It has not been possible to calculate an EOO for Cyrtandra hendrianii because of the low number of collections, but it has an AOO of $4 \mathrm{~km}^{2}$, based on a $2 \times 2 \mathrm{~km}$ grid cell size, under the B criteria (Bachman et al., 2011). The species is known only from Mount Hek, where it was collected at relatively low altitude during an expedition in 2004. This forest type is one of the most threatened in Sulawesi (Cannon et al., 2007), and Mount Hek is in an area with no formal protection (UNEPWCMC \& IUCN, 2019). It is, however, in one of the most under-collected areas of Sulawesi (Kessler et al., 2002; Cannon et al., 2007), therefore there may be more populations of this species. In view of its narrow distribution in a single location in a threatened forest type and with no formal protection, Cyrtandra hendrianii is assessed as Critically Endangered (CR), B2ab(iii).

Additional specimen examined. INDONESIA. Central Sulawesi. Banggai: Mt Hek, Sungai Spa, 25 ii 2004, Scott 04-316, grown at RBGE as accession 20040646A, vouchered as Scott 503 (E).

Cyrtandra hendrianii is most similar to $C$. albiflora collected from the same location. It can be distinguished, however, by its pink corolla and red calyx (versus white corolla and green calyx), more or less glabrous stems (versus densely villous stems), and oblong-lanceolate bracts, 25-35 mm long (versus linear-lanceolate bracts $10-11 \mathrm{~mm}$ long).

15. Cyrtandra hispidula Karton. \& H.J.Atkins, Edinburgh J. Bot. 75(2): 187 (2018). - Type: Indonesia, Sulawesi, South Sulawesi, Mt Rantemario, 25 iv 2009, Thomas \& Ardi 09-86 (holotype BO; isotypes E, L). Figure 28.

Coarse herb to $1.5 \mathrm{~m}$ in height. Stems ridged, striate, green, densely hairy on young growth and around axils, hairs coarse, pale, 1-3.5 mm long. Leaves opposite, subequal, drying dark brown; petioles green, $2.5-5.5 \mathrm{~cm}$ long, densely hairy; blades $14-16 \times 9-10 \mathrm{~cm}$, wide 


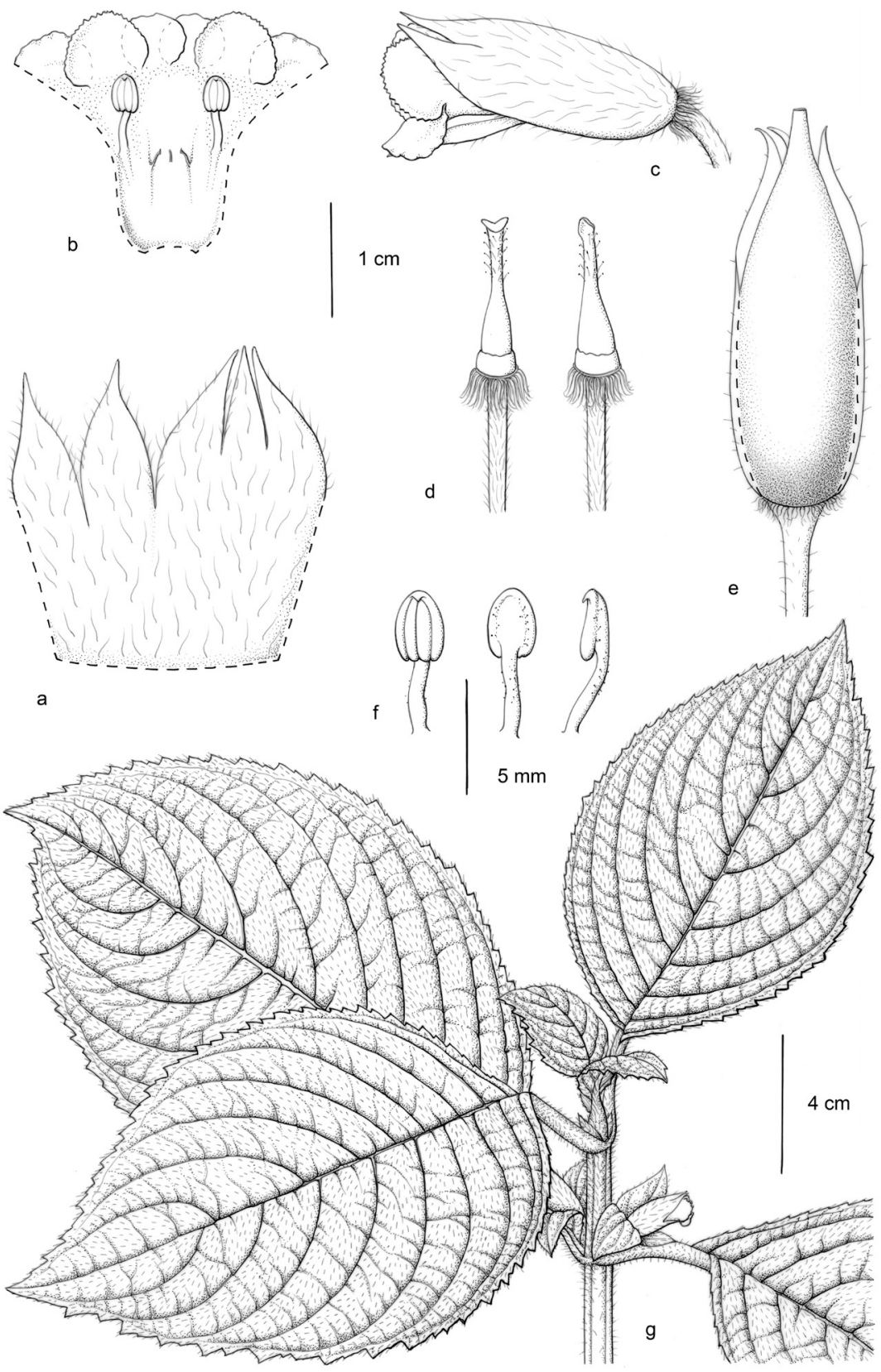

Figure 28. Cyrtandra hispidula. a, Opened calyx, showing outer surface; b, opened corolla, showing position of stamens and staminodes; $c$, side view of corolla; $d$, gynoecium including disc and top of pedicel; e, fruit with persistent calyx partially removed; $f$, anthers; $g$, habit. Drawn by Claire Banks from Thomas \& Ardi 09-86. Reproduced from Kartonegoro et al. (2018) with the permission of the Trustees of the Royal Botanic Garden Edinburgh. 
elliptic to ovate, base obtuse slightly asymmetrical, margin serrate, apex acuminate; 8 or 9 pairs of lateral veins and reticulate tertiary venation, dark glossy green, slightly marbled with scattered, long hairs above, densely hairy on midrib and veins below. Inflorescences axillary, subsessile, 1- or 2-flowered; peduncle up to $5 \mathrm{~mm}$ long, densely hairy; bracts green, 25-40 $\times 8-20 \mathrm{~mm}$, paired, leaf-like, broad elliptic to ovate, with a covering of dense, coarse white hairs, especially on veins, margins serrate, apex acute; pedicels green, 13-15 mm long, hairy, continuing to elongate up to $40 \mathrm{~mm}$ with the developing fruit. Calyx tubular, green, c. $25 \mathrm{~mm}$ long, lobes acuminate, lower lobes c. $10 \mathrm{~mm}$ long, upper lobes c. $8 \mathrm{~mm}$ long, hairy, densely so at the base with a distinctive fringe of hairs. Corolla white, turning brown with time, tube completely enclosed within calyx, only lobes visible, c.18 mm long, tube glabrous externally and with a scattering of small glands in the mouth of the corolla, all lobes rounded, lateral lobes with shallowly serrate margins, upper lobes 5-6 $54 \mathrm{~mm}$, lower and lateral lobes c. $8 \times$ $5 \mathrm{~mm}$. Stamens with filaments c. $3 \mathrm{~mm}$ long, attached c. $8 \mathrm{~mm}$ above the base of the corolla, straight, almost glabrous, with a few scattered, glandular hairs; anthers c. $3 \mathrm{~mm}$ long, with stalked glandular hairs on the back, not coherent; staminodes 3, c. $2 \mathrm{~mm}$ long. Gynoecium c. $12 \mathrm{~mm}$ long; disc cupular with undulate margin, c. $2 \mathrm{~mm}$ long, glabrous; ovary glabrous; style with some glandular hairs, particularly towards the apex; stigma bilobed, c. $1 \mathrm{~mm}$ across. Fruits oblong, glabrous, smooth, green, drying dark brown, 18-25 × 5-8 mm; calyx and base of style persistent.

Distribution. South Sulawesi: Latimojong Range (Figure 29).

Habitat and ecology. Montane forest at an altitude of c. $2500 \mathrm{~m}$.

Etymology. Named after its distinctive hispid indumentum on most parts of the plant (Kartonegoro et al., 2018).

Proposed IUCN conservation category. It has not been possible to calculate EOO for Cyrtandra hispidula because of the low number of collections, but the AOO is $4 \mathrm{~km}^{2}$, based on a $2 \times 2 \mathrm{~km}$ grid cell size, under the B criteria (Bachman et al., 2011). It is found in montane forest, which is not considered to be under threat, with a substantial majority of these sites across the island still in good condition (Cannon et al., 2007). Following Kartonegoro et al. (2018), a category of Least Concern (LC) is proposed for this species because of the lack of perceived threat.

Additional specimen examined. INDONESIA. South Sulawesi. Enrekang: Latimojong Mountains, Mt Batutoding, 1913, Rachmat 916 (BO).

The combination of coarse, hispid, white indumentum, broad leaves and large, leaf-like inflorescence bracts distinguishes Cyrtandra hispidula from any other Cyrtandra species on the island. 


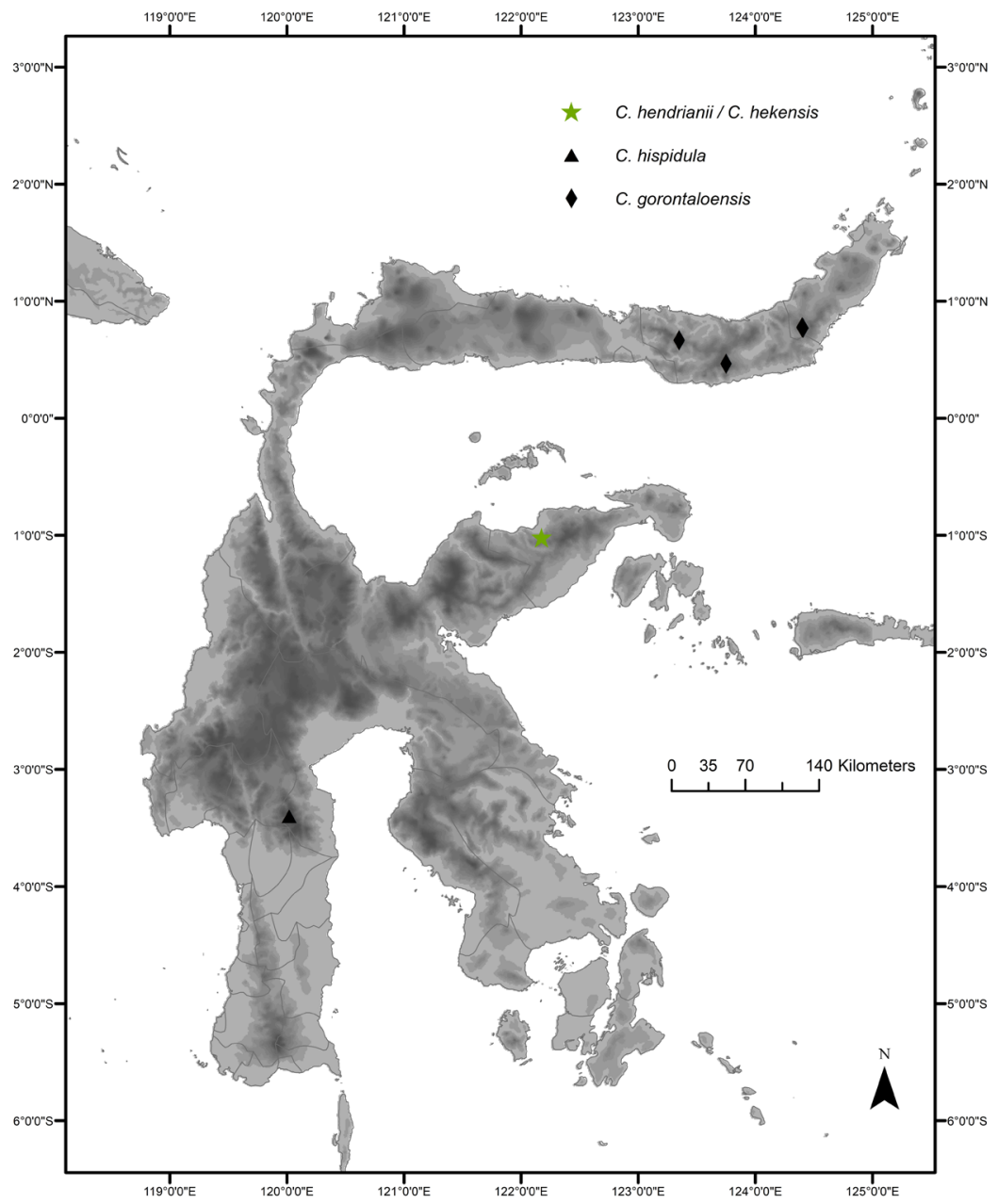

Figure 29. Distribution of Cyrtandra gorontaloensis (black diamonds), C. hekensis and C. hendrianii (green star) and C. hispidula (black triangle).

16. Cyrtandra hypogaea Koord., Meded. Lands Plantentuin 19: 628 (1898). - Type: Indonesia, Celebes [Sulawesi], Mt Lolombulan, 9 iv 1897, Koorders 17190ß (lectotype BO, designated here; isolectotype L). Figure 30.

Branching herb or shrub to $2 \mathrm{~m}$ in height, rarely epiphytic (de Vogel 2649). Stems striate, subglabrous, hairy on young growth, woody at base. Leaves opposite; both members of a pair well developed but somewhat unequal in size; petiole $10-35 \mathrm{~mm}$ long, hairy to densely hairy; blades (5-) $10-25 \times(1.5-) 3.5-6 \mathrm{~cm}$, usually narrow obovate, sometimes narrow oblong or oblanceolate, base acute, briefly decurrent, slightly asymmetrical, margin serrulate to serrate, apex acuminate; $5-7(-8)$ pairs of lateral veins, curving upwards and running 

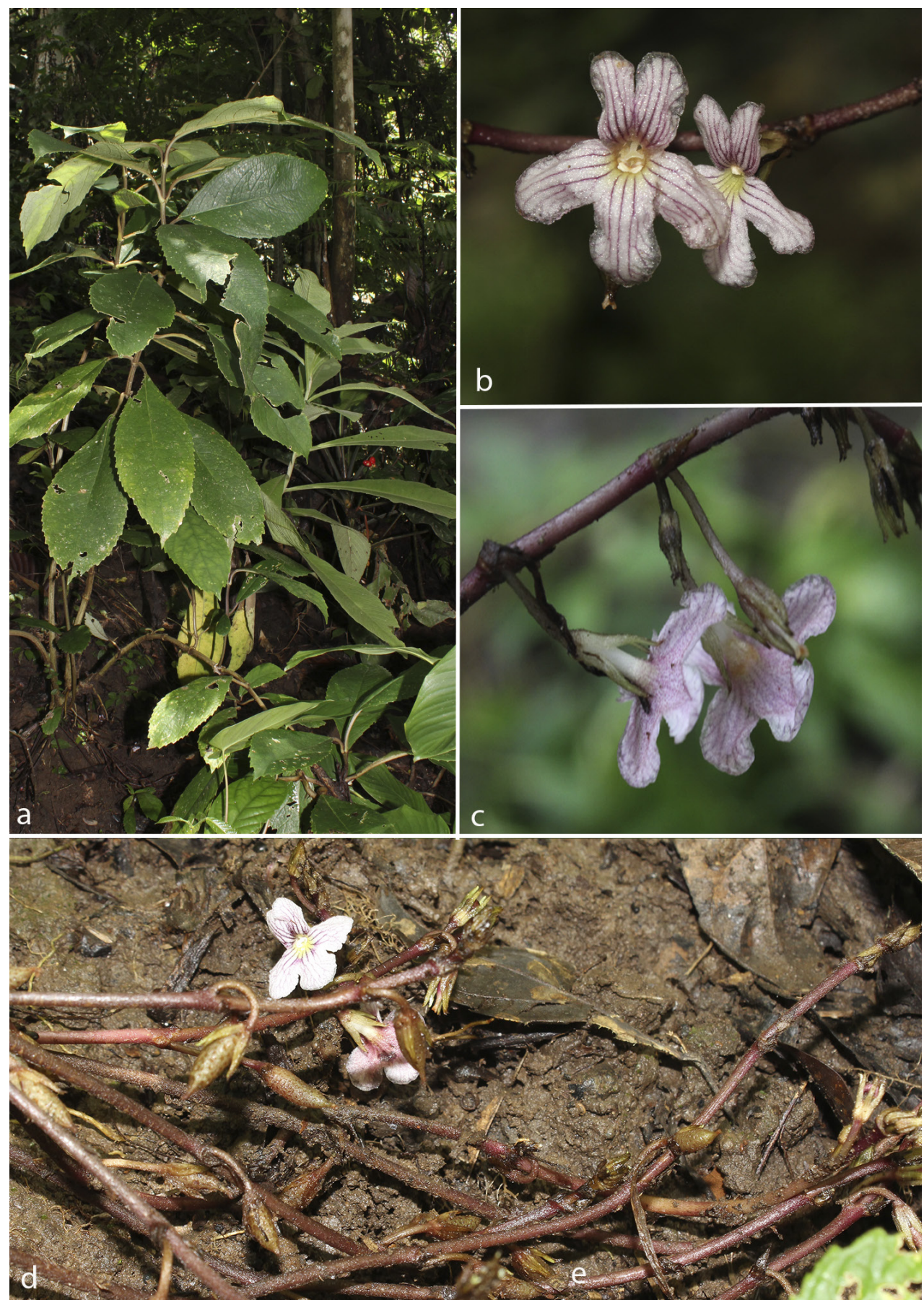

Figure 30. Cyrtandra hypogaea. a, Habit; b, front view of flowers; c, side view of flowers; $d$, trailing inflorescence. Photographs: Sadie Barber. Specimen: Barber et al. BAKK30. 
out to margin, sometimes with short lateral veins running out to adjacent teeth, sparsely hairy above, hairy below, more densely so on midrib, veins and margins. Inflorescences trailing from base of main plant; trailing inflorescence axis 2-3 $\mathrm{mm}$ in diameter, up to $2 \mathrm{~m}$ long, glabrous, usually appearing 'notched' from the remnants of old bracts; bracts $3-5 \times$ 1-2 mm, ovate, acuminate at apex, hairy, not connate, caducous. Calyx purple or reddish, 6-10 mm long, evenly 5-lobed or bilabiate with three lobes joined to halfway, lobes linear, 6-8 mm or divided briefly at apex, hairy externally. Corolla white flushed pink with deep-red guidelines and light yellow or orange in the throat or, rarely, bright red with (or without) yellow in the throat, 8-15 mm long, more or less parallel-sided, widening at mouth, lobes not recurved, lobes 3-4 × 2-3 mm, hairy externally. Stamens with filaments 1-2 mm long, attached 4-7 mm from base of corolla; anthers $1 \mathrm{~mm}$ long, connected at apices before dehiscence; staminodes 3, laterals c. $1 \mathrm{~mm}$ long, central c. $0.5 \mathrm{~mm}$ long. Gynoecium 4-7(-10) mm long; disc unilateral with undulate to lobed margin, 1-2 mm long, glabrous; ovary subglabrous to sparsely hairy; style eglandular hairy for whole length; stigma bilobed, lobes vertical, 1-2 mm long, densely glandular on inner surface of lobes. Fruits ovoid to narrow ovoid, green when unripe, sometimes recorded as turning reddish, glabrous, distinctively tessellate when dried, $9-12(-15) \times 2-5 \mathrm{~mm}$, calyx and base of style usually persistent.

Distribution. North Sulawesi, Gorontalo, Central Sulawesi, West Sulawesi, South Sulawesi, Southeast Sulawesi (see Figure 31).

Habitat and ecology. Lowland, Hill and Upland Forest at an altitude of 50-1290 m.

Etymology. The epithet of this species refers to the position of the flowers near the ground (Koorders, 1898).

Proposed IUCN conservation category. The EOO of Cyrtandra hypogaea is $173,191 \mathrm{~km}^{2}$ and the AOO is $112 \mathrm{~km}^{2}$, based on a $2 \times 2 \mathrm{~km}$ grid cell size, under the B criteria (Bachman et al., 2011). This is one of the most common and widespread species on the island, collected in all of the six provinces in Sulawesi and over a wide altitudinal range, and for this reason is considered to be of Least Concern (LC).

Additional specimens examined. INDONESIA. North Sulawesi. Bolaang Mongondow: Kasingolan River, 30 xi 2016, Barber, Atkins, Kartonegoro \& Kinho BAKK17 (BO, E); Mt London, 31 xi 2016, Barber, Atkins, Kartonegoro \& Kinho BAKK30 (BO, E); Dumoga Bone [Bogani Nani Wartabone] National Park, 28 iii 1985, de Vogel \& Vermeulen 6786 (E, L); North Minahasa: South part of Wiau forest reserve, base of Mt Klabat, 1 xi 1973, de Vogel 2649 (BO, CANB); Tomohon: Wagio crater, Mt Mahawu, 4 vii 1956, Forman 393 (BO, L); Mt Mahawu, 15 ii 2009, Girmansyah 1257 (BO).

Gorontalo. Bone Bolango: Route along the Olama River to Mt Gambuta, 9 iv 2002, Scott 02-42, grown at RBGE as accession 20021875A, vouchered as Atkins 46 (E).

Central Sulawesi. Banggai: inland from Batui, 17 x 1989, Coode 5983 (A, BO, K, L, SING); Bunta Subdistrict, Sumber Agung, Mt Hek, 26 ii 2004, Hendrian, Newman, Scott, Saleh \& Supriadi 900 (E); 
Luwuk District, Bunta Subdistrict, Sumber Agung, Mt Hek, 26 ii 2004, Scott 04-329, grown at RBGE as accession 20040647A, vouchered as Scott 449 (E); Parigi Moutong: Pangi Binangga, Uwe Lutu, CA, 20 vii 2018, Ardi WI209 (KRB); Between Palu and Parigi, 35 km from Palu, 7 iv 1975, Meijer 9342 (BO, L); Poso: Danau Poso, Tentena-bancea road divide, 2 viii 2018, Ardi WI277 (KRB); Pass between Lake Poso and Wotu, 2 iii 2000, Mendum, Argent \& Hendrian 00220 (BO, E); Sigi: Mt Nokilalaki, track to shelter 2, 24 vii 2018, Ardi WI222 (KRB); ibid., 24 vii 2018, Ardi WI230 (KRB); Upper Sopu River, E. end of Sopu Valley, 5 v 1979, van Balgooy 3501 (L); Danau Tambing, 23 v 1979, van Balgooy 3434 (BO, E, L); Mt Nokilalaki, 10 vii 1939, Bloembergen 4029 (BO, L); Lore Lindu National Park, Ponoh, 3 km NE of Toro Village, 17 xii 2007, Cicuzza 620 (E); Lore Lindu, Mt Nokilalaki, 6 iii 2008, Cicuzza 793 (E); Lore Lindu National Park, Ponoh, 3 km NE of Toro Village, 10 iv 2008, Cicuzza 1016 (E); Sopu Valley, c.80 km s. of Palu, 6 v 1979, Hennipman 5621 (BO, E); W of Tongoa, 6 iii 1981, Johansson, Nybom \& Riebe 195 (L); Mt Roroka Timbu, 11 v 1979, de Vogel 5296 (L); ibid., 11 v 1979, de Vogel 5315 (L); Sopu valley c. 80 km SSE of Palu, 26 v 1979, de Vogel 5578 (BO, L); Toli-Toli: Mt Dako, Teluk Bone, Lakatan, 24 iii 1985, Ramlanto \& Zainal Fanani 513 (BO).

West Sulawesi. Mamasa: Mt Gandang Dewata, 20 iv 2016, Kartonegoro, Ardiyani, Santoso, Wardani ARK904 (BO, E).

South Sulawesi. East Luwu: Mt Wawonseru, SW of Soroako, 3 vi 1979, Hennipman 5994 (BO, E); Kawata, 18 ix 1929, Kjellberg 2334 (BO, S).

Southeast Sulawesi. Selewar, Preko, 5 x 1929, Kjellberg 2498 (BO, S); North Kolaka: Bulu Porema, 27 x 1929, Kjellberg 2664 (BO, S); Rante Angin subdistrict, Tinukari village, 30 vi 2011, Widjaja, Sujadi, Santoso \& Hapid EAW9713 (BO); Tinukari village, 30 vi 2011, Widjaja, Sujadi, Santoso \& Hapid EAW9717 (BO).

Cyrtandra hypogaea can be easily distinguished from other species on Sulawesi with trailing inflorescences by a thicker, and usually more notched, inflorescence axis 2-3 mm in diameter, smaller flowers, and a unilateral disc. The fruits also have a distinct, tessellate appearance when they are dried.

Koorders did not specify a type when he described this species. Therefore, the most complete of Koorders own collections, Koorders $17190 \beta$ in the herbarium in Bogor (BO), annotated by him with the name Cyrtandra hypogaea and with an illustration attached, has been selected as the lectotype.

There are three collections from the Lore Lindu area of Central Sulawesi, namely Ardi WI230, van Balgooy 3434 and de Vogel 5315, which are recorded as having a red corolla, sometimes with yellow markings on the lower lobes. The phenomenon of colour variation, although very rare in Cyrtandra, has been seen in C. splendens C.B.Clarke from Borneo. In that case, the corolla, usually white or cream-coloured with a large crimson patch on each lobe, was found in one or two populations to have a wholly red corolla (Burtt, 1990). These red-flowered specimens fall within the distribution range of Cyrtandra hypogaea. The collections also bear some resemblance, particularly in the striking red corolla colour, to the closely related Cyrtandra rantemarioensis from the Latimojong Range in South Sulawesi but can be separated from that species geographically and also by ovary indumentum, leaf decurrence and fruit shape. Further collections are required to confirm the status of these collections, but for now they are treated as Cyrtandra hypogaea. 
17. Cyrtandra jellesmanii Koord., Meded. Lands Plantentuin 19: 628 (1898) [jellesmani]. Type: Indonesia, Celebes [Sulawesi], North Sulawesi, Minahasa, Pinamorongan camp, 26 i 1895, Koorders $17193 \beta$ (lectotype BO [BO-1454372], designated here; isolectotype BO [BO-1454373]).

Herb to $30 \mathrm{~cm}$ in height. Stems striate, sparsely hairy, more densely so on young growth. Leaves opposite; both members of a pair well developed but unequal in size; blades 4-14 $\times 1.5-3.5 \mathrm{~cm}$, oblanceolate to narrow oblanceolate, base decurrent, margin crenateserrulate, apex shortly acuminate; 3-5 pairs of lateral veins, curving upwards and running out to margin, glabrous above, sparsely hairy below, more densely so on midrib and veins. Inflorescences axillary, sessile, 1-flowered; bracts 8-10 × $1 \mathrm{~mm}$, linear, hairy, not connate; pedicels c. $1 \mathrm{~mm}$ long, hairy. Calyx $12-15 \mathrm{~mm}$ long, 2-lobed, lobes triangular, acuminate at apex, 7-8 mm long, hairy externally. Corolla white, c. $45 \mathrm{~mm}$ long, funnel-shaped, lobes not strongly recurved, lower lobes up to $11 \times 10 \mathrm{~mm}$, upper lobes $10 \times 9 \mathrm{~mm}$, hairy externally. Stamens with filaments c. $11 \mathrm{~mm}$ long, attached c. $25 \mathrm{~mm}$ above base of corolla, glabrous; anthers 1.5-2 mm long, connected at apices and face to face before dehiscence; staminodes not seen. Gynoecium c. $25 \mathrm{~mm}$ long; disc c. $1 \mathrm{~mm}$ long, cupular with lobed margin, glabrous; ovary eglandular hairy, glabrous towards base; style densely eglandular hairy for whole length; stigma peltate, c. $2 \mathrm{~mm}$ across. Fruits not seen.

Distribution. North Sulawesi (Figure 31).

Habitat and ecology. Lowland and hill forest at an altitude of 500-600 m.

Etymology. This species was named after Mr Jellesman, a resident of Manado whom Koorders visited in 1895 (Koorders, 1898).

Proposed IUCN conservation category. The low number of collections means that an EOO for this species could not be calculated, but the $A O O$ is $8 \mathrm{~km}^{2}$, based on a $2 \times 2 \mathrm{~km}$ grid cell size, under the B criteria (Bachman et al., 2011). Cyrtandra jellesmanii is known only from two collections from North Sulawesi, made in 1895 and 1917. We returned to the collection localities in 2016 and were unable to find any populations. Lowland and hill forest are the most threatened forest types on the island (Cannon et al., 2007), and much of the forest surrounding the type locality is now gone. For these reasons, this species is considered to be Critically Endangered (CR), B2ab(iii).

Additional specimen examined. INDONESIA. North Sulawesi. Minahasa: Gurupahi, 15 iv 1917, Kaudern 46 $(\mathrm{L}, \mathrm{S})$.

Cyrtandra jellesmanii is a distinctive species, with its oblanceolate leaves and large, funnel-shaped flowers. The sheet in the Bogor herbarium of Koorders' only collection, Koorders $17193 \beta$, which is annotated with full collection details, is designated here as the lectotype. It has the name 'Cyrtandra jellesmaniana' written on the label, but the 


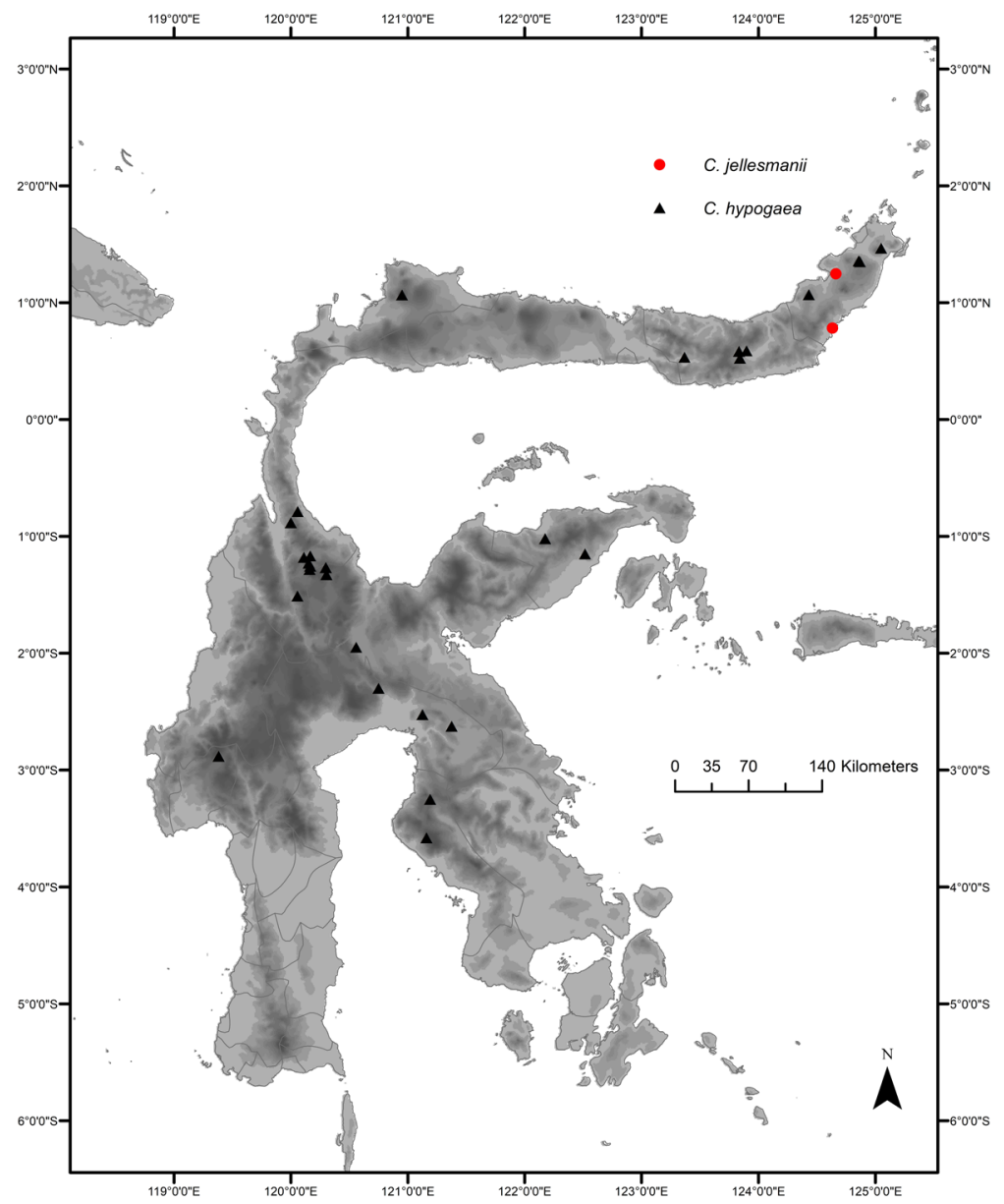

Figure 31. Distribution of Cyrtandra hypogaea (black triangles) and C. jellesmanii (red circles).

original publication has the spelling 'C. jellesmani' (Koorders, 1898), corrected here to C. jellesmanii following Article 60.8(b) of the International Code of Nomenclature (Turland et al., 2018).

18. Cyrtandra kinhoi Karton. \& H.J.Atkins, Edinburgh J. Bot. 75(2): 190 (2018) [kinhoii]. Type: Indonesia, Sulawesi, North Sulawesi, Mt Ambang Nature Reserve, Paya Paya, near Sinsingon village, 2 xi 2016, Barber, Atkins, Kartonegoro \& Kinho BAKK36 (holotype BO; isotypes E, L). Figure 32.

Shrub 1-3 m or small tree 6-7 $\mathrm{m}$ in height. Stems tessellate, glabrous, sparsely hairy on younger growth, woody. Leaves opposite; subequal to somewhat unequal; petioles $1.5-2 \mathrm{~cm}$ long; blades 30-60 × 10-15 cm, narrow elliptic or narrow obovate to oblanceolate, usually crowded at the ends of branches, rarely obtuse, base decurrent, margin serrate, apex 

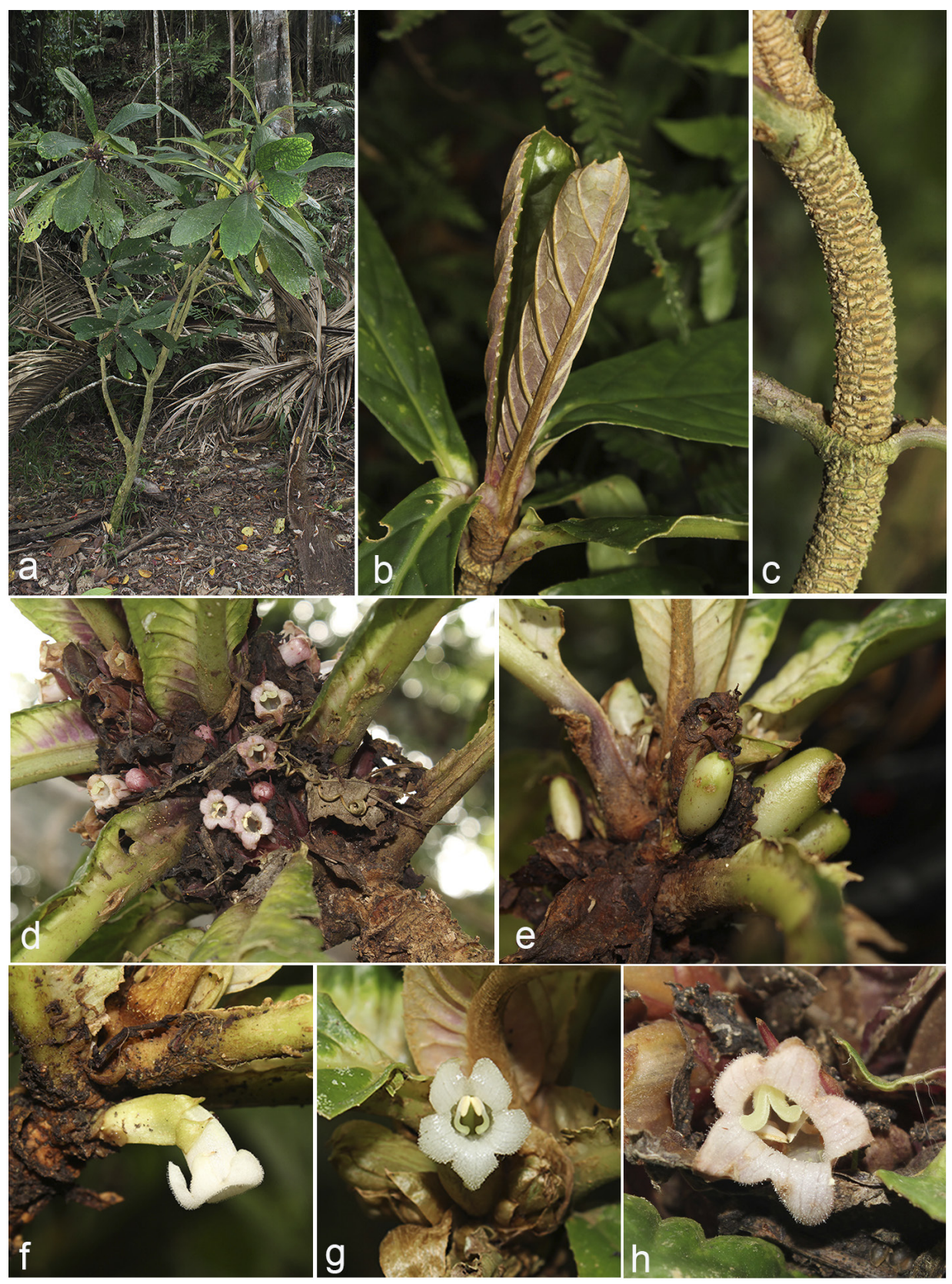

Figure 32. Cyrtandra kinhoi. a, Habit; b, young leaves; c, tessellate stem; $d$, inflorescence; e, infrutescence; $f$, side view of flower; $g$, front view of young flower; $h$, front view of older flower with stamens recoiled and stigma exposed. Photographs: Sadie Barber. Specimens: Barber et al. BAKK36 and BAKK65. Reproduced from Kartonegoro et al. (2018) with the permission of the Trustees of the Royal Botanic Garden Edinburgh. 
short-acuminate; 10-20 pairs of lateral veins and reticulate tertiary venation, curving upwards and running out to the margin, occasionally branching near the margin, glabrous, midgreen above, sparsely hairy and paler green below, more densely hairy on midrib and veins and occasionally flushed red at base of leaf. Inflorescences axillary, sessile, congested, with up to c.15 flowers at various stages of development; bracts oblong-lanceolate, light green, flushed slightly reddish, leathery, 30-45 × 20-25 mm, subglabrous to sparsely hairy, slightly warty, apex acute or short-acuminate, caducous; bracteoles lanceolate, light green, subglabrous c. $3 \times 1 \mathrm{~cm}$, leathery, apex acuminate; pedicels 4-7 mm long, light green, glabrous to sparsely hairy. Calyx tubular, 21-25 mm long, light green to dark reddish brown, sparsely hairy, warty at base, lobes acuminate, lower lobes divided c.12 mm from apex, upper lobes less deeply divided, 8-10 mm from apex, densely hairy. Corolla white or flushed slightly pink, $30-35 \mathrm{~mm}$ long, narrow in basal $1 / 3$ to $1 / 2$, gradually widening to mouth, glandular hairy on outer surface, densely so on inner surface, lobes strongly recurved, upper lobes rounded, $6 \times 5 \mathrm{~mm}$, lower and lateral lobes rounded to slightly oblong, 5-10 $\times 5-7 \mathrm{~mm}$, lobes with dense covering of glandular hairs. Stamens with filaments 2-8 $\mathrm{mm}$ long, attached $12-20 \mathrm{~mm}$ above the base of corolla, glabrous, light green; anthers 2-3 mm long, coherent at apices, cream; staminodes 3 , laterals c. $1.5 \mathrm{~mm}$ long, central c. $0.5 \mathrm{~mm}$ long. Gynoecium 25-30 mm long; disc cupular with undulate margin, lower on one side, glabrous, 2-3 mm long; ovary glabrous; style white, glabrous, becoming slightly hairy towards apex on some collections; stigma light green, bilobed, lobes 3-4 × 2-3 mm across, vertical or spreading, densely glandular hairy on inner surface of lobes. Fruits ovoid, glabrous, $10-15 \times 5-8 \mathrm{~mm}$, green when unripe; bracts and calyx not persistent, base of style occasionally persistent.

Distribution. North Sulawesi and Gorontalo (see Figure 35).

Habitat and ecology. Hill and upland forest at an altitude of 700-1300 m.

Etymology. Named after Julianus Kinho, researcher at the Forestry Research Institute of Manado, North Sulawesi and one of the collectors of the type specimen (Kartonegoro et al., 2018).

Proposed IUCN conservation category. Based on the current distribution of Cyrtandra kinhoi, now confined to the northern arm of Sulawesi, its EOO is $4053 \mathrm{~km}^{2}$ and its AOO is $32 \mathrm{~km}^{2}$, based on a $2 \times 2 \mathrm{~km}$ grid cell size, under the B criteria (Bachman et al., 2011). Some of the collection localities fall within the Bogani Nani Wartabone National Park and the Mount Ambang Nature Reserve (UNEP-WCMC \& IUCN, 2019), which provide their populations with some protection, but the remaining populations are from the more densely populated areas around Menado and Tomohon. Given the restricted distribution of Cyrtandra kinhoi and its proximity to some of the more heavily populated areas of Sulawesi, this species is considered Vulnerable (VU), B1ab(iii) + 2ab(iii). 
Additional specimens examined. INDONESIA. North Sulawesi. East Bolaang Mongondow: Mt Ambang, 3 xi 2016, Barber et al. BAKK65 (BO, E); Minahasa: Mt Masarang, 10 i 1895, Koorders 17187 $\beta$ (BO, L); South Minahasa: Mt Manimporok, Soputan Mts, 18 vi 1954, Alston 15926 (BM, BO); Lolombulan, 6 iv 1895, Koorders $17191 \beta$ (BO, L); Tomohon: Mt Mahawu, 23 vi 1956, Forman 223 (BO, K, L); ibid., 14 ii 2009, Girmansyah 1215 (BO).

Gorontalo. Bone Bolango: Mt Gambuta, 10 iv 2002, Atkins et al. 56 (BO, E).

Cyrtandra kinhoi is similar vegetatively to $C$. fasciata, $C$. flavomaculata and C. longistamina in having decurrent leaves and tessellate stems. It can be distinguished most easily from Cyrtandra fasciata by its larger inflorescence bracts ( $25 \mathrm{~mm}$ wide as opposed to $2 \mathrm{~mm}$ wide) and from $C$. longistamina by its ovoid fruits on short pedicels up to $7 \mathrm{~mm}$ long (as opposed to subglobose fruits on pedicels up to $30 \mathrm{~mm}$ long).

When this species was first described (Kartonegoro et al., 2018), three outlier collections from Lore Lindu in Central Sulawesi were highlighted as having a different style indumentum. Recent collections accompanied by photographs from Lore Lindu have provided further information, and it is now clear that these collections represent a different species, Cyrtandra flavomaculata, described here. The new species can be distinguished from Cyrtandra kinhoi by its corolla, which is funnel-shaped (as opposed to tubular), white with large yellow markings on its upper and lower lobes (as opposed to white or flushed pink without markings), and densely hairy (not glabrous) style. The young leaves of Cyrtandra kinhoi are collected and used as a vegetable (H. J. Atkins \& A. Kartonegoro, personal observations).

The original publication has the spelling 'Cyrtandra kinhoii' (Kartonegoro et al., 2018). This has been corrected here to Cyrtandra kinhoi, following Article 60.8(a) of the International Code of Nomenclature (Turland et al., 2018).

19. Cyrtandra kjellbergii R.Bone \& H.J.Atkins, Edinburgh J. Bot. 70(3): 460 (2013) - Type: Indonesia, Sulawesi, South Sulawesi, B. Poka Pinjang, 27 v 1929, Kjellberg 1459 (holotype BO, isotype S). Figure 33.

Shrub (height not recorded). Stems glabrescent, densely hairy when young. Leaves usually strongly anisophyllous but occasionally with both members of a pair well developed but somewhat unequal in size; petiole 4-6 mm long, sparsely hairy; blades of larger leaf, 4-6 $\times$ 2-3 cm, elliptic to narrow obovate, base acute, margin serrate with c.3-7 serrations along each side, sparsely ciliate, apex acuminate; 4 or 5 pairs of lateral veins, upper surface very sparsely hairy, lower surface sparsely hairy on primary and secondary veins, glabrescent between veins. Inflorescences sessile in leaf axils or at the base of plant, 1- or 2-flowered; bracts c. $2 \mathrm{~mm}$ long, often caducous, elliptic to ligulate, hairy; pedicels 5-10 mm long, sparsely hairy. Calyx 6-11 mm long; lobes caudate, 2-5 mm long, hairy externally. Corolla yellow, c.28 mm long, tube narrow, more or less parallel-sided, widening slightly towards mouth, lobes oblong, $5 \times 3-4.5 \mathrm{~mm}$, hairy on outer surface, glabrous on inner surface with 


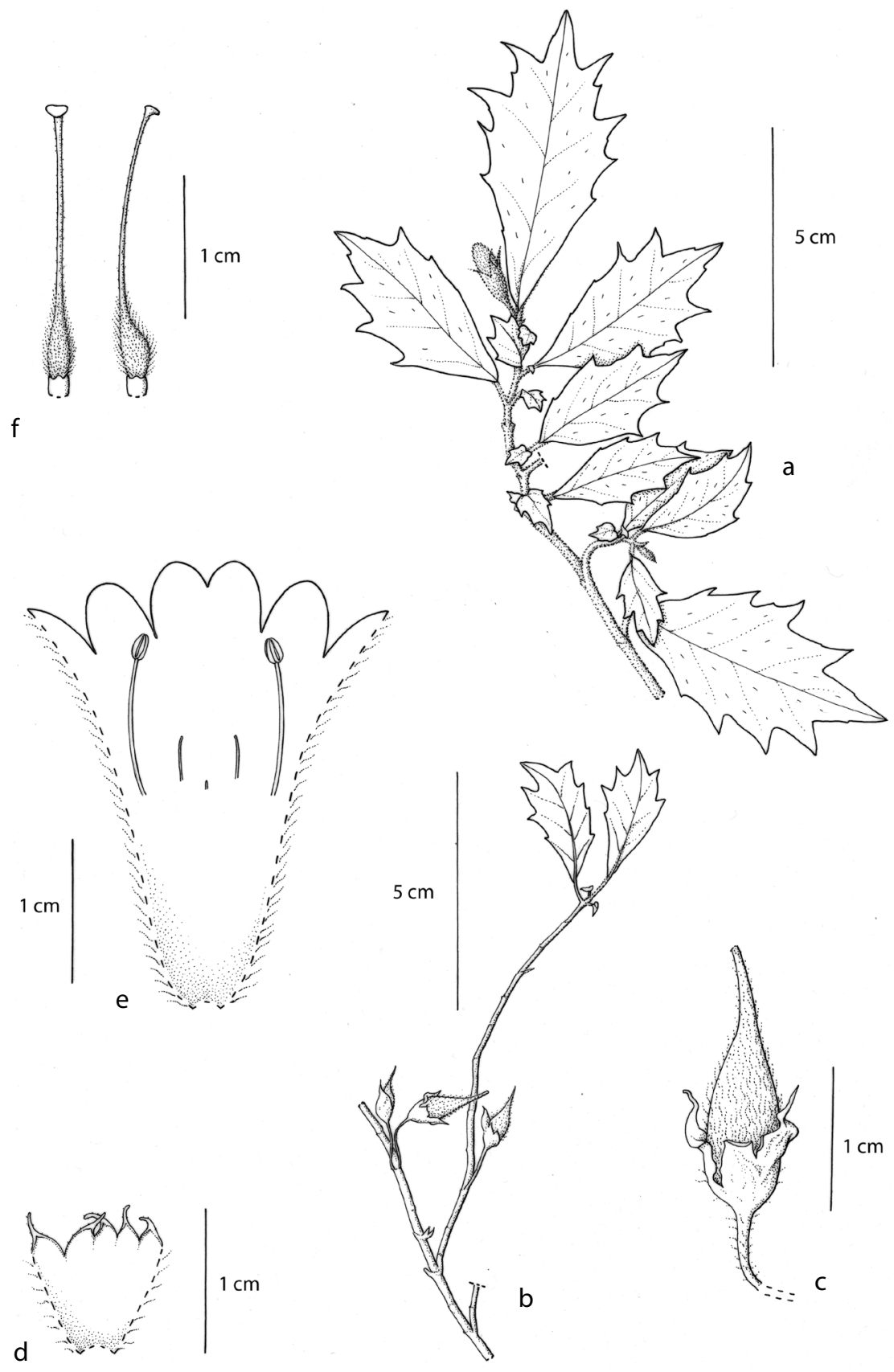

Figure 33. Cyrtandra kjellbergii. a, Habit; b, fruits on stem; c, fruit and calyx; d, opened calyx, showing inner surface; e, opened corolla, showing position of stamens and staminodes; $f$, gynoecium and disc. Drawn by Claire Banks from Kjellberg 1459. Reproduced from Bone \& Atkins (2013) with the permission of the Trustees of the Royal Botanic Garden Edinburgh. 
some glandular hairs at base of lobes. Stamens with filaments 9-10 mm long, attached c. $17 \mathrm{~mm}$ from base of corolla, glabrous; anthers 1-1.5 mm long; staminodes 3 , lateral staminodes c. $3 \mathrm{~mm}$ long, central one highly reduced, glabrous. Gynoecium 16-20 mm long; disc cupular, undulate, c. $1 \mathrm{~mm}$ long, glabrous externally; ovary densely hairy; style glabrescent to sparsely glandular hairy; stigma capitate, c. $1 \mathrm{~mm}$ across, papillose. Fruits ovoid, $12-13 \times 4-5 \mathrm{~mm}$, sparsely hairy, calyx and base of style persistent.

Distribution. South Sulawesi, Latimojong Range (see Figure 35).

Habitat and ecology. Montane forest at an altitude of $2300 \mathrm{~m}$.

Etymology. This species is named after Gunnar Konstantin Kjellberg (1885-1943) who made an important botanical investigation of Sulawesi in 1929 (Bone \& Atkins, 2013).

Proposed IUCN conservation category. Cyrtandra kjellbergii is known only from one location, so it has not been possible to calculate an EOO but it has an AOO of $4 \mathrm{~km}^{2}$, based on a $2 \times$ $2 \mathrm{~km}$ grid cell size, under the B criteria (Bachman et al., 2011). The species is known only from the type location, from where it was collected in 1929 at $2300 \mathrm{~m}$ a.s.l. The collection locality is in neither a protected area nor a national park (UNEP-WCMC \& IUCN, 2019); however, the collection is from montane forest, which is one of the least threatened forest types on the island (Cannon et al., 2007). A category of Least Concern (LC) is assigned for this species because there is no evidence of threat, but the importance of further collecting in this area is emphasised.

Cyrtandra kjellbergii is known only from the type collection. This species is similar in overall appearance to Cyrtandra balgooyi from Central Sulawesi. It can be distinguished by its leaf margin (serrate but with only c.4-7 deep serrations along leaf margin versus serrate with many serrations along leaf margin), corolla size (28 mm versus $20 \mathrm{~mm}$ long) and style indumentum (glabrescent to sparsely glandular hairy versus densely eglandular hairy). It is also currently known only from the Latimojong Mountains, whereas Cyrtandra balgooyi is restricted to the environs of the Lore Lindu National Park in Central Sulawesi.

20. Cyrtandra longirostris de Vriese, PI. Ind. Bat. Orient., 12 (1856). - Rhynchocarpus longirostris Reinwardt ex de Vriese, PI. Ind. Bat. Orient. 12 (1856), nom. inval. - Type: Indonesia, Celebes [Sulawesi], North Sulawesi, in monte Lujong insulae, Reinwardt (mss no. 1515) 1535 (lectotype L [L0277503], designated here; isolectotype S).

Shrub to $2 \mathrm{~m}$ in height. Stems striate, hairy, more densely so on young growth, woody at base. Leaves opposite, both members of a pair well developed but somewhat unequal in size; petiole 5-15 mm, hairy; blades 7-19 × 2.5-7 cm, elliptic to narrow elliptic, sometimes narrow obovate, base acute, briefly decurrent, slightly asymmetrical, margin subentire to serrulate, apex acuminate; 6-8 pairs of lateral veins curving upwards and running out to margin, sparsely hairy above and below, more densely so on midrib and veins below. 
Inflorescences axillary, pedunculate, 2- or 3-flowered; bracts 2-3 $\times 1-2 \mathrm{~mm}$, lanceolate, hairy, not connate; peduncles $15-40 \mathrm{~mm}$ long, sparsely hairy to hairy; pedicels $8-12 \mathrm{~mm}$ long, sparsely hairy. Calyx 7-9 mm, evenly 5-lobed, rarely 4-lobed, lobes triangular, acuminate at apex, 4-6 mm long, hairy externally. Corolla white or light yellow, 11-17 mm long, tube narrow in basal half, widening abruptly to mouth in apical half, lobes not recurved, upper lobes $4 \times 3-5 \mathrm{~mm}$, lower lobes c. $6 \times 3 \mathrm{~mm}$, hairy externally. Stamens with filaments $2-3 \mathrm{~mm}$ long, attached 5-8 $\mathrm{mm}$ from base of corolla, glabrous; anthers $\mathrm{c} .1 \mathrm{~mm}$ long, connected at apices before dehiscence; staminodes 1-2 mm long. Gynoecium 8-10 mm long; disc cupular, margin undulate, c. $1 \mathrm{~mm}$ long, glabrous externally; ovary glabrous; style glabrous towards the base, becoming glandular hairy at the top of the style near the stigma; stigma slightly bilobed, lobes almost triangular, $1 \mathrm{~mm}$ across. Fruits ovoid, c. $5 \times 3 \mathrm{~mm}$, glabrous, bracts, calyx, style and stigma persistent, giving a beaked appearance.

Distribution. North Sulawesi (see Figure 35).

Habitat and ecology. Hill and upland forest at an altitude of 700-1100 m.

Etymology. This species is assumed to be named for the beaked appearance of the fruits where they are tipped by the persistent style.

Proposed IUCN conservation category. This species has an EOO of $931 \mathrm{~km}^{2}$ and an AOO of $16 \mathrm{~km}^{2}$, based on a $2 \times 2 \mathrm{~km}$ grid cell size, under the B criteria (Bachman et al., 2011). It grows at relatively low altitudes in one of the most threatened forest types (Cannon et al., 2007), in one of the most densely populated areas of Sulawesi, where there is no formal protection (UNEP-WCMC \& IUCN, 2019). Despite it occurring in one of the best-collected areas on the island, this species has been collected only six times, most recently in 1954. Because of the restricted distribution, the threat from intensive agriculture and urban expansion (Cannon et al., 2007), and the lack of any formal protection, Cyrtandra longirostris is considered to be Endangered (EN), B1ab(iii) + 2ab(iii).

Additional specimens examined. INDONESIA. North Sulawesi. Minahasa: Summit of Gunung Empung, 7 vii 1954, Alston 16280 (A, BM, BO); Tondano, 1840-1842, Forsten 157 (K, L); Ratahan, 13 iii 1895, Koorders 17182 $\beta$ (BO, L); ibid., 13 iii 1895, Koorders 17196ß (BO, L); South Minahasa: Mt Lolombulan, 6 iv 1895 , Koorders $17186 \beta(\mathrm{BO}, \mathrm{L})$.

Cyrtandra longirostris can be distinguished in Sulawesi by its combination of subequal leaves, long pedunculate inflorescences, and ovoid fruits with persistent styles. It is morphologically similar to Cyrtandra cuneata Blume from Ternate and C. calyptribracteata Bakh.f. from Java and is often misidentified as these. Because some of these names have been linked with collections from Sulawesi, we clarify their differences and nomenclatural history here.

The Sulawesi species, Cyrtandra longirostris, has small inflorescence bracts (c. $3 \mathrm{~mm}$ long), glabrous fruits and white flowers; $C$. cuneata from the Moluccas has large 
inflorescence bracts (10-15 mm long) that are not connate, hairy fruits and purplish flowers, and $C$. calyptribracteata has ovate, connate bracts $(10-15 \mathrm{~mm}$ long) that completely enclose the young inflorescence, glabrous fruits and reddish or pink flowers.

The first of these names to be published was Cyrtandra cuneata by Blume in 1826 . He did not cite any specimens but gave the distribution of the species as the Moluccas. The only specimen from the Moluccas that was collected early enough to have been seen by Blume is Reinwardt 1101 at Leiden (L2818385). In 1856, de Vriese published the names Cyrtandra longirostris and $C$. umbellata, with no reference to $C$. cuneata. Cyrtandra longirostris was described from Sulawesi, and a specimen with the details 'In monte Lujong insulae Celebes' was cited below the description. This matches a Reinwardt collection, Reinwardt 1535, at Leiden (L0277503) that also has the manuscript name Rhynchocarpus longirostris written on it, and this is selected here as the lectotype of $C$. longirostris.

Under Cyrtandra umbellata, de Vriese listed specimens from both Sulawesi and Ternate (de Vriese, 1856). The specimen from Sulawesi was a Reinwardt collection with the locality details 'Inter Lotam et Kaskassan'. It matches the specimen mounted on a sheet in the herbarium in Leiden (L0277490) and is, in fact, Cyrtandra longirostris, having small inflorescence bracts and glabrous fruits; it is listed under $C$. longirostris here. The specimen from Ternate is described as 'In sylvis montis Idjeng' and matches Reinwardt 1101 (L2818385), the type of Cyrtandra cuneata.

Clarke (1883) recognised that Cyrtandra umbellata was a synonym of $C$. cuneata. However, he incorrectly listed specimens from Sulawesi and Java under Cyrtandra cuneata. The Javanese material was later separated and described as Cyrtandra calyptribracteata (Bakhuizen van den Brink, 1950), and the Sulawesi specimen that Clarke cited under C. cuneata is moved here to $C$. longirostris.

The name Cyrtandra umbellata was also later used illegitimately by Kraenzlin for a completely unrelated Philippine species (Kraenzlin, 1913). It has subsequently been renamed Cyrtandra bacanii Olivar \& Muellner-Riehl (Olivar \& Muellner-Riehl, 2019).

21. Cyrtandra longistamina H.J.Atkins \& Karton., sp. nov.

Similar to Cyrtandra fasciata H.J.Atkins in its tessellate, scaly stem and decurrent leaves but distinguished by corolla colour (corolla creamy white or yellow with no stripes in $C$. longistamina versus corolla yellow with red stripes in $C$. fasciata), pedicel length (pedicel $15-30 \mathrm{~mm}$ long in $C$. longistamina versus pedicel $4-5 \mathrm{~mm}$ long in $C$. fasciata), calyx length (calyx $15 \mathrm{~mm}$ long in C. longistamina versus calyx $28 \mathrm{~mm}$ long in C. fasciata) and calyx texture (calyx membranaceous and not ridged in $C$. longistamina versus calyx leathery and strongly ridged in C. fasciata). - Type: Indonesia, Sulawesi, Central Sulawesi, Mt Sojol, 27 ii 2000, Mendum et al. 00197 (holotype E, isotype BO). Figure 34.

Woody herb, shrub or small tree 3-6 $\mathrm{m}$ in height. Stems tessellate, scaly, glabrous. Leaves opposite; those of a pair subequal; petioles $3-9 \mathrm{~cm}$ long, hairy towards base, particularly 


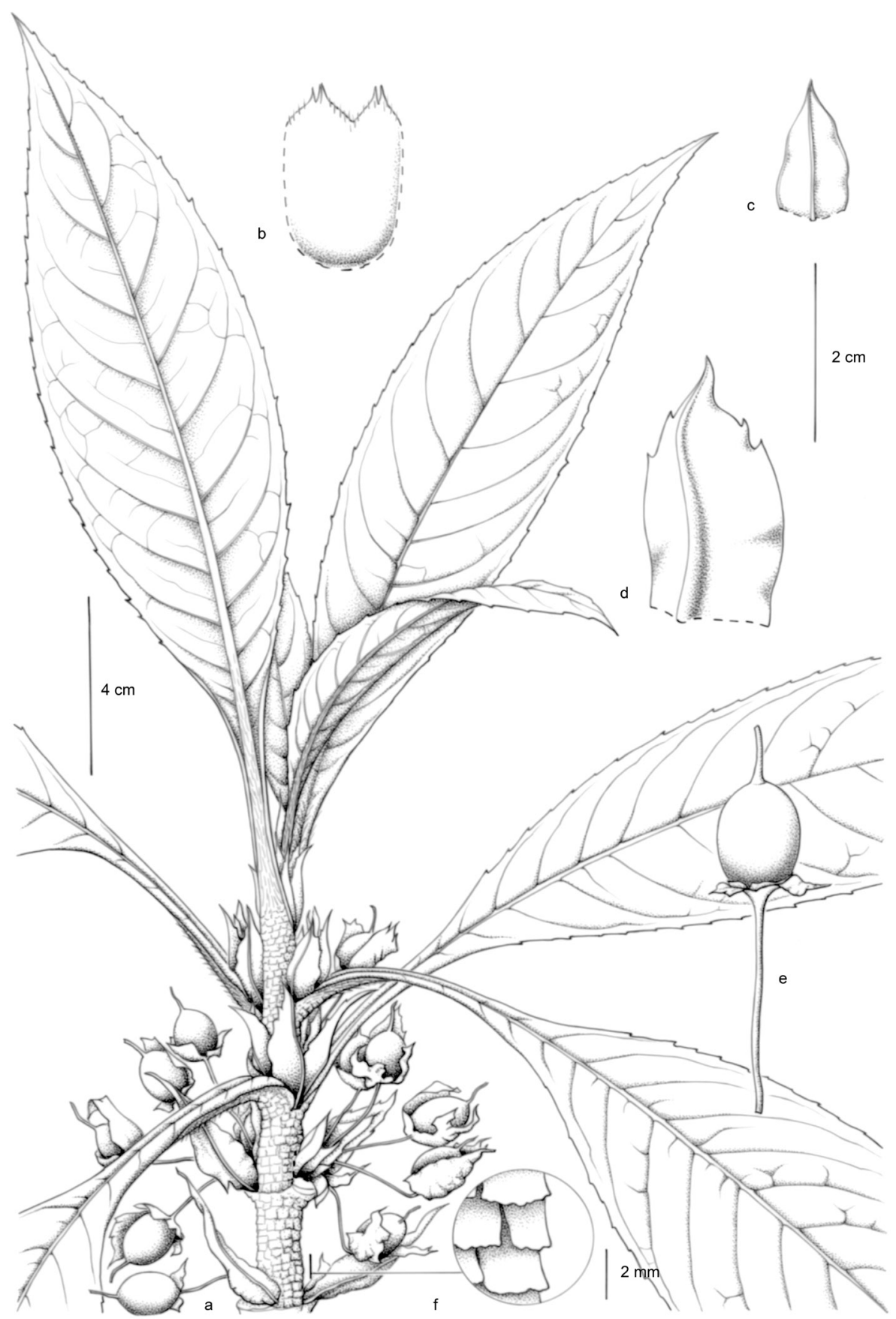

Figure 34. Cyrtandra longistamina H.J.Atkins \& Karton., sp. nov. a, Habit; b, opened calyx, showing inner surface; $c$, bracteole; $d$, bract; $e$, fruit; $f$, detail of tessellate stem surface. Drawn by Claire Banks from Mendum et al. 00197. 
on young growth; blades 10-35 ×5-11 cm, narrow oblong, base decurrent, more or less symmetrical, margins serrulate to serrate, apex short acuminate; 10-15 pairs of lateral veins and reticulate tertiary venation; subglabrous above, hairy towards base of petiole, sparsely hairy below, more densely so on midrib and veins and base of petiole. Inflorescences axillary, sessile, 2- to 6-flowered; bracts light green, c. $20 \times 10 \mathrm{~mm}$, ovate with slightly serrate margins, acuminate at apex, overlapping but not connate, glabrous; bracteoles similar to bracts but smaller and narrower; pedicels 15-30 mm long (elongating in fruit), glabrous, flushed dark reddish brown. Calyx tubular and somewhat inflated, membranaceous, pinkish or white, c. $15 \mathrm{~mm}$ long, lobes small, triangular, short-acuminate, 3-4 mm long, glabrous with a scattering of hairs on the apices of the lobes. Corolla creamy white or yellow, c. $25 \mathrm{~mm}$ long, very narrow, $3 \mathrm{~mm}$ wide at base and only widening slightly to the mouth, mouth strongly oblique, with lower lip elongated and strongly recurved, upper lobe oblong, c. $4 \times$ $4 \mathrm{~mm}$, lateral lobes also somewhat recurved, c. $4 \times 3 \mathrm{~mm}$, all lobes densely glandular hairy on inner surface, glabrous on outer surface. Stamens with filaments c. $16 \mathrm{~mm}$ long, attached c. $17 \mathrm{~mm}$ from base of corolla and extending beyond mouth of the corolla, glabrous; anthers 2-2.5 mm long, glabrous, connected at tips before dehiscence; staminodes 1-2 mm long, somewhat thickened at apex. Gynoecium c. $25 \mathrm{~mm}$ long; disc c. $1.5 \mathrm{~mm}$ long, glabrous with an undulate margin; ovary glabrous; style glandular hairy for whole length; stigma peltate to somewhat bilobed, c. $2 \mathrm{~mm}$ across. Fruits broad-ovoid, almost subglobose, glabrous, green (drying dark brown to black), 10-12 × 5-10 mm; calyx not or only partially persistent, base of style persistent.

Distribution. Central Sulawesi (Figure 35).

Habitat and ecology. Lowland, hill and upland forest at an altitude of 300-1700 m.

Etymology. This species has been named for its long filaments that exceed the corolla.

Proposed IUCN conservation category. The EOO of Cyrtandra longistamina is $10,876 \mathrm{~km}^{2}$ and the $\mathrm{AOO}$ is $24 \mathrm{~km}^{2}$, based on a $2 \times 2 \mathrm{~km}$ grid cell size, under the B criteria (Bachman et al., 2011). It has been collected from a wide altitudinal range, from $300 \mathrm{~m}$ on Mount Dako to $1700 \mathrm{~m}$ on Mount Sojol, in montane forest (Cannon et al., 2007), which is one of the least threatened forest types in Sulawesi. Because some of the collections were made within the Mount Sojol National Park and Lore Lindu National Park (UNEP-WCMC \& IUCN, 2019), a conservation assessment of Least Concern (LC) is proposed for this species.

Additional specimens examined. INDONESIA. Central Sulawesi. Donggala: Puncak Pinimoang, east of Kampung Sipatoh on the way to Mt Sojol, 1153 m, 20 vii 2002, Brown, Craven, Juswara \& Ramadhanil 83 (BO, E); Sigi: Lore Lindu National Park, 400 m N of Uwei Mbu, 17-26 vi 2011, Brambach 04-85 (CEB, E); Tolitoli: Mt Dako, Teluk Bone, Lakatan, 300 m, 24 ii 1985, Ramlanto \& Fanani 509 (BO, L); Mt Galang-Dako, 6 vii 2018, Santoso \& Rusdi WS209 (BO). 


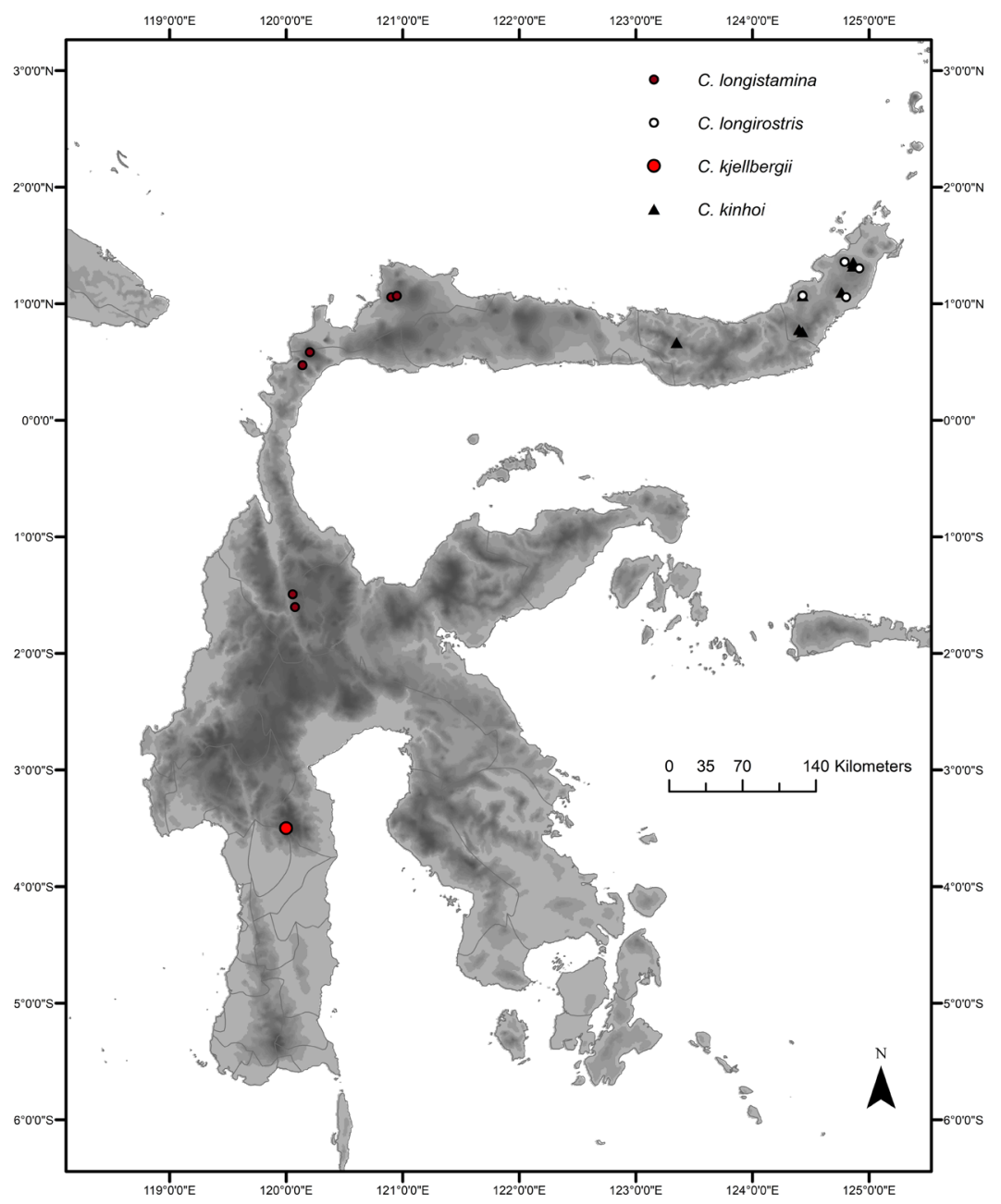

Figure 35. Distribution of Cyrtandra kjellbergii (bright red circle), C. kinhoi (black triangles), C. longirostris (white circles) and C. longistamina (dark red circles).

West Sulawesi. Mamasa: Desa Sasakan Kec. Sumarorong, 850 m, 19 ii 1986, Yusuf \& Wahyono 133 (BO).

Cyrtandra longistamina is similar vegetatively to $C$. fasciata, $C$. flavomaculata and $C$. kinhoi in having decurrent leaves and tessellate stems. It can be distinguished by its long pedicels (particularly in fruit), pale membranaceous calyx, and corolla with an elongated and recurved lower lobe with filaments and style extending beyond the mouth of the corolla. It is a variable species in terms of leaf size but all leaves have a distinctive narrow oblong shape.

Three of the collections, including the type, are from localities in proximity to Mount Sojol on the western end of the northern arm of Sulawesi, although over quite a wide altitudinal 
range, and there is a single collection from Lore Lindu National Park, collected at an altitude of $700 \mathrm{~m}$. A further collection from West Sulawesi, Yusuf \& Wahyono 133, is placed here tentatively because it has tessellate stems and the remnants of a broad-ovoid fruit. However, it is not possible to identify this collection with certainty.

22. Cyrtandra luteiflora H.J.Atkins, Edinburgh J. Bot. 60(3): 311 (2004). - Type: Indonesia, Sulawesi, Gorontalo, Mt Gambuta, 10 iv 2002, Atkins et al. 52 (holotype BO, isotype E). Figure 36.

Branching woody herb or shrub to $50 \mathrm{~cm}$ in height. Stems longitudinally striate, subglabrous, sparsely hairy when young. Leaves opposite; one of each pair markedly reduced or both well developed but somewhat unequal in size; petiole $5-8 \mathrm{~mm}$ long, sparsely hairy; blades of developed leaves $8.5-14 \times 3.5-5 \mathrm{~cm}$, narrow obovate, occasionally somewhat rhomboid, base acute, slightly asymmetrical, briefly decurrent, margin with 3 or 4 distant, rounded narrow teeth or shallow lobes on each side, apex acuminate; 4 or 5 pairs of lateral veins and some short side veins running to adjacent teeth, subglabrous above, sparsely hairy below, more densely so on midrib and veins. Reduced leaves c. $4 \times 3 \mathrm{~mm}$, either vestigial, cordate, or same shape as larger leaves. Inflorescences trailing from base of main plant or subsessile in leaf axils; trailing axis c. $1 \mathrm{~mm}$ in diameter, up to c. $1.5 \mathrm{~m}$ long, glabrous, striate, dark green; bracts c. $3 \times 1 \mathrm{~mm}$, linear, sparsely hairy, not connate; pedicel 1-2 cm long, purple, sparsely hairy. Calyx purple, c. $15 \mathrm{~mm}$ long, slightly bilabiate with a deeper sinus between the three upper and two lower lobes, lobes c.7 mm long, acuminate, glabrous to sparsely hairy, most densely so at apex of lobes. Corolla pale yellow with purple markings on lobes externally and two dark yellow to orange marks in throat, c.40 mm long, narrow funnel-shaped, arcuate, lower lobes c. $10 \times 9 \mathrm{~mm}$, upper lobes c. $8 \times 8 \mathrm{~mm}$, lobes spreading, sparsely hairy externally. Stamens with filaments $6 \mathrm{~mm}$ long, attached c. $25 \mathrm{~mm}$ above base of corolla, more or less glabrous with a scattering of short, glandular hairs near the anthers, white; anthers c. $1.5 \mathrm{~mm}$ long, cohering at apices; staminodes 3 , laterals c. $2.5 \mathrm{~mm}$ long, central c. $1.5 \mathrm{~mm}$ long. Gynoecium c. $32 \mathrm{~mm}$ long; disc cupular, margin undulate, c. $2 \mathrm{~mm}$ long, glabrous; ovary glabrous; style white, glandular hairy; stigma white, peltate, c. $2 \mathrm{~mm}$ across. Fruits narrow ovoid, dark brown, c. $15 \times 4 \mathrm{~mm}$, glabrous, calyx and base of style persistent.

Distribution. Gorontalo (see Figure 39).

Habitat and ecology. In upland forest at an altitude of $960 \mathrm{~m}$.

Etymology. This species was named for its distinctive, yellow flowers (Atkins, 2004).

Proposed IUCN conservation assessment. This species has been collected only from one locality on Mount Gambuta, and it is therefore not possible to calculate an EOO but the species has an AOO of $4 \mathrm{~km}^{2}$, based on a $2 \times 2 \mathrm{~km}$ grid cell size (Bachman et al., 2011). The collection was from an altitude of $960 \mathrm{~m}$ in upland forest, which is a habitat threatened 


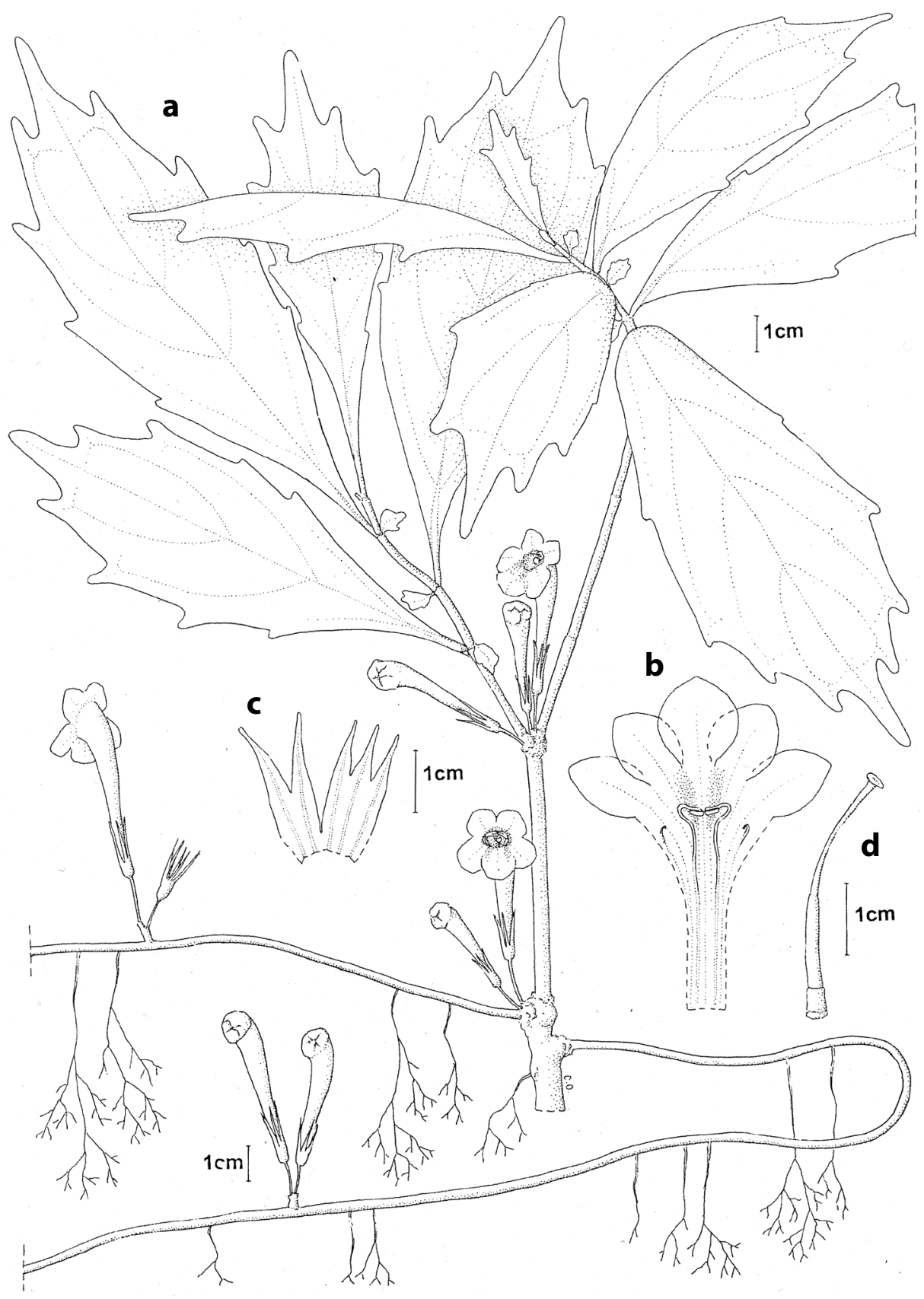

Figure 36. Cyrtandra luteiflora. a, Habit; b, opened corolla, showing position of stamens and staminodes; c, opened calyx, showing inner surface; d, gynoecium including disc. Drawn by Christina Oliver from Atkins et al. 52. Reproduced from Atkins (2004) with the permission of the Trustees of the Royal Botanic Garden Edinburgh. 
in Sulawesi from intensive agriculture and urban expansion (Cannon et al., 2007). Mount Gambuta is within the limits of the Bogani Nani Wartabone National Park (UNEP-WCMC \& IUCN, 2019) and, as such, should receive some protection. This area is one of the most under-collected on the island, and it is therefore also likely that additional populations of this species exist. Given its distribution within a protected area, a category of Least Concern (LC) is suggested for Cyrtandra luteiflora.

Additional specimen examined. INDONESIA. Gorontalo. Bone Bolango: Mt Gambuta, 10 iv 2002, Scott 02-47, grown at RBGE as accession 20021194, vouchered as Scott 504 (E).

This is one of four species from Sulawesi in which the inflorescences trail from the base of the plant, the others being Cyrtandra geocarpa, C. hypogaea and C. rantemarioensis. Cyrtandra luteiflora can be distinguished from the others by its often anisophyllous leaves, yellow flowers and glandular style.

23. Cyrtandra mollis de Vriese, PI. Ind. Bat. Orient. 16 (1856). - Rhynchocarpus mollis Reinw. ex de Vriese, PI. Ind. Bat. Orient. 16 (1856), nom. inval. - Type: Indonesia, Celebes [Sulawesi], in sylva montosa, x 1821, Reinwardt mss no. 1546 (lectotype L [L0277511], designated here; isolectotype $L$ [L02775510]).

Cyrtandra vriesii C.B.Clarke in A. \& C.DC., Monogr. Phan. 5: 237 (1883). - Type. Indonesia, Celebes [Sulawesi], Minahassa, 1 vii 1859, de Vriese \& Teijsmann 24 (lectotype L [L0277514], designated here; isolectotype L [L0277513, L0277517, L0277519]). Figure 37.

Shrub to $4 \mathrm{~m}$ in height. Stems striate, hairy, densely so on young growth. Leaves opposite; sometimes in threes, those of a group or pair well developed but somewhat unequal in size; petiole $15-20(-50) \mathrm{mm}$ long, hairy to densely hairy; blades $6-18(-30) \times 3-6(-10) \mathrm{cm}$, elliptic to narrow elliptic, sometimes lanceolate, base acute, briefly decurrent, slightly asymmetrical, margin serrulate, apex acuminate; $10-12$ pairs of lateral veins, curving upwards and running out to margin, hairy to densely hairy above and below including midrib and veins. Inflorescences axillary, sessile, 1- or 2-flowered; bracts 10-15 mm long, linear, densely hairy, soon caducous; pedicel 4-5 mm long, densely hairy. Calyx pale green, flushed reddish on lobes to deep red throughout, $12-16 \mathrm{~mm}$ long, more or less evenly divided, lobes long-acuminate, 8-10 mm long, or sometimes with lobes strongly adpressed, hairy. Corolla flushed reddish pink along tube, lobes pale yellow with pale guidemarks, appearing almost metallic, 27-38 mm long, tubular, gradually widening to mouth, slightly arcuate, lower and lateral lobes oblong, strongly recurved, c. $7 \times 6 \mathrm{~mm}$, upper lobe oblong, erect or extending forwards, $6-7 \times 4.5-5 \mathrm{~mm}$, mouth oblique, glandular hairy externally and internally on lobes and base of tube. Stamens with filaments $10-15 \mathrm{~mm}$ long, attached $14-15 \mathrm{~mm}$ from base of corolla, orange brown, glabrous, slightly glandular towards the anthers; anthers brownish, 1.5-2.5 mm long; staminodes 3 , lateral staminodes 3-6 mm long, central staminode less than $1 \mathrm{~mm}$ long. Gynoecium 20-32 mm long; disc cupular with undulate margin, c. $1 \mathrm{~mm}$ 


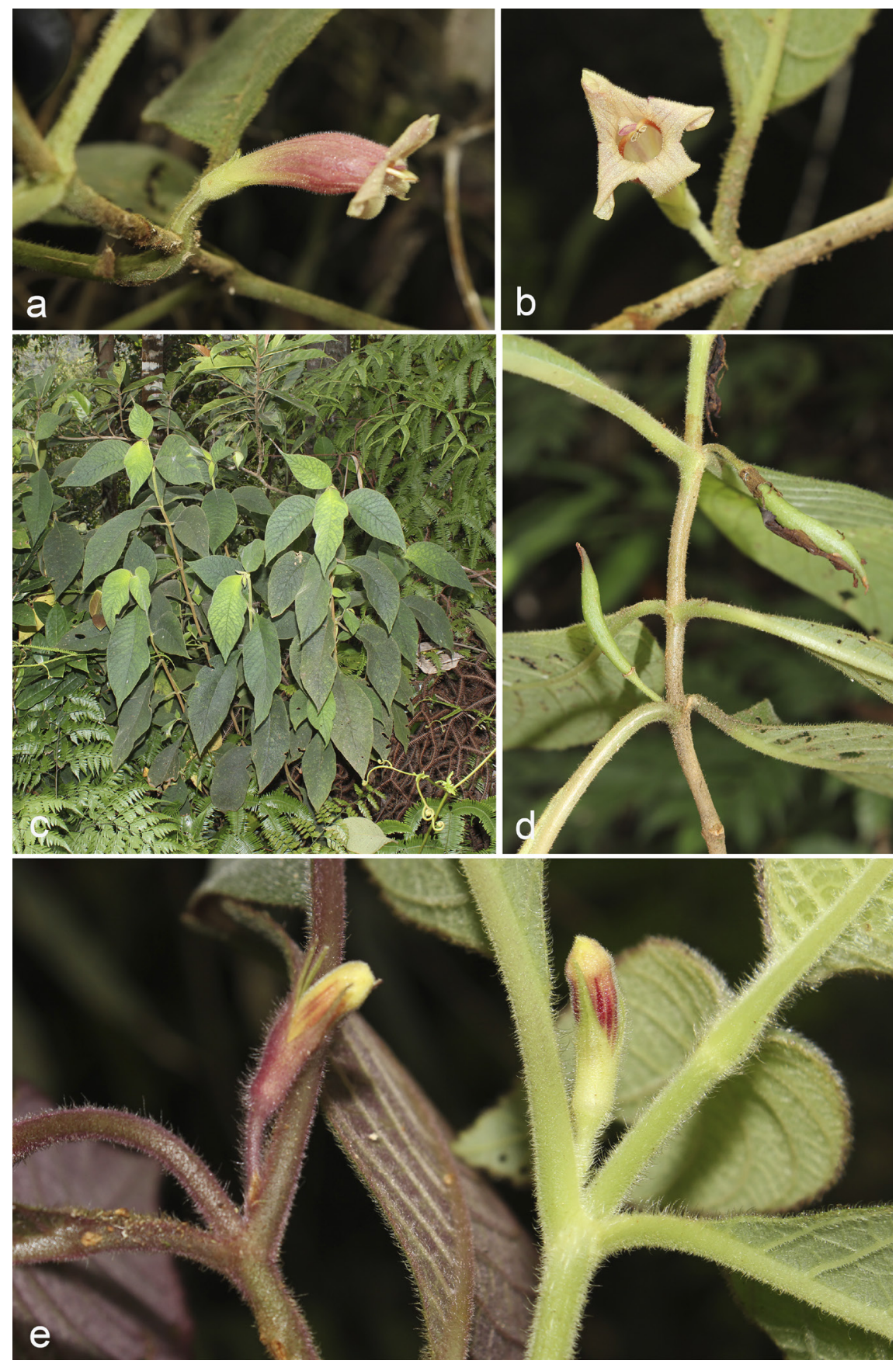

Figure 37. Cyrtandra mollis. a, Side view of flower; b, front view of flower; c, habit; d, fruits; e, samples from two plants from the same population, showing variation in colour. Photographs: Sadie Barber. Specimens: Barber et al. BAKK42 and BAKK52. 
long, glabrous; ovary subglabrous, style glandular hairy; stigma peltate, slightly bilobed, c. $2.5 \mathrm{~mm}$ across, exserted from mouth of corolla at maturity. Fruits narrow ovoid to oblong, glabrous except for glandular hairy persistent style, $20-25 \times 5 \mathrm{~mm}$, calyx and style persistent.

Distribution. North Sulawesi (see Figure 39).

Habitat and ecology. Upland forest at an altitude of 1100-1400 m.

Etymology. The epithet mollis means 'soft' or 'pliant' and possibly refers to the soft indumentum, which is velvety to the touch, or to the soft texture of the leaves.

Proposed IUCN conservation category. This species has an EOO of $1014 \mathrm{~km}^{2}$ and an AOO of $32 \mathrm{~km}^{2}$, based on a $2 \times 2 \mathrm{~km}$ grid cell size, under the B criteria (Bachman et al., 2011). Two of the collections are from within the Mount Ambang Nature Reserve, and therefore their populations should receive some protection (UNEP-WCMC \& IUCN, 2019). However, most are from the more densely populated areas around Menado and Tomohon, where there is pressure on upland forest from urban expansion and intensive agriculture (Cannon et al., 2007). Given its restricted distribution in an area of high population density and mainly lacking formal protection, Cyrtandra mollis is considered to be Vulnerable (VU), B1ab(iii) + $2 a b(i i i)$.

Additional specimens examined. INDONESIA. North Sulawesi. East Bolaang Mongondow: Mt Ambang Nature Reserve, near Singsingon village, 2 xi 2016, Barber, Atkins, Kartonegoro \& Kinho BAKK42 (BO, E); Mt Ambang accessed from Bongkudai Baru village, 3 xi 2016, Barber, Atkins, Kartonegoro \& Kinho BAKK52 (BO, E); Manado: Beclang, Unknown collector 5343 (BO, L); Menado, Unknown collector 5562 (BO); Minahasa: 7 i 1895, Koorders $17194 \beta$ (BO, L); 5 v 1895, Koorders $17181 \beta$ (BO, L); Tondano, 1923, Kruyff 17 (BO); South Minahasa: Mt Soputan, 11 x 1973, de Vogel 2498 (A, CANB, L); Tomohon: Mt Mahawu, 6 xi 2016, Barber, Atkins, Kartonegoro \& Kinho BAKK83 (BO, E); ibid., Wagio crater, 4 vii 1956, Forman 395 (BO, K, L).

Sulawesi. de Vriese s.n. (WU).

Cyrtandra mollis is the most densely hairy of the Sulawesi species, with a degree of hairiness reminiscent of that of $C$. hirtigera H.J.Atkins \& Cronk from Palawan and $C$. villosissima Merr. from Mindanao. The corolla is unusual in Sulawesi with its pale yellow and pink colouring, which appears almost metallic, and the recurved upper lobes. Collections of Cyrtandra mollis from the same population on Mount Ambang (Barber et al. BAKK42 and BAKK52) showed significant variation in the colour of the stems, leaves and calyces from light green to deep red (Figure 37E).

Cyrtandra vriesii C.B.Clarke has been reduced to synonymy here for the first time, following the herbarium annotations of B. L. Burtt. De Vriese cited a Reinwardt collection from 1821 'in sylva montosa insulae Celebes' and the manuscript name and number 'Rhynchocarpus mollis mss no 1546' when he described Cyrtandra mollis (de Vriese, 1856). 
The Leiden specimen matching these details (L0277511) is selected here as the lectotype of Cyrtandra mollis. Clarke (1883) listed de Vriese \& Teijsmann 24 in the Leiden herbarium after his description of Cyrtandra vriesii, and that specimen is selected here as the lectotype for that name.

24. Cyrtandra multinervis Karton. \& R.Bone, Edinburgh J. Bot. 75(2): 21 (2018). - Type: Indonesia, Sulawesi, Central Sulawesi, Tongoa, Mt Potong, 8 iii 2001, Kessler et al. PK 2974 (holotype BO; isotypes E, K, L). Figure 38.

Branching shrub to $4 \mathrm{~m}$ in height. Stems ridged, striate, glabrous. Leaves opposite, subequal; petioles 4-5 cm long, glabrous; blades up to $31 \times 9.5 \mathrm{~cm}$, narrow oblong or narrow elliptic, base acute, somewhat oblique, margin subentire to minutely and distantly crenulate, apex acuminate; 17-19 pairs of lateral veins and faint, reticulate tertiary venation, dark green and glabrous above, paler green and glabrous below. Inflorescences axillary, 1- to 5-flowered; peduncle 15-18 mm long, glabrous; bracts 20-23 $\times$ 9-12 mm, enclosing the flowers when in bud, ovate, glabrous; bracteoles, 9-11 $\times 3-4 \mathrm{~mm}$, ovate-elliptic, glabrous; pedicels 6-8 mm long, glabrous. Calyx tubular, pale green, 16-18 $\mathrm{mm}$ long, glabrous, lower lobes acuminate, 7-8 $\mathrm{mm}$ long, upper lobes, 3-4 mm long. Corolla white with red in the throat, 18-23 mm long, glabrous, lobes recurved, just showing above the top of the calyx, upper lobes rounded, c. $6 \times 4 \mathrm{~mm}$, lower and lateral lobes rounded, c. $4 \times 3 \mathrm{~mm}$. Stamens with filaments 5-7 mm long, attached c.9-10 $\mathrm{mm}$ above the base of the corolla, glabrous; anthers c. $2 \mathrm{~mm}$, cohering at apices. Gynoecium c. $15 \mathrm{~mm}$ long; disc cupular c. $1 \mathrm{~mm}$ long, glabrous; ovary glabrous; style glabrous at base, short hairy at apex; stigma bilobed, c. $1 \mathrm{~mm}$ across. Fruits oblong to narrowly cylindrical, sometimes curved, drying black, (10-)17-25 × 1-2 mm, glabrous, smooth; base of style persistent, calyx not persistent.

Distribution. Central Sulawesi (Figure 39).

Habitat and ecology. Upland forest at an altitude of c.980 m.

Etymology. Named for the high number of lateral veins on the leaf blades (Kartonegoro et al., 2018).

Proposed IUCN conservation category. It has not been possible to calculate EOO because there is only one collection for this species, but the AOO is $4 \mathrm{~km}^{2}$, based on a $2 \times 2 \mathrm{~km}$ grid cell size (Bachman et al., 2011). It has only been collected once from a relatively well-collected area of Sulawesi, suggesting that it is probably not locally abundant. It was collected in upland forest, which is one of the more threatened habitats in Sulawesi (Cannon et al., 2007), and although the collection locality falls within the limits of the Lore Lindu National Park, satellite imagery shows habitat degradation and conversion at that site, suggesting that the small population, if still extant, is decreasing in size. Cyrtandra multinervis is therefore assessed as Critically Endangered (CR), B2ab(iii). 


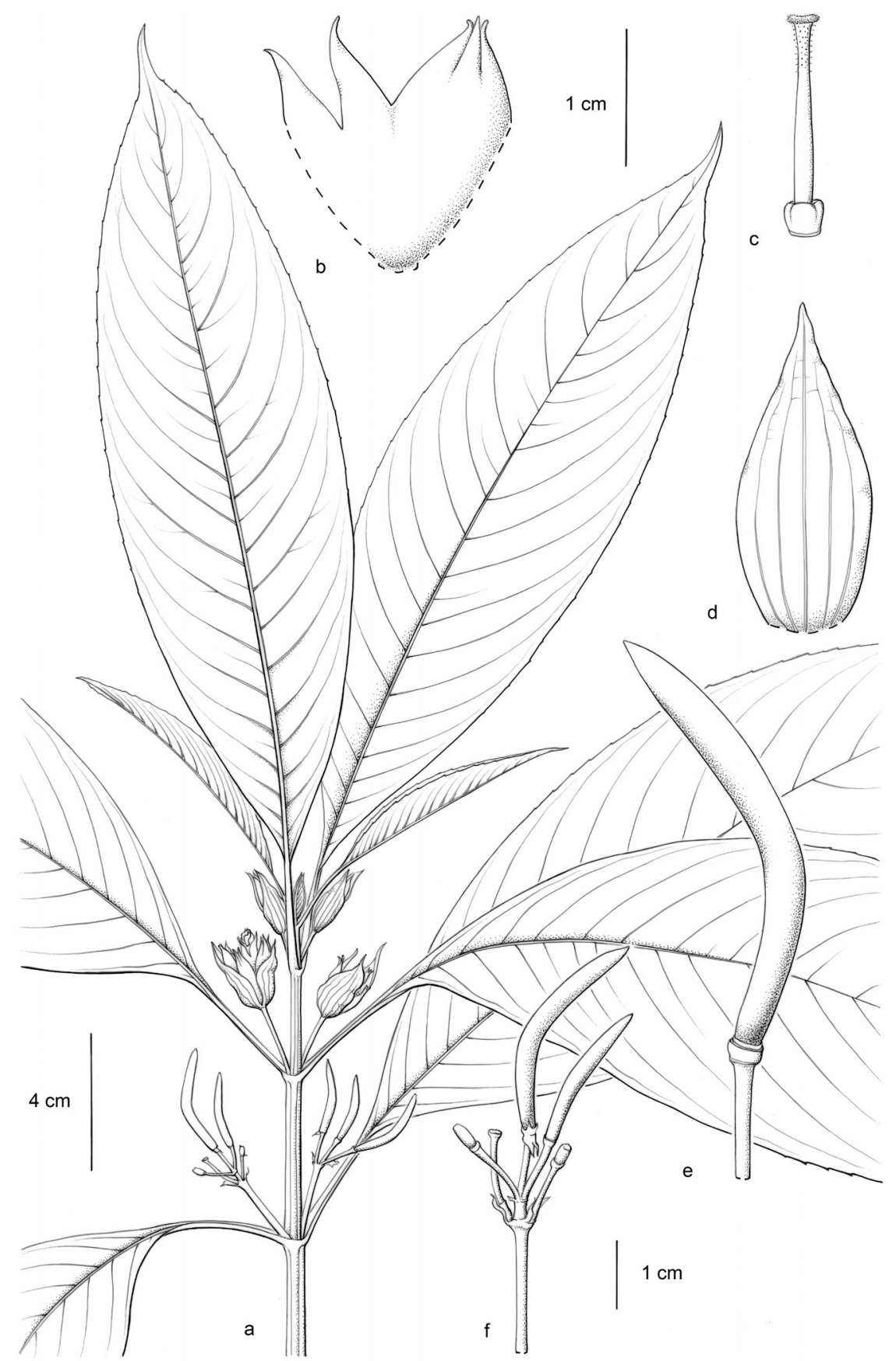

Figure 38. Cyrtandra multinervis. a, Habit; b, opened calyx, showing inner surface; c, gynoecium, showing disc; $d$ and e, fruit; f, infructescence. Drawn by Claire Banks from Kessler et al. PK 2974. Reproduced from Kartonegoro et al. (2018) with the permission of the Trustees of the Royal Botanic Garden Edinburgh. 


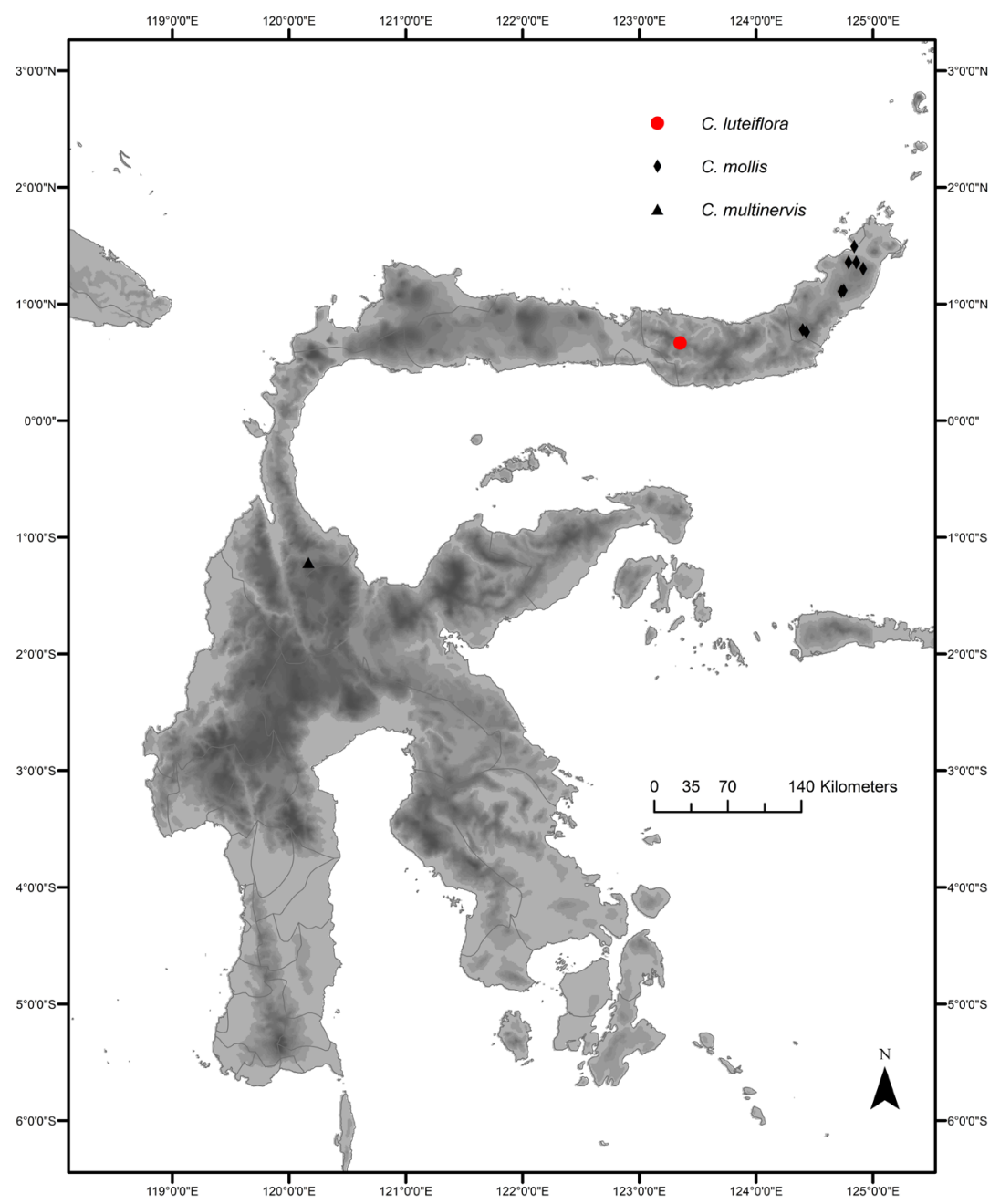

Figure 39. Distribution of Cyrtandra luteiflora (red circle), C. mollis (black diamonds) and C. multinervis (black triangle).

This species has been described from a single collection but is distinctive in Sulawesi due to its combination of narrow fruits and many-nerved leaves.

25. Cyrtandra nitida Karton. \& H.J.Atkins, Edinburgh J. Bot. 75(2): 24 (2018). - Type: Indonesia, Sulawesi, South Sulawesi, North of Mangkutana, Wotu to Lake Poso road, 20 ii 2000, Mendum, Argent \& Hendrian 00111 (holotype BO; isotypes CEB, E). Figure 40.

Herb to $2 \mathrm{~m}$ in height, sometimes branching from the base. Stems longitudinally ridged, flushed purple, sparsely woolly-hairy, more densely so on young growth. Leaves opposite, both well developed but somewhat unequal in size; blades $15.5-30.5 \times 4.5-9 \mathrm{~cm}$, oblong to 


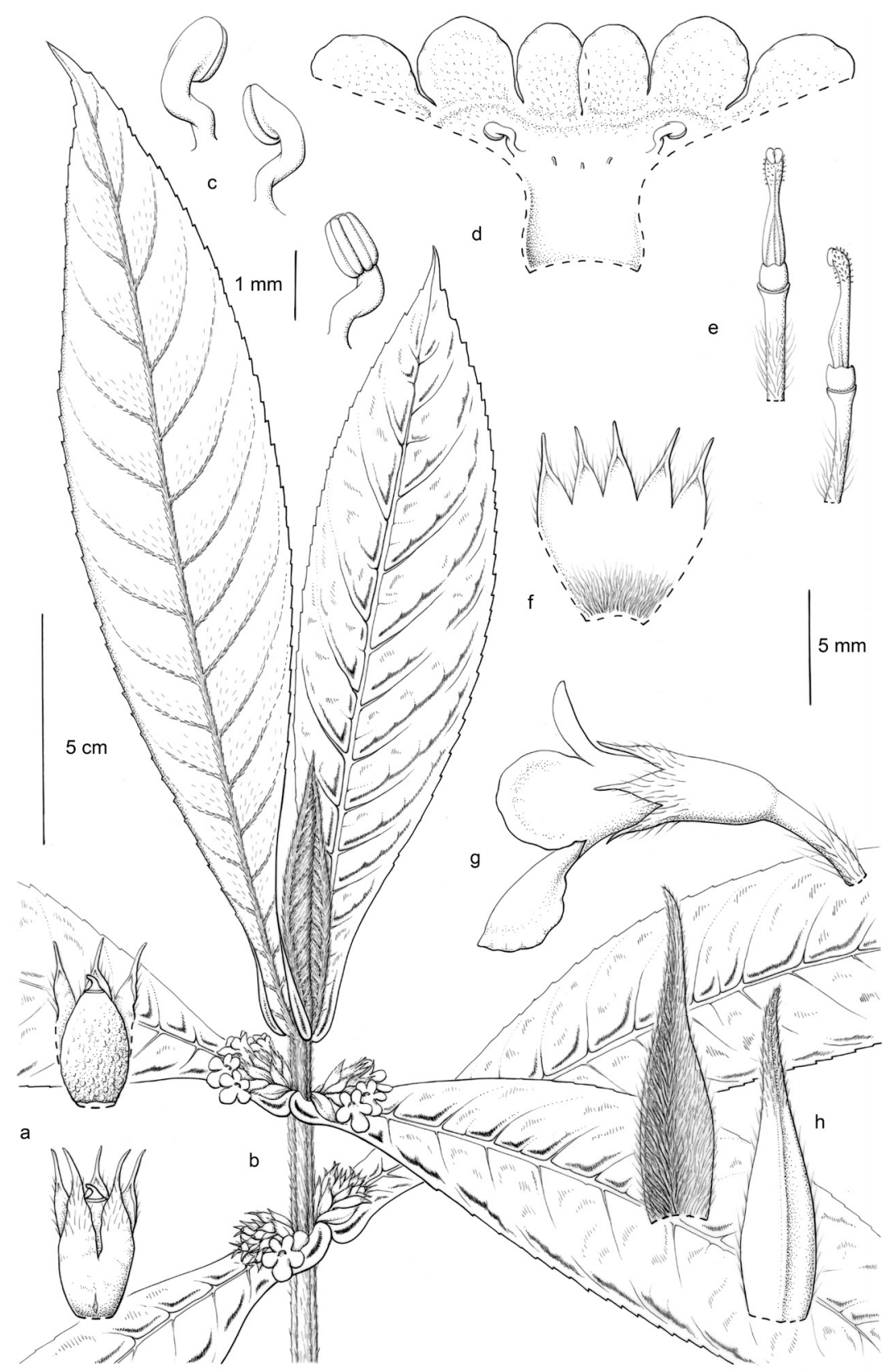

Figure 40. Cyrtandra nitida. a, Fruit with and without calyx; b, habit; c, anthers; d, opened corolla, showing position of stamens and staminodes; e, front and side views of gynoecium, including pedicel; $f$, opened calyx; g, side view of corolla; $h$, internal and external views of bracts. Drawn by Claire Banks from Sidiyasa 1369 (habit and fruit) and Mendum et al. 00111 (flowers). Reproduced from Kartonegoro et al. (2018) with the permission of the Trustees of the Royal Botanic Garden Edinburgh. 
narrow oblong, apex acuminate, base decurrent becoming auriculate, clasping the stem and touching the base of the opposite leaf, margin serrulate; 11-15 pairs of lateral veins, tertiary venation obscure; dark glossy green turning almost white at the base, more or less glabrous with some scattered hairs above; much paler below with a sparse covering of fine, golden hairs, more densely so on the midrib and veins. Inflorescences axillary, sessile, tucked in to the auriculate leaf bases, with c.10-12 flowers at various stages of development; single bract green, 15-22 × 5-8 mm, lanceolate-ovate, apex acuminate, margin slightly serrate, densely hairy above, less so below, caducous; bracteoles lanceolate, green, 15-20 $\times 4-5 \mathrm{~mm}$; pedicels light green, 3-5 mm long, hairy. Calyx green, 7-8 mm long, more or less evenly 5-lobed, lobes divided almost halfway to the base, 3-4 $\mathrm{mm}$, acuminate, sparsely hairy, more densely so on lobes. Corolla white, 8-12 mm long, tube narrow, lobes spreading, slightly projecting forwards, upper and lateral lobes orbicular, c. $5 \times 4 \mathrm{~mm}$, lower lobe slightly longer and ovate, c. $6 \times 4 \mathrm{~mm}$, subglabrous externally, with a dense covering of short, glandular hairs internally on the lobes and the mouth of the tube. Stamens with filaments 1-2 mm long, attached c. $4 \mathrm{~mm}$ from the base of the corolla, glabrous; anthers c. $1 \mathrm{~mm}$ long, glabrous; staminodes 3, c.0.5 mm long. Gynoecium 4-6 mm long; disc cupular with undulate margin, c. $1 \mathrm{~mm}$ long, glabrous; ovary glabrous at base; style glandular hairy towards apex; stigma bilobed, lobes vertical, $0.8-1 \mathrm{~mm}$ across. Fruits ovoid, dark green, brown and verrucose when dry, 4-5 $\times 2-3 \mathrm{~mm}$; most of calyx and base of style persistent.

Distribution. Central and South Sulawesi, close to the border of both provinces (see Figure 43).

Habitat and ecology. Steep, rocky roadside banks in hill and upland forest at an altitude of 500-1255 m.

Etymology. This species is named for its distinctive glossy leaves (Kartonegoro et al., 2018).

Proposed IUCN conservation category. It has not been possible to calculate the EOO for Cyrtandra nitida because the exact locality of two of the collections is not known, but it has an AOO of $8 \mathrm{~km}^{2}$, based on a $2 \times 2 \mathrm{~km}$ grid cell size, under the B criteria (Bachman et al., 2011). It has been collected in hill and upland forest between 500 and $1255 \mathrm{~m}$ in relatively disturbed areas without formal protection (UNEP-WCMC \& IUCN, 2019). We determine that the threat from habitat disturbance is continuous and assess this species as Critically Endangered (CR), B2ab(iii).

Additional specimens examined. INDONESIA. Central Sulawesi. Poso: Pegunungan Biru, Mt Mad, PosoNapu road divide, 3 viii 2018, Ardi WI291 (KRB).

South Sulawesi. East Luwu: $21 \mathrm{~km}$ south of border line between S. and C. Sulawesi, 12 xii 1994, Sidiyasa $1369(\mathrm{~K}, \mathrm{~L})$.

Cyrtandra nitida is very distinctive and unlike any others in Sulawesi due to its glossy upper leaf surface and the auriculate leaf bases that clasp the stem and hold the inflorescence. 
26. Cyrtandra parvicalyx H.J.Atkins \& Karton., sp. nov.

Similar to Cyrtandra widjajae Karton. in having markedly anisophyllous leaves, white, hairy flowers and hairy fruits, but distinguished by its shorter calyx (calyx $3-5 \mathrm{~mm}$ long, $1 / 4$ to $1 / 3$ the length of the corolla in C. parvicalyx versus calyx $6-10 \mathrm{~mm}$ long, $1 / 2$ to $3 / 4$ the length of the corolla in $C$. widjajae); smaller leaves with fewer lateral veins (leaves $6-9 \times 1.5-2.5 \mathrm{~cm}$ with 4 or 5 pairs of lateral veins in $C$. parvicalyx versus leaves 7-16 $\times 2-4 \mathrm{~cm}$ with 8-14 pairs of lateral veins in $C$. widjajae) and longer pedicels (4-7 $\mathrm{mm}$ long in $C$. parvicalyx versus $2-4 \mathrm{~mm}$ long in $C$. widjajae). - Type: Indonesia, Central Sulawesi, Mt Sojol, 26 ii 2000, Mendum et al. 00158 (holotype BO, isotype E). Figure 41.

Shrub to $1 \mathrm{~m}$ in height. Stems striate, subglabrous, hairy on young growth. Leaves usually appearing alternate, sometimes opposite with one leaf of a pair markedly reduced; petioles 8-10 mm long, glabrous to sparsely hairy; blades $6-9 \times 1.5-2.5 \mathrm{~cm}$, oblanceolate to narrow oblanceolate, base acute, slightly asymmetrical, margin subentire to serrulate, apex long-acuminate; 4 or 5 pairs of lateral veins, curving upwards and eventually out to margin; subglabrous above, sparsely hairy below more densely so on midrib and veins. Reduced leaves (where present) cordate, $2 \times 1 \mathrm{~mm}$. Inflorescences axillary, sessile, 1- or 2(-3)-flowered; bracts linear, 2-3 $\times 1 \mathrm{~mm}$, hairy, caducous; pedicels 4-7 mm long, hairy. Calyx cupular, evenly 5-lobed, white, $3-5 \mathrm{~mm}$ long, $1 / 4$ to $1 / 3$ corolla length, lobes narrow, acuminate at apex, 2-3 mm long, hairy externally. Corolla white, 12-16 mm long, narrow funnel-shaped, narrow in basal half then gradually widening to mouth, lobes spreading, upper lobes rounded, somewhat acute at apex, 3-4 $\times 2-2.5 \mathrm{~mm}$, lower and lateral lobes oblong, acute at apex 3-4 × 2-3 mm, long white-hairy externally. Stamens with filaments 4-5 mm long, attached 7-8 $\mathrm{mm}$ from the base of corolla, glabrous; anthers $0.8-1 \mathrm{~mm}$ long, connected at tips before dehiscence; staminodes 3 , lateral staminodes c. $0.5 \mathrm{~mm}$ long, central staminode slightly shorter. Gynoecium 10-14 mm long; disc cupular with deeply lobed margin, 1-1.5 mm long, glabrous externally but with a fringe of hairs along margin; ovary and style densely eglandular hairy; stigma bilobed, 1-1.2 mm across. Fruits narrow ovoid, c. $10 \times 3 \mathrm{~mm}$ (excluding style), densely hairy; style persistent, calyx not persistent.

Distribution. Central Sulawesi: Mount Sojol (see Figure 43).

Habitat and ecology. Upland forest at an altitude of c.1400 m.

Etymology. This species is named for its short calyx relative to the length of the corolla.

Proposed IUCN conservation category. Cyrtandra parvicalyx is known only from the type location so it has not been possible to calculate the EOO, but it has an AOO of $4 \mathrm{~km}^{2}$, based on a $2 \times 2 \mathrm{~km}$ grid cell size, under the B criteria (Bachman et al., 2011). It was collected in the Mount Sojol Nature Reserve (UNEP-WCMC \& IUCN, 2019), from an altitude of c.1400 m, close to the edge of montane forest sensu Cannon et al. (2007), which is one of the less 


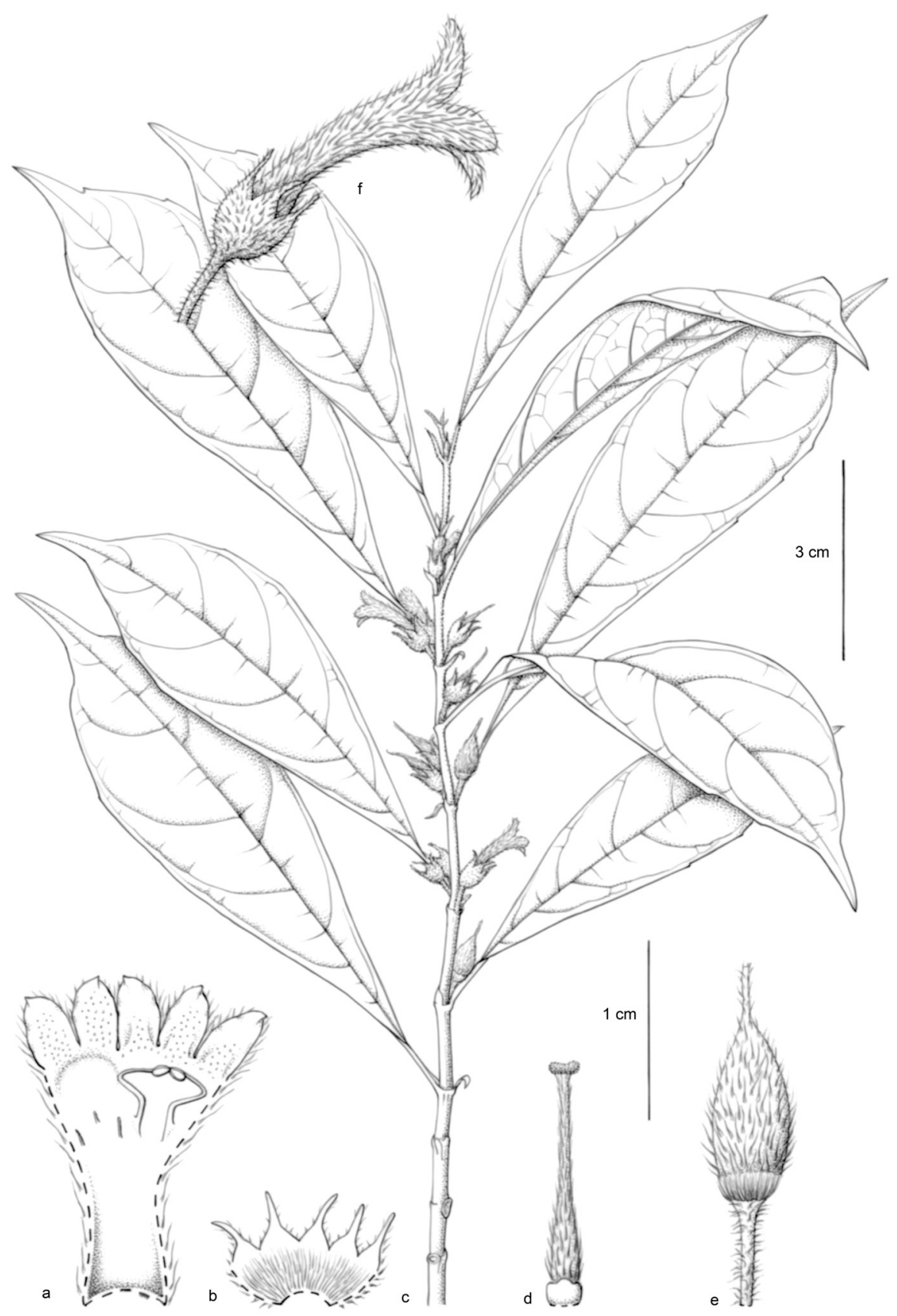

Figure 41. Cyrtandra parvicalyx H.J.Atkins \& Karton., sp. nov. a, Opened corolla, showing position of stamens and staminodes; b, opened calyx; $c$, habit; $d$, gynoecium including disc; $e$, fruit; $f$, side view of flower. Drawn by Claire Banks from Mendum et al. 00158 (habit and fruit from dried material, and floral details from spirit material). 
threatened forest types in Sulawesi (70\% of upland forests above $1500 \mathrm{~m}$ elevation are intact). Despite the very restricted distribution of this species, a category of Least Concern (LC) is suggested due to its location in a protected area and in a relatively unthreatened habitat.

Cyrtandra parvicalyx is known only from the type collection. It is part of a group on the island that share the characteristics of markedly anisophyllous leaves; white, hairy flowers; and hairy fruits. It can be most easily distinguished from the others in the group by a combination of its short calyx relative to the length of the corolla, its cordate reduced leaves, and its very narrow, tubular corolla widening only near the mouth.

27. Cyrtandra polyneura (C.B.Clarke) B.L.Burtt, Edinburgh J.Bot. 47(3): 225 (1990). Cyrtandra decurrens de Vriese var. polyneura C.B.Clarke in A. \& C.DC., Monogr. Phan. 5: 233 (1883). - Type: Celebes [Sulawesi], Minahassa, Tondano, iv 1840, Forsten 86, sheet no. 903.307-520 (lectotype L). Figure 42.

Herb or shrub to $1 \mathrm{~m}$ in height. Stems striate, sparsely hairy, more densely so on young growth. Leaves opposite; those of a pair subequal or well developed but somewhat unequal in size; blades 15-35 × 5-10 cm, oblanceolate, base decurrent, laminas of opposite leaves connate at base when young, margin serrate, apex short-acuminate; 7-15 pairs of lateral veins, curving upwards and running out to margin, glabrous above, often warty at base, sparsely hairy below, more densely so on midrib and veins. Inflorescences axillary, subsessile or pedunculate, many-flowered; bracts wide ovate, up to $25 \times 20 \mathrm{~mm}$, subglabrous, warty at base, partially united, forming an involucre containing 8-16(-20) small flowers at various stages of development; peduncles up to $25 \mathrm{~mm}$ long, hairy; pedicels 1-3 mm long, glabrous to sparsely hairy, sometimes warty. Calyx tubular, greenish brown, 8-9 mm long, sparsely hairy, 5-lobed, lobes acuminate at apex, 2-3 mm long. Corolla white to pale yellow with yellow or pale orange patches on lobes and throat and red spots in throat, $10-15 \mathrm{~mm}$ long, tube narrow in basal $1 / 3$, gradually widening to mouth in apical $2 / 3$, lobes not recurved, upper lobes $2-3 \times 3 \mathrm{~mm}$, lower lobes $3 \times 4 \mathrm{~mm}$, hairy externally, and with a scattering of glands below the lobes internally. Stamens with filaments $3-5 \mathrm{~mm}$ long, attached c. $5 \mathrm{~mm}$ from base of corolla, glabrous but with some sessile glands; anthers 1-1.5 mm long, face to face and connected at apices before dehiscence; staminodes 3 , laterals c. $4 \mathrm{~mm}$ long, central c. $1.5 \mathrm{~mm}$ long. Gynoecium c. $10 \mathrm{~mm}$ long; disc 1-1.5 mm long, cupular with lobed margin, glabrous; ovary subglabrous to sparsely eglandular hairy; style eglandular hairy for whole length; stigma peltate, slightly bilobed, 1.5-2 mm across. Fruits narrow ovoid to oblong, green or turning purplish, up to $10 \times 5 \mathrm{~mm}$, subglabrous; calyx and bracts not persistent.

Distribution. North Sulawesi, Gorontalo, Central Sulawesi, West Sulawesi, South Sulawesi, Southeast Sulawesi (Figure 43). 


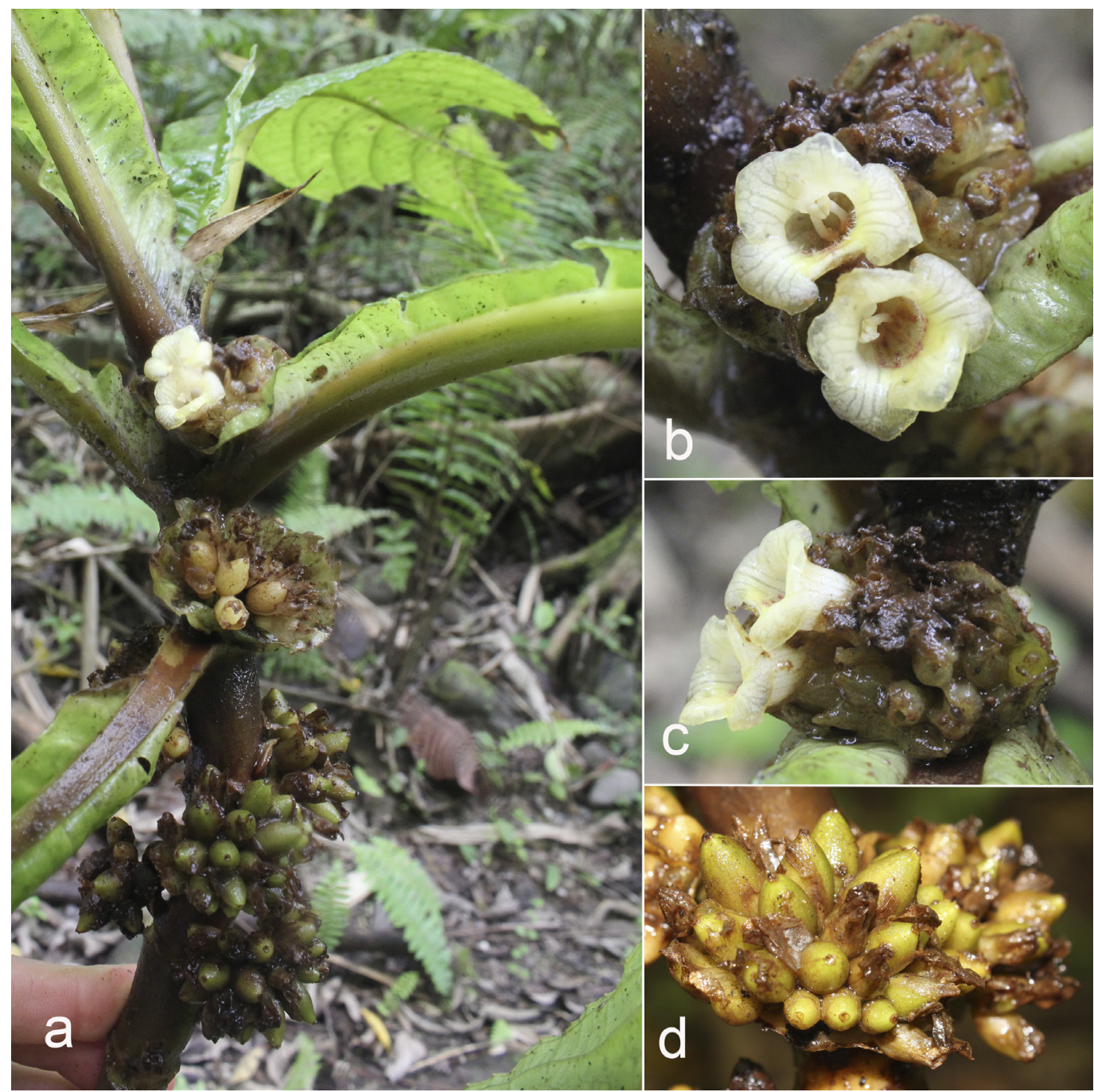

Figure 42. Cyrtandra polyneura. a, Habit and stem, showing inflorescences and infrutescence at various stages; $b$, front view of corolla and bracts forming an involucre; $c$, side view of flower and young buds; d, fruits. Photographs: Sadie Barber. Specimen: Barber et al. BAKK18.

Habitat and ecology. Disturbed lowland, hill and upland forest at an altitude of 200-1200 m.

Etymology. This species is named for the high number of secondary veins (Clarke, 1883).

Proposed IUCN conservation category. Cyrtandra polyneura is one of the most common and widespread species on the island and, unusually for Cyrtandra, is often found growing in large patches. Its EOO is $294,062 \mathrm{~km}^{2}$ and its AOO is $132 \mathrm{~km}^{2}$, based on a $2 \times 2 \mathrm{~km}$ grid cell 


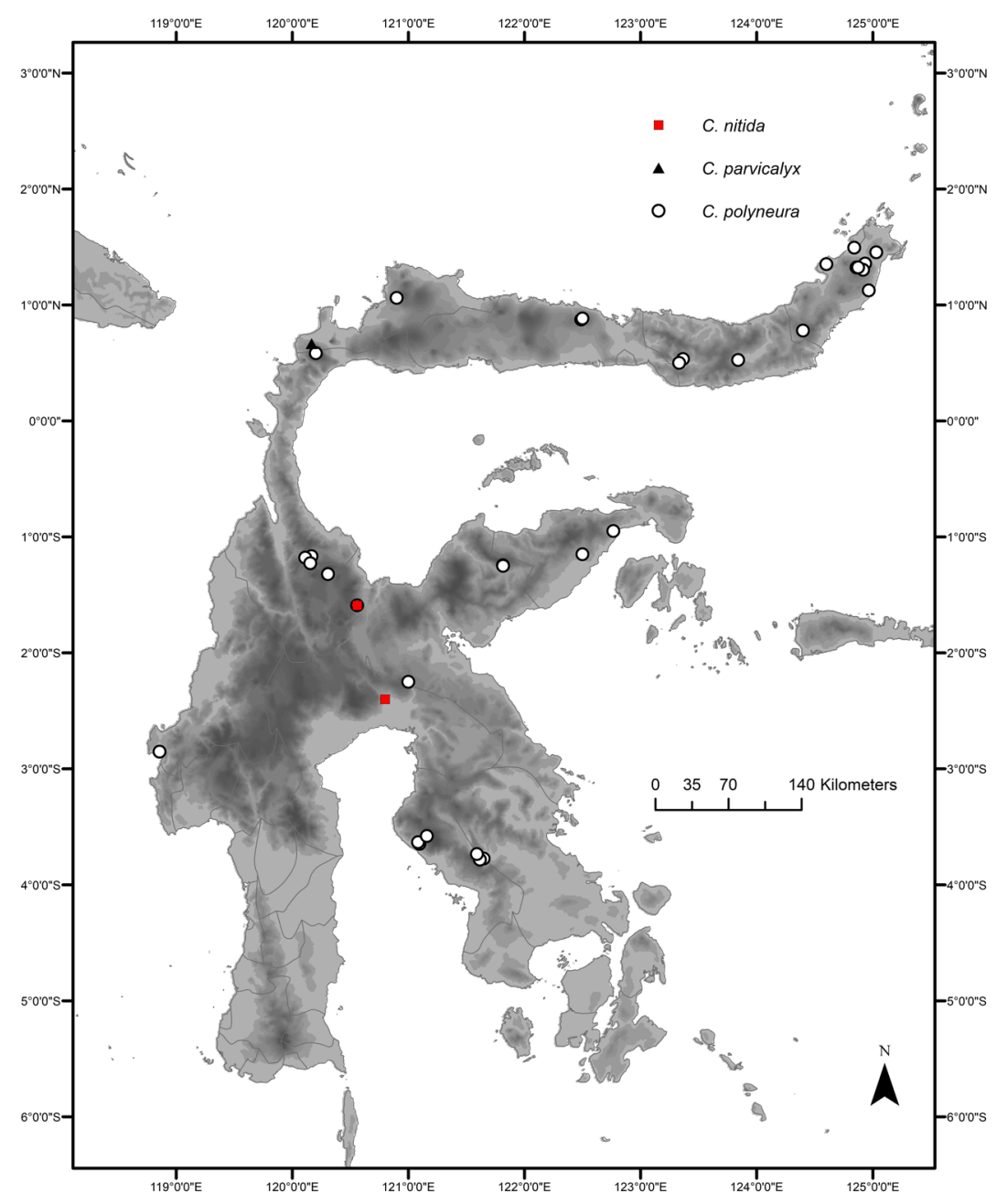

Figure 43. Distribution of Cyrtandra nitida (red squares), C. parvicalyx (black triangle) and C. polyneura (white circles).

size, under the B criteria (Bachman et al., 2011). We propose a category of Least Concern (LC) for this species.

Additional specimens examined. INDONESIA. North Sulawesi. Bolaang Mongondow: Kasingolan River, 30 x 2016, Barber, Atkins, Kartonegoro \& Kinho BAKK18 (BO, E); East Bolaang Mongondow: Mt Ambang Nature Reserve, 2 xi 2016, Barber, Atkins, Kartonegoro \& Kinho BAKK41 (BO, E); Manado: 4 iii 1895, Koorders 17109 $\beta$ (BO); Minahasa: West slope of Mt Masarang, 20 vi 1954, Alston 15952 (A, BM, BO); Tanggari, 5 vii 1954, Alston 16223 (BM); Mt Manembo-nembo, 28 vii 1954, Alston 16576 (A, BM, BO); Mt Masarang, 2 ii 2019, Ardi WI398 (KRB); ibid., 10 i 1895, Koorders 17185ß (BO); Kayuwatu, 23 ii 1895, Koorders $17195 \beta$ (BO, L); Minahasa, 4 iii 1895, Koorders $17189 \beta$ (BO, L); North Minahasa: Mt Klabat, 19 i 
1895, Koorders $17200 \beta$ (BO); Talaud Islands: Sangihe Talaud, s slope of Mt Duata, 30 iv 1926, Lam 2697 (S).

Gorontalo. Bone Bolango: route along the Olama river to Mt Gambuta, 9 iv 2002, Atkins et al. 40 (BO, E); Between Pinogu and Tulabolu, 15 iv 2002, Atkins et al. 114 (BO, E); Gorontalo: Path from Bululi to Mt Boliohutu, 22 iv 2002, Atkins et al. 142 (BO, E); Mt Boliohutu, 22 iv 2002, Scott 02-106, grown on at RBGE as accession 20141650, vouchered as Atkins 58 (E).

Central Sulawesi. Banggai: inland from Batui, 14 x 1989, Coode 5933 (BO, K, L); Mt Lumut, 7 ix 1938 , Eyma 3697 (BO); Hanga-Hanga waterfall, 8 iv 2008, Thomas \& Ardi 08-25 (BO, E); steep river bank, 24 iv 2008, Thomas \& Ardi 08-63 (BO); steep river bank, 24 iv 2008, Thomas \& Ardi 08-64 (BO, E); between rocks on riverside, 24 iv 2008, Thomas \& Ardi 08-65 (BO, E); Donggala: Mt Sojol, 29 ii 2000, Mendum et al. 00217 (E); Sigi: Lore Lindu National Park, Mt Nokilalaki, 24 ii 2018, Ardi WI220 (KRB); ibid., Mt Mad, 3 viii 2018, Ardi WI288 (KRB); ibid., Tamping Lake area, 4 viii 2018, Ardi WI300 (KRB); ibid., Sopu Valley, c. 80 km SSE of Palu, 26 iv 1979, van Balgooy 3005 (A, E, L); East of Tongoa, 2 iii 1981, Johansson, Nybom et al. 135 (E, L); Toli-Toli: Mt Galang-Dako, 8 vii 2018, Santoso \& Rusdi WS256 (BO).

West Sulawesi. Mamuju: Tapalang, 4 viii 1912, Noerkas 433 (BO, L).

South Sulawesi. East Luwu: Soroako-Wasuponda Road, 7 vii 1979, van Balgooy 3911 (A, BO, E, L).

Southeast Sulawesi. Kolaka: Mt Watuwila, Pondunaah, 13 v 2008, Girmansyah 883 (BO); ibid., village of Sanggona, 15 v 2008, Kartonegoro ARK239 (BO); ibid., 17 v 2008, Wiriadinata HW13371 (BO); North Kolaka: Mt Mekongga, Tinukari Village, 29 vi 2010, Widjaja \& Sujadi EAW9051 (BO, E); ibid., 30 vi 2010, Widjaja, Sujadi, Santoso \& Hapid EAW9699 (BO); ibid., 30 vi 2010, Widjaja, Sujadi, Santoso \& Hapid EAW9712 (BO).

Cyrtandra polyneura is one of the most widespread and common species in Sulawesi, and is distinguished by its involucrate, many-flowered axillary inflorescences and decurrent leaves. It was originally described as a variety of the Moluccan species Cyrtandra decurrens de Vriese by C. B. Clarke (1883). It was subsequently raised to species level by Burtt (1990), the Sulawesi species being distinguished by having much longer leaves; warty, partially united inflorescence bracts; and sparsely hairy calyx lobes (Burtt, 1990).

A number of the specimen labels record that the plant is collected and eaten as a vegetable. The leaves of this species have been seen on sale in a public market in Mamasa, West Sulawesi (A. Kartonegoro, personal observation).

28. Cyrtandra purpurea H.J.Atkins, Edinburgh J. Bot. 60(3): 313 (2004). - Type: Indonesia, Sulawesi, Central Sulawesi, Upper Sopu River, 25 v 1979, van Balgooy 3503 (holotype L; isotypes A, BO, E). Figure 44.

Branching, climber or epiphytic shrub (height not recorded). Stems striate, subglabrous. Leaves opposite, subequal; petiole 10-20 mm long, glabrous; blades $17-22 \times 4-5 \mathrm{~cm}$, narrow oblong, base acute, margin entire, apex acuminate; 11-14 pairs of lateral veins, not reaching margin, tertiary venation faint on herbarium specimens, glabrous above, sparsely hairy on midrib and veins below. Inflorescences axillary, sessile, 1- or 2-flowered, from near apex to base of stem; bracts not seen (soon caducous?); pedicels up to $15 \mathrm{~mm}$ long, extending in fruit, glabrous. Calyx tubular, purple, coriaceous, 10-11 mm long, 5-lobed, 


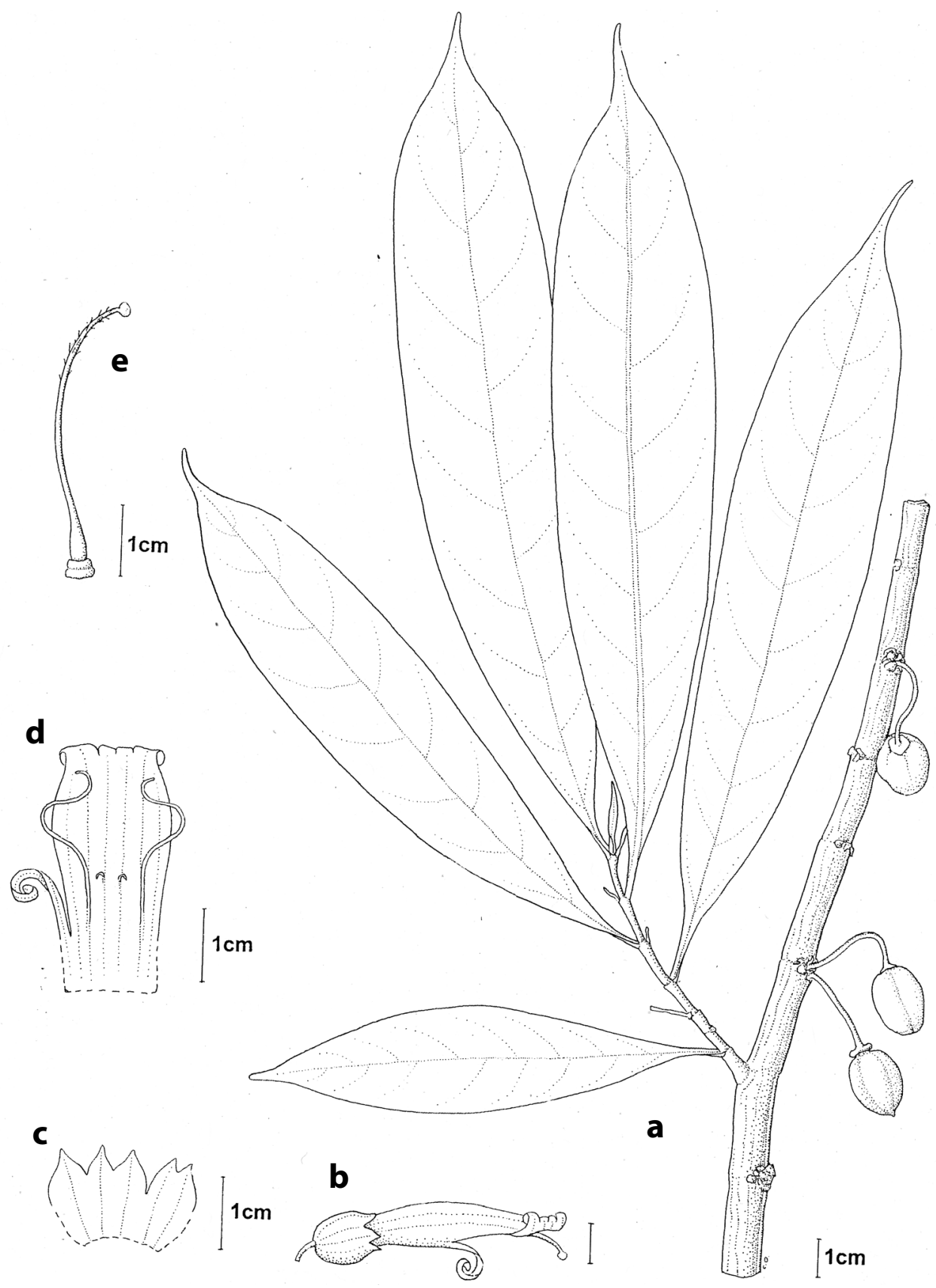

Figure 44. Cyrtandra purpurea. a, Habit; b, side view of corolla; c, opened calyx, showing inner surface; $\mathrm{d}$, opened corolla, showing position of stamens and staminodes; e, gynoecium including disc. Drawn by Christina Oliver from van Balgooy 3503. Reproduced from Atkins (2004) with the permission of the Trustees of the Royal Botanic Garden Edinburgh. 
slightly bilabiate, lobes triangular, $5 \mathrm{~mm}$ long, glabrous. Corolla purple to brown, c.30 mm long, tubular, glabrous externally, mouth oblique, limb strongly bilabiate, lower median lobe linear and strongly recurved, c. $8 \times 1.5 \mathrm{~mm}$, upper and lateral lobes recurved, 2-3 mm long. Stamens with filaments c. $20 \mathrm{~mm}$ long, attached c. $10 \mathrm{~mm}$ from base of corolla; anthers not seen (damaged on all specimens); staminodes 3 , lateral staminodes c. $1 \mathrm{~mm}$ long, central staminode minute, barely visible. Gynoecium c. $35 \mathrm{~mm}$ long; disc cupular, margin subentire to undulate, c. $1 \mathrm{~mm}$ long, glabrous; ovary glabrous; style glandular hairy for much of its length; stigma peltate, c. $2 \mathrm{~mm}$ across, exserted. Fruits subglobose, fleshy, 10-17 × 10-12 mm, green when unripe, glabrous, calyx not persistent, base of style persistent.

Distribution. Central Sulawesi (see Figure 47).

Habitat and ecology. Upland forest at an altitude of 940-1000 m.

Etymology. This species is named for the unusual purple colour of its corolla (Atkins, 2004).

Proposed IUCN conservation category. The low number of collection localities gives an AOO of $8 \mathrm{~km}^{2}$, based on a $2 \times 2 \mathrm{~km}$ grid cell size (Bachman et al., 2011). This species has been collected on only two occasions despite this being one of the better-collected areas of Sulawesi, suggesting that the small AOO is fairly accurate. All the collections were made between 940 and $1000 \mathrm{~m}$ in upland forest, which is one of the more threatened forest types on the island (Cannon et al., 2007), and although the collection localities are within the Lore Lindu National Park, satellite imagery show signs of habitat degradation and land conversion in at least one of these sites, suggesting a negative population trend. Cyrtandra purpurea is therefore assessed as Endangered (EN) B2ab(iii).

Additional specimens examined. INDONESIA. Central Sulawesi. Sigi: Sopu Valley, 1000 m, 3 v 1979, van Balgooy 3124 (A, BO, E, L); Kec Palolo, Kamarora, Mt Potong, 940 m, 17 xi 2000, Kessler PK2892 (K, L); Sopu Valley, 1000 m, 6 v 1979, de Vogel 5231 (BO, K, L).

Cyrtandra purpurea is very distinctive due to its climbing or epiphytic habit, subglobose fruit, purple flowers with characteristic elongated lower lobe, and leathery oblong leaves with obscure tertiary venation. There is a collection from Mount Potong whose label states that there are four seeds in the fruit, which would not be correct for Cyrtandra. It has not been possible to dissect the fruit to confirm this, but we have assumed that the label information is incorrect, being possibly based on the observation of the four intrusive arms of the placentae in an immature fruit.

29. Cyrtandra purpureofucata R.Bone \& H.J.Atkins, Edinburgh J. Bot. 70(3): 461 (2013). Type: Indonesia, Sulawesi, South Sulawesi, Mt Rantemario, 26 iv 2009, Thomas \& Ardi 09-88 (holotype E; isotypes BO, L). Figures 45, 46.

Herb or shrub 1-4 m in height. Stems woody, terete, warty, hairy, densely so when young. Leaves subequal to markedly anisophyllous or appearing alternate; petiole 6-10 mm long, 


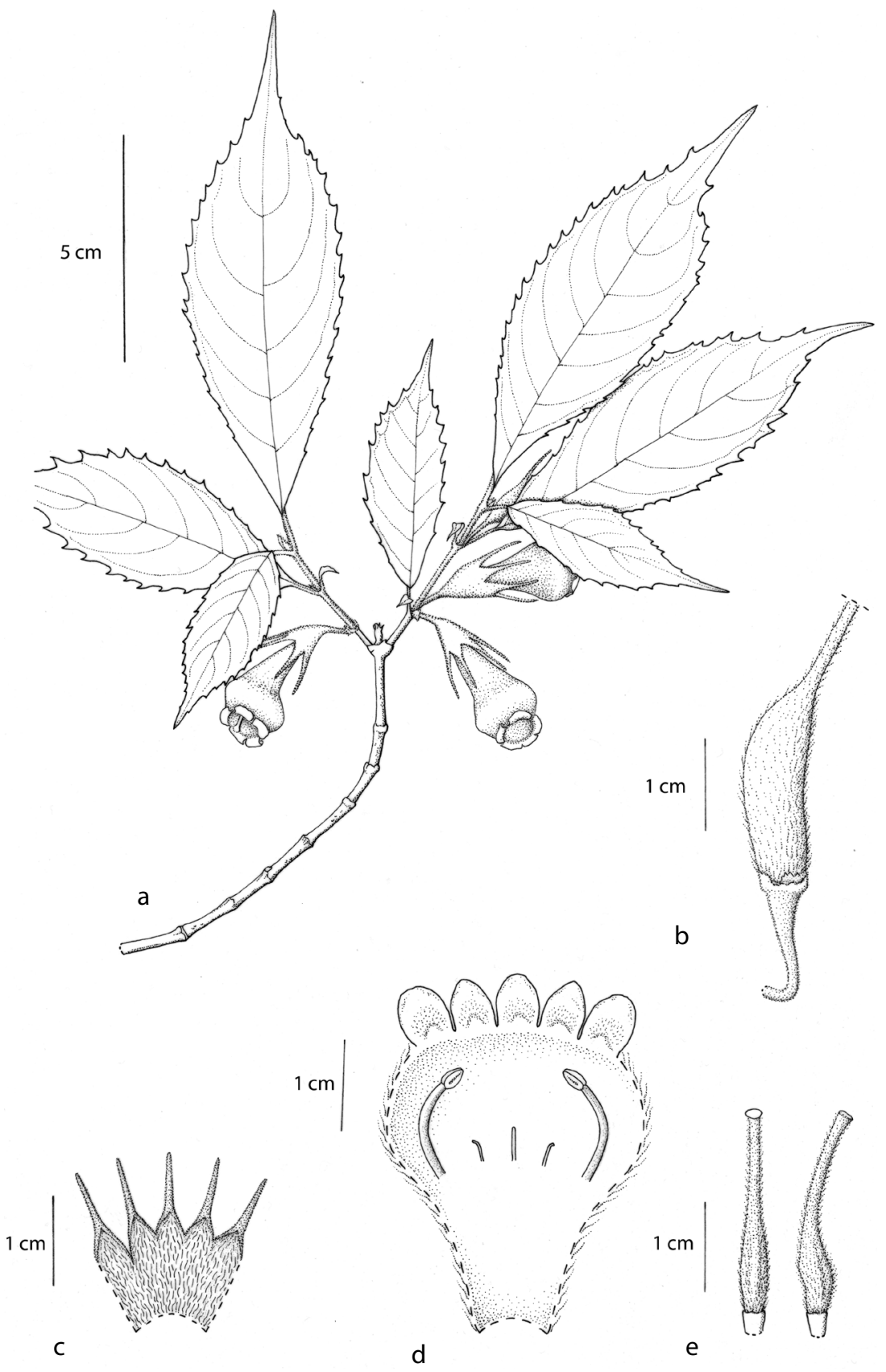

Figure 45. Cyrtandra purpureofucata. a, Habit; b, fruit; c, opened calyx, showing inner surface; $d$, opened corolla, showing position of stamens and staminodes; e, gynoecium and disc. Drawn by Claire Banks from Thomas \& Ardi 09-88. Reproduced from Bone \& Atkins (2013) with the permission of the Trustees of the Royal Botanic Garden Edinburgh. 


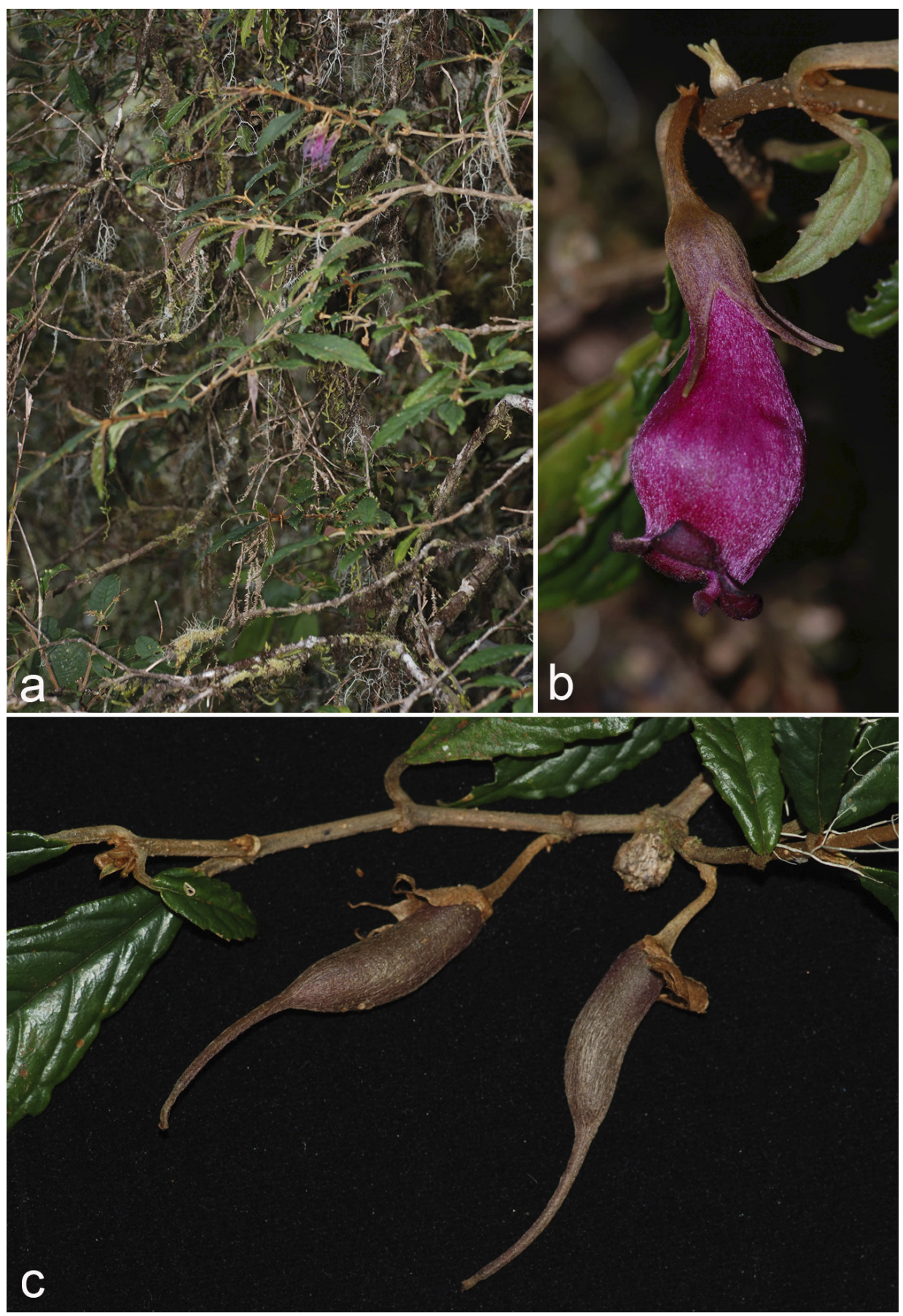

Figure 46. Cyrtandra purpureofucata. a, Habit; b, side view of corolla; c, fruits. Photographs: Wisnu Ardi. Specimen: Thomas \& Ardi 09-88. 
hairy; blades of larger leaves $4.5-10 \times 1.5-3 \mathrm{~cm}$, narrow elliptic to somewhat oblanceolate, base acute, margin serrate, apex acuminate; 5-8 pairs of lateral veins, very prominent below on dried specimens, upper surface glabrous, lower surface with appressed hairs on primary and secondary veins, glabrescent between veins, juvenile leaves more densely hairy. Reduced leaves (where present) 1-2 ×0.5-1 cm, elliptic. Inflorescences axillary, sessile, 1- or 2-flowered; bracts 2-5 mm long, sometimes caducous, linear, hairy; pedicels 5-19 mm long, densely hairy. Calyx green, coriaceous, 11-15 mm long, more or less evenly 5-lobed but with the division on the lower side slightly deeper; lobes 4-10 mm long, apex narrow caudate to linear, hairy externally. Corolla deep pink externally, pale pink internally with dark purple lobes, 25-37 mm long; tube narrow in basal half becoming wider and pouched in apical half, narrowing again at mouth; lobes strongly recurved, the lower and lateral lobes being slightly larger than the upper two, c. $4 \times 4 \mathrm{~mm}$, densely hairy externally becoming sparsely glandular hairy on lobes. Stamens with filaments $9-11 \mathrm{~mm}$ long, glabrous, or with tuft of hairs at point of fusion with corolla tube, attached c. $20 \mathrm{~mm}$ from base of corolla; anthers facing one another and cohering at tips before dehiscence, 1-2 $\mathrm{mm}$ long; staminodes 3 , lateral staminodes c. $3 \mathrm{~mm}$ long, central staminode slightly longer and thinner, c. $4 \mathrm{~mm}$ long. Gynoecium 25-32 mm long; disc cupular, undulate with lobed, fringed margin, c. $2 \mathrm{~mm}$ long, glabrous; ovary and style densely eglandular hairy; stigma capitate to flattened. Fruits narrow ovoid to oblong, asymmetrical, c. $35 \times 6 \mathrm{~mm}$, hairy, base of style persistent, calyx persistent on young fruits.

Distribution. South Sulawesi: Latimojong Range (Figure 47).

Habitat and ecology. In tropalpine forest at an altitude of 2500-3000 m.

Etymology. The epithet purpureofucata, meaning 'painted purple', refers to the strong colouring on the reflexed corolla lobes (Bone \& Atkins, 2013).

Proposed IUCN conservation category. This species has an EOO of $12 \mathrm{~km}^{2}$ and an AOO of $12 \mathrm{~km}^{2}$, based on a $2 \times 2 \mathrm{~km}$ grid cell size, under the B criteria (Bachman et al., 2011). Cyrtandra purpureofucata has been collected on botanical expeditions to montane areas of South Sulawesi in 1929 and 1937, and more recently in 2000 and 2009 . All four specimens were collected in tropalpine vegetation at 2500-3000 m. Tropalpine and montane forests were ranked as the least endangered habitats of Sulawesi by Cannon et al. (2007), with a high proportion of tropalpine forest classed as 'Great to Good' in quality. The lack of identifiable threats or evidence of decline precludes any of the IUCN threat categories, so following Bone \& Atkins (2013), this species is considered Least Concern (LC).

Additional specimens examined. INDONESIA. South Sulawesi. Enrekang: Latimojong Mountains, Tinabang, West side of the Rante Mario, 3000 m, 17 vi 1937, Eyma 696 (A, BO, K, L, SING); ibid., B. Rante Mario [Buntu Rantemario], 2500 m, vi 1929, Kjellberg 4039 (BO, S); ibid., above Rantelemo, 2800 m, 6 iii 2000, Mendum, Argent \& Hendrian 00252 (BO, E, K, L). 


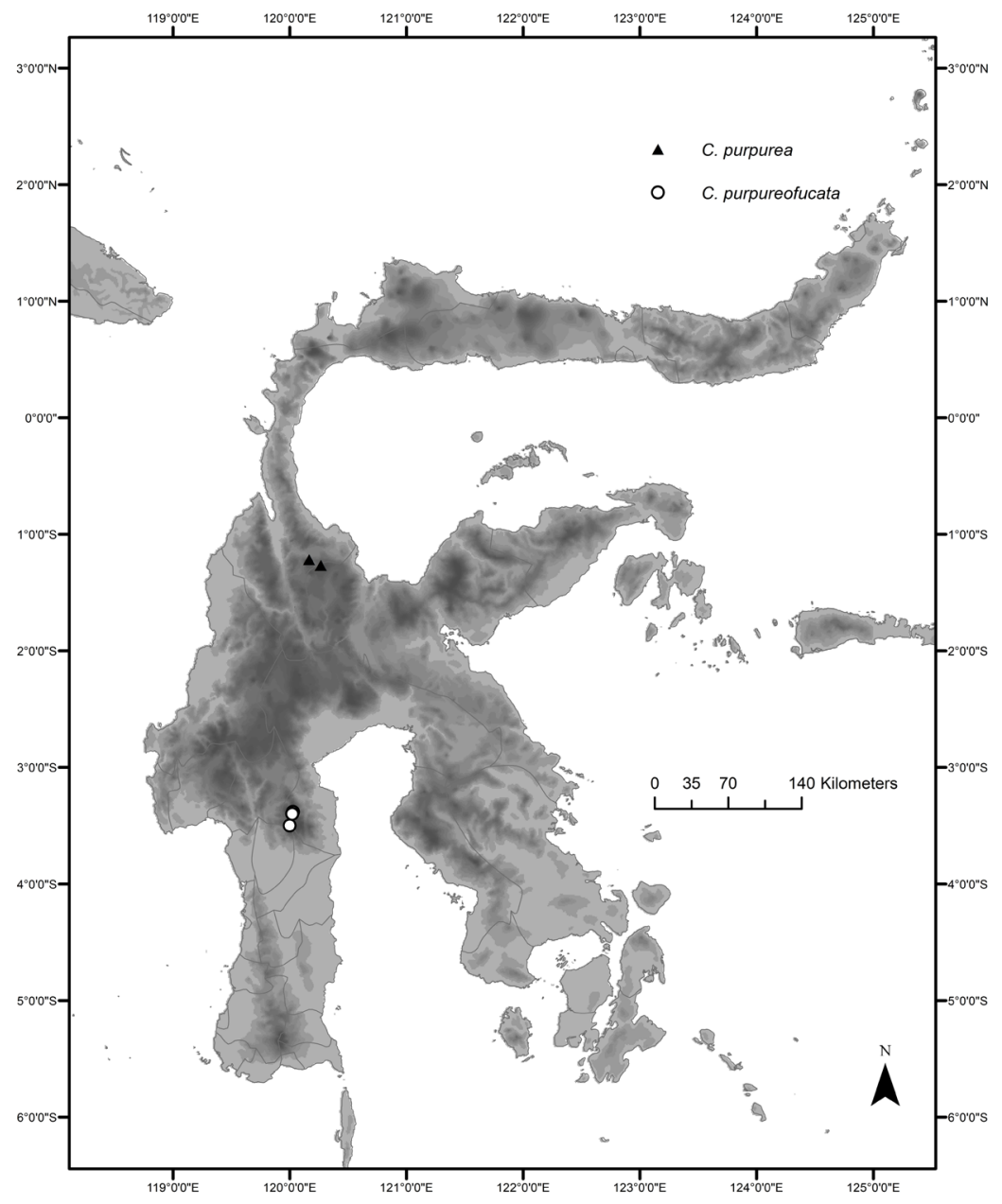

Figure 47. Distribution of Cyrtandra purpurea (black triangles) and C. purpureofucata (white circles).

Cyrtandra purpureofucata is a very distinctive species with its purple, pouched corolla with small, recurved lobes.

30. Cyrtandra rantemarioensis Karton. \& R.Bone, Edinburgh J. Bot. 75(2): 26 (2018). - Type: Indonesia, Sulawesi, South Sulawesi, Mt Rantemario, 5 iii 2000, Mendum et al. 00240 (holotype BO; isotypes E, L). Figure 48.

Branching subshrub to $2 \mathrm{~m}$ in height, often much shorter. Stems striate, greenish brown, glabrate, sparsely hairy on young growth. Leaves opposite, sometimes clustered at the ends of the stems, more or less equal; petioles $1.5-2 \mathrm{~cm}$ long, sparsely hairy; blades 8-20 $\times$ 1.8-5 cm, narrow oblong to oblanceolate, base acute, briefly decurrent, margin serrate, apex short acuminate; 5 or 6 pairs of lateral veins, tertiary venation loosely reticulate, mid to dark 


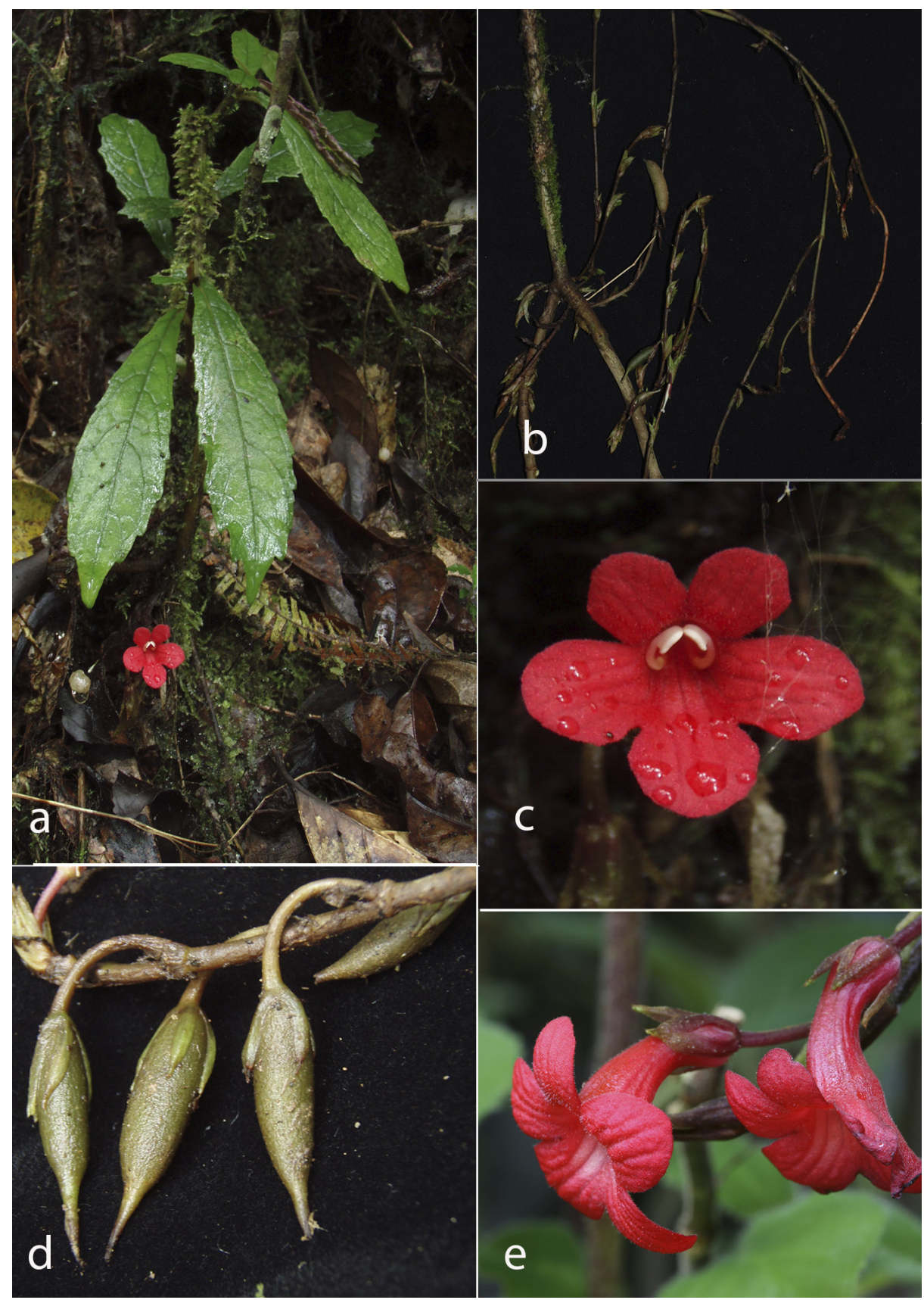

Figure 48. Cyrtandra rantemarioensis. a, Habit; b, trailing inflorescence; c, front view of flower; $d$, young fruits; e, side view of flower. Photographs: a-d, Axel Poulsen; e, Steve Scott. Specimen: Ardiyani et al. 165 (a-d) and Royal Botanic Garden Edinburgh (RBGE) accession 20000622K, vouchered as Scott 507 (e). Reproduced from Kartonegoro et al. (2018) with the permission of the Trustees of the RBGE. 
green, somewhat marbled and subglabrous to sparsely hairy above, much paler and flushed purple and subglabrous below, very sparsely hairy on midrib and veins. Inflorescences trailing from the base of the plant, or occasionally cauliflorous, inflorescence axis $40-50 \mathrm{~cm}$ or more long, striate, hairy when young, becoming glabrous with age, c. $1 \mathrm{~mm}$ in diameter with persistent bracteoles; bracts green to dull red, c. $25 \times 10 \mathrm{~mm}$, acuminate at apex, with serrate margins apically, hairy when young, particularly at the base and along veins, soon caducous, visible only at the tips of the inflorescence axis; bracteoles green to dull red, 10-15 × $2 \mathrm{~mm}$, linear to linear-lanceolate, acuminate at apex, sparsely hairy externally, often persistent on inflorescence axis; pedicels reddish, 10-15 mm long, hairy, elongating and becoming more glabrous in fruit. Calyx reddish when in flower turning green when fruiting, c. $6 \mathrm{~mm}$ long, upper lobes divided briefly at apex, lower lobes free to base, lobes acuminate, sparsely hairy externally. Corolla red, slightly paler in the mouth, 15-20 mm long, arcuate with a narrow tube widening to mouth, sparsely hairy externally, internally with scattered eglandular hairs and a dense covering of glandular hairs in the mouth, lobes spreading, slightly projected forwards, two upper lobes orbicular, c.7 $\times 7 \mathrm{~mm}$, lateral and lower lobes orbicular, 9-10 $\times 8 \mathrm{~mm}$. Stamens with filaments c. $2 \mathrm{~mm}$ long, attached c. $12 \mathrm{~mm}$ above the base of the corolla, white, glabrous; anthers 1-2 mm long, cohering at apices, glabrous, white; staminodes 3, c. $0.5 \mathrm{~mm}$ long. Gynoecium c. $10 \mathrm{~mm}$ long; disc c. $2 \mathrm{~mm}$ long, unilateral with undulate to lobed margin, glabrous; ovary densely hairy; style glandular hairy towards apex; stigma bilobed, lobes vertical, c. $1 \mathrm{~mm}$ across. Fruits oblong, glabrous, smooth, greenish brown (drying light brown), 15-30 × 4-8 mm; base of style and calyx persistent.

Distribution. South Sulawesi: Latimojong Range (see Figure 51).

Habitat and ecology. Montane and tropalpine forest at an altitude of $1500-2600 \mathrm{~m}$.

Etymology. Named after the mountain from where the type specimen was collected (Kartonegoro et al., 2018).

Proposed IUCN conservation category. The EOO of this species is $195 \mathrm{~km}^{2}$ and the AOO is $24 \mathrm{~km}^{2}$, based on a $2 \times 2 \mathrm{~km}$ grid cell size, under the B criteria (Bachman et al., 2011). It has been collected on eight different botanical expeditions in the Latimojong Range (between 1969 and 2010), suggesting that it is locally abundant and is found in montane forest sensu Cannon et al. (2007), which is one of the least threatened forest types in Sulawesi (70\% of upland forests above $1500 \mathrm{~m}$ elevation are intact). For this reason and following Kartonegoro et al. (2018), it is recommended that Cyrtandra rantemarioensis be considered as Least Concern (LC).

Additional specimens examined. INDONESIA. South Sulawesi. Enrekang: Latimojong Mountains, 28 i 2009, Ardiyani, Poulsen \& Firdaus 165 (E); ibid., on path to Mt Rantemario peak, 6 vii 2002, Brown, Craven \& Juswara 4 (BO); ibid., 15 vi 1937, Eyma 467 (BO, L); ibid., Buntu Kaciling, 11 vi 2010, Kartonegoro \& Santoso ARK475 (BO); ibid., Rantelemo, v 1929, Kjellberg 4040 (BO, S); ibid., 30 x 
1969, Sands 307 (K); Mt Rantemario, 5 iii 2000, Smith \& Galloway 229, grown at RBGE as accession 20000622K, vouchered as Scott 507 (E); ibid., 23 iv 2009, Thomas \& Ardi 09-79 (BO, E); ibid., 24 iv 2009, Thomas \& Ardi 09-81 (BO, E, L).

Cyrtandra rantemarioensis is one of four species in Sulawesi that have long, trailing inflorescences originating at the base of the plant (the others are C. geocarpa, C. hypogaea and $C$. luteiflora). This species can most easily be distinguished in this group by its red flowers and oblong fruits that, although wrinkled when dry, are not as distinctly tessellate as the fruits of Cyrtandra hypogaea.

31. Cyrtandra roseiflora H.J.Atkins, Edinburgh J. Bot. 60(3): 318 (2004). - Type: Indonesia, Sulawesi, Central Sulawesi, Mt Sojol, 26 ii 2000, Mendum et al. 00173 (holotype BO; isotypes E, L). Figure 49.

Shrub to $1 \mathrm{~m}$ in height. Stems slender, striate, subglabrous. Leaves opposite, subequal or one in each pair markedly reduced; petiole 3-4 mm long, subglabrous; blades of developed leaves $6-11 \times 1.5-3 \mathrm{~cm}$, narrow oblong to narrow elliptic, base acute and more or less symmetrical at base, not decurrent, margin serrate, apex acuminate; 5-7 pairs of lateral veins, occasionally looping and joining with vein above and with short veins running to the teeth, glabrous above and below. Reduced leaves c. $4 \times 2 \mathrm{~mm}$, cordate. Inflorescences axillary and at the base of stems in axils of fallen leaves, 1- or 2-flowered, sessile; pedicel 5-7 mm long, sparsely hairy; bracts 2-4 mm long, linear, sparsely hairy, not connate. Calyx narrow campanulate, light green to brown, 12-14 mm long, slightly bilabiate, lobes subulate, upper lobes c. $6 \mathrm{~mm}$ long, lower lobes c. $7 \mathrm{~mm}$ long, sparsely hairy. Corolla pale red outside, paler internally, in tube and throat, 30-35 mm long, narrow funnel-shaped, gradually widening to mouth, slightly pouched on lower side, arcuate, lobes rounded, not recurved, c.7 $77 \mathrm{~mm}$, hairy externally, subglabrous internally. Stamens with filaments $3-5 \mathrm{~mm}$ long, attached 20-22 mm from base of corolla, glabrous; anthers $2 \mathrm{~mm}$ long, cohering at apices and face to face before dehiscence; staminodes 2, less than $1 \mathrm{~mm}$ long. Gynoecium 11-22 mm long; disc cupular, with undulate, fringed margin, 2-2.5 mm long; ovary and style eglandular hairy; stigma bilobed, lobes $1 \mathrm{~mm}$, pressed together. Fruits ovoid, c. $5 \times 3 \mathrm{~mm}$ (immature?), sparsely hairy, calyx and base of style persistent.

Distribution. Central and South Sulawesi (see Figure 51).

Habitat and ecology. Montane forest at an altitude of 1500-1800 m.

Etymology. This species is named for its pale red flowers (Atkins, 2004).

Proposed IUCN conservation category. Cyrtandra roseiflora is known from only two locations, so it has not been possible to calculate an EOO, but it has an AOO of $8 \mathrm{~km}^{2}$, based on a $2 \times$ $2 \mathrm{~km}$ grid cell size, under the B criteria (Bachman et al., 2011). The type collection is from Mount Sojol Nature Reserve in Central Sulawesi, which has protected status (UNEP-WCMC 


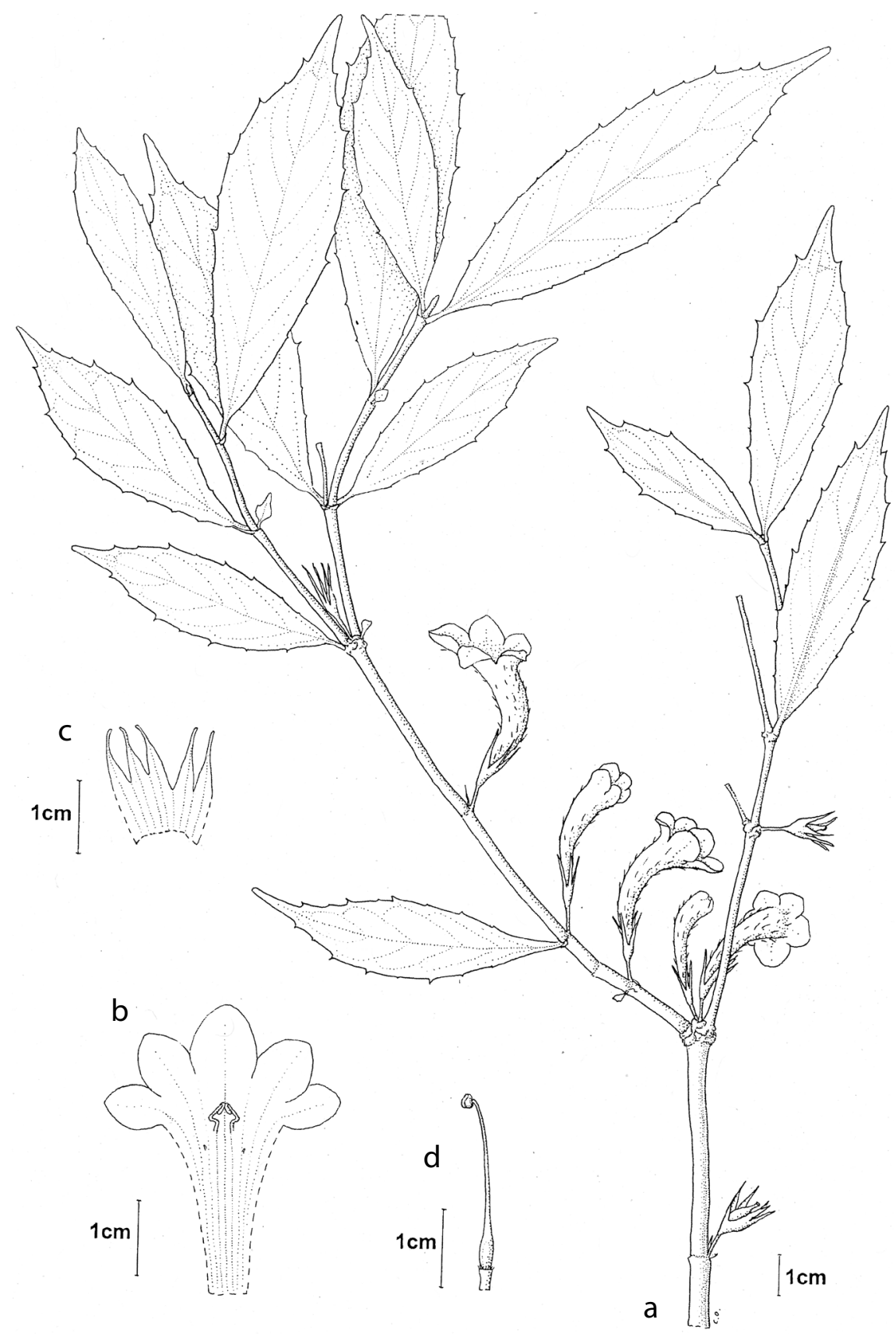

Figure 49. Cyrtandra roseiflora. a, Habit; b, opened corolla, showing position of stamens and staminodes; c, opened calyx, showing inner surface; d, gynoecium including disc. Drawn by Christina Oliver from Mendum et al. 00173. Reproduced from Atkins (2004) with the permission of the Trustees of the Royal Botanic Garden Edinburgh. 
\& IUCN, 2019), and the second is from Mount Sesean, which has no formal protection. They are both from montane forest at altitudes of 1500 and $1800 \mathrm{~m}$, which is less threatened than lowland areas, with $70 \%$ of forest at this altitude in 'Great to Good' condition (Cannon et al., 2007). It is suggested that this species is considered Least Concern (LC).

Additional specimen examined. INDONESIA. South Sulawesi. North Toraja: Mt Sesean, 7 xi 2018, Ardi WI345 (KRB).

Cyrtandra roseiflora can be distinguished from others in Sulawesi by its glabrous, serrate leaves, and pale red flowers with white throat. The specimen Rachmat 1002a (BO), cited under the original description, is part of a mixed collection with some sheets containing a different species. To avoid later confusion, this specimen has not been included in the list of additional collections here.

32. Cyrtandra rubribracteata Karton. \& H.J.Atkins, Edinburgh J. Bot. 75(2): 29 (2018). Type: Indonesia, Sulawesi, Central Sulawesi, Luwuk Regency, Mt Hek, 28 ii 2004, Hendrian, Newman, Scott, Saleh. \& Supriadi 968 (holotype BO, isotype E). Figure 50.

Shrub or small tree to $1.8 \mathrm{~m}$ in height. Stems cylindrical, striate, glabrous. Leaves opposite, subequal; petioles $1.5-2 \mathrm{~cm}$ long, glabrous; blades $14-25 \times 2-3.5 \mathrm{~cm}$, narrow oblong to lorate or narrow oblanceolate, base decurrent, margin serrate, occasionally biserrate, apex acuminate; 5-7 pairs of lateral veins curving sharply upwards and faint tertiary venation, dark green and glabrous above, whitish green and glabrous below. Inflorescences axillary, sessile, c.6-flowered; bracts ovate, paired, dark, dull red, c. $30 \times 20 \mathrm{~mm}$, tough, leathery, joined very briefly at the base and forming an involucre with serrate margins, glabrous externally, enclosing the flowers and fruit; bracteoles c. $40 \times 10 \mathrm{~mm}$, some much smaller, narrow-lanceolate with serrate margins, leathery, glabrous; pedicels 4-6 mm long, hairy. Calyx tubular, pink, 30-36 mm long, lobes 9-17 mm long, acuminate, ridged along the length of the tips, hairy externally. Corolla white, $42-45 \mathrm{~mm}$ long, held upright in involucre, narrow in basal $1 / 3$, widening to mouth in upper $2 / 3$, upper lobes rounded, $5-6 \times 4-5 \mathrm{~mm}$, lower and lateral lobes rounded 8-9 $\times 7-8 \mathrm{~mm}$, distinctive ridges running along base of the tube, densely hairy externally. Stamens with filaments c. $10 \mathrm{~mm}$ long, attached c. $20 \mathrm{~mm}$ above the base of the corolla, straight at the base, curved over slightly at the top, glabrous with a few glandular hairs at the apex; anthers c. $1 \mathrm{~mm}$ long, glabrous, drying much darker than the filaments, with a distinctive pointed tip appearing like a hook or beak, not coherent; staminodes 3, c. $5 \mathrm{~mm}$ long. Gynoecium c. $30 \mathrm{~mm}$ long; disc cupular with undulate margin, c. $2 \mathrm{~mm}$ long, glabrous; ovary glabrous at the base becoming densely hairy after c. $4 \mathrm{~mm}$ with the margin of indumentum somewhat lobed; style densely hairy; stigma bilobed, lobes vertical or spreading, c. $3 \times 2 \mathrm{~mm}$, with short glandular hairs. Fruits ovoid (immature), c. $15 \times$ $11 \mathrm{~mm}$, glabrous at the base, more densely hairy at apex; style and calyx not persistent.

Distribution. Central Sulawesi: Banggai Regency (Figure 51). 


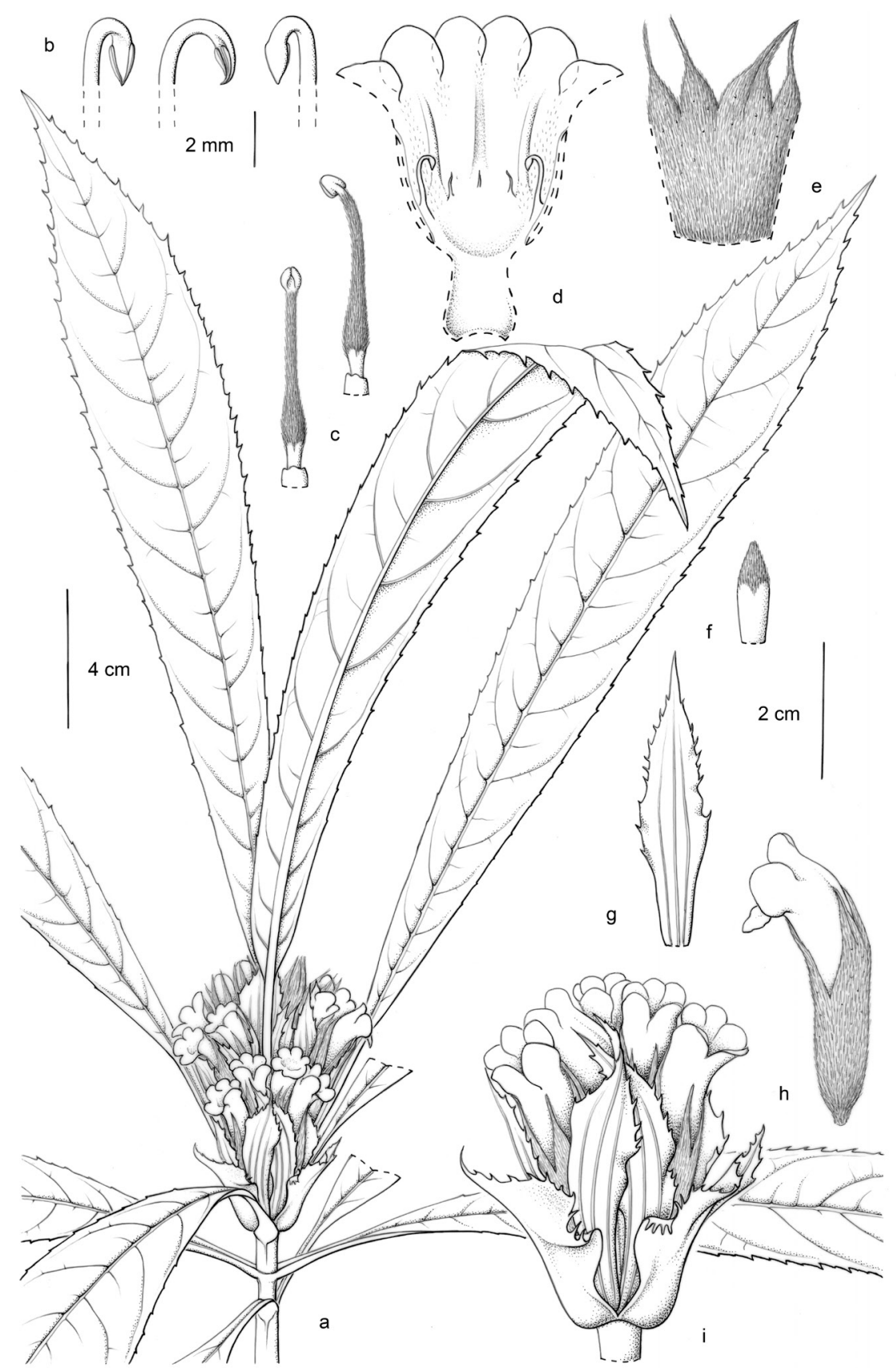

Figure 50. Cyrtandra rubribracteata. a, Habit; b, anthers; c, gynoecium including disc; $d$, opened corolla, showing position of stamens and staminodes; e, opened calyx; fruit; $g$, bracteole; $h$, side view of corolla; i, inflorescence. Drawn by Claire Banks from Hendrian et al. 968. Reproduced from Kartonegoro et al. (2018) with the permission of the Trustees of the Royal Botanic Garden Edinburgh. 


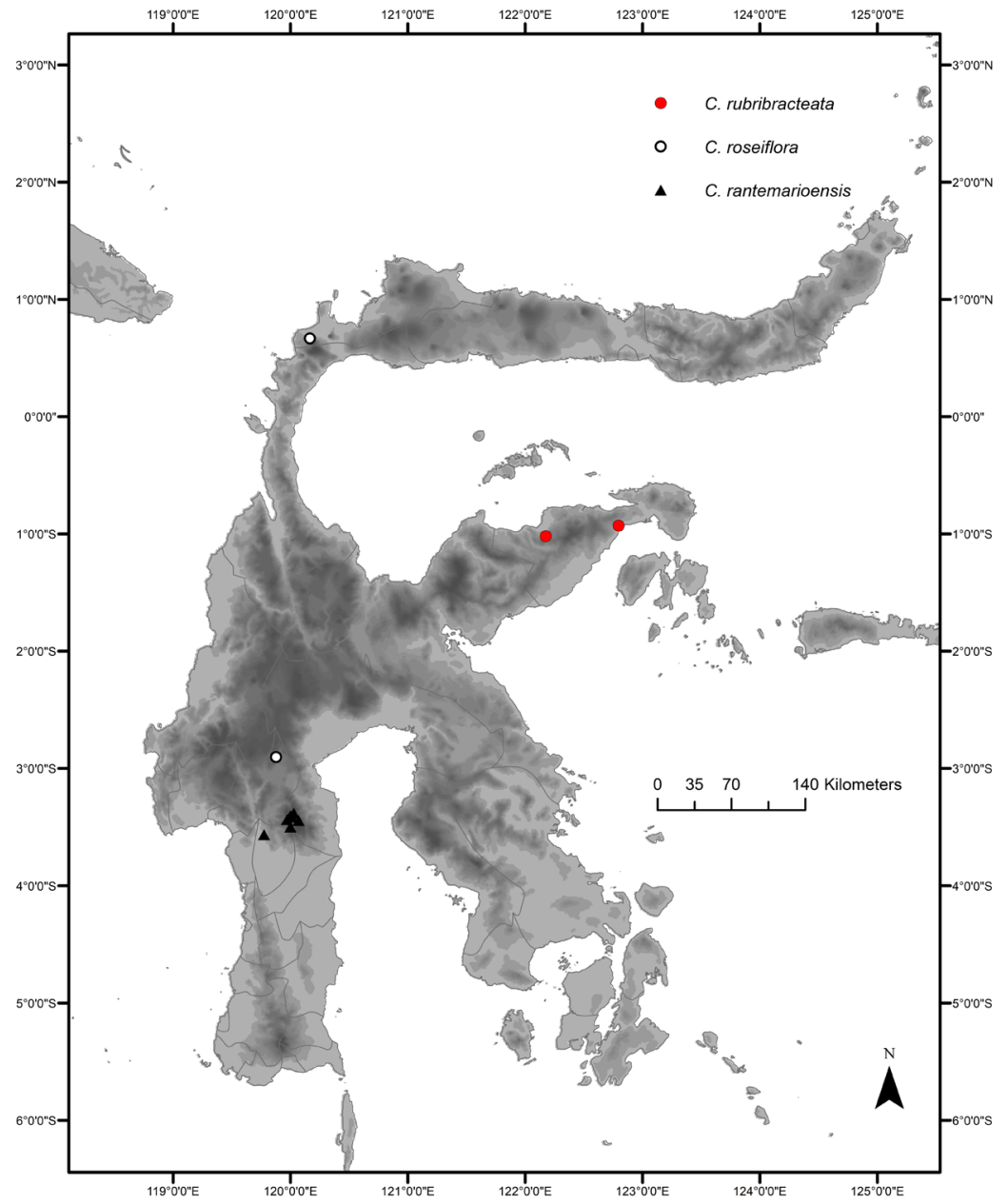

Figure 51. Distribution of Cyrtandra rantemarioensis (black triangles), C. roseiflora (white circles) and C. rubribracteata (red circles).

Habitat and ecology. Upland forest at an altitude of c.980 m.

Etymology. This species is named for its distinctive red bracts (Kartonegoro et al., 2018).

Proposed IUCN conservation category. Cyrtandra rubribracteata has an AOO of $8 \mathrm{~km}^{2}$, based on a $2 \times 2 \mathrm{~km}$ grid cell size (Bachman et al., 2011). It has been possible to accurately georeference only one of the collection localities: that of the type specimen, Hendrian et al. 968 , from Mount Hek. This collection was made at $980 \mathrm{~m}$ in upland forest, which is one of the more threatened habitat types in Sulawesi (Cannon et al., 2007). Satellite imagery shows signs of habitat degradation at the lower altitudes of Mount Hek. The other collection (Eyma 3909) has the locality description of 'limestone plateau' in the subdivision of Luwuk, 
and no protected area has been recorded in that general area (UNEP-WCMC \& IUCN, 2019). Kartonegoro et al. (2018) suggest Vulnerable (VU) for this species, but we consider there to be continuous habitat degradation and assess the species as Endangered (EN), B2ab(iii).

Additional specimen examined. INDONESIA. Central Sulawesi. Banggai: between Camp I and Camp II on limestone plateau, 28 ix 1938, Eyma 3909 (BO, K, L).

Cyrtandra rubribracteata can be distinguished from other Sulawesi Cyrtandra by its narrow oblong leaves with serrate margins; large, dull-red inflorescence bracts; and unusual, somewhat beaked, anthers. No other species from Sulawesi recorded so far has these distinctive anther appendages. There are, however, a number of species from Borneo recorded with a 'conspicuous apiculus' on the anthers, such as Cyrtandra paxiana Lauterb. and $C$. prostrata Kraenzl.

33. Cyrtandra sandei de Vriese, PI. Ind. Bat. Orient. 14 (1856). - Type: Indonesia, Celebes [Sulawesi], Lontar, Reinwardt s.n. (lectotype L [L0003193], designated here).

Shrub to $2 \mathrm{~m}$ in height. Leaves opposite, subequal; petioles c. $10 \mathrm{~mm}$ long, sparsely hairy; blades 16-19 × 5-9 cm; narrow obovate, base decurrent, margin serrate, apex acuminate, 17-20 pairs of lateral veins, glabrous above, sparsely hairy below, more densely so on midrib and veins. Inflorescences axillary, sometimes below current leaves; sessile; bracts narrow ovate, acuminate at apex, up to $12 \times 3 \mathrm{~mm}$, hairy. Calyx $6 \mathrm{~mm}$ long, lobes triangular, acuminate at apex, c. $2 \mathrm{~mm}$ long, hairy externally. Corolla pale green-yellow with reddish brown markings in the throat, c. $18 \mathrm{~mm}$ long, narrow in basal $1 / 3$, widening to mouth in upper $2 / 3$, upper lobes rounded, c. $2 \times 3 \mathrm{~mm}$, lower and lateral lobes rounded c. $3 \times 4 \mathrm{~mm}$, densely hairy externally. Stamens with filaments c. $6 \mathrm{~mm}$ long, glabrous with a few glandular hairs at the apex; anthers c. $1.5 \mathrm{~mm}$ long, face to face and connected at tips before dehiscence; staminodes 3 , two lateral ones c. $1.5 \mathrm{~mm}$ long, central one c. $0.5 \mathrm{~mm}$ long. Gynoecium c. $10 \mathrm{~mm}$ long; disc unilateral, c. $2 \mathrm{~mm}$ long, glabrous; ovary and style densely eglandular hairy, stigma bilobed, c. $1 \mathrm{~mm}$ across. Fruits oblong, c. $20 \times 5 \mathrm{~mm}$, hairy, calyx and base of style persistent.

Distribution. [Lontar] in Sulawesi (this locality could be Lota in North Sulawesi, because all Reinwardt's collection localities are in the north of the island and Lota is listed as one of these (van Steenis, 1950); Java and Sumatra.

Habitat and ecology. There is no information on the collection from Sulawesi, but the collections from Java and Sumatra were collected over a wide altitudinal range, from 100 to $1400 \mathrm{~m}$.

Etymology. This species is named after C. M. van der Sande Lacoste, a medical doctor and good friend of de Vriese who studied cryptogamic plants (de Vriese, 1856).

Proposed IUCN conservation category. This species is recorded from Sulawesi, Java (Bakhuizen van den Brink, 1950) and Sumatra (fide Bakhuizen van den Brink K, L) and, as 
such, has one of the widest distributions of Cyrtandra species in the region. The locality of the single collection of Cyrtandra sandei from Sulawesi, which is the type, is not known, so a category of Data Deficient (DD) is recommended for this species.

Cyrtandra sandei is known, in Sulawesi, only from the type collection. It is most similar, in Sulawesi, to $C$. jellesmanii, in having subequal, decurrent leaves, non-tessellate stems, narrow inflorescence bracts and densely eglandular hairy ovaries. It can be most easily distinguished from this species by its much smaller flowers $(18 \mathrm{~mm}$ long versus $45 \mathrm{~mm}$ long) and unilateral (as opposed to cupular) nectary disc.

The description here of Cyrtandra sandei is brief and has been compiled from the single Sulawesi collection (the type specimen), de Vriese's original description, and supplemented with information from literature (Clarke, 1883; Bakhuizen van den Brink, 1950). A detailed review of all the collections across the distribution of Cyrtandra sandei is needed to confirm that those from Java, Sumatra and Sulawesi are all the same species, and to capture the full intraspecific variation.

34. Cyrtandra serratifolia H.J.Atkins, Edinburgh J. Bot. 60(3): 313 (2004). - Type: Indonesia, Sulawesi, North Sulawesi, Bolaang Mongondow, 16 iv 1985, de Vogel \& Vermeulen 7202 (holotype BO; isotypes $\mathrm{E}, \mathrm{K}, \mathrm{L}$ ). Figures 52,53 .

Erect or creeping shrub to $30 \mathrm{~cm}$ in height. Stems longitudinally striate, hairy, more densely so when young. Leaves opposite, sometimes in threes; all well developed but somewhat unequal in size; petiole $1-4 \mathrm{~mm}$ long, hairy to densely hairy; blades $0.5-3 \times 0.4-1.2 \mathrm{~cm}$, wide elliptic, base obtuse, margin serrate, apex rounded to short acuminate; 3 or 4 pairs of lateral veins, occasionally with short veins running to adjacent teeth, sparsely hairy, more densely so on midrib and margins above and midrib and veins below. Inflorescences axillary, sessile, 1- or 2-flowered; bracts 3-5 $1 \mathrm{~mm}$, linear hairy; pedicels 4-5 mm long, hairy. Calyx green, 7-9 mm long, with 5 equal subulate lobes, $5-6 \mathrm{~mm}$ long, hairy externally, most densely so at median line of lobes and at their tips. Corolla pink or red, $20-26 \mathrm{~mm}$ long, funnel-shaped, slightly arcuate, lobes rounded, upper lobes $5-6 \times 7-8 \mathrm{~mm}$, lower lobes 6-7 $\times 5-6 \mathrm{~mm}$, hairy externally. Stamens with filaments c. $2 \mathrm{~mm}$ long, attached 12-14 mm from base of corolla, filaments with some sessile glands; anthers c. $1.5 \mathrm{~mm}$ long, cohering at apices before dehiscence; staminodes 3 , all less than $1 \mathrm{~mm}$ long. Gynoecium 9-13 mm long; disc cupular, undulate, c. $1 \mathrm{~mm}$ long, glabrous; ovary subglabrous at base becoming glandular hairy towards style; style glandular hairy; stigma bilobed, lobes c. $3 \mathrm{~mm}$ across. Fruits ovoid, c. $10 \times 5 \mathrm{~mm}$ (possibly immature), subglabrous but with glandular hairs at base of persistent style; calyx persistent.

Distribution. North Sulawesi and Gorontalo (see Figure 55).

Habitat and ecology. Upland and montane forest at an altitude of 1300-1800 m.

Etymology. This species is named for its distinctive serrate leaves (Atkins, 2004). 


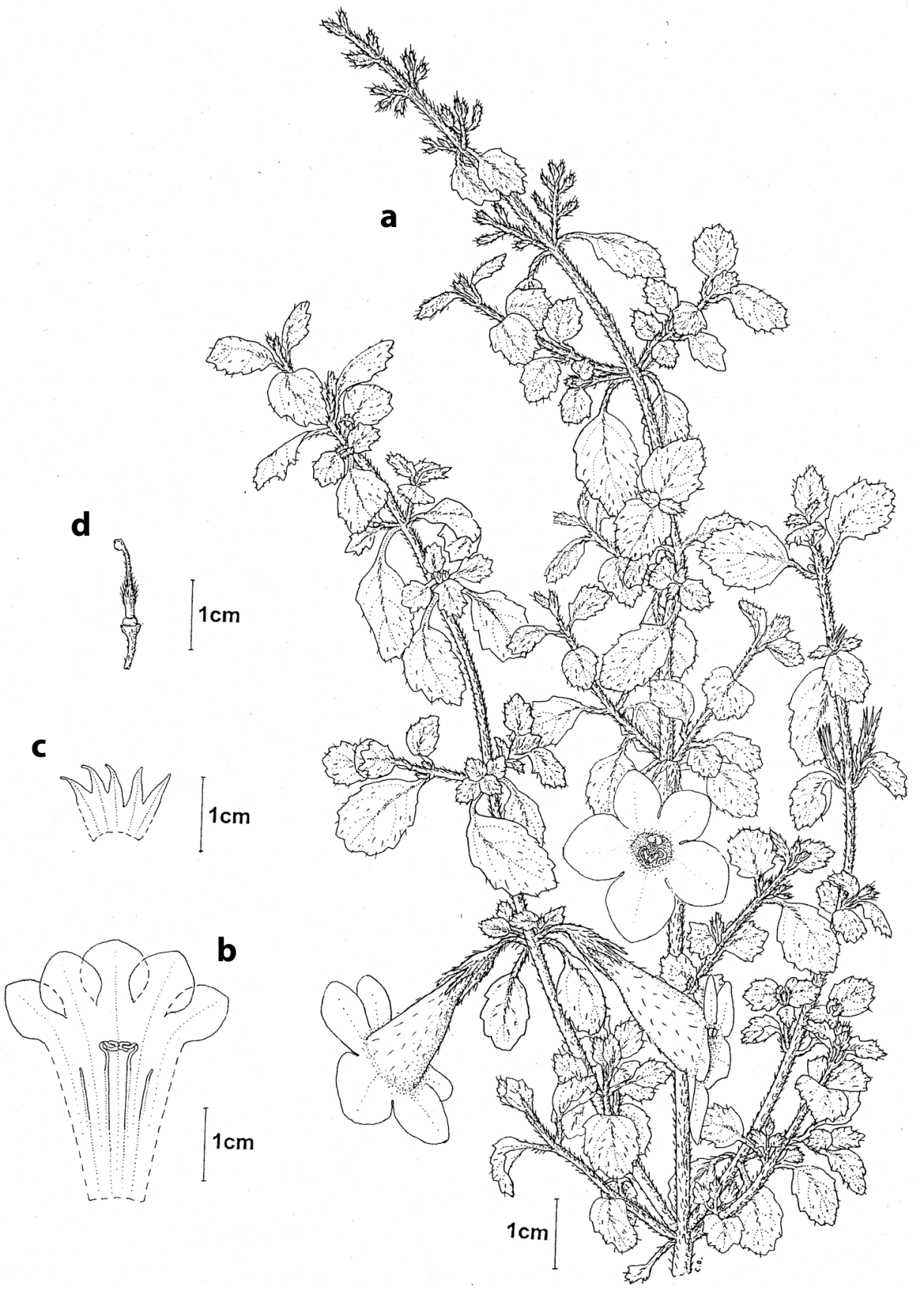

Figure 52. Cyrtandra serratifolia. a, Habit; b, opened corolla, showing position of stamens and staminodes; c, opened calyx, showing inner surface; d, gynoecium including disc. Drawn by Christina Oliver from Atkins et al. 93. Reproduced from Atkins (2004) with the permission of the Trustees of the Royal Botanic Garden Edinburgh. 

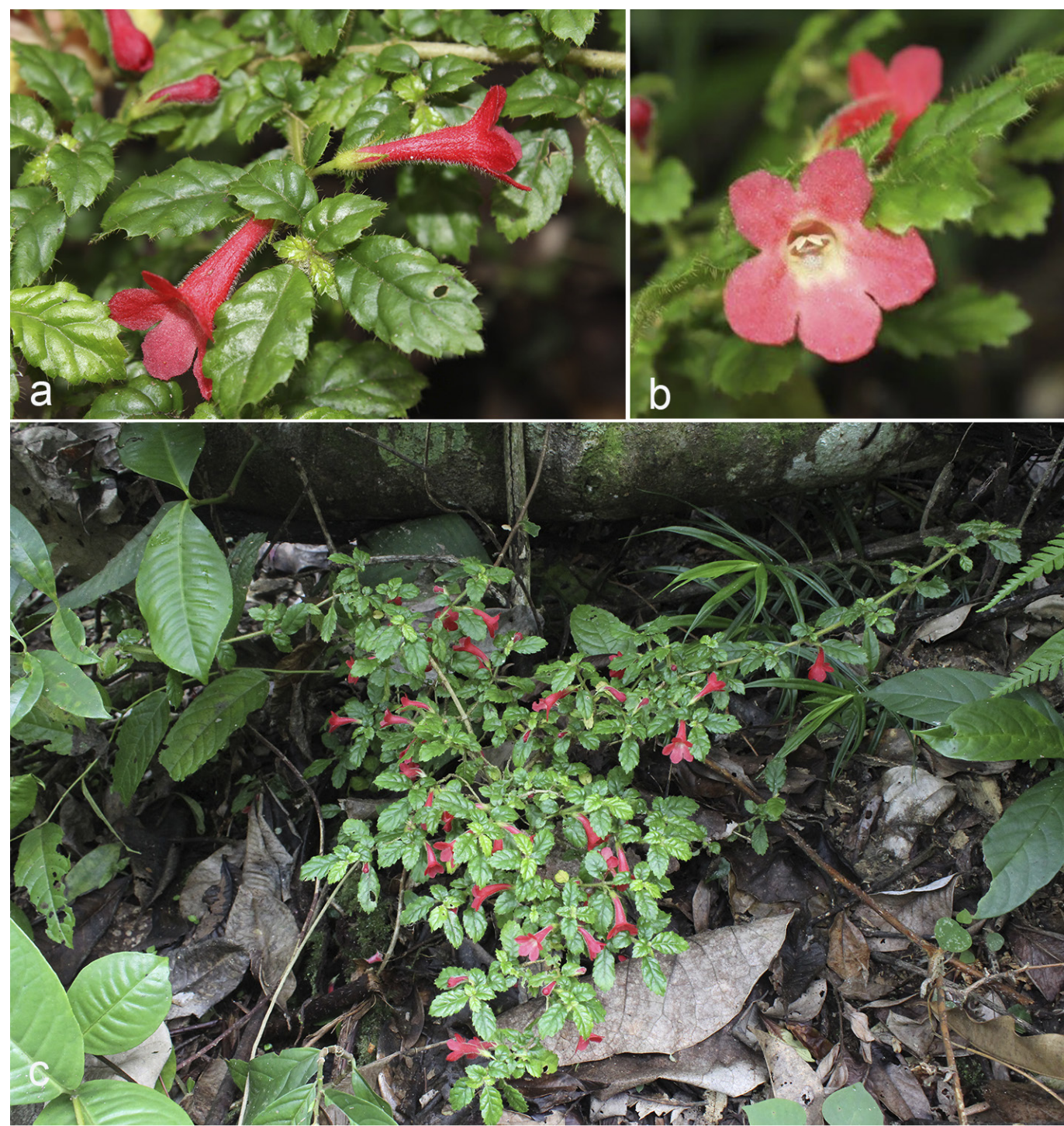

Figure 53. Cyrtandra serratifolia. a, Side view of flower; b, front view of flower; c, habit. Photographs: Sadie Barber. Specimen: Barber et al. BAKK54.

Proposed IUCN conservation category. The EOO of Cyrtandra serratifolia is $1811 \mathrm{~km}^{2}$ and the $\mathrm{AOO}$ is $20 \mathrm{~km}^{2}$, based on a $2 \times 2 \mathrm{~km}$ grid cell size, under the B criteria (Bachman et al., 2011). The collections are from relatively high-altitude forest, which is less threatened in Sulawesi (Cannon et al., 2007) than the lowland areas, and from within the protected areas of Mount Ambang Nature Reserve and Bogani Nani Wartabone National Park (UNEP-WCMC \& IUCN, 2019). Because of its distribution entirely within protected areas, a category of Least Concern (LC) is given for this species. 
Additional specimens examined. INDONESIA. North Sulawesi. Bolaang Mongondow: viii 1917, Kaudern 184 (BO); Dumoga Bone National Park [Bogani Nani Wartabone], 26 ix 1991, Milliken 1064 (E, L); East Bolaang Mongondow: Mt Ambang Nature Reserve, 2 xi 2016, Barber, Atkins, Kartonegoro \& Kinho BAKK44 (BO, E); ibid., 3 xi 2016, Barber, Atkins, Kartonegoro \& Kinho BAKK54 (BO, E).

Gorontalo. Bone Bolango: Mt Gambuta, 12 iv 2002, Atkins et al. 93 (BO, E); ibid., 12 iv 2002, Scott 02-82, grown on at RBGE as accession 20021210A, vouchered as Atkins 10 (E); ibid., 12 iv 2002, Scott 02-82, grown on at RBGE as accession 20021210A, vouchered as Cubey \& Scott 255 (E).

Cyrtandra serratifolia differs from any other yet seen from Sulawesi in its tiny serrate leaves and low scrambling habit. It does, however, share this habit and leaf shape with Cyrtandra tarsodes B.L.Burtt from very high-altitude areas in New Guinea and C. auriculata C.B.Clarke and $C$. zamboengensis Merr. from the Philippines. There seems to be some variation in corolla colour, with the recent collections from Mount Ambang having much brighter red corollas than those from Mount Gambuta, which are a paler, slightly metallic pink. These differences were observed both in the wild populations and in cultivation.

35. Cyrtandra spectabilis R.Bone \& H.J.Atkins, Edinburgh J. Bot. 70(3): 463 (2013) Type: Indonesia, Sulawesi, South Sulawesi, Subdivision Enrekang District, Latimojong Mountains, 1 xi 1969, Sands 331 (holotype E; isotypes BO, K). Figure 54.

Erect, spreading shrub to $2.5 \mathrm{~m}$ in height. Stems terete, glabrescent or sparsely hairy. Leaves opposite; one leaf of a pair markedly reduced or appearing alternate; petiole 4-10 mm long, hairy; blades of larger leaves 8-11 × 2-3.2 cm, narrow elliptic, narrow oblong or oblanceolate, base acute, margin serrate, serrations irregularly and distantly spaced (c.5-24 mm apart), with small tufts of hair at apex, apex acute; 5-7 pairs of secondary veins, upper surface glabrous, lower surface hairy on midrib and veins, juvenile leaves more densely hairy. Reduced leaves (where present) elliptic, c. $10 \times 4 \mathrm{~mm}$. Inflorescences axillary, 1- or 2-flowered, or cauliflorous fascicles of up to 7 pendulous flowers; peduncles short, 2-4 mm long, hairy; bracts c.2-3 mm long, linear to oblanceolate, hairy, leafy (with midrib); pedicels 30-40 mm long, slender, glabrescent to sparsely hairy. Calyx maroon, 20-25 mm long, split on ventral side c. $1 / 4$ to $1 / 2$ the length of the calyx, upper lobes c.4-7 mm long (in immature flowers the calyx is not so deeply divided on the lower side and the calyx is more obscurely bilabiate), hairy externally. Corolla very pale yellow to cream, $30-40 \mathrm{~mm}$ long, funnelform, tube narrow at base, gradually widening to mouth, lobes c.7 $\times 6 \mathrm{~mm}$, glabrous internally, eglandular hairy externally. Stamens with filaments c. $11 \mathrm{~mm}$ long, cream, glabrous, attached c.24 mm from base of corolla; anthers c. $1.5 \mathrm{~mm}$ long, cohering at apices before anthesis; staminodes 3 , lateral staminodes c. $1 \mathrm{~mm}$ long, central less than $1 \mathrm{~mm}$ long. Gynoecium c.30 mm long; disc cupular, undulate with lobed margin, c. $1.2 \mathrm{~mm}$ long, glabrous; ovary densely eglandular hairy; style white, sparsely glandular hairy; stigma peltate, c. $0.8 \mathrm{~mm}$ across. Fruits not seen.

Distribution. South Sulawesi: Latimojong Range (see Figure 55). 


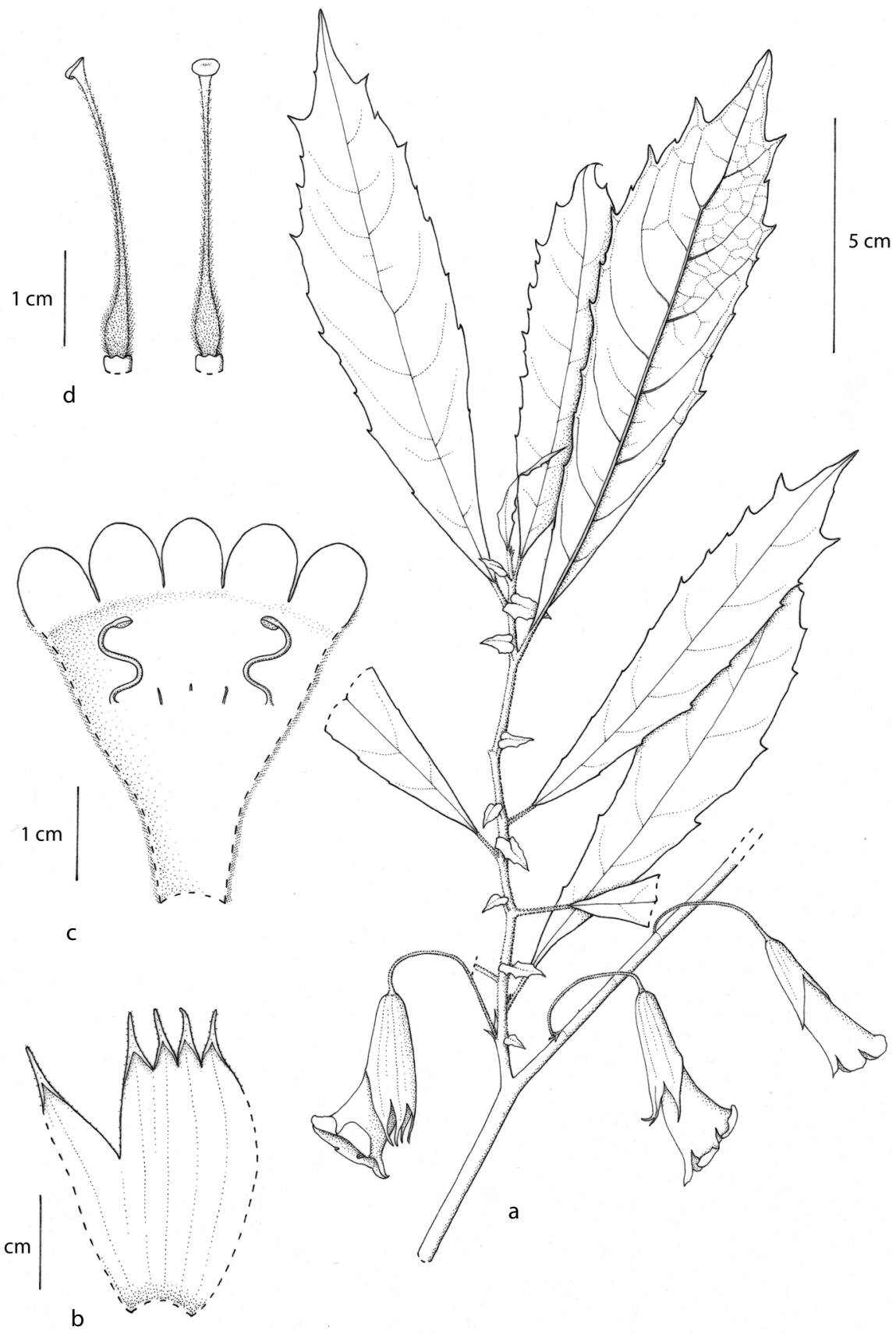

Figure 54. Cyrtandra spectabilis. a, Habit; b, opened calyx, showing inner surface; c, opened corolla, showing position of stamens and staminodes; $d$, gynoecium and disc. Drawn by Claire Banks from Sands 331. Reproduced from Bone \& Atkins (2013) with the permission of the Trustees of the Royal Botanic Garden Edinburgh. 
Habitat and ecology. Montane forest at an altitude of $1900 \mathrm{~m}$.

Etymology. This striking species with large, yellow flowers and a maroon calyx was given the epithet spectabilis, meaning 'attractive' (Bone \& Atkins, 2013).

Proposed IUCN conservation category. Cyrtandra spectabilis is known only from the type material. The $\mathrm{AOO}$ of this species is $4 \mathrm{~km}^{2}$, based on a $2 \times 2 \mathrm{~km}$ grid cell size, under the B criteria (Bachman et al., 2011). It was collected in 1969 from a relatively high altitude, and although Cannon et al. (2007) rank the threats to montane forests in Sulawesi as low, 'moderate to strong anthropogenic disturbance' has been reported in primary forest in the Latimojong Mountains between 1300 and $2200 \mathrm{~m}$ a.s.l. (Thomas et al., 2011) and there is no formal protection for this area (UNEP-WCMC \& IUCN, 2019). This species is considered as Critically Endangered (CR), B2ab(iii) to reflect its restricted distribution and our current understanding of continuous threat. Protection of the habitat and ex situ conservation are recommended.

Cyrtandra spectabilis is a very distinctive species, with its pendulous yellow flowers and maroon, membranaceous calyx. It is unlike any other species in Sulawesi.

36. Cyrtandra spicata de Vriese, PI. Ind. Bat. Orient. 13 (1856). - Rhynchocarpus spicatus Reinw. ex de Vriese, PI. Ind. Bat. Orient. 13 (1856), nom. inval. - Type: Indonesia, Celebes [Sulawesi], North Sulawesi, in sylvis montis Klabat, xi 1821, Reinwardt mss no. 1571 (lectotype L [L0277522], designated here; isolectotype L [L0277524]).

Shrub or small tree to $5 \mathrm{~m}$ in height. Leaves opposite or in threes, crowded at ends of branches; those of a group or pair well developed but somewhat unequal in size; petiole up to $5 \mathrm{~mm}$ long, hairy; blades $15-30 \times 4.5-13 \mathrm{~cm}$, oblanceolate to narrow obovate, base decurrent and white, margin serrate-dentate, apex acute; 7-10 pairs of lateral veins, curving upwards and running out to margin with some lateral veins running out to adjacent teeth, upper surface of leaves subglabrous, sparsely hairy below, more densely so on midrib and veins. Inflorescences pendulous from branches, inflorescence axis up to $25 \mathrm{~cm}$ long, many-flowered, flowers clustered terminally, axis appearing scaly from the remains of old bracts; bracts up to $25 \mathrm{~mm}$ long, broad, possibly ovate, sparsely hairy. Calyx tubular, $20-25 \mathrm{~mm}$ long, more or less evenly 5-lobed, lobes triangular, $5 \mathrm{~mm}$ long, hairy externally. Corolla pale pink, 23-30 mm long, barely longer than the calyx, curved and slightly swollen below the throat, lobes unequal, upper lobes much smaller, sparsely hairy externally. Stamens with filaments $3-4 \mathrm{~mm}$ long, curved; anthers c. $2 \mathrm{~mm}$ long, connected at apices before dehiscence; staminodes 3, c. $1 \mathrm{~mm}$ long. Gynoecium c. $15 \mathrm{~mm}$ long (damaged at base); disc not seen; ovary not seen; style glandular at the top of the style near the stigma, glabrous towards the ovary; stigma bilobed, lobes vertical, possibly immature, $2 \mathrm{~mm}$ long, densely glandular on inner surface of lobes. Fruits ovoid, 10-11 × 6-7 mm, glabrous, calyx and base of style not persistent.

Distribution. North Sulawesi (Figure 55). 


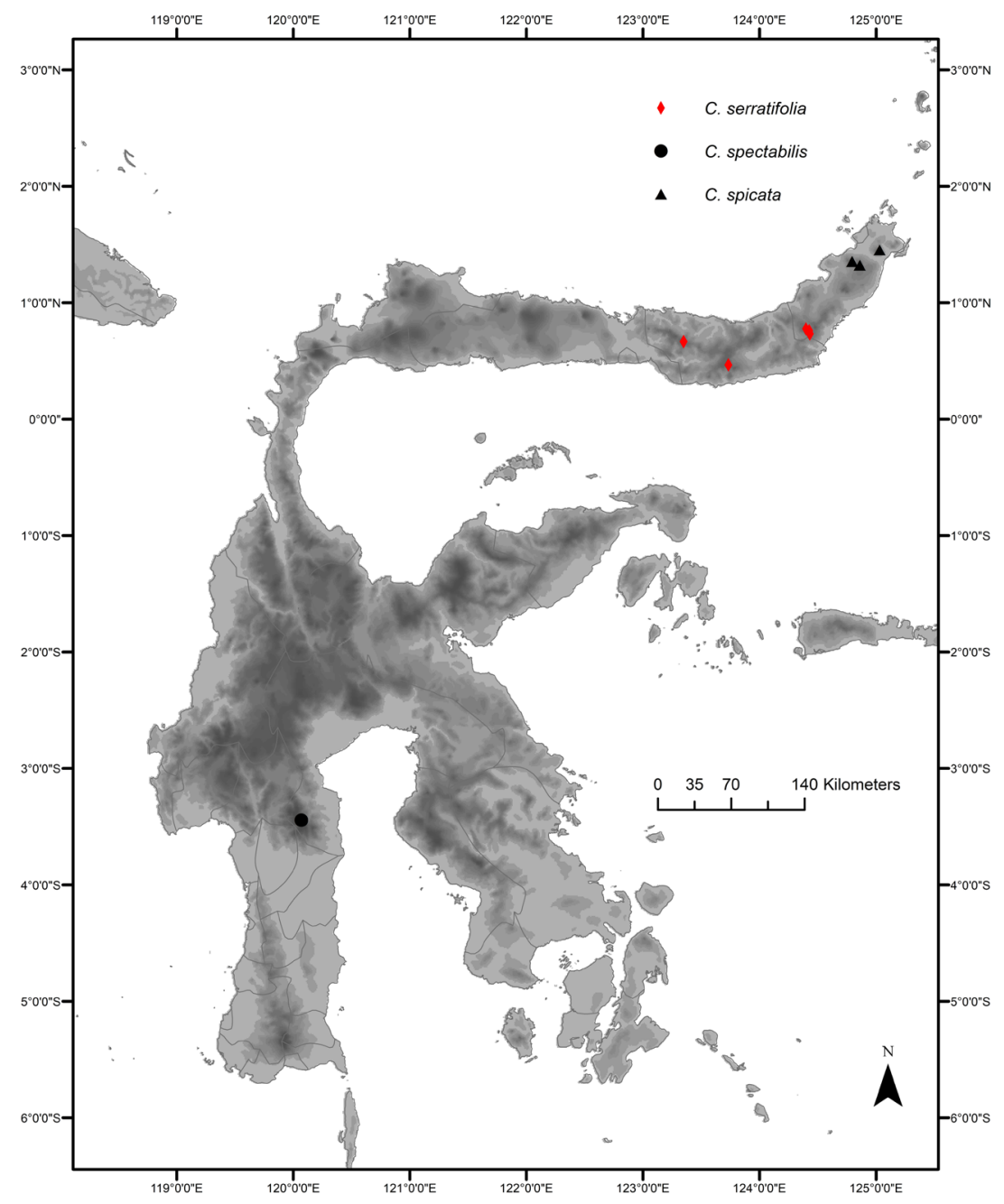

Figure 55. Distribution of Cyrtandra serratifolia (red diamonds), C. spectabilis (black circle) and C. spicata (black triangles).

Habitat and ecology. Upland forest at an altitude of 1100-1500 m.

Etymology. This species is named after its unusual spicate inflorescence (de Vriese, 1856). Proposed IUCN conservation category. This species has an EOO of $88 \mathrm{~km}^{2}$ and an AOO of $12 \mathrm{~km}^{2}$, based on $2 \times 2 \mathrm{~km}$ grid cell size, under the B criteria (Bachman et al., 2011). There are no protected areas in its distribution range (UNEP-WCMC \& IUCN, 2019), which is close to one of the most populated areas of Sulawesi, where threats from intensive agriculture and urban expansion are known (Cannon et al., 2007); the number of collections is low and there are no collections more recent than 1895 , despite relatively frequent fieldwork in North 
Sulawesi. It is therefore suggested that Cyrtandra spicata is considered Endangered (EN), B1ab(iii) + 2ab(iii)

Additional specimens examined. INDONESIA. North Sulawesi. Minahasa: Mt Masarang, Koleskai, $10 \mathrm{i}$ 1895, Koorders $17197 \beta$ (BO, L); Tomohon: Mt Lokon, 7 i 1895, Koorders $17203 \beta$ (BO, L).

This species, with its pendulous narrow inflorescence, is very distinctive, and most similar to the widespread Cyrtandra celebica, with its cauliflorous, but more open and branching, inflorescence. Cyrtandra spicata can most easily be distinguished vegetatively from that species by leaf shape and venation, with the leaves of $C$. spicata being oblanceolate with decurrent leaf bases and 7-10 pairs of lateral veins and those of $C$. celebica being ovate, not decurrent, and with up to 25 lateral vein pairs.

The description for Cyrtandra spicata is brief because the material available is incomplete; it has been compiled to a large extent from de Vriese's original description and illustration, and examination of a single damaged flower. In all specimens seen, the inflorescences have become detached, but it appears from the original illustration as if they are pendulous from the branches.

Reinwardt's collection dated November 1821, bearing the description 'in sylvis montis Klabat' and annotated with the manuscript name Rhynocarpus spicatus, is selected here as the lectotype. Koorders $17197 \beta$ and $17203 \beta$ have both been annotated with the herbarium name of 'Cyrtandra cauliflora Koord., sp.nov.' but were later determined by Koorders as C. spicata de Vriese. Koorders never published the name Cyrtandra cauliflora, and Merrill uses it later for an unrelated Philippine species (Merrill, 1920).

37. Cyrtandra sulcata Blume, Bijdr. Fl. Ned. Ind. 14: 770 (1826) - Type: Indonesia, Java, Blume 221 (lectotype L [L2826829], designated here).

Shrub (height not recorded). Stems striate, somewhat grooved, densely hairy on young growth, almost glabrous on older growth. Leaves opposite, both members of a pair well developed but somewhat unequal in size; petiole very variable, 7-70 mm long, hairy; blades 14-30 × 4-10 cm, narrow oblong to oblanceolate, base acute, slightly asymmetrical, margin serrulate to serrate, apex acuminate; 9-14 pairs of lateral veins and reticulate tertiary venation, sparsely hairy above and below, more densely so on midrib and veins. Inflorescences axillary, subsessile, with up to 6 flowers at various stages of development; bracts narrow ovate, 6-7 × 3-5 mm, densely hairy; peduncles 3-4 mm long, sparsely hairy. Calyx c. $10 \mathrm{~mm}$ long, two lower lobes c. $5.5 \mathrm{~mm}$ long, long-acuminate, three upper lobes slightly shorter, long-acuminate, c. $4.5 \mathrm{~mm}$ long, densely hairy externally. Corolla white, slightly purplish in bud, c. $14 \mathrm{~mm}$ long, more or less parallel-sided, widening very gradually to mouth, mouth oblique, lower lip somewhat extended, hairy externally and with glandular hairs internally on lobes and mouth. Stamens with filaments c. $3.5 \mathrm{~mm}$ long, attached c. $8 \mathrm{~mm}$ from base of corolla, glabrous; anthers $1 \mathrm{~mm}$ long, glabrous; staminodes not seen 
as corolla damaged. Gynoecium c.7 mm long; disc unilateral with very slightly lobed margin, c. $1.5 \mathrm{~mm}$ long, glabrous; ovary and style densely hairy; stigma slightly bilobed, c. $1.5 \mathrm{~mm}$ across. Fruits ovoid, drying dark brown, hairy, particularly towards base of persistent style, verrucose, 5-10 × 3-4 mm, base of style and calyx persistent.

Distribution. South Sulawesi (see Figure 58).

Habitat and ecology. Lowland, hill and upland forest at an altitude of 50-1400 m.

Etymology. This species is named for its grooved stem and branches (Blume, 1826).

Proposed IUCN conservation category. Cyrtandra sulcata is recorded from Sulawesi, Java (Bakhuizen van den Brink, 1950) and Sumatra (fide Bakhuizen van den Brink, K, L) and appears to be one of the most widespread Cyrtandra species in the region. The collections from Sulawesi, however, are from the densely populated area around Makassar at relatively low altitude, and primarily from lowland and hill forest, which are the most threatened habitats on the island (Cannon et al., 2007), and outside any protected areas (UNEP-WCMC \& IUCN, 2019). No collections have been made of this species since 1976, despite this area being very accessible. Research on the distribution and the threats to the subpopulations in Java and Sumatra is needed to understand the species' conservation needs. Cyrtandra sulcata is therefore assessed as Data Deficient (DD). On Sulawesi it is likely that the species is threatened, and conservation actions need to be put in place to conserve the species on this island.

Additional specimens examined. INDONESIA. South Sulawesi. Gowa: Lombasang, 25 iv 1921, Bünnemeijer 11164 (BO, L); ibid., 29 iv 1921, Bünnemeijer 11233 (BO); ibid., 25 v 1921, Bünnemeijer 11734 (BO, L); Mt Bonthain (Mt Lompobatang), 28 v 1921, Bünnemeijer 11766 (BO, L); ibid., 1 vii 1921, Bünnemeijer 12608 (BO); Maros: Bantimurung, 20 ii 1938, Buwalda 3798 (BO, K, L); NE of Makassar, within 54-60 km on the road, 5 vii 1976, Meijer 10881 (A, BO, L, MO); Camba, Teijsmann 12641 (BO).

This species is similar to Cyrtandra longirostris from North Sulawesi in being a shrub with subequal leaves and axillary inflorescences with small white flowers, ovoid fruits and narrow inflorescence bracts but can be most easily distinguished from that species by its much shorter peduncles (3-4 mm long versus $15-40 \mathrm{~mm}$ long) as well as its densely hairy, as opposed to glabrous, ovary and unilateral, as opposed to cupular, nectary disc.

Cyrtandra sulcata was first described by Blume from Java and has a distribution that includes Sumatra (fide Bakhuizen van den Brink, L) and now Sulawesi. The description here is based on the Sulawesi collections only. The Sulawesi material shows the key diagnostic characters of non-decurrent leaf bases, unilateral disc and densely hairy ovary (Bakhuizen van den Brink, 1950).

Blume did not designate a type when he described this species. Therefore, a Blume collection from Java, listed by Clarke (1883) alongside a number of other collections under this species, is selected here as the lectotype. 
38. Cyrtandra tenuicarpa H.J.Atkins, Edinburgh J. Bot. 60(3): 316 (2004). - Type: Indonesia, Sulawesi, Road between Palopo and Rantepao, 3 iii 2000, Mendum et al. 00229 (holotype BO, isotype E). Figure 56.

Branching herb to $1.2 \mathrm{~m}$ in height. Stems striate, sparsely hairy, more densely so when young. Leaves opposite, both in each pair well developed but somewhat unequal; petiole 4-8 mm long, hairy; blades (6-)8-14 × 3-6 cm, elliptic, base acute and strongly asymmetrical, margin subentire to minutely serrulate, apex acuminate; 10-12 pairs of lateral veins curving upwards, sparsely hairy above and below, more densely so on midrib and veins. Inflorescences axillary, pedunculate and pendulous, 3- to 5-flowered; bracts 1-2 mm long, ovate, hairy to densely hairy; peduncles 35-80 mm long, sparsely hairy, slender (c.0.5 mm in diameter); pedicels 7-15(-30) $\mathrm{mm}$ long. Calyx pale green, 4-5 mm long, slightly bilabiate, 5-lobed, lobes triangular, acuminate, 2-3 $\mathrm{mm}$ long, sparsely hairy externally. Corolla white, 15-16 mm long, narrow below, widening to mouth apically, lower lobe larger than others c. $5 \times 3 \mathrm{~mm}$, other lobes smaller, somewhat recurved, c. $2 \times 2 \mathrm{~mm}$, glandular hairy externally. Stamens with filaments $4-5 \mathrm{~mm}$ long, attached c. $10 \mathrm{~mm}$ from base of corolla; anthers c. $1 \mathrm{~mm}$ long, not cohering at apices before dehiscence; staminodes 3 , less than c. $1.5 \mathrm{~mm}$ long. Gynoecium 14-15 mm long; disc cupular, undulate, $1 \mathrm{~mm}$ long, glabrous; ovary and style glandular hairy; stigma bilobed, lobes vertical and pressed together, oblong, c. $1 \mathrm{~mm}$ long. Fruits narrowly cylindrical, 25-35 × 1.5-2 mm, green when young, glabrous except for glandular hairs on persistent style, calyx sometimes persistent.

Distribution. Central, West and South Sulawesi (see Figure 58).

Habitat and ecology. Upland and montane forest at an altitude of 800-1642 m.

Etymology. This species is named for its distinctive, narrow fruits (Atkins, 2004).

Proposed IUCN conservation category. The EOO of this species is $314 \mathrm{~km}^{2}$ and the AOO is $12 \mathrm{~km}^{2}$, based on a $2 \times 2 \mathrm{~km}$ grid cell size (Bachman et al., 2011). It has not been possible to trace the exact locality of Rachmat 573 (BO), so the EOO and AOO are based on three of the four known collections. Satellite imagery shows habitat degradation and land conversion in the georeferenced collection localities, and the species has not been recorded from any protected areas (UNEP-WCMC \& IUCN, 2019). Cyrtandra tenuicarpa is therefore assessed as Endangered (EN), B1ab(iii) + 2ab(iii).

Additional specimens examined. INDONESIA. West Sulawesi. Mamasa: Mt Gandang Dewata, 20 iv 2016, Kartonegoro, Ardiyani, Santoso \& Wulansari ARK 902 (BO, E).

South Sulawesi. North Luwu: Tojambu, 800 m, 20 vi 1929, Kjellberg 1686 (BO, S).

Sulawesi. Mt Timbaang, 1913, Rachmat 573 (BO).

Cyrtandra tenuicarpa is distinctive in Sulawesi, and identified most easily by its very narrow fruits. This is a character much more commonly seen in Borneo, in species such as Cyrtandra bullifolia B.L.Burtt., C. dallasensis B.L.Burtt and C. elmeri Merr. 


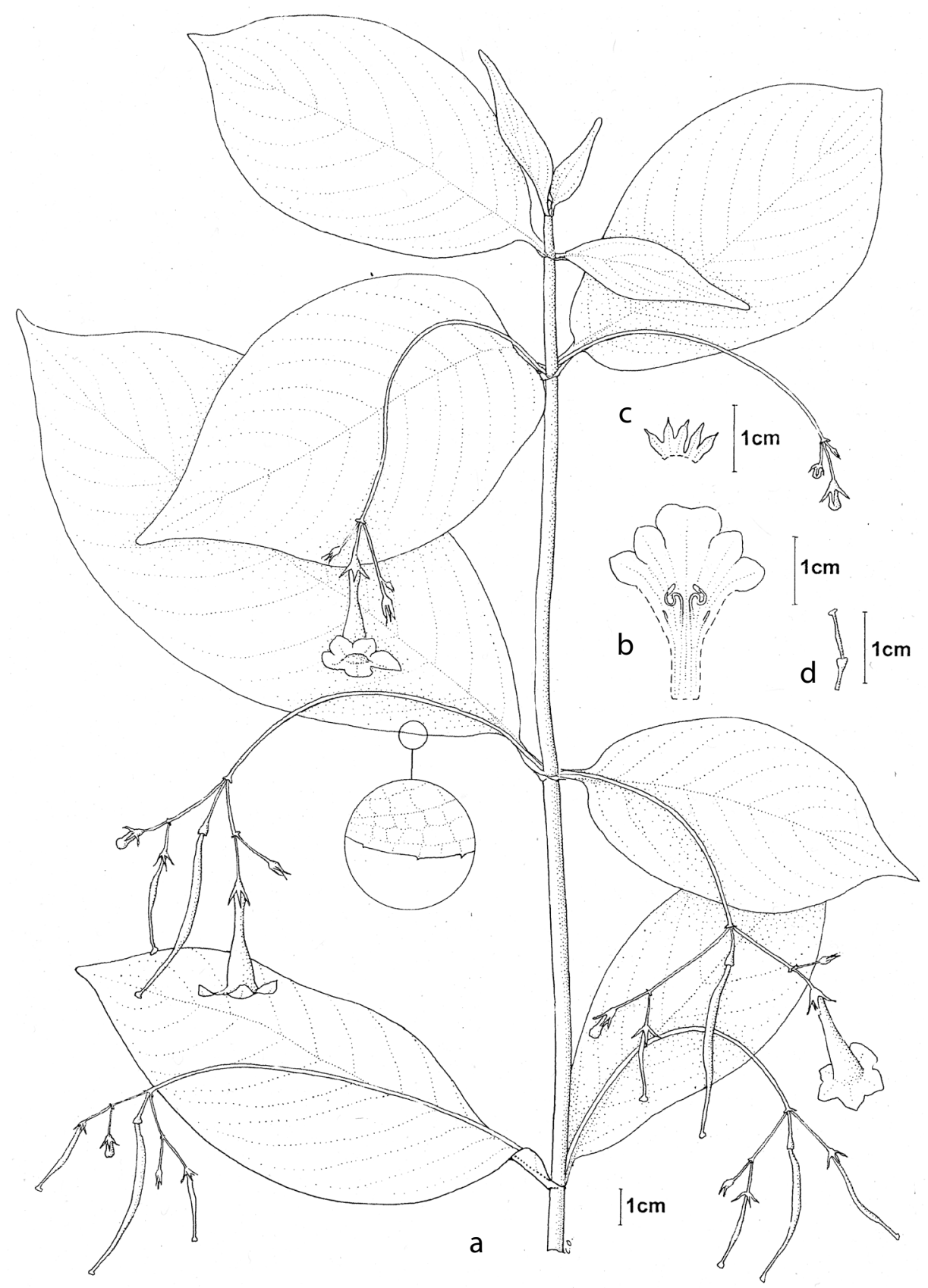

Figure 56. Cyrtandra tenuicarpa. a, Habit; b, opened corolla, showing position of stamens and staminodes; c, opened calyx, showing inner surface; $d$, gynoecium including disc. Drawn by Christina Oliver from Mendum et al. 00229. Reproduced from Atkins (2004) with the permission of the Trustees of the Royal Botanic Garden Edinburgh. 
A note on the Kartonegoro et al. ARK902 collection from West Sulawesi states that it is used as a medicine to treat fever.

39. Cyrtandra widjajae Karton., Reinwardtia 14(1): 6 (2014). - Type: Indonesia, Sulawesi, Southeast Sulawesi, North Kolaka, Mekongga Mts, Rante Angin District, Tinukari Village, 28 xi 2010, Widjaja et al. 9412 (holotype BO; isotypes DAV, E). Figure 57.

Shrub to $2 \mathrm{~m}$ in height. Stems striate, sparsely hairy. Leaves opposite; one leaf of a pair markedly reduced; petiole 5-10 mm long, glabrous to sparsely hairy; blades of larger leaves 7-16 $\times 2-4 \mathrm{~cm}$, narrow oblong to oblanceolate, base acute, slightly asymmetrical, margin subentire, apex long-acuminate; 8-14 pairs of lateral veins, curving upwards and running out to margin, subglabrous above, sparsely hairy below, more densely so on midrib and veins. Reduced leaves 5-10 × 5-7 mm, ovate to cordate, resembling the larger leaves in other respects. Inflorescences axillary, sessile, 1-4(-7)-flowered; bracts 2-4 × 0.5-1 mm, linear-lanceolate, hairy; pedicels $2-4 \mathrm{~mm}$ long, sparsely to densely hairy. Calyx narrow campanulate, white to pale green, 6-10 mm long, more or less evenly 5-lobed to slightly bilabiate with three upper lobes united into a shallowly triangular lip and two lower lobes mostly free, lobes linear, 3-7 mm long, sparsely hairy externally. Corolla white, $12-15 \mathrm{~mm}$

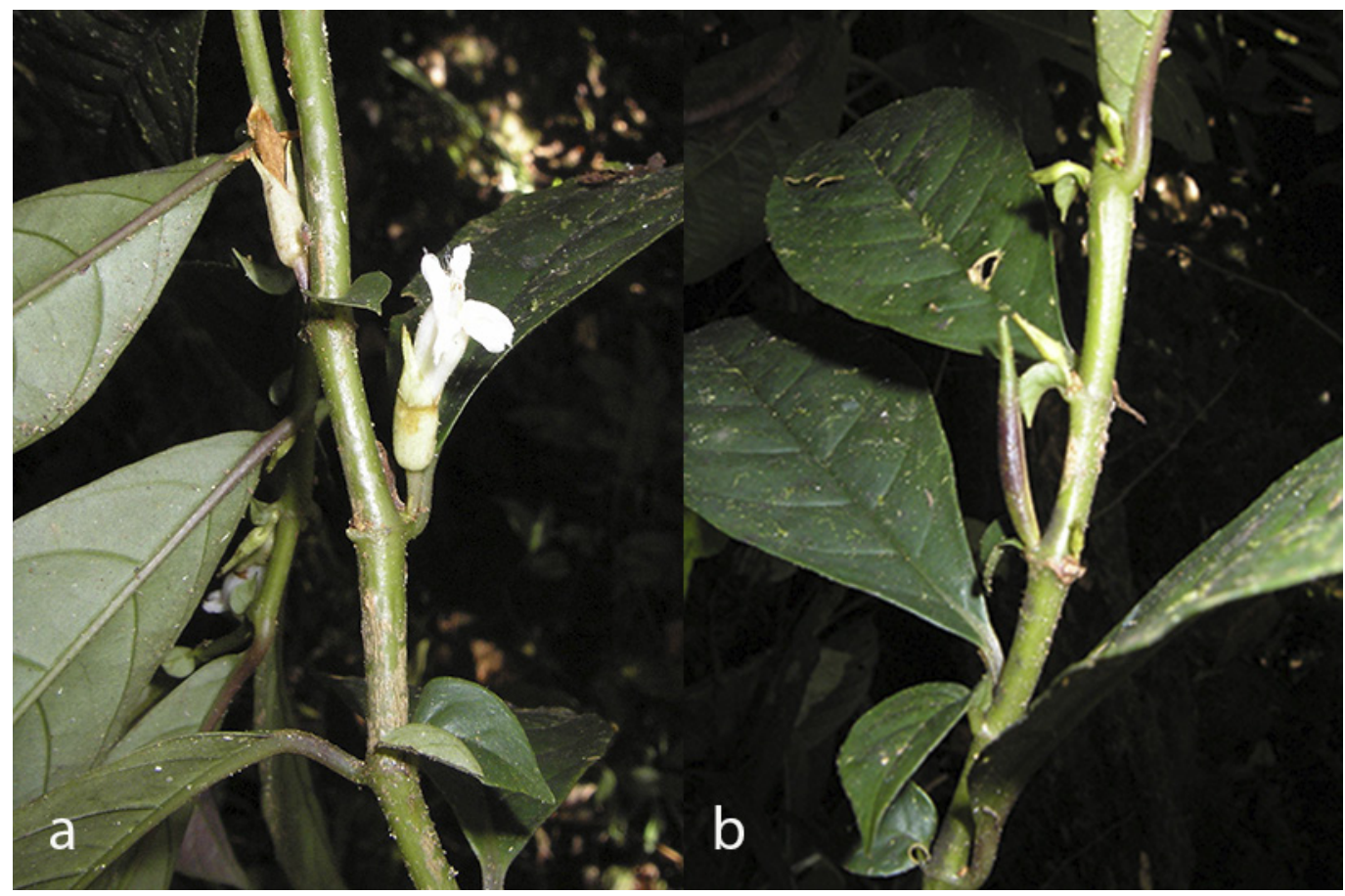

Figure 57. Cyrtandra widjajae. a, Side view of corolla; b, fruit. Photographs: D. Girmansyah. Specimen: Widjaja et al. 9412. 
long, tube narrow in basal half, gradually widening to mouth in upper half, upper lobes 2-4 $\times 1-2 \mathrm{~mm}$, lower and lateral lobes $3-5 \times 1-2 \mathrm{~mm}$, hairy externally, glandular hairy internally on the lobes, particularly towards the base and inside tube below the anthers. Stamens with filaments 3-5 mm long, attached 5-6 $\mathrm{mm}$ above base of corolla, glabrous; anthers 1-1.5 mm long, cohering at apices before dehiscence; staminodes very reduced, less than $1 \mathrm{~mm}$ long. Gynoecium 6-9 mm long; disc cupular with lobed margin, $1 \mathrm{~mm}$ long, glabrous externally; ovary densely eglandular hairy; style densely eglandular hairy becoming glandular towards stigma; stigma bilobed, $1-1.5 \mathrm{~mm}$ across. Fruits $8-13(-30) \times 2-3(-5) \mathrm{mm}$, oblong and often curved, densely hairy, calyx not or only partially persistent, base of style persistent. Distribution. North, Central and Southeast Sulawesi (Figure 58).

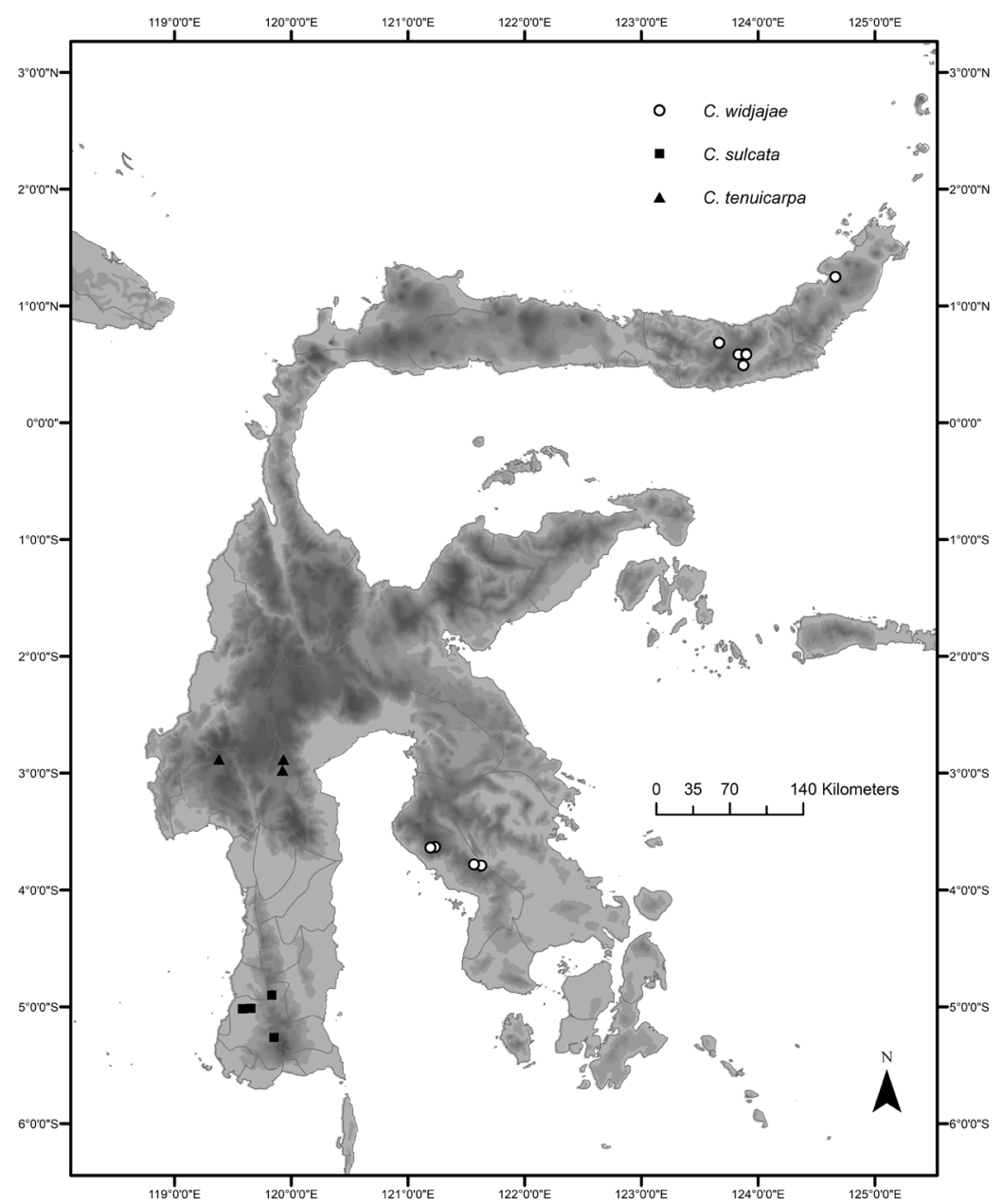

Figure 58. Distribution of Cyrtandra sulcata (black squares), C. tenuicarpa (black triangles) and C. widjajae (white circles). 
Habitat and ecology. Lowland, hill and upland forest at an altitude of 300-1100 m.

Etymology. This species is named after Elizabeth A. Widjaja (BO), bamboo taxonomist and one of the collectors of the type of this species (Kartonegoro \& Potter, 2014).

Proposed IUCN conservation category. The EOO of Cyrtandra widjajae is $102,193 \mathrm{~km}^{2}$ and the AOO is $44 \mathrm{~km}^{2}$, based on a $2 \times 2 \mathrm{~km}$ grid cell size (Bachman et al., 2011). Some of the collection localities in the northern area of its distribution fall within the limits of the Bogani Nani Wartabone National Park, and the Central Sulawesi collection localities fall within Lore Lindu National Park (UNEP-WCMC \& IUCN, 2019), therefore their populations should have some degree of protection. However, none of the southern populations from which collections were made are protected, and most of the collections are from the more threatened lowland and hill forest areas (Cannon et al., 2007). A category of Least Concern (LC) is given for this species.

Additional specimens examined. INDONESIA. North Sulawesi. Bolaang Mongondow: Mount London, near Tunpa river, 31 xi 2016, Barber, Atkins, Kartonegoro \& Kinho BAKK32 (BO, E); Bogani Nani Wartabone National Park, 5 i 1996, Kato et al. 355 (L); Dumoga Bone National Park, Edwards Camp, 7 iii 1985, de Vogel \& Vermuelen 6779 (E, L); Dumoga Bone National Park, Waterfalls Trail, 1 iv 1985, de Vogel \& Vermeulen 6829 (E, K, L); Minahasa: 220 km W of Menado, 7 iii 1990, Burley et al. 3697 (A, CANB, K, L, SING); Pinamorongan, 30 i 1895, Koorders 17192 (BO, L); South Minahasa: Mt Lolombulan, 9 iv 1895, Koorders $17202 \beta$ (BO).

Southeast Sulawesi. Kolaka: Mount Watuwila, along Uwitalambeh River, near Mount Pobindaa Omanu, west of Wutamole, 17 v 2008, Girmansyah 941 (BO, L); ibid., Tawanga, 25 iii 1929, Kjellberg 983 (BO); Upper Silui and Poraboa villages, 14 v 2008, Wiriadinata HW13311 (BO); North Kolaka: Along the trail to Mount Mekongga, 19 iii 2006, Girmansyah 596 (BO); Rante Angin subdistrict, Tinukari village, 1 vii 2011, Widjaja et al. EAW9727 (BO, E).

Cyrtandra aff. widjajae

Central Sulawesi. Sigi: Lore Lindu National Park, Sopu Valley, c.80 km SSE of Palu, 27 iv 1979, van Balgooy 3037 (A, L); Lore Lindu National Park, Sopu Valley, c.80 km S of Palu., 29 iv 1979, Hennipman 5111 (A, E, L, NSW); Lore Lindu National Park, Sopu Valley, 29 v 1979, Hennipman 5684 (A, L); Lore Lindu National Park, Sopu Valley, end of logging road, 1 v 1979, de Joncheere 1134 (E, L); Lore Lindu National Park, Sopu Valley, trail to Puncak Dingin, 14 v 1979, de Joncheere 1281 (L); Lore Lindu National Park, Sopu Valley, c.80 km SSE of Palu, 9 iv 1979, de Vogel 5097 (L, NSW); Mt Roroka Timbu, w. slope, 11 v 1979, de Vogel 5278 (BO, L, NSW).

Cyrtandra widjajae is part of the group of six species that share the characters of strongly anisophyllous leaves; white or light-yellow corollas; and densely hairy calyces, corollas and fruits. The others in the group are Cyrtandra balgooyi, C. engleri, C. gambutensis, C. gorontaloensis and C. parvicalyx.

The species was first described from the under-collected Mekkongga region of Southeast Sulawesi (Kartonegoro \& Potter, 2014). Included here under Cyrtandra widjajae are a group of specimens from Minahasa and Bolaang Mongondonow in North Sulawesi. These 
collections were originally given the herbarium name 'Cyrtandra minahassae' by Koorders, and this name was included in a list of Cyrtandra species present on the island, but a description was never provided (Koorders, 1898).

The two disjunct sets of collections, from the north and the southeast, differ slightly in calyx shape (the collections from the north having more evenly 5-lobed calyces) and in fruit length, although this character can vary significantly on stage of maturity. In addition to these two disjunct groups there are number of additional collections from the Lore Lindu area of Central Sulawesi, which differ in having more linear, scale-like reduced leaves (as opposed to cordate leaves), slightly smaller flowers and longer inflorescence bracts.

Further collections from throughout its distribution, but particularly from Central Sulawesi, are required to clarify the limits of Cyrtandra widjajae and the extent of variation. Further collections may necessitate separation of these populations into different taxa, but for now and based on the material available, they are kept together.

\section{Acknowledgements}

We would like to thank the curators of the following herbaria for loan of material or access to their collections: A, BM, BO, CANB, E, K, KRB, L, NSW, S and WU. We are grateful to Christina Oliver and Claire Banks for their excellent illustrations; to Deden Girmansyah, Wisnu Ardi, Fabian Brambach, Steve Scott and Sadie Barber for permission to include their photographs; and to Steve Scott, Sadie Barber, Nathan Kelso and Stephen Willis for taking excellent care of the living collections of Cyrtandra at RBGE. We would also like to thank the staff of the Kebun Raya Bogor and Herbarium Bogoriense for their assistance in the field, especially Hendrian and Sofyan from the Kebun Raya, and also Julianus Kinho from the Menado Institute of Forestry. We would like to thank the following for general advice and comments on the manuscript: Sandy Atkins, Gemma Bramley, Mark Coode, David Middleton, Mark Hughes, Michael Kiehn and Peter Wilkie. Finally, we would like to thank the Edinburgh Botanic Garden (Sibbald) Trust, the Singapore Botanic Garden Fellowship, and the players of the People's Postcode Lottery for funding aspects of this research.

The Royal Botanic Garden Edinburgh is supported by the Rural and Environment Science and Analytical Services Division (RESAS) of the Scottish Government.

\section{References}

Atkins HJ. 2004. The Gesneriacae of Sulawesi II: seven new species of Cyrtandra. Edinburgh Journal of Botany 60(3):305-321.

Atkins HJ, Bramley GLC, Clark JR. 2013. The taxonomy of Cyrtandra (Gesneriaceae): current knowledge, future directions. Selbyana 31(2):157-165.

Atkins HJ, Bramley GLC, Johnson MA, Kartonegoro A, Nishii K, Kokubugata G, Möller M, Hughes M. 2020. A molecular phylogeny of Southeast Asian Cyrtandra (Gesneriaceae) supports an emerging paradigm for Malesian plant biogeography. Frontiers of Biogeography 2(1):e44814. 
Bachman S, Moat J, Hill AW, de la Torre J, Scott B. 2011. Supporting Red List threat assessments with GeoCAT: Geospatial Conservation Assessment Tool. In: Smith V, Penev L, editors. E-Infrastructures for Data Publishing in Biodiversity Science. Zookeys. 150:117-126 (version BETA).

Bakhuizen van den Brink RC. 1950. Notes on the Flora of Java. VI. Blumea. 6:363-406.

Blume CL. 1826. Bijdragen tot de flora van Nederlandisch Indie. Vol. 140. Jakarta: Lands Drukkerij.

Bone RE, Atkins HJ. 2013. Four new species of Cyrtandra (Gesneriaceae) from the Latimojong Mountains, South Sulawesi. Edinburgh Journal of Botany 70(3):455-468.

Bramley GLC. 2003. Local, regional and monographic approaches to Cyrtandra (Gesneriaceae). Ph.D. thesis, University of Edinburgh.

Bramley GLC, Weber A, Cronk QCB, Bokhari MH. 2003. The genus Cyrtandra (Gesneriaceae) in Peninsular Malaysia and Singapore. Edinburgh Journal of Botany. 60(3):331-360.

Bridson D, Forman L. 1999. The Herbarium Handbook, 3rd edition. Richmond: Royal Botanic Gardens, Kew.

Burtt BL. 1990. Gesneriaceae of the Old World. I. New and little-known species of Cyrtandra from Malesia. Edinburgh Journal of Botany 47:201-233.

Burtt BL. 2001. A survey of the genus Cyrtandra (Gesneriaceae). Phytomorphology. Golden Jubilee Issue:393-404.

Cannon $\mathrm{CH}$, Summers M, Harting JR, Kessler PJ. 2007. Developing conservation priorities based on forest type, condition, and threats in a poorly known ecoregion: Sulawesi, Indonesia. Biotropica 39(6):747-759.

Clark JR, Atkins HJ, Bramley GLC, Jolles DD, Roalson E, Wagner W. 2013. Towards a phylogenetically informed taxonomy of Cyrtandra (Gesneriaceae) in the Solomon Islands. Selbyana 31(2):393-404.

Clarke CB. 1883. Cyrtandreae (Gesneracearum tribus). In: Candolle A de, Candolle C de, editors. Monographiae Phanerogamarum, vol. 5, part 1. Paris: G. Masson. pp. 1-303.

Elmer ADE. 1910. New and interesting Gesneriaceae. Leaflets of Philippine Botany. 3:956-970.

Evans BJ, Supriatna J, Andayani N, Setiadi MI, Cannatella DC, Melnick DJ. 2003. Monkeys and toads define areas of endemism on Sulawesi. Evolution 57(6):1436-1443.

Frodin D. 2001. Floras in retrospect and for the future. Plant Talk 25:36-39.

Gower DJ, Johnson KG, Richardson JE, Rosen BR, Ruber L, Williams ST. 2012. Introduction. In: Gower DJ, Johnson KG, Richardson JE, Rosen BR, Ruber L, Williams ST, editors. Biotic evolution and environmental change in southeast Asia. Systematics Association Special Volume Series. Cambridge, UK: Cambridge University Press, pp. 1-15.

Hall R. 2002. Cenozoic geological and plate tectonic evolution of SE Asia and the SW Pacific: computer-based reconstructions, model and animations. Journal of Asian Earth Science. 20(4):353-431.

Hall R. 2012. Sundaland and Wallacea: geology, plate tectonics and palaeogeography. In: Gower DJ, Johnson KG, Richardson JE, Rosen BR, Ruber L, Williams ST, editors. Biotic evolution and environmental change in Southeast Asia. Systematics Association. Special Volume Series. Cambridge: Cambridge University Press, pp. 32-78. 
Hickey LJ. 1979. A revised classification of the architecture of dicotyledonous leaves. In: Metcalfe CR, Chalk L, editors. Anatomy of the Dicotyledons. Oxford: Clarendon Press. pp. 25-39

Hilliard OM, Burtt BL. 2002. The genus Agalmyla (Gesneriaceae-Cyrtandroideae). Edinburgh Journal of Botany. 59(1):1-210.

IUCN. 2012. IUCN Red List Categories and Criteria, version 3.1, 2nd edition. Gland, Switzerland, and Cambridge: International Union for Conservation of Nature.

Johnson MA, Clark JR, Wagner WL, McDade LA. 2017. A molecular phylogeny of the Pacific clade of Cyrtandra (Gesneriaceae) reveals a Fijian origin, recent diversification, and the importance of founder events. Molecular Phylogenetics and Evolution 116:30-48.

Kartonegoro A, Potter D. 2014. The Gesneriaceae of Sulawesi VI: the species from Mekongga Mts. with a new species of Cyrtandra described. Reinwardtia 14(1):1-11.

Kartonegoro A, Bone RE, Atkins HJ. 2018. Eleven new species of Cyrtandra (Gesneriaceae) from Sulawesi, Indonesia. Edinburgh Journal of Botany. 75(2):173-204.

Kessler PJA, Bos MN, Sierra Daza SEC, Kop A, Willemse LPM, Pitopang R, Gradstein SR. 2002. Checklist of the woody plants of Sulawesi, Indonesia. Blumea Suppl. 14:1-160

Koorders SH. 1898. Verslag eener botanische dienstreis door de Minahasa. Mededeelingen uit's Lands Plantentuin 19:i-xvii, 1-716.

Kraenzlin F. 1906. Cyrtandraceae Malayanae insularis novae. Journal of Linnaean Society. 37:275-285.

Kraenzlin F. 1913. Cyrtandraceae novae Philippinenses II. Philippine Journal of Science. 8(5):311-333.

Lohman DJ, de Bruyn M, Page T, von Rintelen K, Hall R, Ng PK, Shih HT, Carvalho GR, Von Rintelen T. 2011. Biogeography of the Indo-Australian archipelago. Annual Review of Ecology Evolution and Systematics. 42:205-226.

McDade L. 1995. Species concepts and problems in practice: insight from botanical monographs. Systematic Botany. 20(4):606-622.

Mendum M, Atkins HJ. 2004. The Gesneriaceae of Sulawesi I: an introduction. Edinburgh Journal of Botany. 60(3):299-304.

Merrill ED. 1920. New or noteworthy Philippine plants XVI. Philippine Journal of Science 17(3):239-323.

Middleton DJ. 2009. A revision of Aeschynanthus (Gesneriaceae) in Cambodia, Laso and Vietnam. Edinburgh Journal of Botany. 66(3):391-446.

Middleton DJ, Armstrong K, Baba Y, Balslev H, Chayamarit K, Chung RCK, Conn BJ, Fernando ES, Fujikawa K, Kiew R, Luu HT. 2019. Progress on Southeast Asia's Flora projects. Gardens Bulletin of Singapore. 71(2):267-319.

Nugraha AMS, Hall R. 2018. Late Cenozoic palaeogeography of Sulawesi, Indonesia. Palaeogeography, Palaeoclimatology, Palaeoecology. 490:191-209.

Olivar JEC, Muellner-Riehl A. 2019. Replacement names for Cyrtandra humilis Elmer and Cyrtandra umbellata Kraenzl., two endemic Philippine species (Gesneriaceae). Phytotaxa. 418(1):117-118.

Olivar JEC, Atkins H, Hauenschild F, Muellner-Riehl AN. 2020. Cyrtandra argentii, a new species of Cyrtandra (Gesneriaceae) from the Philippines, and a review of the $C$. villosissima group. European Journal of Taxonomy. 676. https://doi.org/10.5852/ejt.2020.676 
Poulsen AD. 2012. Etlingera of Sulawesi. Kota Kinabalu: Natural History Publications (Borneo).

Schlechter R. 1923. Gesneriaceae Papuanae. Botanische Jahrbücher für Systematik 58:255-379.

Thiers B. Continuously updated. Index Herbariorum: A Global Directory of Public Herbaria and Associated Staff. New York Botanical Garden's Virtual Herbarium. http://sweetgum.nybg.org/ science/ih/ [Accessed 10 March 2020.]

Thomas DC, Ardi WH, Hughes M. 2011. Nine new species of Begonia (Begoniaceae) from South and West Sulawesi, Indonesia. Edinburgh Journal of Botany 68(2):225-255.

Trethowan LA, Eiserhardt WL, Girmansyah D, Kintamani E, Utteridge TM, Brearley FQ. 2020. Floristics of forests across low nutrient soils in Sulawesi, Indonesia. Biotropica 52(6):1309-1318.

Turland NJ, Wiersema JH, Barrie FR, Greuter W, Hawksworth DL, Herendeen P, Knapp S, Kusber W-H, Li D-Z, Marhold K, May TW, McNeill J, Monro AM, Prado J, Price MJ, Smith GF, editors. 2018. International Code of Nomenclature for algae, fungi, and plants (Shenzhen Code) Adopted by the Nineteenth International Botanical Congress Shenzhen, China, July 2017. Regnum Vegetabile 159. Glashütten: Koeltz Botanical Books.

UNEP-WCMC, IUCN. 2019. Protected Planet: the World Database on Protected Areas (WDPA).

Cambridge: UNEP-WCMC and IUCN. https://www.protectedplanet.net [Accessed 1 November 2019.]

Van Balgooy MMJ. 1971. Plant geography of the Pacific. Blumea Suppl. 6:1-220.

Van der Ent AJ, Baker AJ, van Balgooy MMJ, Tjoa A. 2013. Ultramafic nickel laterites in Indonesia

(Sulawesi, Halmahera): mining, nickel hyperaccumulators and opportunities for phytomining. Journal of Geochemical Exploration. 128:72-79.

Van Steenis CGGJ, editor. 1950. Flora Malesiana, Series 1, vol. 1. Jakarta: Noordhoff-Kolff.

Vriese WH de. 1856. Plantae Indiae Batavae Orientalis. Leiden: E. J. Brill.

\section{Index of exsiccatae}

In the following index, the names of accepted taxa are given in roman font and those of synonyms in italics. The number after the decimal point in parentheses refers to the species number in the main text.

Cyrtandra (1)

Cyrtandra albiflora Karton. \& H.J.Atkins (1.1)

Cyrtandra balgooyi H.J.Atkins \& Karton. (1.2)

Cyrtandra boliohutensis Karton. \& H.J.Atkins (1.3)

Cyrtandra bruteliana Koord. (1.4)

Cyrtandra celebica Blume (1.5)

Cyrtandra coccinea var. celebica (Blume) C.B.Clarke (1.5)

Cyrtandra engleri Koord. (1.6)

Cyrtandra fasciata H.J.Atkins (1.7)

Cyrtandra flavomaculata H.J.Atkins \& Karton. (1.8)

Cyrtandra floccosa R.Bone \& H.J.Atkins (1.9)

Cyrtandra gambutensis Karton. \& H.J.Atkins (1.10)

Cyrtandra geocarpa Koord. (1.11) 
Cyrtandra gorontaloensis H.J.Atkins (1.12)

Cyrtandra hekensis Karton. \& H.J.Atkins (1.13)

Cyrtandra hendrianii Karton. \& H.J.Atkins (1.14)

Cyrtandra hispidula Karton. \& H.J.Atkins (1.15)

Cyrtandra hypogaea Koord. (1.16)

Cyrtandra jellesmanii Koord. (1.17)

Cyrtandra kinhoi Karton. \& H.J.Atkins (1.18)

Cyrtandra kjellbergii R.Bone \& H.J.Atkins (1.19)

Cyrtandra longirostris de Vriese (1.20)

Cyrtandra longistamina H.J.Atkins \& Karton. (1.21)

Cyrtandra luteiflora H.J.Atkins (1.22)

Cyrtandra mollis de Vriese (1.23)

Cyrtandra multinervis Karton. \& R.Bone (1.24)

Cyrtandra nitida Karton. \& H.J.Atkins (1.25)

Cyrtandra parvicalyx H.J.Atkins \& Karton. (1.26)

Cyrtandra polyneura (C.B.Clarke) B.L.Burtt (1.27)

Cyrtandra purpurea H.J.Atkins (1.28)

Cyrtandra purpureofucata R.Bone \& H.J.Atkins (1.29)

Cyrtandra rantemarioensis Karton. \& R.Bone (1.30)

Cyrtandra roseiflora H.J.Atkins (1.31)

Cyrtandra rubribracteata Karton. \& H.J.Atkins (1.32)

Cyrtandra sandei de Vriese (1.33)

Cyrtandra serratifolia H.J.Atkins (1.34)

Cyrtandra spectabilis R.Bone \& H.J.Atkins (1.35)

Cyrtandra spicata de Vriese (1.36)

Cyrtandra sulcata Blume (1.37)

Cyrtandra tenuicarpa H.J.Atkins (1.38)

Cyrtandra vriesii C.B.Clarke (1.23)

Cyrtandra widjajae Karton. (1.39)

In the following list, the prefixes de and van are not treated as part of the surname.

Afriastini, J.J. 2053 (1.5); Alston, A.H.G. 15665 (1.5), 15859 (1.5), 15926 (1.18), 15952 (1.27), 16129 (1.4), 16189 (1.5), 16223 (1.27), 16280 (1.20), 16576 (1.27); Ambriansyah AA2656 (1.5); Ardi, W.H.

WI164 (1.8), WI209 (1.16), WI211 (1.4), WI212 (1.3), WI220 (1.27), WI222 (1.16), WI224 (1.3), WI225 (1.2), WI229 (1.8), WI230 (1.16), WI248 (1.5), WI277 (1.16), WI288 (1.27), WI291 (1.25), WI296 (1.2), WI299 (1.8), WI300 (1.27), WI345 (1.31), WI393 (1.5), WI398 (1.27), WI406 (1.11); Ardiyani, M. et al. 165 (1.30); Atkins, H. et al. 38 (1.10), 40 (1.27), 52 (1.22), 54 (1.7), 56 (1.18), 91 (1.12), 93 (1.34), 114 (1.27), 139 (1.11), 142 (1.27), 188 (1.3), 190 (1.3), 209 (1.6), 252 (1.11); Atkins, H.J. 10 (1.34), 12 (1.11), 46 (1.16), $58(1.27)$

van Balgooy, M.M.J. 3005 (1.27), 3037 (aff. 1.39), 3124 (1.28), 3434 (1.16), 3442 (cf. 1.7), 3469

(1.2), 3501 (1.16), 3503 (1.28), 3565 (1.8), 3571 (1.8), 3911 (1.27); Barber, S. et al. BAKK7 (1.11), BAKK8 (1.5), BAKK12 (1.5), BAKK15 (1.5), BAKK17 (1.16), BAKK18 (1.27), BAKK25 (1.11), BAKK30

(1.16), BAKK32 (1.39), BAKK36 (1.18), BAKK39 (1.4), BAKK41 (1.27), BAKK42 (1.23), BAKK43

(1.12), BAKK44 (1.34), BAKK49 (1.5), BAKK52 (1.23), BAKK54 (1.34), BAKK65 (1.18), BAKK68 
(1.12), BAKK83 (1.23); Bloembergen, S. 3986 (1.2), 4029 (1.16), 4124 (1); Blume, C.L. 221 (1.37); Boesveld, J. s.n. (1.5); Brambach, F. 04-85 (1.21); Brown, G. et al. 4 (1.30), 82 (1.4), 83 (1.21), 97 (1); Bünnemeijer, H.A.B. 11164 (1.37), 11233 (1.37), 11734 (1.37), 11766 (1.37), 12608 (1.37); Burley, J.S. \& Tukirin et al. 3697 (1.39), 3701 (1.11); Buwalda, P. 3798 (1.37)

Cicuzza, D. 549 (1.3), 620 (1.16), 787 (1.2), 793 (1.16), 936 (1.2), 984 (1), 1016 (1.16); Coode, M.J.E. 5933 (1.27), 5944 (1.5), 5983 (1.16); Cubey, H.S. \& Scott, S.M. 255 (1.34); Culmsee, H. y2077 (1.2) de la Savinierre, E. 138 (1.5)

Eyma, P.J. 467 (1.30), 696 (1.29), 3697 (1.27), 3909 (1.32)

Forman, L.L. 185 (1.6), 223 (1.18), 224 (1.6), 225 (1.5), 342 (1.4), 366 (1.6), 385 (1.5), 393 (1.16), 395

(1.23); Forsten, E.A. 86 (1.27), 157 (1.20)

Girmansyah, D. 580 (1.8), 584 (1.4), 596 (1.39), 883 (1.27), 941 (1.39), 1127 (1.4), 1215 (1.18), 1257

(1.16)

Hendrian, Newman, M.F., Scott, S.M., Saleh, M.N. \& Supriadi, D. 848 (1.1), 883 (1.14), 896 (1.5), 900

(1.16), 901 (1.13), 968 (1.32); Hennipman, E. 5110 (1.2), 5111 (aff. 1.39), 5621 (1.16), 5684 (aff. 1.39), 5939 (1.8), 5994 (1.16); Hicks, D. 87 (1.5), 225 (1.5); Hidayat, A. et al. AH4095 (1.5), AH4217 (1.4); Hose, C. 799 (1.5)

Johansson, J.T. et al. 135 (1.27), 195 (1.16); de Joncheere, G.J. 1134 (aff. 1.39), 1281 (aff. 1.39) Kartonogero, A. ARK239 (1.27); Kartonogero, A. \& Santoso, W. ARK475 (1.30); Kartonogero, A. et al.

ARK902 (1.38), ARK904 (1.16); Kato, M. et al. 355 (1.39); Kaudern, W. 46 (1.17), 59 (1.4), 184 (1.34), 186 (1.6); Kessler, P.J.A. et al. PK2892 (1.28), PK2974 (1.24), PK3060 (1.7); Kjellberg, G.K. 983 (1.39), 1020 (1.4), 1053 (1), 1459 (1.19), 1567 (1), 1686 (1.38), 1749 (1), 2334 (1.16), 2498 (1.16), 2664 (1.16), 2720 (1), 2762 (1), 4039 (1.29), 4040 (1.30), 4046 (1.9); Koorders, S.H. 17109 $(1.27), 17179 \beta$ (1.5), $17180 \beta$ (1.11), $17181 \beta$ (1.23), $17182 \beta$ (1.20), $17183 \beta$ (1.4), $17184 \beta$ (1.5), $17185 \beta$ (1.27),

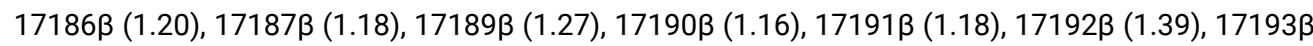

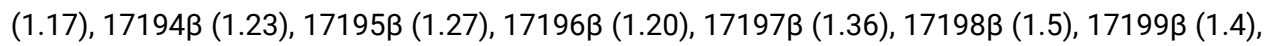
$17200 \beta$ (1.27), $17201 \beta$ (1.5), $17202 \beta$ (1.39), $17203 \beta$ (1.36), $17204 \beta$ (1.6), 19377 (1.11); Kruyff, J.S.A. 17 (1.23), 18 (1.5).

Lam, H.J. 2697 (1.27), 2744 (1.5), 3476 (1).

Meijer, W. 9342 (1.16), 9440 (1), 9451 (1.11), 9585 (1), 9601 (1.11), 9971 (1.11), 9981 (1.5), 10881 (1.37); Mendum, M. et al. 00111 (1.25), 00129 (1.5), 00149 (1.11), 00158 (1.26), 00159 (1), 00160 (1.7), 00173 (1.31), 00196 (1.3), 00197 (1.21), 00198 (1.7), 00217 (1.27), 00220 (1.16), 00229 (1.38), 00240 (1.30), 00252 (1.29); Milliken, W. 1064 (1.34), 1131 (1.12), 1132 (1.4)

Noerkas 433 (1.27)

Potter, D. et al. 090804-01 (1.5)

Rachmat 573 (1.38), 916 (1.15), 1002a (1); Ramlanto \& Fanani, Z. 509 (1.21), 513 (1.16); Reinwardt, C.G.C. s.n. (1.33), 1535 (1.20), 1541 (1.5), 1546 (1.23), 1571 (1.36)

Sands, M.J.S. 296 (1.9), 307 (1.30), 331 (1.35), 344 (1.9); Santika, Y. YS343 (1.4); Santoso, W. \& Rusdi WS186 (1.11), WS209 (1.21), WS256 (1.27), WS324 (1.7); Scott, S.M. 449 (1.16), 503 (1.14), 504 (1.22), 505 (1.3), 507 (1.30), 509 (1.1); Sidiyasa, K. 1369 (1.25)

Teijsmann, J.E. 5864 (1.5), 12641 (1.37); Thomas, D. \& Ardi, W.H. 08-25 (1.27), $08-26$ (1.13), 08-50 (1.5), 08-63 (1.27), 08-64 (1.27), 08-65 (1.27), 08-68 (1.5), 09-79 (1.30), 09-81 (1.30), 09-86 (1.15), 09-88 (1.29), 09-89 (1.9), 09-90 (1.9)

Unknown collector 202 (1.5), 212 (1.23), 5343 (1.23), 5562 (1.23) 
de Vogel, E.F. 2497 (1.5), 2498 (1.23), 2649 (1.16), 5097 (aff. 1.39), 5231 (1.28), 5278 (aff. 1.39), 5296

(1.16), 5315 (1.16), 5578 (1.16); de Vogel, E.F. \& Vermeulen, J.J. 6527 (1.11), 6779 (1.39), 6786

(1.16), 6829 (1.39), 6971 (1.11), 7081 (1.10), 7114 (1.5), 7202 (1.34), 7300 (1.5); de Vriese, W.H. s.n.

(1.23), 2 (1.5); de Vriese, W.H. \& Teijsmann, J.E. 2 (1.5), 24 (1.23)

Widjaja, E.A. \& Sujadi, A. EAW9051 (1.27), EAW9412 (1.39); Widjaja, E.A. et al. EAW9694 (1.5), EAW9699

(1.27), EAW9711 (cf. 1.7), EAW9712 (1.27), EAW9713 (1.16), EAW9717 (1.16), EAW9727 (1.39);

Wiriadinata, H. HW13311 (1.39), HW13371 (1.27); Wisse, C.A. 101 (1.5)

Yoshida, S. 1234 (cf. 1.7); Yusuf, R. \& Wahyono, S. 133 (cf. 1.21) 